\author{
UNIVERSIDADE DE SÃO PAULO \\ FACULDADE DE CIÊNCIAS FARMACÊUTICAS \\ Programa de Pós-Graduação em Fármaco e Medicamentos \\ Área de Insumos Farmacêuticos
}

\title{
Estudo farmacognóstico e farmacológico de Caesalpinia ferrea Martius
}

Fabiana Gaspar Gonzalez

Tese para obtenção do grau de DOUTOR

Orientador:

Profa. Assoc. Elfriede Marianne Bacchi 


\section{Fabiana Gaspar Gonzalez}

\section{Estudo farmacognóstico e farmacológico de Caesalpinia ferrea Martius}

Comissão Julgadora

da

Tese para obtenção do grau de Doutor

Prof ${ }^{a}$. Assoc. Elfriede Marianne Bacchi

Orientador/Presidente

Profa. Dra. Edna Tomiko Myiake Kato

$1^{\circ}$ examinador

Profa. Titular Silvia Berlanga de Moraes Barros

2 examinador

Profa. Dra. Clélia Akiko Hiruma Lima

$3^{\circ}$ examinador

Prof. Assoc. Luiz Claudio Di Stasi

$4^{\mathrm{o}}$ examinador

São Paulo, 06 de maio de 2005. 


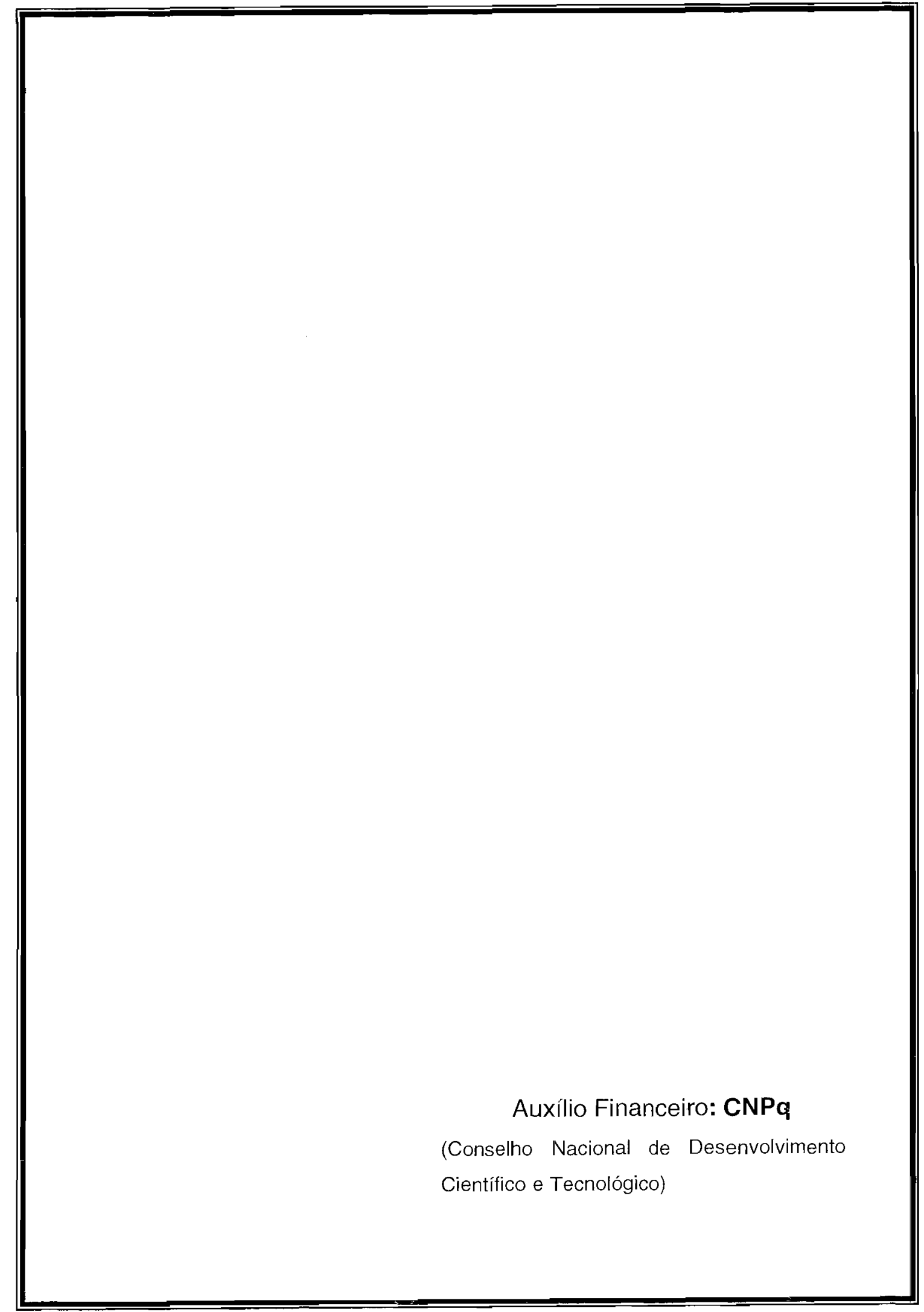


De tudo ficaram três coisas...

A certeza de que estamos começando...

A certeza de que é preciso continuar...

A certeza de que podemos ser

interrompidos antes de terminar...

Façamos da interrupção um caminho novo...

Da queda, um passo de dança...

Do medo, uma escada...

Do sonho, uma ponte...

Da procura, um encontro!

(Fernando Sabino) 
A Deus, pelo dom precioso da vida. Esta vida que recebi de presente e pela qual me sinto responsável. Obrigada por todos que entraram na minha história e me ensinaram a crescer, a ser mais gente.

Receba minha eterna gratidão.

Aos meus pais e irmãos, mistura mágica de sabedoria e afeto, que ainda hoje me dão as mãos e me ajudam a caminhar, que se desdobram por meus sonhos, que vibram comigo cada momento de minha história; a vocês dedico a minha conquista com a mais profunda admiração e respeito que me inspiram -ternos e eternoscom seus carinhos, suas dedicações, seus estímulos, seus apoios, suas compreensões, seus exemplos, $\ldots .$. 
Às grandes amigas, Raquel e Tati, vocês que compartilharam comigo meses de convivência, dias de alegria e horas de expectativas nesse nosso cotidiano, sabendo cultivar uma amizade que o tempo amadureceu, o meu eterno agradecimento.

\section{Ao Adelson,}

“...Nem mesmo o céu, nem as estrelas

Nem mesmo o mar e o infinito

Nada é maior que o meu amor

Nem mais bonito..."

Agradeço-te por todos os momentos de compreensão, carinho, amor, amizade nesta etapa tão especial da minha vida. 


\section{AGRADECIMENTOS}

Á Prof ${ }^{\mathrm{a}}$ Dr ${ }^{\mathrm{a}}$ Elfriede Marianne Bacchi, pela orientação, confiança e válidos ensinamentos.

Á Prof ${ }^{\mathrm{a}}$ Dr $^{\mathrm{a}}$ Edna Tomiko Myiake Kato, pela amizade e pela contribuição na descrição farmacobotânica.

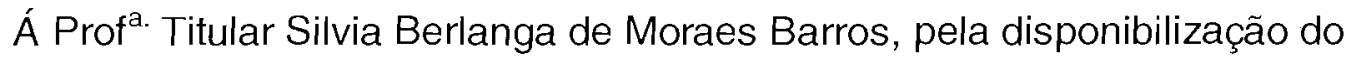
laboratório na execução de alguns modelos experimentais.

Aos funcionários do departamento de Farmacognosia, em especial, Roberto de Jesus Honório e Elisabete Claro de Souza Paiva, pelos esclarecimentos ao Iongo deste trabalho.

Ao pessoal do laboratório, em especial, Wilma, Sônia, Taís, Elisângela, André pelo agradável convívio no laboratório.

Aos meus grandes amigos (Célio, Azize, Lú Maria, Vivi, Rashi, Grau, Bozó, Fei, Dani, Karen, Paty,...), meu eterno agradecimento pela amizade e carinho sempre presentes no meu dia a dia.

Ao Luiz Claúdio Di Stasi e Clélia Akiko Hiruma Lima pela eterna arnizade, força e valiosos ensinamentos.

À Fabíola Bovo Mendonça, pela identificação da espécie vegetal.

A todos aqueles que de alguma forma contribuíram na realização deste trabalho. 


\section{Sumário}

1. INTRODUÇÃO.

.01

2. REVISÃO BIBLIOGRÁFICA .05

3. OBJETIVOS

4. MATERIAL E MÉTODOS

4.1. Material Vegetal.

4.2. Coleta

4.3. Preparo dos Extratos

4.3.1. Elaboração dos Extratos Brutos e Frações.

4.3.2. Elaboração dos Extratos Brutos enriquecidos em Flavonóides.

4.4. Descrição Macroscópica e Microscópica das Drogas Vegetais

4.4.1. Caracterização Farmacobotânica.

4.4.2. Dissociação de elementos celulares.

4.5. Análises Químicas

4.5.1. Triagem Fitoquímica.

4.5.2. Perfil Cromatográfico.

4.6. Quantificação de Taninos das Drogas Vegetais e dos Extratos Brutos Liofilizados......

4.7. Quantificação de Flavonóides das Drogas Vegetais e dos Extratos Brutos Liofilizados....35

\subsection{Ensaios Biológicos}

48.1. Avaliação da Toxicidade

DL50

Toxicidade Aguda

Toxicidade Subcrônica

4.8.2. Avaliação da Atividade Antiulcerogênica

Lesão gástrica aguda

Lesão gástrica subcrônica.

4.8.3. Avaliação da Atividade Antioxidante.

4.8.4. Avaliação da Atividade Cicatrizante 


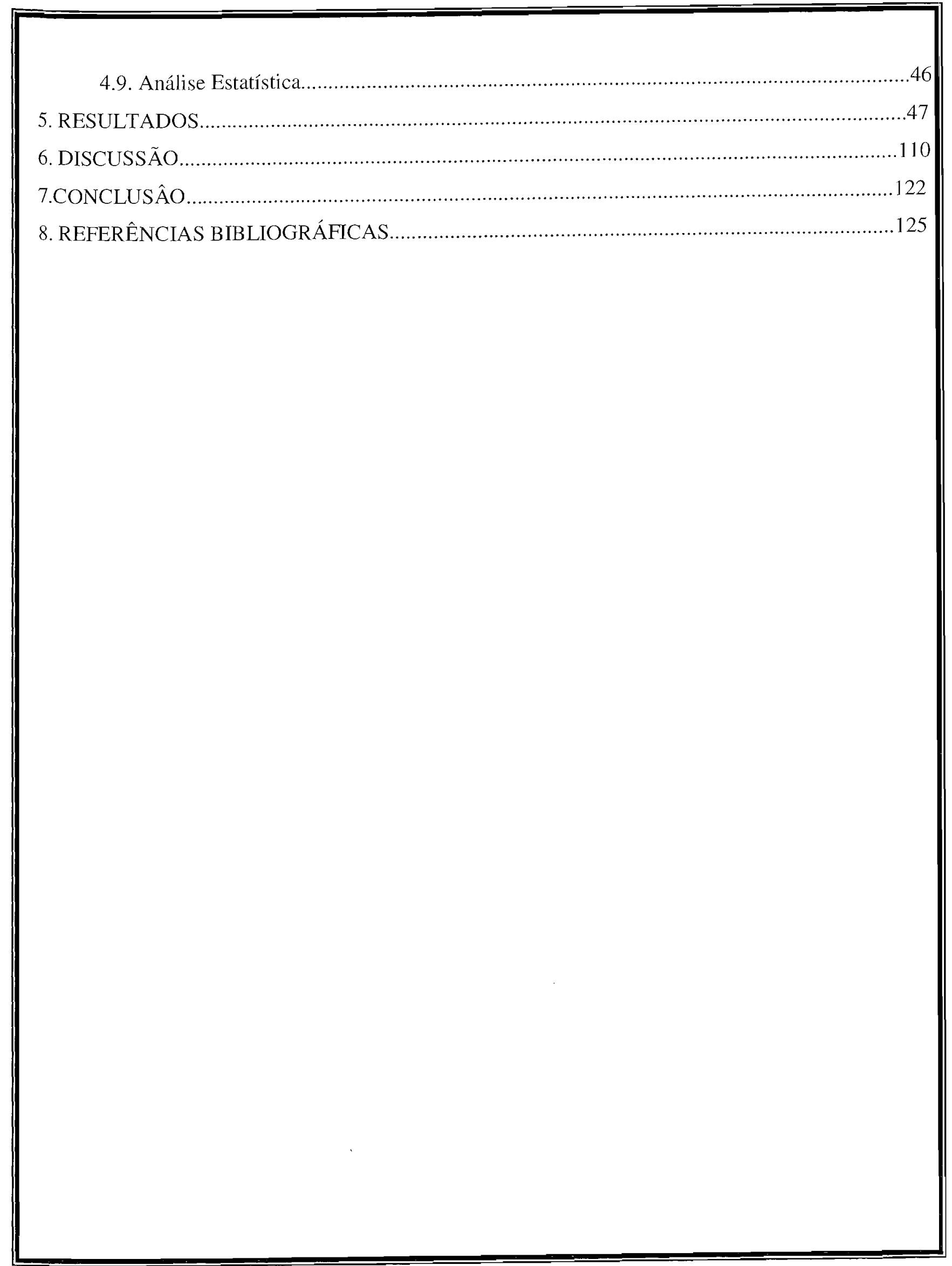




\section{Lista de Figuras}

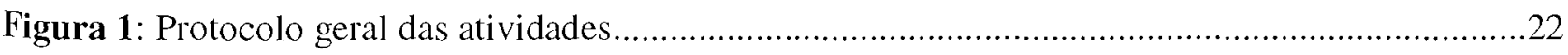

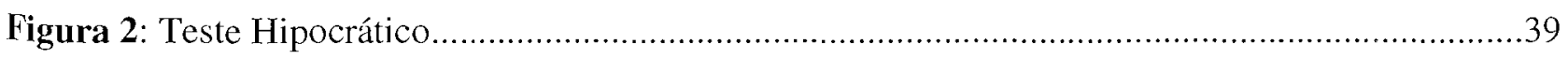

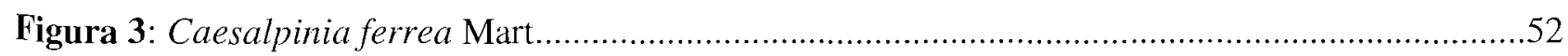

Figura 4: Caesalpinia ferrea Mart- cortes trans versais da folha (epiderme).....................................53

Figura 5: Caesalpinia ferrea Mart- cortes transversais da folha (tricoma glandular).........................54

Figura 6: Caesalpinia ferrea Mart- cortes paradérmicos e transversais da folha..................................55

Figura 7: Caesalpinia ferrea Mart- cortes transversais da folha.....................................................56

Figura 8: Caesalpinia ferrea Mart- cortes transversais da folha. Utilização de cloreto férrico na

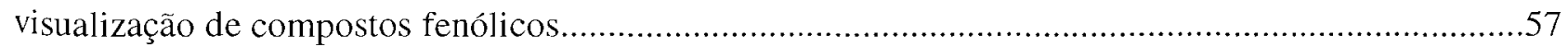

Figura 9: Caesalpinia ferrea Mart- cortes transversais de caule (súber e feloderme).........................58

Figura 10: Caesalpinia ferrea Mart. cortes transversais de caule (parênquima cortical e anel esclerenquimático)

Figura 11: Caesalpinia ferrea Mart. cortes transversais e longitudinais de caule (floema e feloderme).

Figura 12: Caesalpinia ferrea Mart. cortes transversais e longitudinais de caule (xilema).

Figura 13: Perfil Cromatográfico do EBLC e das frações clorofórmica, acetato de etila, etanólica $100 \%$ e etanólica $50 \%$ de Caesalpinia ferrea Mart.

Figura 14: Perfil Cromatográfico do EBLF e das frações clorofórmica, acetato de etila, etanólica 100\% e etanólica 50\% de Caesalpinia ferrea Mart.

Figura 15: Variação do consumo de água $(\mathrm{mL})$ dos animais fêmeas $(\mathrm{A})$ e machos (B) dos grupos Controle e Tratados (Extratos Brutos Liofilizados de Folha e Caule de C. ferrea), avaliado a cada 2 dias, durante 14 dias, no teste de toxicidade aguda, dose única, $5 \mathrm{~g} / \mathrm{kg}$, v.o.

Figura 16: Variação do consumo de ração (g) dos animais fêmeas (A) e machos (B) dos grupos Controle e Tratados (Extratos Brutos Liofilizados de Folha e Caule de C. ferrea), avaliado a cada 2 dias, durante 14 dias, no teste de toxicidade aguda, dose única, $5 \mathrm{~g} / \mathrm{kg}$, v.o.

Figura 17: Comparação entre as massas relativas de órgãos dos animais fêmeas (A) e machos (B) dos grupos Controle e Tratados (Extratos Brutos Liofilizados de Folha e Caule de C. ferrea), no teste de toxicidade aguda, dose única, $5 \mathrm{~g} / \mathrm{kg}$, v.o.... 
Figura 18: Variação do consumo de água $(\mathrm{mL})$ dos animais fêmeas $(\mathrm{A})$ e machos $(\mathrm{B})$ dos grupos Controle e Tratados (Extratos Brutos Liofilizados de Folha e Caule de C. ferrec ), avaliado a cada 2 dias, durante 33 dias, no teste de toxicidade subcrônica, nas doses diárias, $400 \mathrm{mg} / \mathrm{kg}$ e $800 \mathrm{mg} / \mathrm{kg}$, v.o.

Figura 19: Variação do consumo de ração (g) dos animais fêmeas (A) e machos (B) dos grupos Controle e Tratados (Extratos Brutos Liofilizados de Folha e Caule de C. ferrea), avaliado a cada 2 dias, durante 33 dias, no teste de toxicidade subcrônica, nas doses diárias, $400 \mathrm{mg} / \mathrm{kg} \mathrm{e} 800 \mathrm{mg} / \mathrm{kg}$, v.o.

Figura 20: Comparação entre as massas relativas de órgãos dos animais fêmeas dos grupos Controle e Tratados (Extratos Brutos Liofilizados de Folha e Caule de C. ferrea), no teste de toxicidade subcrônica, doses diárias, $400 \mathrm{mg} / \mathrm{kg}$ e $800 \mathrm{mg} / \mathrm{kg}$, v.o.

Figura 21: Comparação entre as massas relativas de órgãos dos animais machos dos grupos Controle e Tratados (Extratos Brutos Liofilizados de Folha e Caule de C. ferrea), no teste de toxicidade subcrônica, doses diárias, $400 \mathrm{mg} / \mathrm{kg}$ e $800 \mathrm{mg} / \mathrm{kg}$, v.o.....

Figura 22: Efeito dos Extratos Brutos Liofilizados de Folha e Caule de C. ferrea, $400 \mathrm{mg} / \mathrm{kg}$, v.o., no modelo de indução gástrica pelo Etanol $(60 \%) / \mathrm{HCl}(0.3 \mathrm{M}), 1 \mathrm{~mL} / 100 \mathrm{~g}$ (v.o.)......

Figura 23: Efeito dos Extratos Brutos Liofilizados de Folha e Caule de C. ferrea enriquecidos em flavonóides, $400 \mathrm{mg} / \mathrm{kg}$, v.o., no modelo de indução gástrica pelo Etanol $(60 \%) / \mathrm{HCl}(0.3 \mathrm{M}), 1 \mathrm{~mL} / 100 \mathrm{~g}$ (v.o.).

Figura 24: Efeito d as frações clorofórmica, acetato de etila, etanólica 100\% e etanólica 50\% de folha de C. ferrea, 400mg/kg, v.o., no modelo de indução gástrica pelo Etanol (60\%)/HCl (0.3M), 1mL/100g (v.o.)

Figura 25: Efeito d as frações clorofórmica, acetato de etila, etanólica 100\% e etanólica 50\% de caule de C. ferrea, $400 \mathrm{mg} / \mathrm{kg}$, v.o., no modelo de indução gástrica pelo Etanol (60\%)/HCl (0.3M), $1 \mathrm{~mL} / 100 \mathrm{~g}$, v.o.)...

Figura 26: Efeito dos Extratos Brutos Liofilizados de Folha e Caule de C. ferrea, 200mg/kg, v.o., no modelo de indução gástrica pelo Ácido Acético $30 \%$.

Figura 27: Efeito dos Extratos Brutos Liofilizados de Folha e Caule de C. ferrea, $400 \mathrm{mg} / \mathrm{kg}$, v.o., no modelo de indução gástrica pelo Ácido Acético $30 \%$.

Figura 28: Capacidade antioxidante $(\mathrm{CAOx} \%)$ dos Extratos brutos liofilizados de caule e folha de C. ferrea, na lipoperoxidação de homogenato de cérebro de ratos. 
Figura 29: Regressão linear na Capacidade Antioxidante dos Extratos Brutos Liofilizados de Folha e Caule de C. ferrea.

Figura 30: Efeito dos Extratos brutos liofilizados de caule e folha de C. ferreaa, $15 \%$ em água, via tópica, no modelo de atividade cicatrizante.

Figura 31: Fotomicrografia de corte histológico de pele de animal controle, com 15 dias de evolução, mostrando reparação epitelial, com formação de epitélio pavimentoso estratificado queratinizado. $\mathrm{Na}$ derme subjacente, nota-se reparação por cicatrização. Coloração: hematoxilina-eosina (HE).

Aumento:40x

Figura 32: Detalhe em maior aumento da fotomicrografia anterior, evidenciando o epitélio regenerado e a área de reparação, com escasse $\iota$ de fibroblastos, alguns fibrócitos e grande quantidade de colágeno.

Nota-se resquícios de vasos neoformados. Coloração: HE. Aumento: 100x.

Figura 33: Fotomicrografia de corte histológico de pele de rato tratado com extrato de caule, com 15 dias de evolução, mostrando falta de regeneração epitelial, derme subjacente com vasos neoformados, alta celularidade e colágeno desorganizado. Coloração: HE. Aumento:4x.

Figura 34: Fotomicrografia de corte histológico de pele de animal tratado com extrato de caule, com 15 dias de evolução, mostrando tentativa de regeneração epitelial. Na derme subjacente, nota-se tecido de granulação, com grande quantidade de vasos neoformados, fibroblastos, fibrócitos e colágeno desorganizado. Coloração: HE. Aumento: 100x

Figura 35: Fotomicrografia de corte histológico de pele de rato, tratado com extrato de folha, com 15 dias de evolução, mostrando ausência de regeneração epitelial. Na derme subjacente, nota-se tecido de granulação com escassez de colágeno. Coloração: HE. Aumento: 4x.......

Figura 36: Detalhe em maior aumento da fotomicrografia anterior, evidenciando tecido de granulação com exuberância de vasos neoformados, grande quantidade de fibroblastos. Na superfície, à direita, nota-se ausência de regeneração epitelial. Coloração: HE. Aumento: 100x. 104

Figura 37: Fotomicrografias de cortes histológicos de pele de animal controle com 15 dias de evolução A) corado pelo Picro sírius, evidenciando colágeno. B) corado com Picro sírius em luz polarizada, destacando o colágeno da área de reparação por cicatrização. Aumento: 40x. 105

Figura 38: Fotomicrografia de corte histológico de pele de rato tratado com extrato de caule com 15 dias de evolução A) corado pelo Picro sírius, evidenciando colágeno. B) corado com Picro sírius em luz polarizada, destacando o colágeno. Aumento: 40x. 
Figura 39: Fotomicrografia de corte histológico de pele de rato tratado com extrato de folha com 15 dias de evolução A) corado pelo Picro sírius, mostrando quantidade escassa de colágeno na área de reparação. B) corado com Picro sírius em luz polarizada, mostrando pequena quantidade de colágeno na área de reparação. Aumento: 40x 


\section{Lista de Tabelas}

Tabela 1: Composição química e atividades farmacológicas de espécies pertencentes ao gênero Caesalpinia.

Tabela 2: Triagem fitoquímica de Caesalpinia ferrea Mart. -Testes realizados com o pó das drogas e Extratos Brutos Liofilizados de Folha (EBLF) e Caule (EBLC).

Tabela 3: Teor de Taninos (\%)nas drogas vegetais de caule e de folha de Caesalpinia ferrea Mart e nos seus respectivos extratos brutos liofilizados.

Tabela 4: Teor de Flavonóides nas drogas vegetais de caule e de folha de Caesalpinia ferrea Mart e nos seus respectivos extratos brutos liofilizados

Tabela 5: $\mathrm{DL}_{50}$ do Extrato Bruto Liofilizado de Folha (EBLF) de C. ferrea, administrado, por via oral, nas doses de $1538,2461,3938,6300$ e $10.080 \mathrm{mg} / \mathrm{kg}$.

Tabela 6: Determinação dos parâmetros Hematológicos dos animais fêmeas e machos submetidos à Avaliação Toxicidade Subcrônica dos extratos brutos liofilizados de folha e caule de Caesalpinia ferrea, nas doses de 400 e $800 \mathrm{mg} / \mathrm{kg}$, v.o., durante 33 dias

Tabela 7: Determinação dos parâmetros Bioquímicos dos animais fêmeas e machos submetidos à Avaliação da Toxicidade Subcrônica dos extratos brutos liofilizados de folha e caule de Caesalpinia ferrea, nas doses de 400 e $800 \mathrm{mg} / \mathrm{kg}$, v.o., durante 33 dias.

Tabela 8: Capacidade Antioxidante (CAOx\%) dos Extratos Brutos Liofilizados de Folha (EBLF) e Caule (EBLC) de $C$. ferrea na lipoperoxidação de homogenato de cérebro de rato.

Tabela 9: Cálculo de $\mathrm{Q}_{1 / 2}$ (Concentração necessária para atingir 50\% da Capacidade Antioxidante) dos Extratos Brutos Liofilizados de Folha (EBLF) e Caule (EBLC) de C. ferrea na lipoperoxidação de homogenato de cérebro de rato. 


\section{Estudo farmacognóstico e farmacológico de Caesalpinia ferrea Martius.}

Caesalpinia ferrea Martius, popularmente conhecida como pau-ferro e jucá, é utilizada na medicina tradicional para o tratamento de problemas hepáticos, respiratórios e, em especial, para distúrbios gastrintestinais e como cicatrizante. Deste modo, os objetivos do presente trabalho visaram avaliar os extratos brutos liofilizados de folha (EBLF) e caule (EBLC) quanto a caracterização botânica, o estudo químico e farmacológico, direcionando principalmente, às ações antiúlcera, antioxidante e cicatrizante, e toxicidade destes órgãos vegetais de $C$. ferrea.

A triagem fitoquímica foi realizada com a droga vegetal constituída de folha (DF) e de caule (DC), bem como com os seus EBLF e EBLC. Os métodos empregados foram preconizados por Farnsworth (1966) e Matos (1988) onde foram pesquisados os seguintes compostos: flavonóides, glicósidos cardiotônicos, saponinas, antraderivados, alcalóides, cumarinas, taninos e óleo essencial. Além disso, foi realizada a quantificação de taninos e flavonóides segundo a metodologia proposta na Farmacopéia Européia (2001) e na Farmacopéia Brasileira (2003), respectivamente. Para a avaliação da Toxicidade de $C$. ferrea foram realizadas a Toxicidade Aguda de ambos os órgãos vegetais, a DL $_{50}$ do EBLF e a Toxicidade subcrônica do EBLF e EBLC, todos os modelos seguiram a metodologia de Brito (1994). Para análise da atividade antiulcerogênica da espécie em estudo foi realizado o teste da indução de lesão gástrica aguda por etanol/HCl e lesão subcrônica por ácido acético. Grupos Tratados receberam EBLF ou EBLC ou frações ou extratos enriquecidos em flavonóides, Grupo Controle água ou tween 80 e Grupo de Referência Misoprostol ou Cimetidina. Três parâmetros foram avaliados neste modelo: Área Total de Lesão (ATL), Área Relativa de Lesão (ARL) e Índice de Lesão Ulcerativa (ILU). A atividade antioxidante "in vitro" foi medida através da inibição da autoxidação de homogenato de cérebro de Ratos (Stocks et al., 1974).

Os extratos foram solubilizados em etanol $70 \%$ e as diluições 10.05 $0.003 \mathrm{mg} / \mathrm{mL}$ ) foram efetuadas em etanol $35 \%$. O etanol $35 \%$ foi utilizado como controle. E na avaliação da Atividade Cicatrizante, os animais (ratos) sofreram uma incisão na região dorsal com auxílio de punch. Os Grupos Tratados receberam diariamente $1 \mathrm{~mL}$ de EBLF ou EBLC, solubilizados a $15 \%$ em água, e o Grupo Controle água destilada na mesma proporção por um período de 14 dias.

$\mathrm{Na}$ triagem fitoquímica foram detectados para ambos os extratos, flavonóides, taninos, além de antraderivados e cumarinas nas Folhas. A porcentagem encontrada 
de Taninos na DF foi de $7.13 \%$ e no EBLF de $23.95 \%$ e na DC foi de $2.26 \%$ e no EBLC de $11.77 \%$. Já a quantificação de flavonóides foi de $0.0095 \%$ na DF, $0.026 \%$ no EBLF, $0.00014 \%$ na DC e de $0.0017 \%$ no EBLC.

No teste de toxicidade aguda, somente os animais que receberam EBLF apresentaram alterações comportamentais a partir dos primeiros tempos de observação e morte de 3 animais machos e 2 fêmeas ( $n=5 /$ sexo). Dessa forma, a $D L_{50}$ encontrada para este extrato vegetal foi de $5471.64 \mathrm{mg} / \mathrm{Kg}$ para as fêmeas e de $3112.94 \mathrm{mg} / \mathrm{Kg}$ para os machos. Na Toxicidade subcrônica, apenas os animais fêmeas que receberam EBLC $(800 \mathrm{mg} / \mathrm{Kg})$ apresentaram uma diferença significativa, em relação ao grupo controle, quanto ao peso do rim, porém não foi encontrada nenhuma alteração histológica neste órgão.

EBLF e EBLC apresentaram significativa atividade antiulcerogênica no modelo de lesão gástrica aguda dentro dos parâmetros avaliados. O EBLC reduziu em $37 \%$ a ARL. Já o EBLF foi tão ativo como o Misoprostol reduzindo em 95\%, 81\% e $63 \%$ a ATL, a ARL e o ILU, respectivamente contra $92 \%, 70 \%$ e $59 \%$ do fármaco de referência. Porém, as frações e os extratos enriquecidos em flavonóides obtidos de ambos os extratos brutos liofilizados não apresentaram atividade antiulcerogênica em nenhum dos 3 parâmetros. Esses mesmos resultados foram obtidos no modelo de lesão gástrica subcrônica para ambos os extratos vegetais. Os EBLF e EBLC de $C$. ferrea promoveram uma atividade antioxidante de $94 \%$ e $84 \%$, respectivamente, na concentração de $0.8196 \mu \mathrm{g} / \mathrm{mL}$, e um $Q_{1 / 2}$ de 0.2331 (Folha) e 0.5061 (Caule) $\mu \mathrm{g} / \mathrm{mL}$.

$\mathrm{Na}$ avaliação da atividade cicatrizante de ambos os extratos vegetais, não foi encontrada diferença significativa entre os Grupos Tratados e Controle. No laudo histológico não se observou nenhum sinal de cicatrização tecidual. Apesar de $C$. ferrea ser utilizada pela população como cicatrizante, não foi possível confirmar tal atividade nas folhas e nos caules desta espécie. 


\section{Pharmacognostic and Pharmacologic study of Caesalpinia ferrea Mart.}

Caesalpinia ferrea Martius, populary, known as iron-wood or juca, is utilized in traditional medicine in the treatment of both hepatic and respiratory problems and, in special, for gastrointestinals disturbances and eventual healing. The objective of the present work is to evaluate the leiophyllized brute extracts of the leaf (LBEL) and the stem (LBES), the botanic caracterization, the chemical and pharmacological studies, focuzing principally, the antiulcer and healing action, and also the toxicity of these vegetable organs of $C$. ferrea.

The phytochemical was made with the drug of the leaf (DL) and of the stem (DS)- LBEL and LBES. The method was precognized by Farnsworth (1966) e Matos (1988) where doing research of: flavonoids, cardiotonic glicosids, saponins, antraderivates, alkaloids, coumarins, tannins and essential oil. Beyond that, the quantification of tannins and flavonoids according to the metodology proposed in European Pharmacopeia (2001) and Brazilian Pharmacopeia (2003) were also undertaken, respectively. For the evaluation of the $C$. ferrea toxicity, the acute toxicity of both vegetable organs, the $\mathrm{DL}_{50}$ of LBEL and the subcronical toxicity of LBEL and LBES, were analyzed following the metodology of Brito (1994). The test of induction of acute gastric lesion for ethanol/ $\mathrm{HCl}$ was used for antiulcerogenic activity analysis of the species studied. Treated Groups received LBEL or LBES or fractions or extracts enrich in flavonoids, Controls Groups water or tween 80 and misoprostol Reference Group. Three parameters were evaluated considering: Total Area of Lesion (TAL), Relative Area of Lesion (RAL) and Rate of Ulcerative Lesion (RUL). And for evaluation of subcronic gastric lesion by acetic acid $30 \%$, the Treated Group received LBEL or LBES, Control Group water and cimetidine Reference Group. The ulcerative lesions were evaluated only in 2 parameters: RAL and RUL. An antioxidant activity "in vitro" was measured through inibition of antioxidation of homogenate of rat brain (Stocks et al., 1974). The extracts were solubilized in ethanol $70 \%$ and dilutions (0.05$0.003 \mathrm{mg} / \mathrm{mL}$ ) were performed in ethanol $35 \%$. The ethanol $35 \%$ was utilized like control. And for evaluation of healing activity, the aninals (rats) suffered na incision in the dorsal region with a punch aid. The Treated Groups received daily $1 \mathrm{~mL}$ of LBEL or LBES, solubilized by $15 \%$ in water, and Control Group distilled in the same proportion during a 14 day period.

In phytochemical were detected for both extacts, flavonoids, tannins., beyond antradderivate and coumarins in leaves. The percentages of tannins found were $7.13 \%$ in DL, $23.95 \%$ in LBEL, $2.26 \%$ in DS and $11.77 \%$ in LBES. The quantification of 
flavonoids was $0.0095 \%$ in DL, $0.026 \%$ in LBEL, $0.00014 \%$ in DS and $0.0017 \%$ in LBES.

During the acute toxicity test, it was observed a behaviour alteration among animals that received LBEL up tp the first time of observation and death pof 3 males and 2 females. The $D L_{50}$ found to this vegetable extract was $5471.64 \mathrm{mg} / \mathrm{Kg}$ for the females and $3112.94 \mathrm{mg} / \mathrm{Kg}$ for the males. In subronic toxicity, only the females receiving LBES $(800 \mathrm{mg} / \mathrm{Kg})$ presented a significant difference, according to the Control Group, as much as the weight of a kidney. However, no histologic alteration in this organ was found.

LBEL and LBES presented antiulcerogenic significant activity in acute gstric lesions, based on the parameters evaluated. The LBES was reduced to $37 \%$ in RAL. The LBEL was so active as the misoprostol, being reducid to $95 \%, 81 \%$ and $63 \% \mathrm{TAL}$, RAL and the RUL, respectively against $92 \%, 70 \%$ and $59 \%$ of pharmaco of reference. Nevertheless, nor the fractions nor the flavonoids enriched extracts obtained from both leiophyllized brute extracts showed antiulcerogenic activity at the 3 studied parameters. Up to the present time, in model subcronic gastric lesion, none of both vegetable extracts in question has showed active similar to TAL, RAL and RUL in relation to the Control Group. The LBEL and LBES of $C$. ferrea promoved an antioxidant activity of $93,56 \%$ and $84,38 \%$, respectively, in concentration of de $0.8196 \mu \mathrm{g} / \mathrm{mL}$, and a $Q_{1 / 2}$ of 0.2331 (Leaf) and 0.5061 (Stem) $\mu \mathrm{g} / \mathrm{mL}$.

Concernirig the healing activity evaluation of both vegetable extracts, no significant differences between Treats and Control Groups were found. Also in histologic award, no sign of tecidual cicatnzation was observed. In spite of the fact that C. ferrea has been utilized by the population as cicatrizant, no clear evidence of its leaves and stems healing activity has been confirmed. 


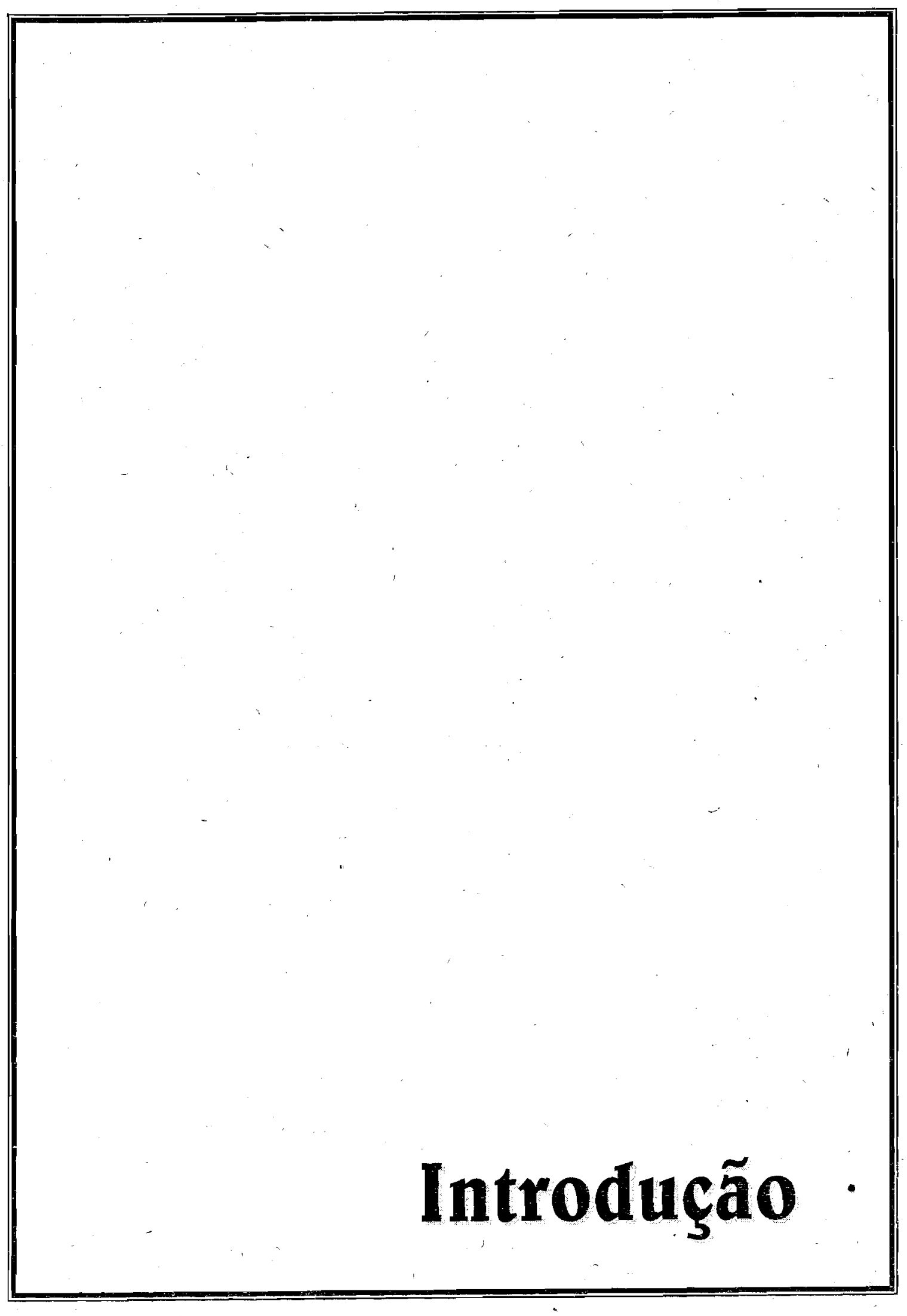




\section{Introdução}

Os vegetais apresentam um importante papel na cultura dos povos, sendo empregados com diferentes finalidades, seja como fonte de alimentos, materiais para vestuários, habitação, utilidades domésticas, utensílios para manifestações artísticas, culturais e religiosas e como meio restaurador da saúde. Sua importância pode ser medida não apenas pela variedade de empregos, mas também, pela intensidade de seus usos. Os vegetais representam uma das alternativas entre as diversas fontes de insumos necessários à existência da sociedade, tendo como principal vantagem o fato de serem uma fonte renovável (Schenkel et al., 2003a), podendo atender aos diversos interesses das sociedades.

Em especial podemos destacar a importância das plantas como matériaprima para a obtenção de novos medicamentos, seja como um fitoterápico padronizado ou como fonte de novos fármacos com fins terapêuticos. Segundo a OMS, cerca de $80 \%$ da população mundial, residente em países subdesenvolvidos, faz uso de plantas medicinais como o único lenitivo para suas necessidades básicas de saúde. No Brasil, o consumo de medicamentos está restrito a cerca de $30 \%$ da população economicamente privilegiada, sendo considerado entre o $4^{\circ}$ ou $5^{\circ}$ mercado consumidor de medicamentos industrializados em âmbito mundial (A Guerra..., 1997); o que também nos fornece uma idéia do quanto inacessível os medicamentos são à maioria da população.

Nos Estados Unidos, as vendas de medicamentos antiulcerogênicos em 1992 correspondeu a cerca de 4 bilhões de dólares (Alper, 1993), indicando a alta freqüência dessa patologia, sendo que esse quadro se repete em diversos países, assim como no Brasil. Mediante essa situação, o estudo de plantas medicinais, bem como a padronização de fitoterápicos, tornam-se necessários, já que esses recursos naturais são uma alternativa mais acessível à maior parte da população, tanto para o tratamento de úlceras gástricas como para as demais patologias. 
Todavia, a incorporação desses remédios tradicionais nos sistemas básicos de saúde requer determinação precisa de eficácia e toxicidade, métodos de controle de qualidade, além da padronização local de produção e uso (Jaroszewski, 1984). Tais requerimentos tornam-se de maior importância em países como o Brasil, onde a maioria das espécies vegetais de valor medicinal ainda não foi estudada, especialmente as nativas encontradas nos diferentes ecossistemas brasileiros.

Em função do exposto, decidimos estudar Caesalpinia ferrea (pau-ferro, jucá, ibirá-obi, imirá-itá, muirá-obi e muiré-itá), espécie que vem sendo muito utilizada na medicina tradicional como cicatrizante e, principalmente, no tratamento de úlceras gastrintestinais (Di Stasi, Hiruma- Lima et al, 2002). Na região da Amazônia e Vale do Ribeira, vários são os usos medicinais desta espécie; as folhas, por exemplo, são utilizadas externamente, contra hemorróidas, enquanto que o uso interno desta é útil contra amebíase e problemas hepáticos, além de ser usado como fortificante para crianças. A infusão conjunta das folhas e frutos é útil para tratar inflamações hepáticas e tuberculose, enquanto que a decocção da casca é usada internamente como anti-disentérica. O preparado da casca com 1 litro de água e $1 \mathrm{~kg}$ de açúcar, aquecido até formar um xarope, é utilizado contra asma e bronquite. A infusão corjunta da raspa da casca com folha de manga é útil como antigripal e antitussígeno, enquanto que o preparado de casca de jucá, casca de jatobá, folha de manga, açúcar e água, após aquecimento, é utilizado como anti-catarral. A vagem crua é útil contra tosse, inflamações hepáticas, baço, desarranjo menstrual e problemas renais e pulmonares (Di Stasi, Hiruma- Lima et al, 2002).

Outros usos medicinais desta espécie são referidos por alguns autores, tais como contra feridas e contusões no Piauí (Emperaire, 1982 apud Di Stasi, Hiruma- Lima et al., 2002) e contra tosse crônica, asma e como cicatrizante em Alagoas (Carnpêlo, 1982 apud Di Stasi, Hiruma- Lima et al., 2002), além do uso das raízes como febrífugas e anti-diarreicas; do fruto com propriedades anti-diabéticas; da casca como desobstruente e da madeira como anti-catarral e contra feridas (Corrêa, 1984). Frente a esses inúmeros usos populares, é de fundamental importância um estudo sobre a comprovação de sua(s) 
atividade(s), bem como de sua inocuidade e controle de qualidade da droga vegetal. 


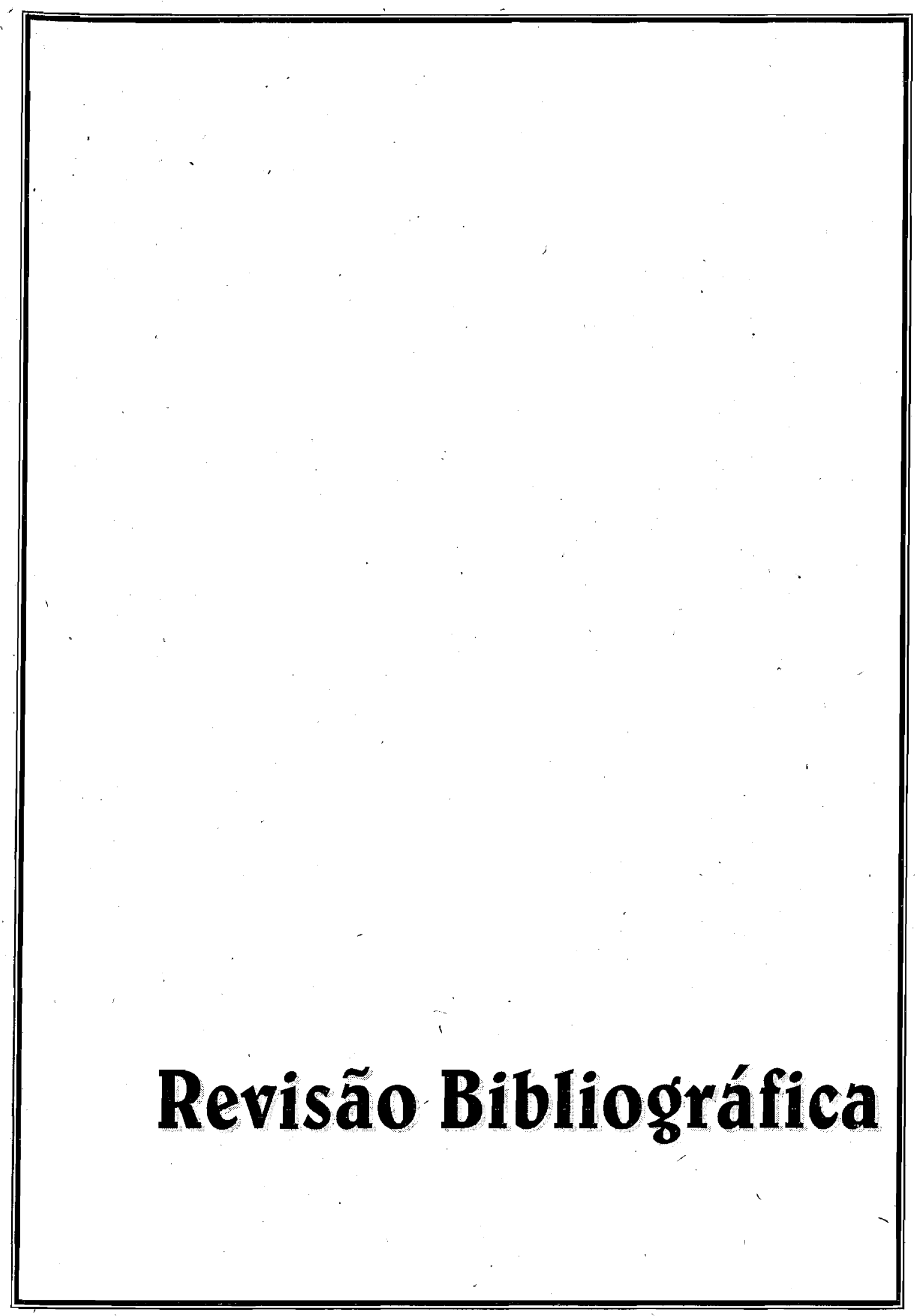




\section{Revisão Bibliográfica}

O levantamento Bibliográfico encontra-se dividido nos ítens seguintes: estudos botânicos, químicos e farmacológicos da família Leguminosae, do gênero Caesalpinia e da espécie Caesalpinia ferrea.

\section{1- Aspectos Botânicos}

Leguminosae (Fabaceae), originalmente descrita por Antoine Laurent de Jussieu, inclui 642 gêneros e cerca de 18.000 espécies cosmopolitas. Inclui desde árvores, arbustos até lianas e ervas (Di Stasi, Hiruma-Lima et al., 2002). Comumente é dividida em 3 subfamilias: Caesalpinioideae, Mimosoideae e Faboideae (Papilionoideae) (Joly, 1966; Hutchinson,1964; Takhtadzhian, 1997).

Hutchinson (1964) observando que os caracteres dos 3 taxa interpenetram-se, considera conveniente mantê-los na categoria de subfamílias. O mesmo autor em 1969, passa a tratar os 3 taxa como familias pertencentes à ordem Fabales ou Leguminales (Caesalpiniaceae, Fabaceae e Mimosaceae), assim como Taktajan (1969) igualmente elevou os 3 taxa à categoria de família.

Segundo Robertson e Lee (1976), as 3 subfamílias que compreendem Leguminosae são grupos naturais. Entretanto, há divergências quanto à categoria a ser dada aos respectivos taxa.

A espécie empregada no estudo foi identificada como Caesalpinia ferrea Martius, Leguminosae-Caesalpinoideae, sendo esta a terminologia empregada ao longo do texto.

A subfamília Caesalpinoideae compreende cerca de 180 gêneros e 2500 a 3000 espécies distribuídas em regiões tropicais e subtropicais. Embora a subfamília seja bem representada no Brasil, a maior parte das espécies ocorre na África, América e sudeste da Ásia (Ribeiro et al., 1999).

Esta subfamília inclui diversos representantes de importância medicinal pertencentes aos gêneros Caesalpinia, Cassia, Dimorphandra, Hymenaea, Bauhinia, Copaifera e Senna (Di Stasi e Hiruma-Lima, et al., 2002). São plantas 
arbóreas, arbustivas, subarbustivas, trepadeiras de matas, raramente são ervas (Joly, 1966).

As folhas são alternas, compostas, pari a imparipinadas ou bipinadas; os folíolos são opostos ou subopostos, com pulvinos. As inflorescências podem ser racemo, panículas ou espigas, terminais ou axilares. As flores são vistosas, geralmente hermafroditas, zigomorfas e pentâmeras; a pétala superior é geralmente interna em relação às duas laterais. Os frutos são geralmente do tipo legume. As sementes apresentam, às vezes, arilo, tegumento duro e impermeável. A polinização ocorre com auxilio de insetos, morcegos e beijaflores e a dispersão, através de animais, água e vento. (Metcalfe e Chalk, 1964; Joly, 1966, Ribeiro et al., 1999).

Sob o aspecto anatômico, as folhas podem apresentar tricomas glandulares e tectores. Epiderme papilosa ou sub-papilosa é observada em espécies de Apuleia, Bauhinia, Caesalpinia, Cassia, Crudia, Cynometra, Delonix, Detarium, Dialium, Dicorynia, Dimorphandra, Hardwickia (somente em uma das faces), Labichea, Macrolobium, Peltophorum, Pterolobium, Schizolobium, Scorodophloeus, Wagatea. Mucilagem foi detectada nas espécies de Caesalpinia, Cassia, Cercidium, Cercis, Crudia, Dialium, Dimorphandra, Haematoxylon, Hoffmanseggia, Peltophorum, Scorodophloeus. As folhas são hipoestomáticas, mas podem apresentar-se anfiestomáticas como em Caesalpinia, Cassia, Cercidium, Erythophleum (somente em uma espécie). A disposição das células subsidiárias é variável entre as espécies. Drusas, freqüentemente observadas no mesofilo, são descritas também em Apuleia e Eperua, e cristais isolados e agrupados em Saraca triandra Bak. O mesofilo apresenta feixes vasculares freqüentemente acompanhados de esclerênquima em Afzelia, Berlinia, Caesalpinia, Cassia, Cercidium, Cercis, Dialium, Dimorphandra, Crudia, Cynometra, Delonix. Estruturas secretoras de diversos tipos podem ocorrer, porém a natureza química da secreção não está determinada (Metcalfe \& Chalk, 1964; Joly, 1966).

Estudos de anatomia de cascas de Caesalpinoideae são raros. Em Cassia e Ceratonia as células do súber são cúbicas, em Gleditschia e Tamarindus apresentam-se achatadas e, em Bauhinia e Gymnocladus esta forma é menos acentuada (Metcalfe \& Chalk, 1964). O periciclo do caule jovem quase sempre é representado por um anel contínuo de esclereídes ou de 
fibras, exceto em Bauhinia. Esse periciclo é freqüentemente acompanhado externamente por uma bainha cristalífera. O floema geralmente mostra cristais isolados, muitas vezes, acompanhados de drusas. Em Brownea coccinea Jacq. e Tamarindus indica Linn o floema secundário evidencia fibras. Em Cassia grandis Linn. o floema secundário apresenta floema estratificado contendo cristais isolados, ocasionalmente acompanhados por drusas. O lenho forma cilindro contínuo separado normalmente por raios estreitos. Vasos com pontoações simples são observados. Apresenta vasos de tamanho mediano

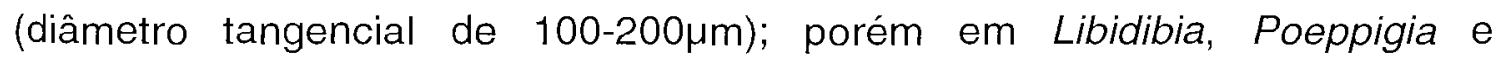
Zuccagnia estes são muito pequenos $(25-50 \mu \mathrm{m})$, em Apuleia, Baikiaea, Caesalpinia, Cercidium, Copaifera mopane Kirk., Cynometra alexandri C. H. Wright, Etaballia, Holocalyx, Parkinsonia, Peltogyne são moderadamente

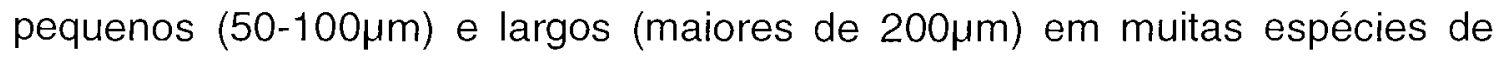
Abauria, Acrocarpus, Afzalia, Aldina, Berlinia, Cassia, Cordyla, Daniella, Detarium, Dialium, Dinizia, Eperua, Erythrophelum, Koompassia, Mora, Peltophorum e Sclerolobium. Tipicamente solitários com alguns múltiplos de 2 ou 3 células e alguns aglomerados irregulares, geralmente de pequenas células, nem sempre presente em todas as seções, múltiplos radiais mais comuns e às vezes de 4 ou mais células (Metcalfe e Chalk, 1964). O parênquima freqüentemente abundante, mostra-se tipicamente paratraqueal. Localiza-se em bandas confluentes irregulares ou, na maioria dos gêneros, em bandas cortínuas regulares. Cavidades secretoras de óleo ocorrem em córtex primário de Copaifera spp., e alongadas, na mesma posição, em espécies de Caesalpinia, Daniella, Detarium, Hardwickia, Kingiodendron, Oxystigma e Schotia. Também foram registradas tais cavidades, no parênquima medular e/ou periciclo, de Detarium, Erythrophloeum densiflorum (Elm.) Merr., mas de acordo com Planchon (1729, apud Joly, 1966) essas estruturas não estão presentes em outras espécies de Erythrophloeum e Hardwickia.

\section{2- Aspectos Químicos e Farmacológicos}




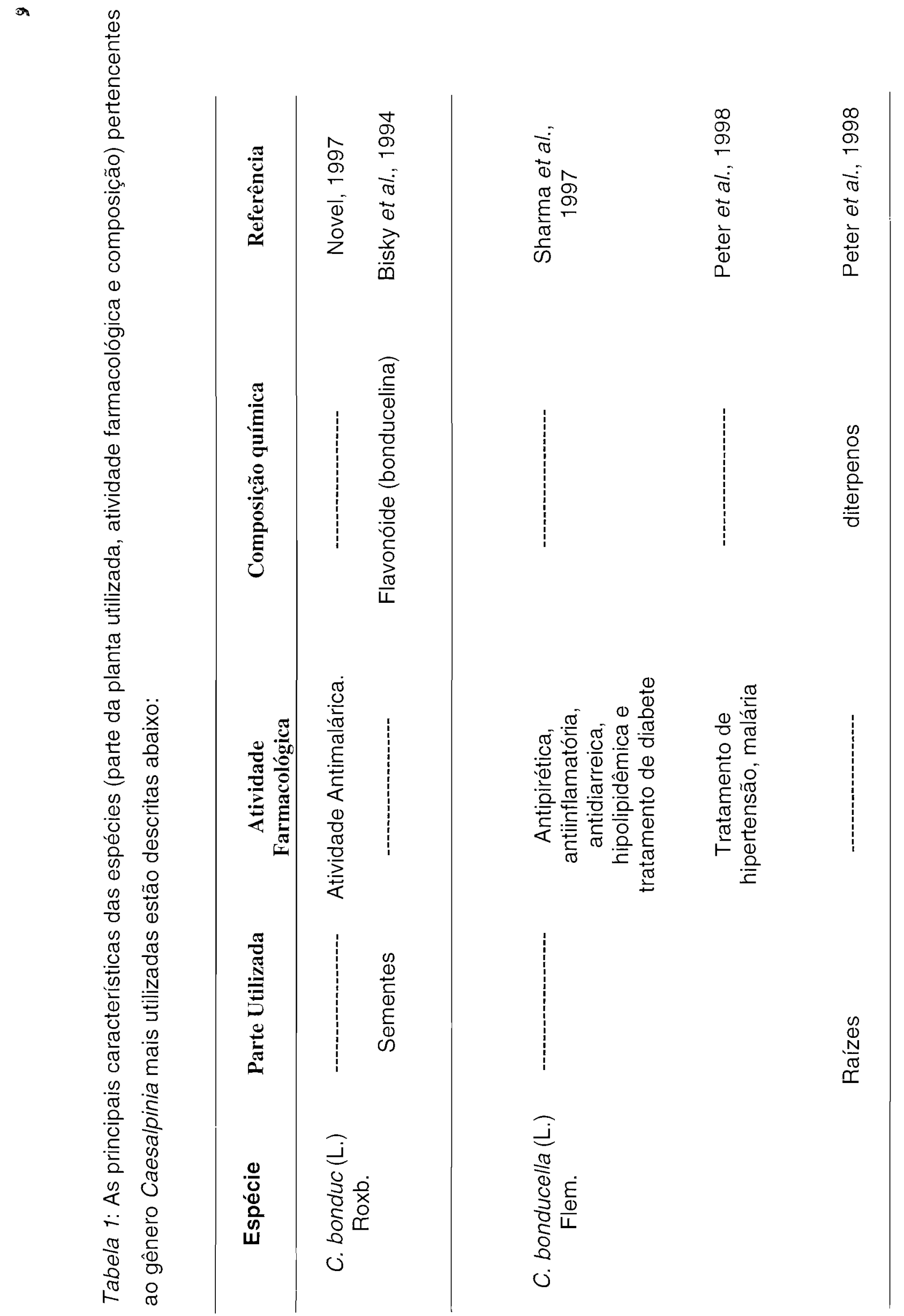




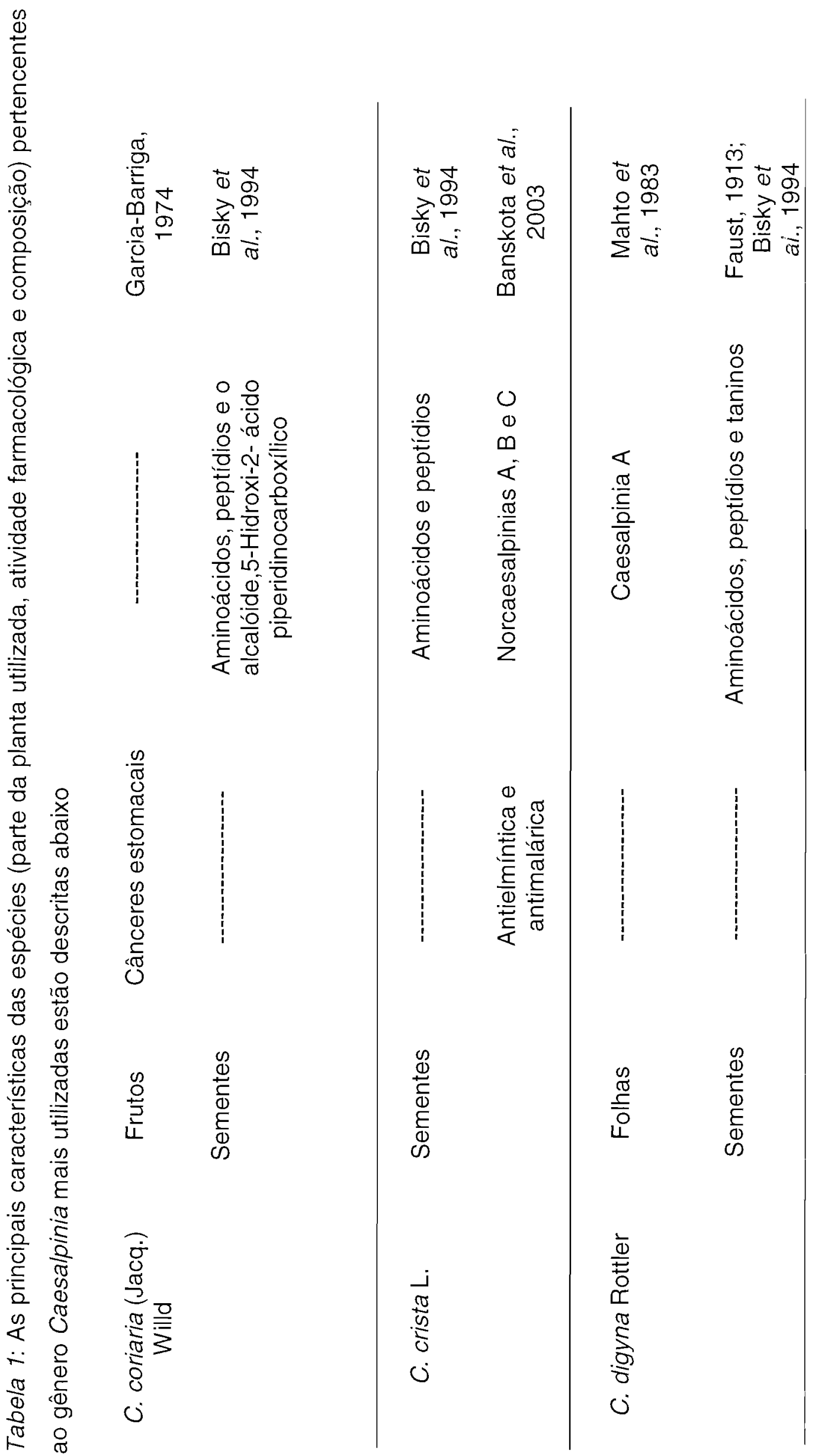




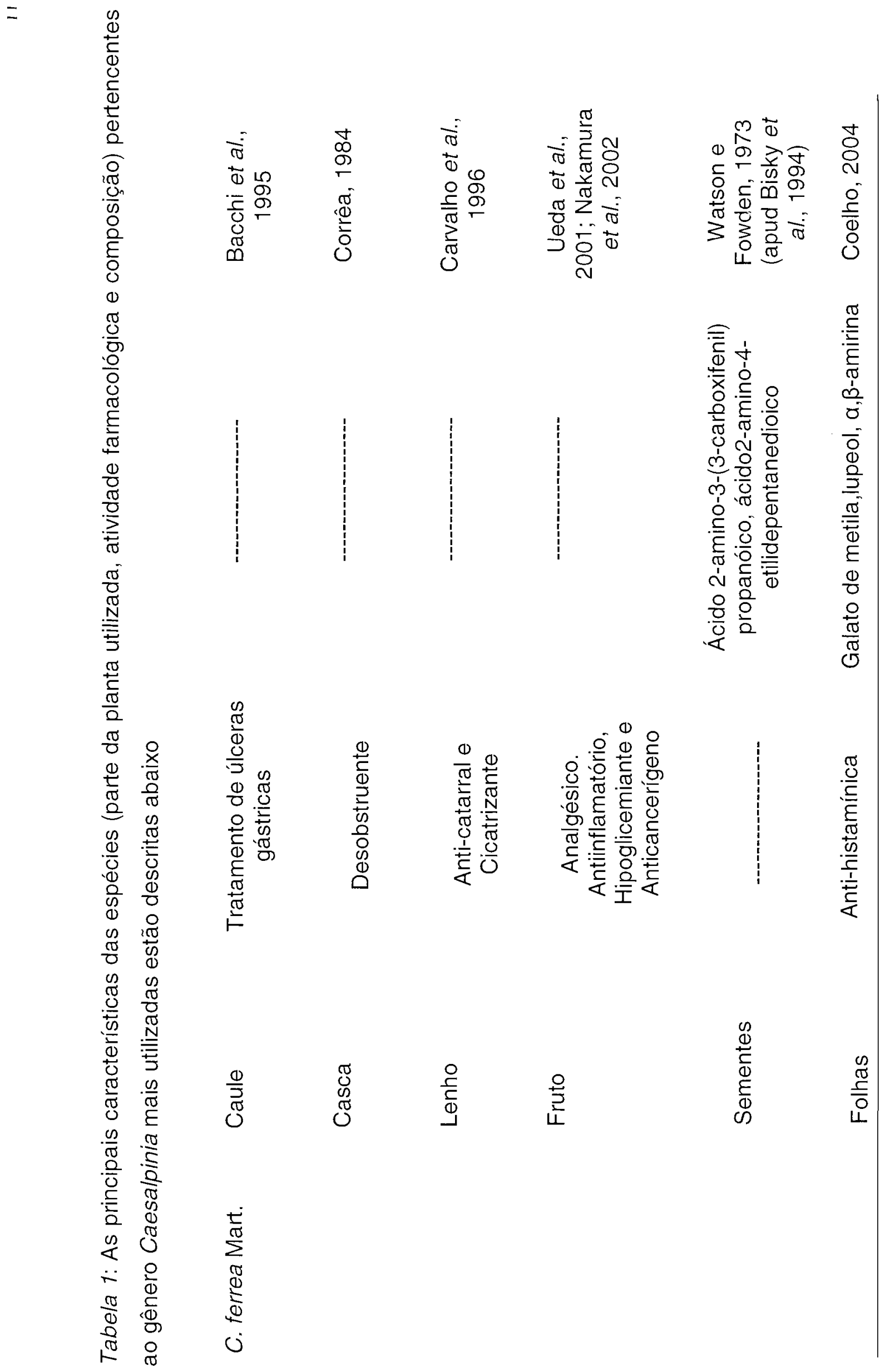




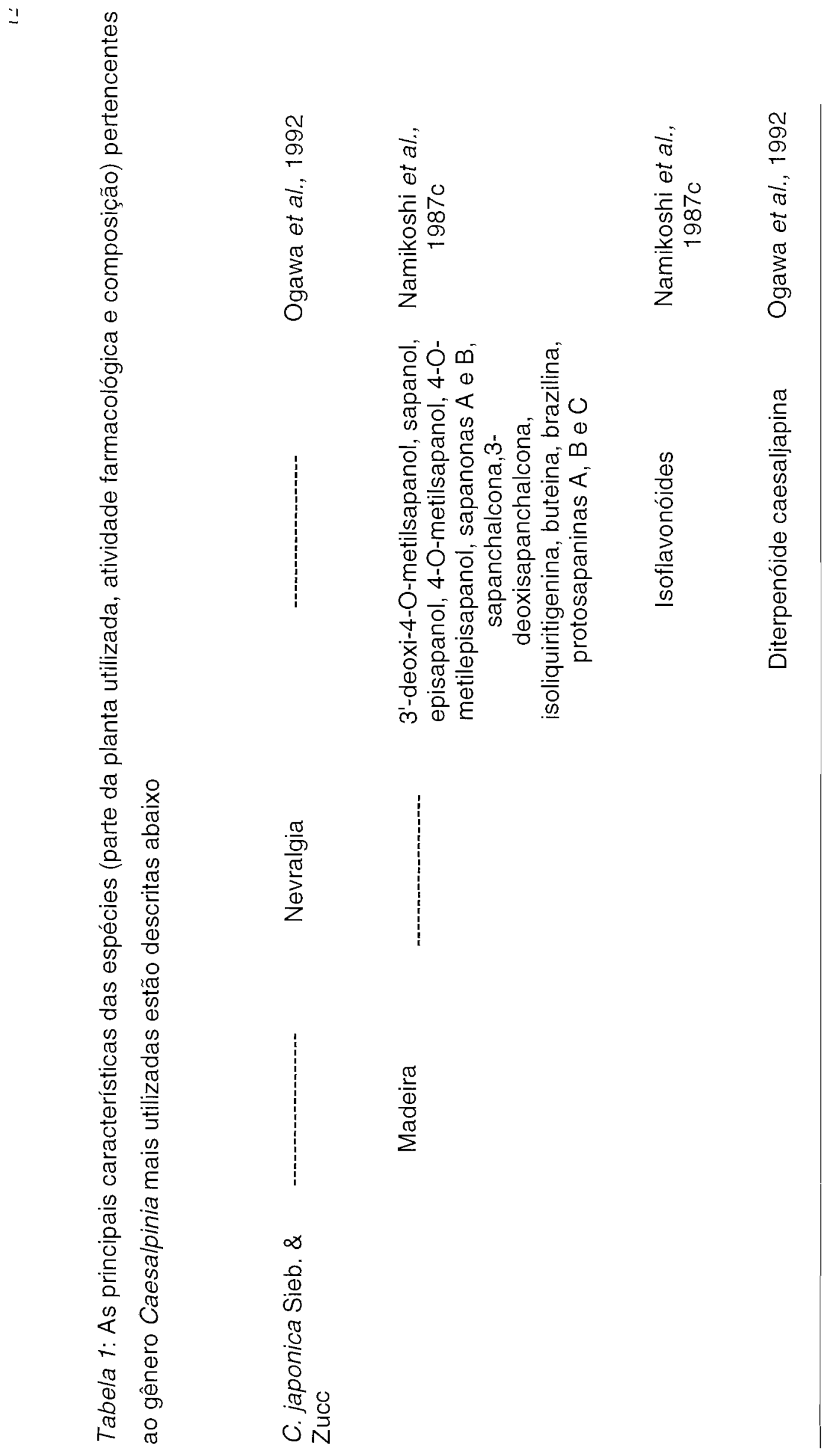




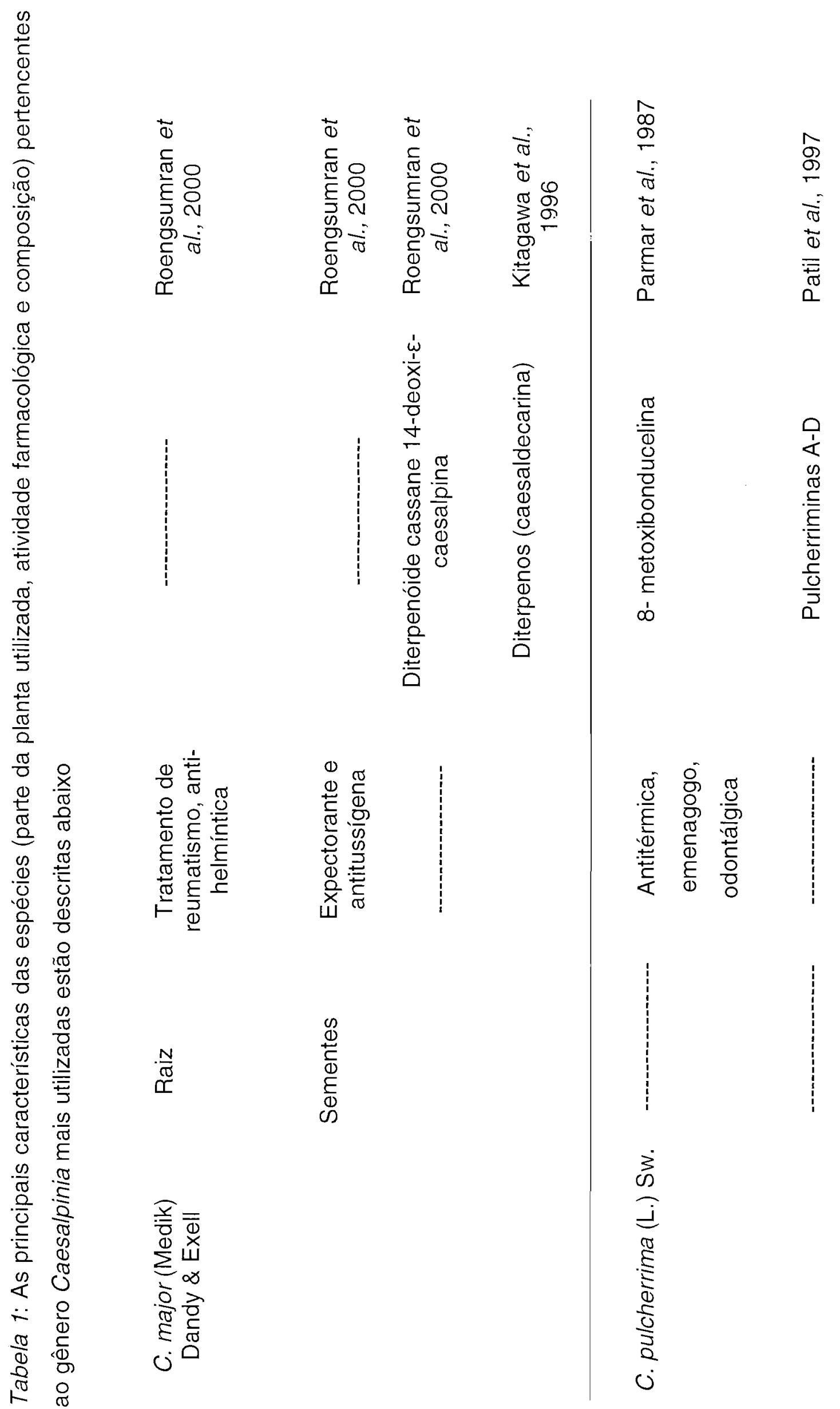




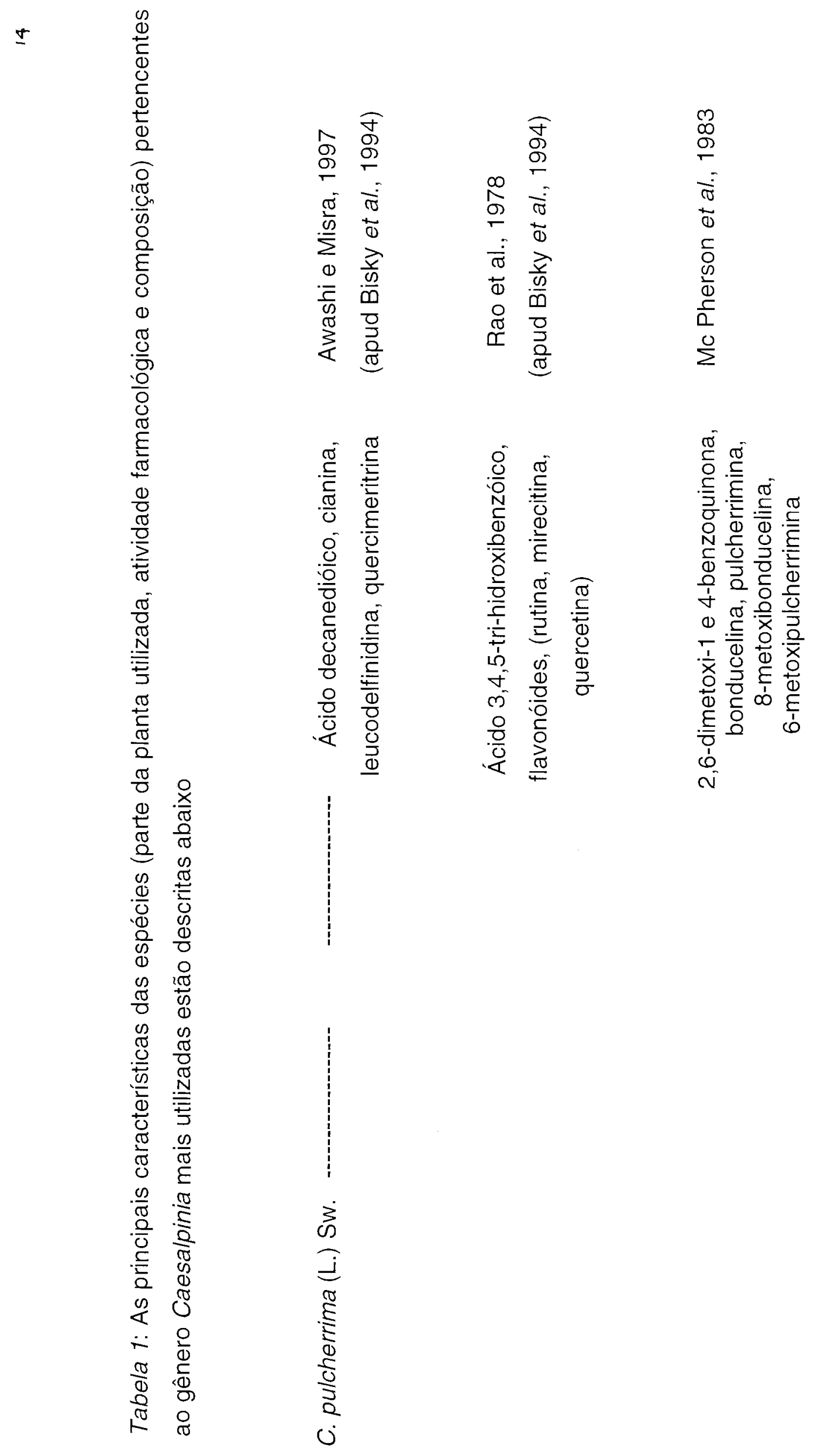



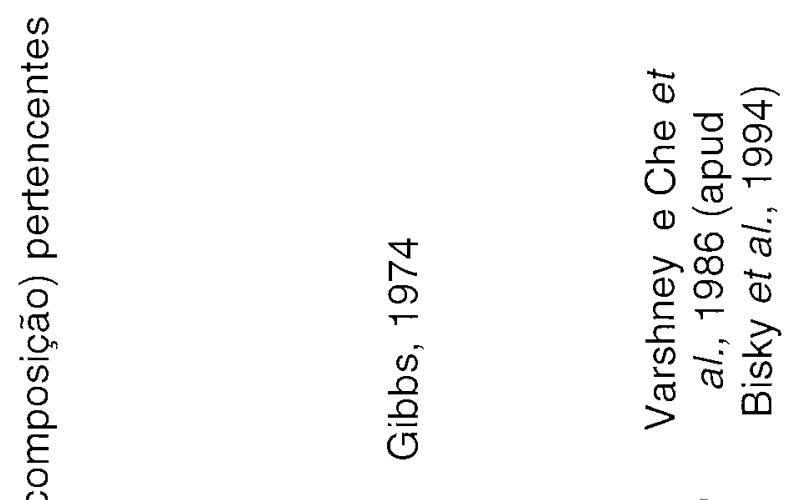

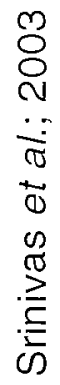

00
0
$\frac{0}{2}$
$\frac{0}{8}$
$\frac{0}{0}$
$\frac{\pi}{0}$

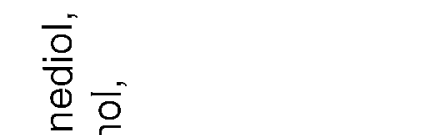

告

()

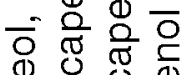

을 음 죽 응

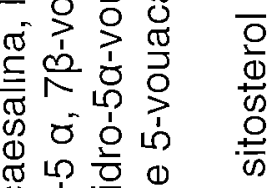

$0 \cdot \frac{1}{x} \frac{0}{0} \infty$

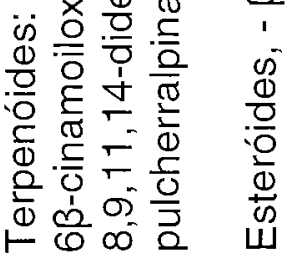

ì

$\frac{0}{0}$

$\frac{\pi}{0}$
$\mathbb{N}$
$\stackrel{N}{=}$
$\frac{\pi}{J}$
$\stackrel{0}{ \pm}$
$\frac{\pi}{0}$

c

$\frac{0}{0}$

$\frac{0}{0}$
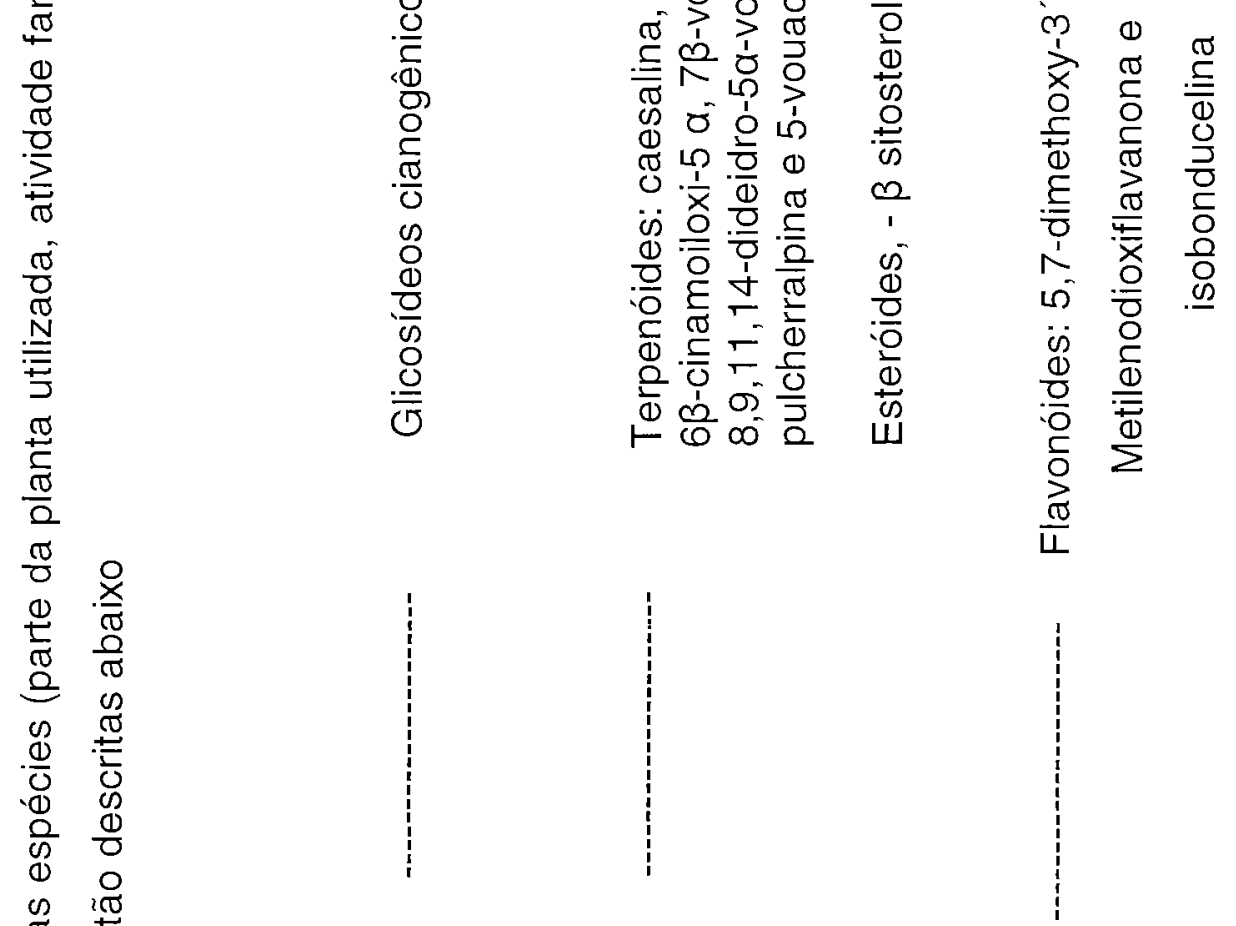

茂

0

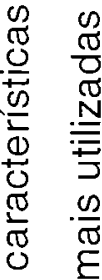

$\frac{\Phi}{\bar{D}} \cdot \frac{N}{\widetilde{N}}$

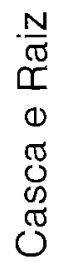

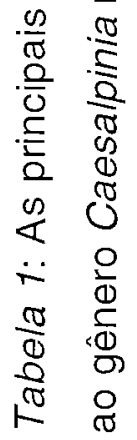

is

趸

1





0
0
0
0
0
0
0
0
$\frac{1}{10}$
0

i

$\frac{\sqrt{2}}{\frac{0}{0}}$

ن 

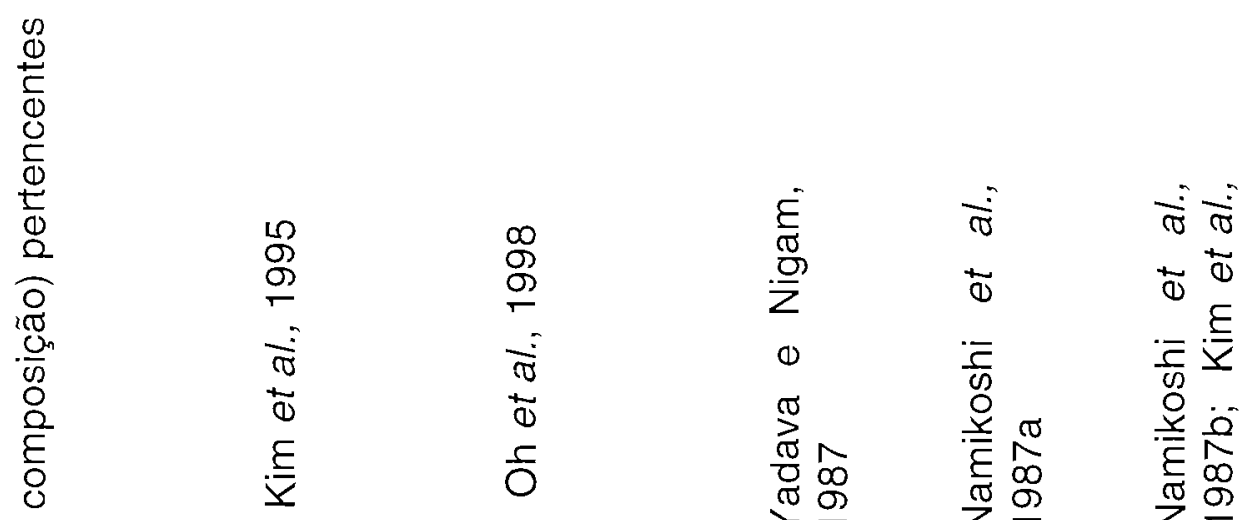

$\frac{1}{2}$

(1)

$\frac{\bar{c}}{\overline{0}}$

范

공

ᄃ

テ

(5

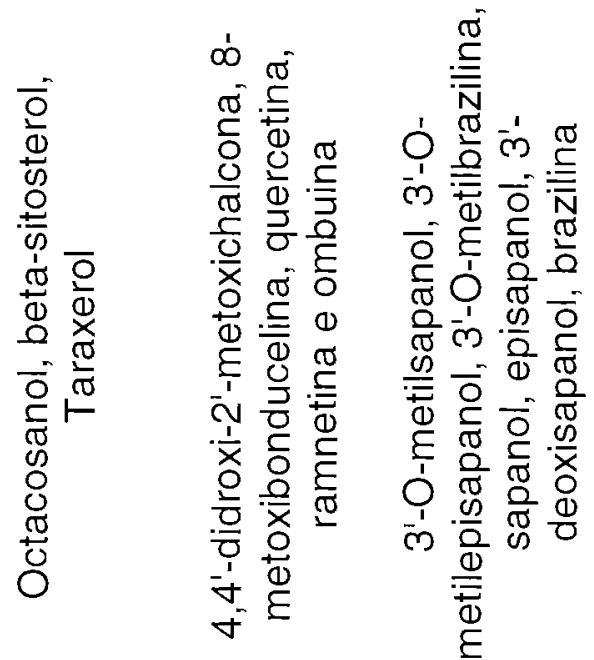

$\stackrel{\frac{\pi}{5}}{\frac{\pi}{2}}$

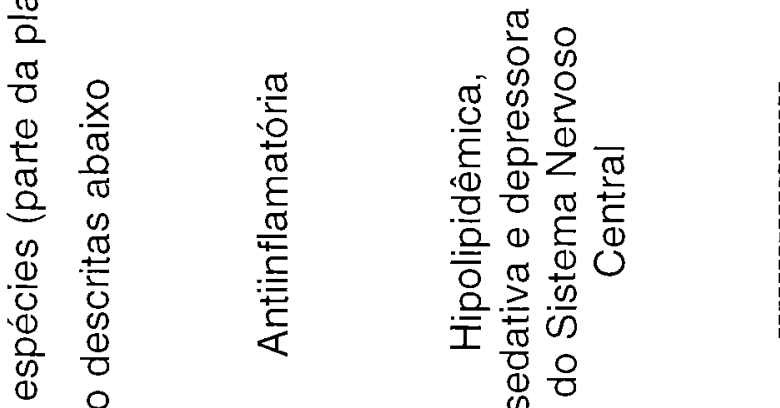

$\frac{\text { 은 }}{\frac{1}{d}}$

(1)

ரु

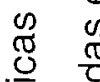

苟

亭

$\frac{\pi}{\pi}$

ठै

$\frac{\omega}{\pi} \cdot \frac{\pi}{\Sigma}$

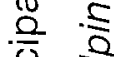

$\frac{\sqrt{2}}{\frac{1}{2}}$

क

$\therefore \quad \frac{0}{0} \quad \frac{2}{5}$

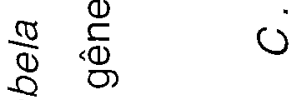

요 


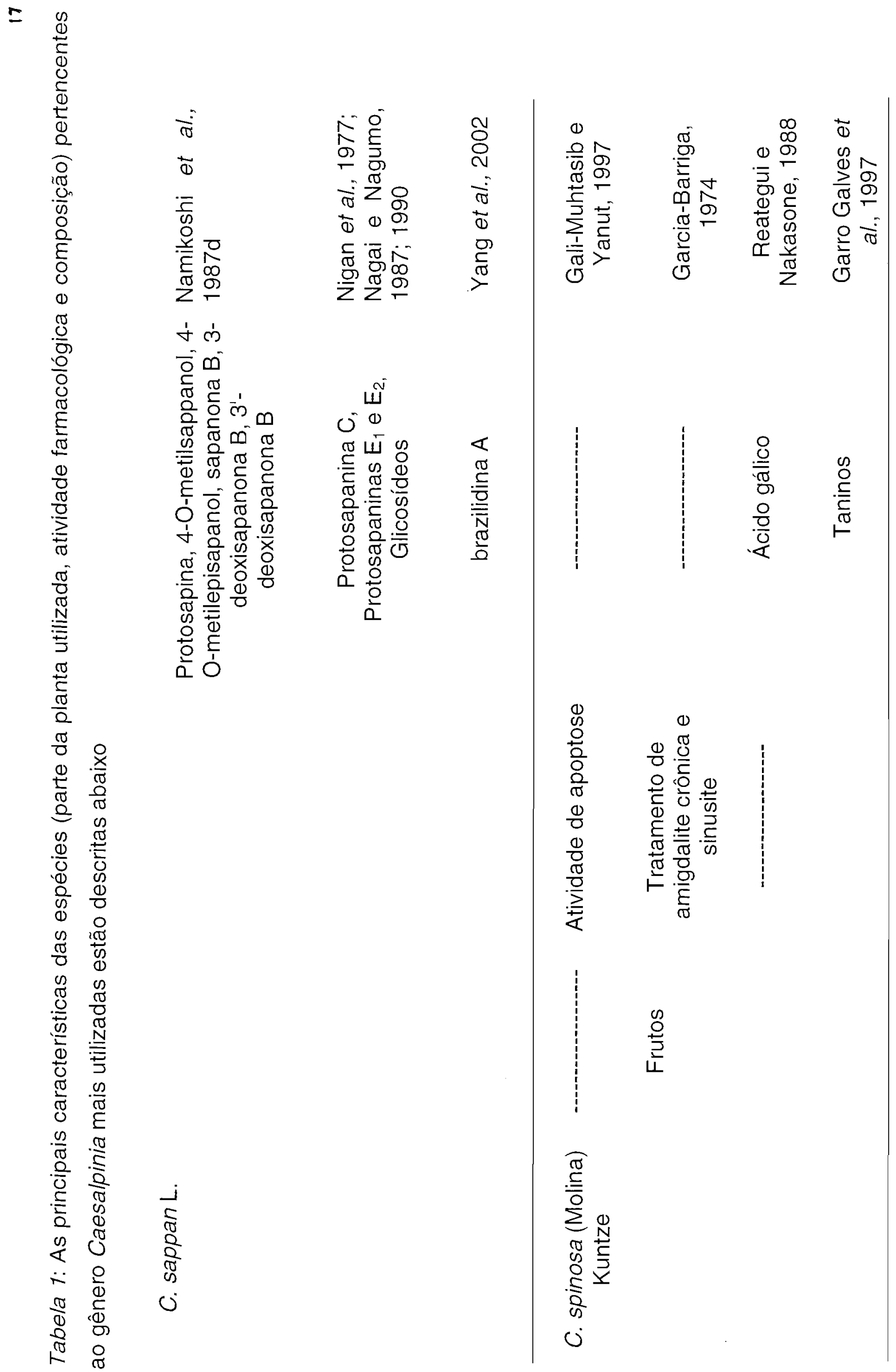




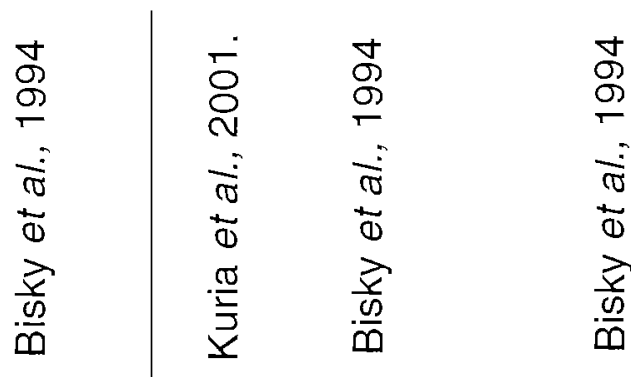




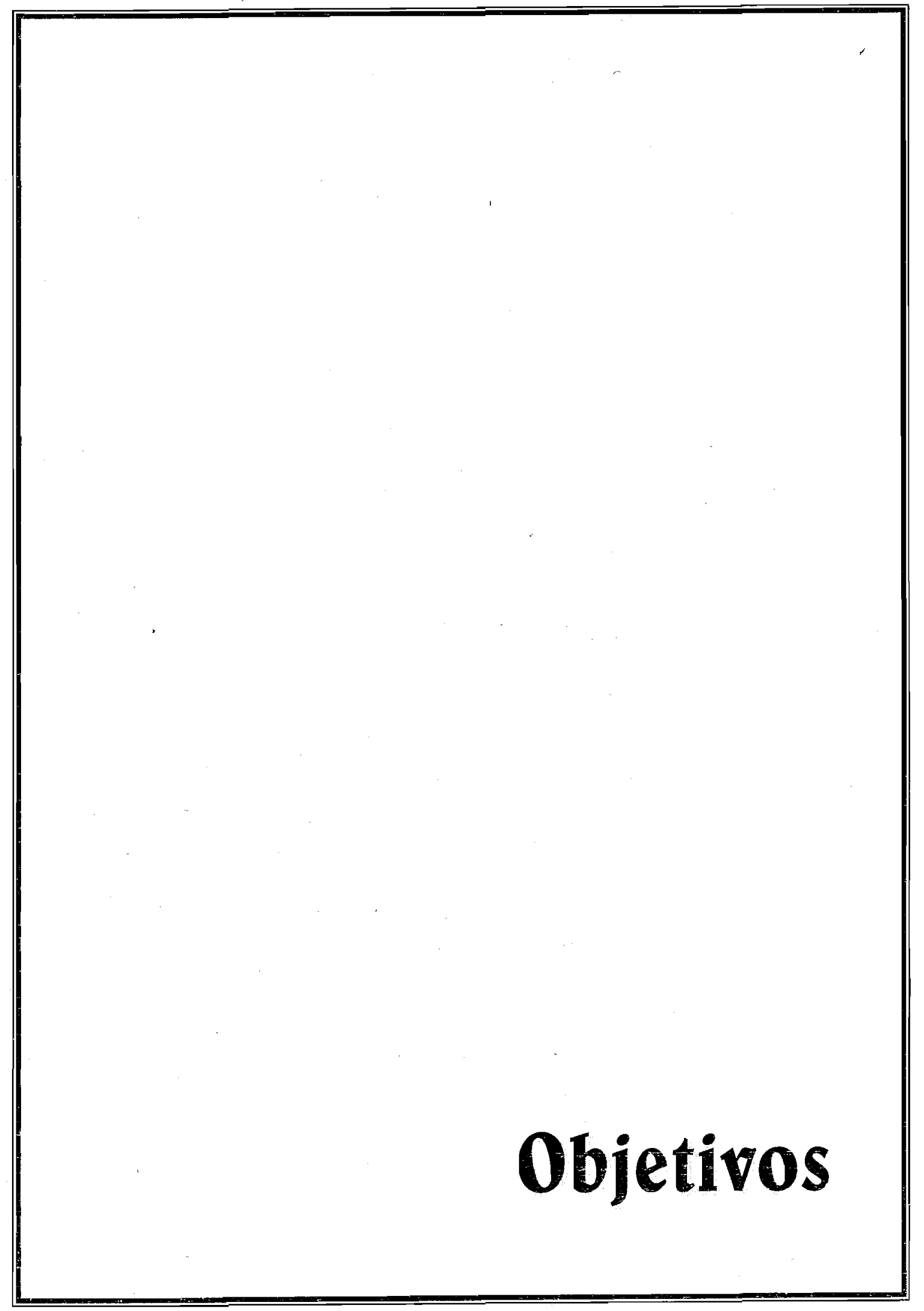




\section{Objetivos}

Os objetivos do presente trabalho são a caracterização farmacobotânica, o estudo químico e farmacológico da espécie C. ferrea, direcionando, às ações antiúlcera e cicatrizante, e toxicidade da espécie. Pretende-se:

- realizar a descrição farmacobotânica para fornecer subsídios que auxiliem na identificação da droga vegetal;

- realizar o perfil cromatográfico dos extratos e frações das drogas vegetais, constituídas de folha ou caule;

- avaliar as ações antiúlcera, em alguns modelos animais, cicatrizante e antioxidante; $\mathrm{DL}_{50}$, toxicidade aguda e subcrônica do extrato bruto liofilizado de folhas e de caule;

- caracterizar os grupos de princípios ativos presentes na espécie estudada. 


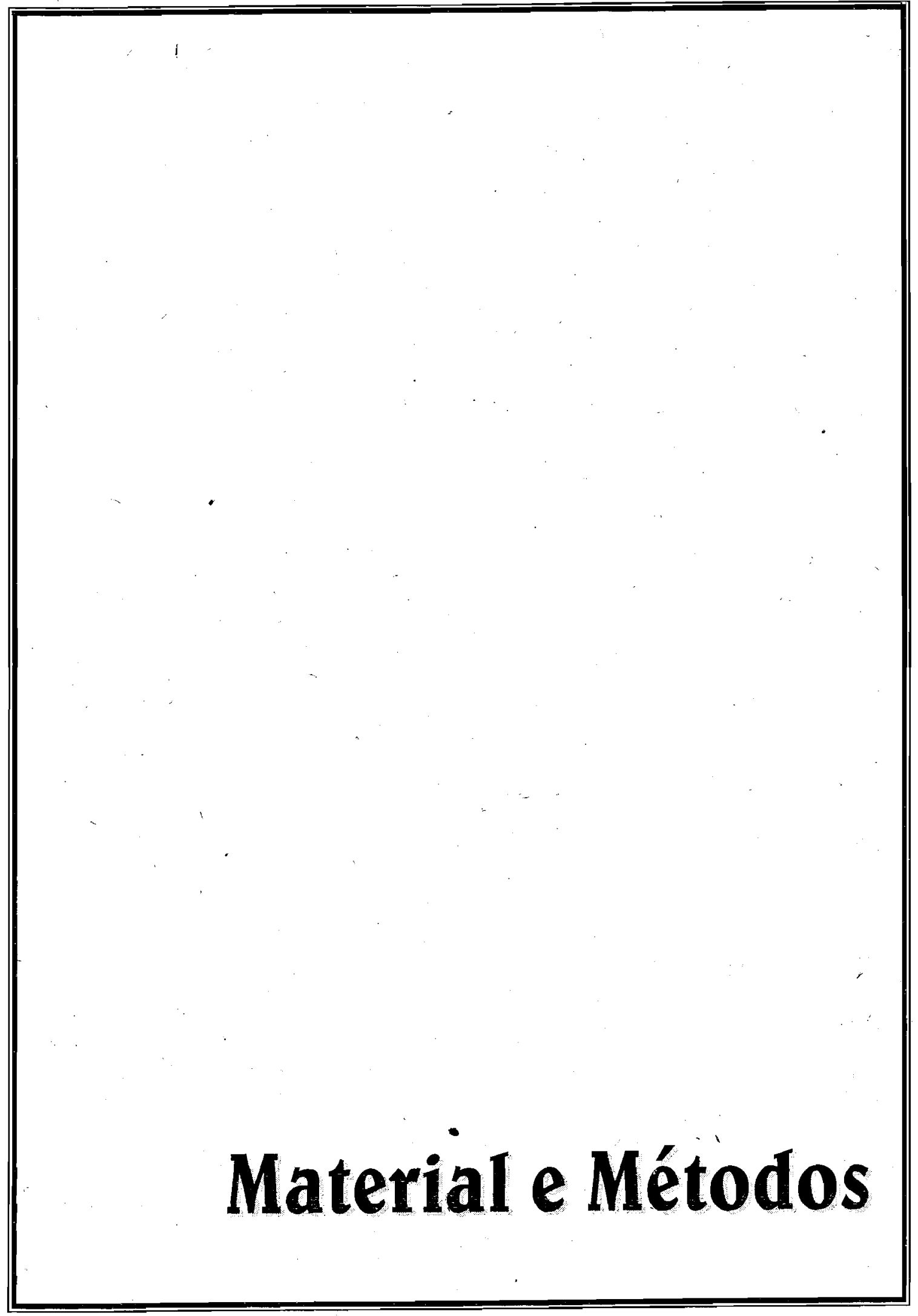




\section{Material e Métodos}

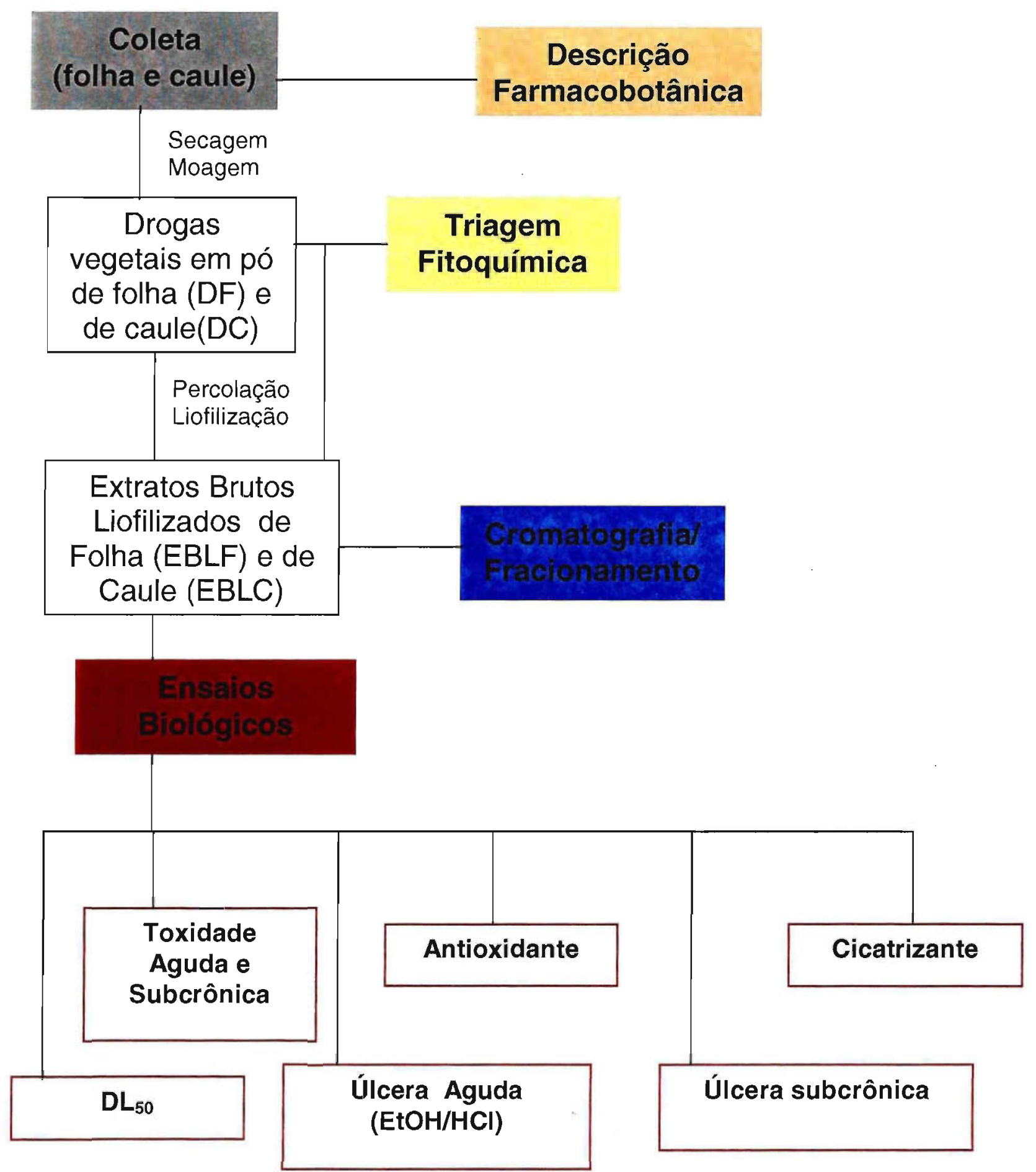

Figura 1: Protocolo geral das atividades realizadas neste trabalho. 


\subsection{Material Vegetal}

Para a preparação do extrato foram utilizados separadamente caules e folhas de um espécime de Caesalpinia ferrea Mart., coletados na cidade universitária "Armando Sales de Oliveira", São Paulo, S.P. A espécie foi identificada por Fabíola Bovo Mendonça (mestre em Botânica do Instituto de Biociências, USP, SP), e a exsicata (FG01) depositada no Herbário SPF do Departamento de Botânica do Instituto de Biociências da Universidade de São Paulo.

\subsection{Coleta}

A coleta foi realizada em março de 2002. Os materiais vegetais (folha e caule) foram coletados por Fabiana Gaspar Gonzalez e Elfriede Marianne Bacchi.

\subsection{Preparo dos Extratos}

\subsubsection{Elaboração dos extratos brutos e frações}

Os órgãos vegetais a serem estudados foram secos em estufa com circulação de ar a $40{ }^{\circ} \mathrm{C}$ e moídos em moinho de martelo e facas, passando por tamis de tamanho apropriado $(1 \mathrm{~mm})$. Os extratos brutos liofilizados foram elaborados através de percolação, segundo Farm.Bras.Il (1988), sendo o etanol retirado em rotaevaporador (à pressão reduzida e a temperatura inferior a $50{ }^{\circ} \mathrm{C}$ ), e a água residual, por liofilização.

Para o fracionamento, foram pesados $80 \mathrm{~g}$ de cada um dos extratos brutos liofilizados e adicionados $800 \mathrm{~mL}$ de clorofórmio. A mistura foi mantida em agitador magnético por 30 minutos. Após agitação, a mistura foi filtrada. $\mathrm{O}$ filtrado (fração clorofórmica) foi concentrado, utilizando-se o banho-maria. Ao resíduo do papel de filtro foram adicionados $800 \mathrm{~mL}$ de acetato de etila; o 
conjunto foi mantido em agitador magnético por mais 30 minutos, repetindo-se exatamente o procedimento anterior até a obtenção do extrato concentrado. Foram realizadas, ainda, extrações com etanol e etanol a 50\% em água, sendo este último concentrado, e a água residual retirada por liofilização.

\subsubsection{Elaboração dos extratos brutos enriquecidos em flavonóides}

A partir de $30 \mathrm{~g}$ de cada um dos Extratos Brutos Liofilizados de Caule (EBLC) e Folha (EBLF) ressuspendidos em $420 \mathrm{~mL}$ de acetato de etila e $240 \mathrm{~mL}$ de água, foram obtidos, por partição em funil de separação, os extratos acetato de etila (Wagner et al., 1984). Estes extratos foram concentrados com auxílio de evaporador rotativo, para eliminação completa do solvente. Os extratos secos foram solubilizados em Tween 80 a $10 \%$ e administrados na dose de $400 \mathrm{mg} / \mathrm{kg}$, via oral, nos animais de experimentação.

\subsection{Descrição Macroscópica e Microscópica das Drogas Vegetais}

\subsubsection{Caracterização farmacobotânica}

As drogas, constituídas de caule e folha de $C$. ferrea, foram analisadas quanto à sua dimensão, forma, aspectos de sua superfície e cor. Para tanto, os materiais foram observados a olho nu ou com auxílio de lupa de pequeno aumento. As mensurações foram feitas com auxilio de régua.

$\mathrm{Na}$ caracterização anatômica das drogas foram empregados o caule e a folha frescos ou fixados em FAA (Johansen, 1940) e conservados em solução de etanol a 70\% (Berly e Miksche, 1976). Foram realizados cortes a mão livre, nos sentidos transversal e longitudinal (Oliveira e Akisue, 1989) de caule e folha do vegetal, os quais foram clareados com solução aquosa de hipoclorito de sódio a $50 \%$ ( $/ \mathrm{v}$ ) e, posteriormente, corados com azul de Astra (Roeser, 1962) e/ou safranina $0,1 \%$, tendo-se utilizado solução aquosa de glicerina a $50 \%(\mathrm{v} / \mathrm{v})$, como meio de montagem de preparações semipermanentes 
(Oliveira e Akisue, 1989).

Nos testes histoquímicos foram utilizados floroglucina clorídrica e safranina para lignina (Oliveira e Akisue, 1989), solução de Sudam III para materiais lipófilos (lipídios, suberina, cutina), cloreto de zinco iodado para celulose, cloreto férrico para compostos fenólicos (Johansen, 1940), constituintes possivelmente presentes nos tecidos das drogas vegetais (Johansen, 1940; Sass, 1951).

As observações microscópicas foram realizadas com auxílio de um microscópico ótico Olympus biocular. Para as fotomicrografias empregou-se fotomicroscópico Nikon, Optiphot com aumento de 40, 100, 200 e 400 vezes.

\subsubsection{Dissociação de elementos celulares}

O material vegetal (caule) foi fragmentado e imerso em uma solução de ácido acético glacial e água oxigenada (20 volumes) $50 \%(\mathrm{v} / \mathrm{v})$. Submeteu-se o conjunto ao aquecimento a $60^{\circ} \mathrm{C}$, por cerca de 15 horas (Franklin, 1945). Após a dissociação, lavou-se com água e, posteriormente, efetuou-se coloração e montagem de acordo com os procedimentos já descritos anteriormente (preparações semipermanentes).

\subsection{Análises Químicas}

\subsubsection{Triagem Fitoquímica}

A triagem fitoquímica foi realizada com o pó da droga vegetal obtida a partir de caule e folha de $C$. ferrea, bem como com seus extratos brutos liofilizados. Os métodos empregados foram preconizados por Farnsworth (1966) e Matos (1988). Os seguintes ensaios foram realizados:

a) ALCALÓIDES: A 2,0 g de amostra foram adicionados $10 \mathrm{~mL}$ de água destilada e ácido clorídrico $0,2 \mathrm{~N}$, até $\mathrm{pH}$ ácido. O conjunto foi aquecido até a fervura por 2 minutos. $O$ filtrado foi transferido para um funil de separação 
e, em seguida, foi adicionado hidróxido de amônio a 10\%, até $\mathrm{pH}$ alcalino. A solução foi extraída com 2 porções de $10 \mathrm{~mL}$ de éter etílico, em funil de separação. A fração etérea foi concentrada em rotavapor e ao residuo foram acrescentados $2 \mathrm{~mL}$ de $\mathrm{HCl} 0,2 \mathrm{~N}$, seguindo-se os testes de precipitação com os reativos de Bertrand (ácido silicotúngstico a 5\%), Bouchardat (solução aquosa de iodo em iodeto de potássio) Dragendorff (solução aquosa de ácido nítrico 6\%, subnitrato de bismuto $8 \%$ e iodeto de potássio a $23 \%$ ) e Mayer (solução de cloreto férrico a 1,3\% e iodeto de potássio a $5 \%$ ).

O aparecimento de precipitado, após a adição dos reagentes, foi considerado como indicativo da presença de alcalóides nas drogas vegetais ou nos extratos brutos liofilizados.

b) ANTRADERIVADOS: A 2,0 g de amostra foram adicionados $10 \mathrm{~mL}$ de ácido sulfúrico $2 \mathrm{~N}$ e o conjunto foi aquecido até a fervura por 2 minutos. $\mathrm{O}$ filtrado foi transferido para funil de separação e extraído com $10 \mathrm{~mL}$ de éter etílico. A fase etérea foi transferida para um tubo de ensaio e foram adicionados $2 \mathrm{~mL}$ de solução aquosa de hidróxido de sódio $2 \mathrm{~N}$.

$\mathrm{O}$ aparecimento de coloração vermelha intensa na fase aquosa após a agitação foi considerado como indicativo da presença de antraquinonas nas drogas vegetais ou nos extratos (Reação de Bornträger).

b) CUMARINAS: 2,0 $\mathrm{g}$ de amostra foram lavados com éter de petróleo a frio. Depois de lavado, o pó foi colocado em um béquer e extraído com $10 \mathrm{~mL}$ de solução de hidróxido de sódio $0,5 \mathrm{~N}$ a quente. A mistura foi filtrada e o extrato acidificado com ácido clorídrico $1 \mathrm{~N}$. Após acidificação, a extração foi realizada com éter etílico. $O$ extrato etéreo foi colocado em cápsula de porcelana e concentrado. A seguir, foi tratado com uma gota de solução saturada de hidroxilamina em álcool e uma gota de solução alcoólica de hidróxido de potássio a 0,5N. A mistura foi aquecida até início da fervura e após resfriamento, adicionada uma gota de ácido clorídrico $0,5 \mathrm{~N}$ e uma gota de solução de cloreto férrico $1 \%$. 
d) GLICÓSIDOS CARDIOTÔNICOS: A 2,0 g de amostra foram adicionados $20 \mathrm{~mL}$ de etanol $50 \%$ e o conjunto foi aquecido até fervura por 1 minuto e filtrado a seguir. O processo foi repetido por 2 vezes. Aos filtrados reunidos foram adicionados $10 \mathrm{~mL}$ de solução saturada de acetato básico de chumbo. Após a agitação, a mistura permaneceu em repouso até sedimentação do precipitado formado. O sobrenadante foi transferido para um funil de separação e extraído com 2 porções de $15 \mathrm{~mL}$ de clorofórmio. A fração clorofórmica foi filtrada através de sulfato de sódio anidro e posteriormente concentrada. Esta fração foi submetida às reações de Liebermann-Burchard. Kedde, Baljet e Keller-Killiani.

O aparecimento de coloração vermelho-acastanhada na região de contato dos dois líquidos foi considerado reação positiva para a presença do núcleo esteroidal (Reação de Liebermann-Burchard), de cor violácea (Reação de Kedde), alaranjada (Reação de Baljet), para o anel lactônico pentagonal e vermelho-acastanhada (Reação de Keller-Killiani), para 2desoxiaçúcares.

e) FLAVONÓIDES: A 2,0 g de amostra foram adicionados $15 \mathrm{~mL}$ de etanol $70 \%$ e o conjunto foi aquecido até fervura por 2 minutos e filtrado a seguir. Esta solução foi utilizada nas reações para identificação de flavonóides:

\section{* Reação de Cloreto de Alumínio}

As soluções foram gotejadas em papel de filtro em duas áreas distintas. Em uma das áreas foi adicionada uma gota de solução de cloreto de alumínio em etanol a $5 \%(\mathrm{p} / \mathrm{v})$. O papel de filtro foi observado sob luz ultravioleta no comprimento de onda de $365 \mathrm{~nm}$. O desenvolvimento ou intensificação de fluorescência na zona de contato com a solução de cloreto de alumínio foi considerado reação positiva para flavonóides; 
* Reação de Shinoda

À solução previamente obtida foram adicionados 2 a 3 fragmentos de magnésio metálico e $1 \mathrm{~mL}$ de ácido clorídrico concentrado. $\mathrm{O}$ desenvolvimento de coloração rósea a vermelha foi considerado como indicativo da presença de flavonóides;

\section{* Reação com Hidróxidos Alcalinos}

A $2 \mathrm{~mL}$ da solução previamente obtida foi adicionado $0,5 \mathrm{~mL}$ de solução de hidróxido de sódio $1 \mathrm{~N}$. A intensificação da coloração amarela foi considerada reação positiva para flavonóides;

f) TANINOS: A 1,0 g de amostra foram adicionados $50 \mathrm{~mL}$ de água destilada, o conjunto foi aquecido, mantido em fervura por 5 minutos e filtrado.

Alíquotas das soluções obtidas a partir das drogas vegetais e dos extratos brutos liofilizados foram separadas para a realização dos ensaios de identificação descritos a seguir.

\section{* Reação com Sais de Ferro}

A $2 \mathrm{~mL}$ de cada solução aquosa obtida foram adicionados $5 \mathrm{~mL}$ de água destilada e 2 a 3 gotas de solução de cloreto férrico $2 \%$. O desenvolvimento de precipitado ou a mudança de coloração foram considerados reação positiva para compostos fenólicos. 
- Reação com Acetato e Chumbo

A $2 \mathrm{~mL}$ de cada solução aquosa obtida foram adicionadas 3 gotas de solução aquosa de acetato de chumbo 10\%. O desenvolvimento de precipitado foi considerado reação positiva para compostos fenólicos.

\section{- Reação com Acetato de Cobre}

A uma alíquota de $2 \mathrm{~mL}$ de cada solução aquosa obtida foram adicionadas 2 a 3 gotas de solução aquosa de acetato de cobre $3 \%$. O desenvolvimento de precipitado foi considerado reação positiva para compostos fenólicos.

\section{* Reação com Alcalóides}

A uma alíquota de $2 \mathrm{~mL}$ de cada solução aquosa obtida foram adicionados 1 gota de ácido clorídrico a $10 \%$ e 5 gotas de solução aquosa de sulfato de quinina a $0,1 \%$. $O$ desenvolvimento de precipitado foi considerado reação positiva.

\section{* Reação com Gelatina}

A $2 \mathrm{~mL}$ de cada solução aquosa obtida foi adicionada 1 gota de ácido clorídrico $10 \%$ e $0,5 \mathrm{~mL}$ de gelatina 2,5\%, gota a gota. O desenvolvimento de precipitado foi considerado reação positiva.

g) SAPONINAS: A $0,5 \mathrm{~g}$ de amostra foram adicionados $20 \mathrm{~mL}$ de água destilada e o conjunto foi aquecido até a fervura por 2 minutos. Após resfriamento, a mistura foi filtrada para balão volumétrico de $50 \mathrm{~mL}$, 
mantendo-se o sólido no béquer. O procedimento foi repetido com porções de $10 \mathrm{~mL}$ de água destilada até que o volume do balão fosse completado.

Os extratos aquosos a $1 \%$ foram utilizados para a avaliação da presença de saponinas nas drogas vegetais e nos extratos (EBL).

\section{* Espuma}

Em tubo de ensaio provido de tampa foram colocados $5 \mathrm{~mL}$ da solução aquosa obtida das drogas vegetais. $O$ tubo foi agitado vigorosamente por 15 segundos e deixado em repouso por 15 minutos.

O mesmo procedimento descrito acima foi realizado empregando-se as soluções aquosas obtidas a partir dos extratos brutos liofilizados.

A verificação de uma camada de espuma persistente de ao menos $1 \mathrm{~cm}$ foi considerada indicativa da presença de glicósidos saponínicos.

\section{* Hemólise}

Cinco mililitros da solução aquosa obtida das drogas vegetais foram previamente isotonizados com cloreto de sódio e colocados em um tubo de ensaio com $2 \mathrm{~mL}$ de uma suspensão de sangue bovino desfibrinado $2 \%$ em solução fisiológica.

O tubo foi homogeneizado e após 1 hora de repouso foi avaliada a ocorrência de hemólise.

h) ÓLEO ESSENCIAL: 2,0 g de amostra foram colocados em anel metálico entre duas lâminas microscópicas e submetidos ao aquecimento, na presença de água. As gotículas do hidrodestilado, depositadas na lâmina superior, foram analisadas ao microscópio óptico com reagente Sudam III. 
4.5.2 Perfil Cromatográfico do extrato bruto e das frações de caule e folha de Caesalpinia ferrea Mart.

Foi realizada análise cromatográfica em camada delgada para delineamento do perfil cromatográfico dos extratos brutos e frações em clorofórmio, acetato de etila, etanol e etanol 50\% em água, obtidas a partir do EBLC e EBLF de C. ferrea, através de comparação com padrões. Os seguintes sistemas cromatográficos foram utilizados:

CAULE:

\section{* Sistema A:}

- Tamanho da placas: 15X20 cm;

- Fase estacionária: Sílica gel $\mathrm{GF}_{254 ;}$

- Espessura da camada: 300ụm;

- Ativação: $110^{\circ} \mathrm{C}$, por 1 hora;

- Saturação da cuba: Total;

- Percurso: distância-12 cm; sentido: ascendente;

- Fase móvel: Hexano: Acetato de Etila (9:1);

- Quantidade de amostra aplicada: extrato bruto, frações etanol e etanol 50\% em água (2ụl) e frações clorofórmio, e acetato de etila $(1,5 u ̣ l)$;

- Padrões: ácido cafeico (1\%) em metanol e ácido clorogênico (0.5\%) em metanol;

- Revelador: difenilboriloxietilamina 1\% em metanol (NP) + polietilenoglicol 5\% em metanol (PEG);

Visualização: UV 365nm

Nos sistemas a seguir, todos os parâmetros são idênticos ao Sistema 1, mudando a fase móvel e os padrões. 


\section{$\leftarrow$ Sistema B:}

- Fase móvel: Clorofórmio: Acetato de Etila: Acetona (75:8,5:16,5).

- Padrões: ácido clorogênico $(0,5 \%)$ em metanol e naringenina $(0,5 \%)$ em metanol

\section{- Sistema C:}

- Fase móvel: Clorofórmio: Acetato de Etila: Etanol (98:2:3)

- Padrões: ácido cafeico (1\%) em metanol e ácido clorogênico (0,5\%) em metanol

\section{FOLHA:}

\section{$\leftarrow$ Sistema A:}

- Fase móvel: I- Acetato de Etila: Ácido Fórmico: Butanona: Água (75:10:5:10), seguido de II- Acetato de Etila: Ácido Acético (95:5)

- Padrões: ácido gálico (1\%) em metanol

\subsection{Quantificação de Taninos das Drogas Vegetais e dos Extratos Brutos Liofilizados (EBL)}

O doseamento de taninos nas drogas vegetais e nos extratos brutos liofilizados foi realizado conforme preconizado pela European Pharmacopoeia (2001). O resultado foi expresso em porcentagem de taninos. O método baseia-se na reação colorimétrica dos polifenóis com o ácido fosfomolibdotúngstico, utilizando-se como referência o pirogalol (Sigma). 
* Quantificação

A $0,75 \mathrm{~g}$ de droga vegetal foram adicionados $150 \mathrm{~mL}$ de água destilada. O conjunto foi aquecido em banho-maria por 30 minutos, resfriado e transferido quantitativamente para balão volumétrico de $250 \mathrm{~mL}$. Após a decantação dos sólidos, o conjunto foi filtrado por papel de filtro (F1). Foram descartados os 50 $\mathrm{mL}$ iniciais de $\mathrm{F} 1$.

O mesmo procedimento descrito acima foi realizado utilizando-se $0,300 \mathrm{~g}$ de Extrato Bruto Liofilizado de Caules (EBLC-F2c) e Folhas (EBLF-F2f).

\section{- Polifenóis Totais}

Cinco mililitros do filtrado obtido a partir da droga vegetal (F1) foram diluídos em água destilada em balão volumétrico de $25 \mathrm{~mL}$. A $2 \mathrm{~mL}$ desta solução foram adicionados $1 \mathrm{~mL}$ de reagente fosfomolibdotúngstico e $10 \mathrm{~mL}$ de água destilada em balão volumétrico de $25 \mathrm{~mL}$ e o volume foi completado com solução de carbonato de sódio (29\%). Após 30 minutos foi feita a leitura da absorbância a 760nm $\left(A_{1}\right)$, usando água como branco.

O mesmo procedimento foi realizado utilizando-se o filtrado obtido a partir dos extratos brutos liofilizados (F2c e F2f).

\section{* Polifenóis não Adsorvidos pelo Pó de Pele}

A $10 \mathrm{~mL}$ do filtrado obtido a partir da droga vegetal (F1) foram adicionados $0,10 \mathrm{~g}$ de pó de pele cromada Merck. O conjunto foi levado à agitação em agitador magnético durante 1 hora sendo, em seguida, filtrado através de papel de filtro. Cinco mililitros deste filtrado foram diluídos com água destilada em balão volumétrico de $25 \mathrm{~mL}$. A $2 \mathrm{~mL}$ desta solução foram adicionados $1 \mathrm{~mL}$ de reagente fosfomolibdotúngstico e $10 \mathrm{~mL}$ de água destilada em balão volumétrico de $25 \mathrm{~mL}$ e o volume foi completado com solução de carbonato de sódio (29\%). Após 30 minutos foi feita a leitura da absorbância a $760 \mathrm{~nm}\left(\mathrm{~A}_{2}\right)$, usando água como branco. 
O mesmo procedimento foi realizado utilizando-se o filtrado obtido a partir dos extratos brutos liofilizados (F2).

\section{+ Padrão}

Imediatamente antes do uso, $50 \mathrm{mg}$ de pirogalol (Merck) foram diluídos em água em um balão volumétrico de $100 \mathrm{~mL}$. A $2 \mathrm{~mL}$ desta solução foram adicionados $1 \mathrm{~mL}$ do reagente fosfomolibdotúngstico e $10 \mathrm{~mL}$ de água em balão volumétrico de $25 \mathrm{~mL}$ e o volume foi completado com a solução de carbonato de sódio. Após 30 minutos foi feita a leitura da absorbância a 760nm $\left(A_{3}\right)$, usando água como branco.

O teor de taninos foi calculado em porcentagem através da equação:

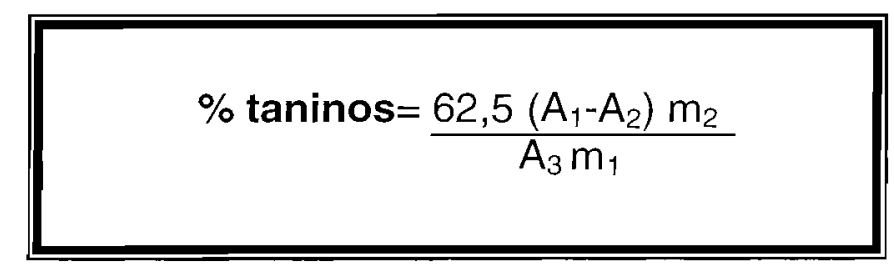

Onde:

$A_{1}=$ Absorbância dos polifenóis totais a $760 \mathrm{~nm}$;

$A_{2}=$ Absorbância dos polifenóis não adsorvidos pelo pó de pele a $760 \mathrm{~nm}$;

$A_{3}=$ Absorbância do padrão de pirogalol a $760 \mathrm{~nm}$;

$m_{1}=$ massa da amostra analisada (drogas vegetais ou extratos brutos liofilizados) em gramas;

$\mathrm{m}_{2}=$ massa do pirogalol em gramas. 


\subsection{Quantificação de Flavonóides das Drogas Vegetais e dos Extratos Brutos Liofilizados (EBL)}

O doseamento de flavonóides nas drogas vegetais e nos extratos brutos liofilizados foi realizado conforme preconizado pela Farmacopéia Brasileira (2003). A porcentagem de flavonóides foi calculada em relação à quercetina.

- Determinação de Água

Dois gramas das drogas vegetais e dos extratos brutos liofilizados foram levados à estufa a 100-105 ${ }^{\circ} \mathrm{C}$, separadamente, por 5 horas. Após o resfriamento em dessecador, as drogas vegetais e os extratos brutos liofilizados foram pesados até que a massa entre as pesagens não diferisse em mais de $5 \mathrm{mg}$ em 3 pesagens consecutivas. A determinação de água foi calculada em porcentagem em relação à massa da amostra inicial através da fórmula:

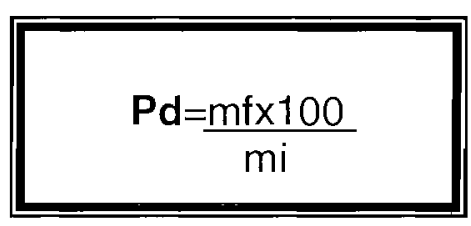

Onde:

$\mathrm{Pd}=$ determinação de água em porcentagem;

$\mathrm{mi}=$ massa inicial da amostra em gramas;

$\mathrm{mf}=$ massa final da amostra, após a secagem, em gramas.

\section{* Quantificação}

Uma massa de $0,4 \mathrm{~g}$ da droga vegetal constituída de folhas e $4 \mathrm{~g}$ da droga vegetal constituída de caules foram aquecidas à fervura sob refluxo durante 30 minutos com $20 \mathrm{~mL}$ de acetona, $1 \mathrm{~mL}$ da solução de metenamina $(0,5 \%)$ e $2 \mathrm{~mL}$ de ácido clorídrico. A mistura foi filtrada por algodão para um 
balão volumétrico de $100 \mathrm{~mL}$. O resíduo das drogas e o algodão foram extraídos mais duas vezes usando-se porções de $20 \mathrm{~mL}$ de acetona com aquecimento à fervura sob refluxo por 10 minutos. Os filtrados de cada uma das drogas vegetais foram reunidos no balão e o volume completado para 100 $\mathrm{mL}$ com acetona.

A $20 \mathrm{~mL}$ das soluções obtidas foram adicionados $20 \mathrm{~mL}$ de água e 15 $\mathrm{mL}$ de acetato de etila, em funil de separação. A fase de acetato de etila foi recolhida e foram realizadas mais 3 extrações empregando-se porções de 10 $\mathrm{mL}$ de acetato de etila. Após a reunião das fases de acetato de etila, foram realizadas 2 lavagens com porções de $50 \mathrm{~mL}$ de água. A fase orgânica foi completada com acetato de etila em balão volumétrico de $50 \mathrm{~mL}$ (Solução Mãe).

A $10 \mathrm{~mL}$ de cada uma das Soluções Mãe foi adicionado 1,0 mL da solução de cloreto de alumínio e o volume foi completado para $25 \mathrm{~mL}$ em balão volumétrico com solução metanólica a $5 \%(v / v)$ de ácido acético. Foi preparada uma solução de comparação (branco) diluindo-se $10 \mathrm{~mL}$ de Solução Mãe a $25 \mathrm{~mL}$ em balão volumétrico com solução metanólica a $5 \%$ (v/v) de ácido acético.

Após 30 minutos foi lida a absorbância da amostra a 425 nm, utilizandose a solução sem a adição do cloreto de alumínio como o branco.

O mesmo procedimento para o doseamento de flavonóides foi realizado partindo-se de 0,4 $\mathrm{g}$ de extratos brutos liofilizados de folha e caule da espécie em estudo.

\section{* Cálculo}

O teor de flavonóides foi calculado em porcentagem como quercetina através da equação:

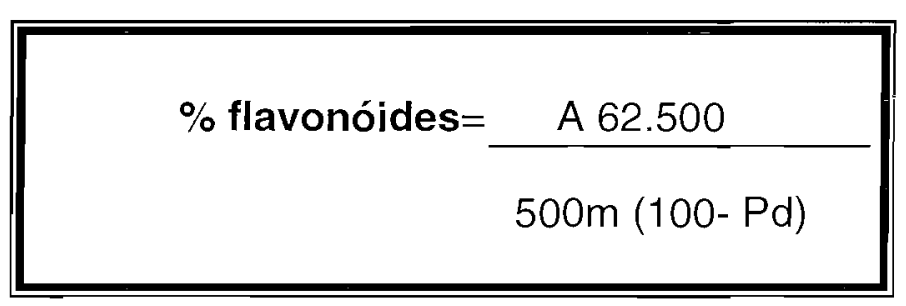


Onde:

$A=$ absorbância da amostra a $425 \mathrm{~nm}$;

$\mathrm{m}=$ massa da amostra em gramas;

$\mathrm{Pd}=$ determinação da porcentagem de água presente na amostra

\subsection{Ensaios Biológicos}

\subsubsection{Avaliação da Toxicidade}

$+\mathrm{DL}_{50}$

Para a realização do ensaio de dose letal 50\% foram utilizados 10 camundongos Swiss por grupo, sendo 5 machos e 5 fêmeas (Brito, 1994).

Estes animais foram agrupados em caixas por sexo e submetidos a jejum por 6 horas e, após este período, receberam, por via oral, água (Grupo Controle) e doses progressivas de extrato bruto de folha de C. ferrea (961.3; 1538; 2461; 3938; $6300 \mathrm{mg} / \mathrm{kg}$ - Grupo Tratado). Além destas 5 doses, as fêmeas receberam mais uma dose de $10.080 \mathrm{mg} / \mathrm{kg}$. Após 30, 60, 90 e 120 minutos, 24 e 48 horas da administração até o $14^{\circ}$ dia de tratamento, observouse o número de animais que vieram a óbito, em cada um dos tempos, dentro de cada uma das doses.

O método para cálculos dos valores de $\mathrm{DL}_{50}$ em bioensaios é o Trimmed Spearman - Karber (Hamilton et al., 1977).

*TOXICIDADE AGUDA

O ensaio para avaliação da toxicidade aguda, dose simples, de extrato bruto de caule e folha foi conduzido segundo o protocolo descrito por Brito 
(1994). Este ensaio pretende avaliar o potencial de toxicidade aguda de extratos vegetais, quando administrado por via oral a camundongos, na dose única de $5000 \mathrm{mg} / \mathrm{kg}$.

Os extratos secos foram diluídos em água. A suspensão foi administrada a grupos machos e fêmeas. Conforme recomendado nos protocolos, o volume administrado não deve exceder $1 \mathrm{~mL}$ por 100 gramas de massa do animal. 0 grupo controle (5 machos e 5 fêmeas) recebeu volume de água destilada, por grama de peso de animal, equivalente ao do extrato, nos grupos tratados.

Os camundongos da linhagem Swiss (25-35g), machos e fêmeas, permaneceram em jejum por cerca de 6 horas antes da administração das doses, porém com água fornecida ad libitum. Após administração do veículo e extratos, todos os grupos foram deixados sem ração e água nas primeiras quatro horas, e observados ao longo deste período e a cada 24 horas, durante 14 dias, verificando-se comportamentos tais como agitação, piloereção, irritabilidade, resposta ao toque, aperto de cauda, contorção, força de agarrar, tremores, convulsão, respiração, número de mortos (adaptado de Brito, 1994, Figura 2). O peso corpóreo individual, o consumo de água e ração, para cada grupo de 5 animais, foram anotados a cada 48 horas.

Decorridos os 14 dias, os animais foram mortos e tiveram seus órgãos retirados (fígado, rins, coração/pulmão), analisados macroscopicamente quanto a possíveis alterações e pesados. 
Figura 2: Teste Hipocrático - Toxicidade de drogas por Análise comportamental (adaptado de Brito, 1994).

Droga.

;Via de administração.

Dose. $\mathrm{mg} / \mathrm{Kg}$; Volume de injeção: ml; Concentração da

Droga. Hora da injeção. hs.; Data...... /....................;

Animal. Sexo: ( ) Masc. ( ) Fem.; Peso. g; Tempo de jejum

\begin{tabular}{|c|c|c|c|c|c|c|}
\hline \multirow[t]{2}{*}{ Sintoma } & \multicolumn{6}{|c|}{ Tempo } \\
\hline & $30^{\prime}$ & $60^{\prime}$ & $2 \mathrm{~h}$ & $3 \mathrm{~h}$. & $4 \mathrm{~h}$ & $24 \mathrm{~h}$. \\
\hline \multicolumn{7}{|l|}{ Aparência geral } \\
\hline \multicolumn{7}{|l|}{ Frêmito vocal } \\
\hline \multicolumn{7}{|l|}{ Irritabilidade } \\
\hline \multicolumn{7}{|l|}{ Atividade motora } \\
\hline \multicolumn{7}{|l|}{$\begin{array}{l}\text { Redução do Reflexo de } \\
\text { endireitamento }\end{array}$} \\
\hline \multicolumn{7}{|c|}{ Resposta ao aperto de cauda } \\
\hline \multicolumn{7}{|l|}{ Contorção } \\
\hline \multicolumn{7}{|l|}{ Perda da força de agarrar } \\
\hline \multicolumn{7}{|l|}{ Reflexo auricular } \\
\hline \multicolumn{7}{|l|}{ Reflexo corneal } \\
\hline \multicolumn{7}{|l|}{ Respiração } \\
\hline \multicolumn{7}{|l|}{ Tremores finos do corpo } \\
\hline \multicolumn{7}{|l|}{ Tremores grossos do corpo } \\
\hline \multicolumn{7}{|l|}{ Reação de susto } \\
\hline \multicolumn{7}{|l|}{ Convulsões } \\
\hline \multicolumn{7}{|l|}{ Anestesia } \\
\hline \multicolumn{7}{|l|}{ Ptose palpebral } \\
\hline \multicolumn{7}{|l|}{ Enoftamia e exoftalmia } \\
\hline \multicolumn{7}{|l|}{ Straub } \\
\hline \multicolumn{7}{|l|}{ Piloereção } \\
\hline \multicolumn{7}{|l|}{ Defecação (consistência) } \\
\hline Mortes & & & & & & \\
\hline
\end{tabular}

Observações/Comentários: 


\section{* TOXICIDADE SUBCRÔNICA}

O estudo de toxicidade subcrônica dos extratos foi realizado segundo metodologia preconizada por Brito (1994).

Ratos machos e fêmeas Wistar pesando cerca de $150 \mathrm{~g}$, foram divididos em grupos de dez arimais (cinco fêmeas e cinco machos por grupo). Os animais foram aclimatados à temperatura de cerca de $22^{\circ} \mathrm{C}$, com ciclos de 12 horas de claro e escuro; regime alimentar com ração tipo purina e água ad libitum.

Os Extratos Brutos Liofilizados (EBLF e EBLC) foram solubilizados em água, sendo a mesma utilizada como controle, e administrados aos animais via oral, por gavagem, nas doses de $400 \mathrm{mg} / \mathrm{kg}$ e $800 \mathrm{mg} / \mathrm{kg}$, num volume máximo de $1 \mathrm{~mL} / 100 \mathrm{~g}$ de animal, uma vez ao dia, durante 33 dias. $O$ padrão de comportamento dos animais (depressão, excitação, convulsão, esterotipia, piloereção, diarréia, constipação) foi observado diariamente durante o período do experimento.

A toxicidade subcrônica foi avaliada através da determinação de parâmetros bioquímicos e hematológicos (Stevens e Gallo, 1982) e verificação anatomopatológica. A cada 2 dias, durante os 33 dias de tratamento, foram determinados o peso corporal de cada animal e o consumo de água e ração.

As análises hematológicas e bioquímicas foram realizadas no Departamento de Análises Clínicas e Toxicológicas da Faculdade de Ciências Farmacêuticas da Universidade de São Paulo. Realizaram-se as seguintes análises bioquímicas: dosagem de glicose pelo método enzimático colorimétrico, utilizando-se enzimas GOD/POD, quantificadas no espectrofotômetro Hitachi, dosagem de uréia pelo método colorimétrico de acordo com o fabricante (Bayer) em espectrofotômetro Micronal B 380, em cubeta de $1 \mathrm{~cm}$, dosagem de creatinina por uma reação cinética colorimétrica sem desproteinização - reação de Jaffé, de acordo com o fabricante (Bayer) em espectrofotômetro Coleman Jr. IIA modelo 6120 A (USA).

As amostras de sangue dos animais foram coletadas da artéria abdominal com seringa de plástico contendo 500 uL de EDTA 0,2 M, sob anestesia com 
éter etílico.

Os órgãos foram analisados histologicamente na Faculdade de Medicina Veterinária e Zootecnia da USP.

\subsubsection{Avaliação da Atividade Antiulcerogênica}

\section{* LESÃo GÁstRICA AGUDA (ETANOL/HCl)}

O estudo da lesão gástrica aguda foi realizado segundo metodologia preconizada por Mizui e Doteuchi (1983).

Neste ensaio foram utilizados 10 ratos Wistar machos em cada grupo experimental, provenientes do Biotério da Faculdade de Ciências Farmacêuticas - USP, pesando entre 150 e 180 g. Os animais permaneceram em jejum por 24 horas, antes do experimento. Aos animais foram administrados, por via oral, $400 \mathrm{mg} / \mathrm{kg}$ de Extratos Brutos Lioflizados (EBLF e EBLC) e frações (grupos tratados), água ou Tween 80, conforme o solvente utilizado para solubilizar as amostras (grupos controles) e Misoprostol na dose de $100 \mu \mathrm{g} / \mathrm{kg}$, v.o. (grupo de referência). Após 30 minutos, todos os animais receberam $1 \mathrm{~mL} / 100 \mathrm{~g}$ (v.o.) de solução 0,3 $\mathrm{M}$ de $\mathrm{HCl}$ em etanol a $60 \%$ como agente ulcerogênico. Após uma hora, os animais foram mortos por sobre dosagem de anestésico - éter etílico, seus estômagos retirados, abertos ao longo da grande curvatura, lavados com água corrente, prensados entre duas placas de vidro e suas áreas medidas através do programa Image pro plus.

$A$ análise destes resultados foi realizada, considerando os seguintes parâmetros (Gonzalez et al., 2001):

1. Área Total de Lesão Ulcerativa em $\mathrm{mm}^{2}$, calculada pela somatória das áreas de lesão individuais;

2. Área Relativa de Lesão que se refere à porcentagem de área ulcerativa $(p)$ em relação à área total do estômago. Esta 
porcentagem foi transformada em arcoseno pela fórmula: $p^{\prime}=$ arcsen $\checkmark$, para se proceder a análise estatística adequada;

3. Índice de Lesão Ulcerativa (ILU). Para cálculos dos Índices de Lesão Ulcerativa (ILU), as úlceras foram classificadas em três níveis, de acordo com a severidade: nível $1\left(n_{1}\right)$ : úlceras com área menor que 1 $\mathrm{mm}^{2}$; nível $2\left(\mathrm{n}_{2}\right)$ : úlceras com área entre 1 e $3 \mathrm{~mm}^{2}$; e nível $3\left(\mathrm{n}_{3}\right)$ : úlceras com área maior que $3 \mathrm{~mm}^{2}$. Para cada estômago, o ILU foi calculado pela fórmula:

ILU $=1 \times\left(n^{0}\right.$ de úlceras em $\left.n_{1}\right)+2 x\left(n^{0 .}\right.$ de úlceras em $\left.n_{2}\right)+3 x\left(n^{0}\right.$ de úlceras em $\left.n_{3}\right)$

\section{* LESÃo GÁSTRICA SUBCRÔNICA (ÁCIDO ACÉTICO)}

Para a realização do ensaio de úlcera subcrônico foram utilizados grupos de 8 animais (Ratos machos Wistar), mantidos em jejum por 24 horas, com livre acesso a água. Após indução de úlcera com ácido acético, os animais foram tratados por via oral, durante 8 dias, com os Extratos Brutos Liofilizados (EBLF e EBLC).

O experimento seguiu a técnica preconizada por Takagi et al. (1969), de acordo com a seguinte seqüência:

$>$ aos animais submetidos a anestesia com éter, procedeu-se uma incisão na região abdominal e, no estômago parcialmente exposto, onde foram injetados $0,05 \mathrm{~mL}$ de ácido acético a $30 \%$, abaixo da serosa;

$>$ no segundo dia após a cirurgia, foram administrados aos diferentes grupos (Controle, Tratados e Referência), por via oral, água, extratos brutos de Caesalpinia ferrea, na dose de $200 \mathrm{mg} / \mathrm{kg}$ ou $400 \mathrm{mg} / \mathrm{kg}$, ou cimetidina $(100 \mathrm{mg} / \mathrm{kg})$;

> os animais foram mortos após 8 dias, e verificou-se o tamanho das ulcerações segundo os parâmetros descritos anteriormente (ATL e ARL). 


\subsubsection{Avaliação da Atividade Antioxidante}

A atividade antioxidante in vitro foi medida através da inibição da autoxidação de homogeneizado de cérebro.

Este modelo experimental foi utilizado para os Extratos Brutos Liofilizados de Folhas (EBLF) e Caules (EBLC) de $C$. ferrea. Os extratos foram solubilizados em etanol $70 \%$ e as diluições foram efetuadas com etanol $35 \%$. O etanol 35\% foi utilizado como controle.

Para a obtenção do homogeneizado de cérebro foram utilizados ratos machos adultos Wistar com massa corpórea entre 200-250 g. Os animais foram anestesiados com éter e então submetidos à laparotomia e o cérebro perfundido, através do coração, com tampão $\mathrm{NaCl} 140 \mathrm{mM}$ fosfato $40 \mathrm{mM}, \mathrm{pH}$ 7,4 a 4 O C.

Os cérebros foram homogeneizados em quatro vezes seu peso no tampão acima e centrifugados por 15 minutos a $3000 \mathrm{rpm}$, a 4 o $\mathrm{C}$. $\mathrm{O}$ sobrenadante foi imediatamente diluído em três vezes o seu volume com o mesmo tampão (Stocks et al., 1974) e conservado em gelo até o final do experimento. Foram transferidos $3 \mathrm{~mL}$ desta solução para erlenmeyers de $25 \mathrm{~mL}$ e acrescentados 50 ụL da amostra (solução do extrato).

Para tempo zero foi reservado $1 \mathrm{~mL}$ da diluição acima e acrescentado $1 \mathrm{~mL}$ de ácido tricloroacético (TCA) a 5\% (To). O restante foi incubado por uma hora, a $37{ }^{\circ} \mathrm{C}$, sob agitação constante. Após 1 hora, foi retirado $1 \mathrm{~mL}$ da diluição incubada e acrescentado $1 \mathrm{~mL}$ de TCA $5 \%$ (T1).

Posteriormente, as amostras, tanto To como T1, foram centrifugadas por 15 minutos a 3000rpm. De todas as amostras foi retirado $1 \mathrm{~mL}$ do sobrenadante e a este acrescentado $1 \mathrm{~mL}$ de solução de ácido tiobarbitúrico a $0,67 \%$ em água (TBA). Essa mistura foi levada a aquecimento em banho de água fervente por 20 minutos, seguido de um resfriamento em banho de gelo pelo mesmo intervalo de tempo. Após este período, esta mistura foi mantida por 20 minutos em temperatura ambiente e em seguida foi realizada a leitura da inibição da autoxidação de homogeneizado de cérebro em espectrofotômetro a 535nm. 
Homogeneizados de cérebro, quando incubados em condições de oxigenação e temperatura, sofrem peroxidação espontânea que pode ser avaliada quer pela produção de malonildialdeído (MDA), através de medidas de TBARS (thiobarbituric acid reactants substance), ou pela medida de quimioluminescência. Dessa forma, as medidas de TBARS foram determinadas de acordo com Fee e Teitelbaum (1972) e realizadas na presença de diferentes concentrações dos extratos brutos liofilizados $(0,05$; 0,$025 ; 0,0125 ; 0,00625$ e $0,003125 \mathrm{mg} / \mathrm{mL}$ ) suspensos em tampão fosfato/salina $(\mathrm{pH}=7,4)$. A capacidade antioxidante ( $\mathrm{CAOx}$ ) foi calculada em porcentagem relativamente a controles aos quais não se adicionam extratos.

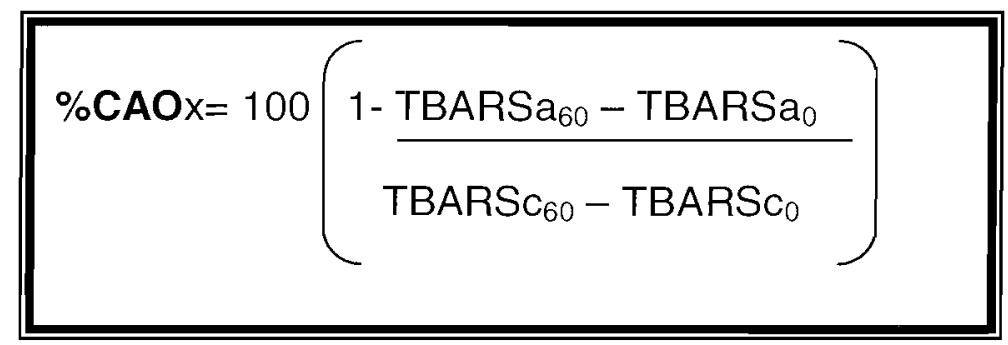

Onde:

$\% \mathrm{CAOx}=$ Capacidade Antioxidante medida em porcentagem;

TBARSa $_{60}=$ TBARS da amostra com a adição de extrato após 60 minutos de incubação a $37^{\circ} \mathrm{C}$ sob banho-maria com agitação;

TBARSa $a_{0}=$ TBARS da amostra com a adição de extrato antes da incubação;

TBARSC $_{60}=$ TBARS da amostra sem a adição de extrato após 60 minutos de incubação (controle);

TBARS $_{0}=$ TBARS da amostra sem a adição de extrato antes da incubação. 


\subsubsection{Avaliação da Atividade Cicatrizante}

O ensaio com controle (água) e Extratos Brutos Liofilizados de Folhas (EBLF) e Caule (EBLC) de Caesalpinia ferrea foi realizado com 10 ratos Wistar machos (150-200 g), para cada grupo. Cada arimal, anestesiado com éter etílico, foi depilado na região dorsal, sofrendo uma incisão realizada com "punch" (trepano para extração de córnea) de $1 \mathrm{~cm}$ de diâmetro (Mukherjee et al., 2000). Os animais foram mantidos em gaiolas individuais, sendo adicionado em cada bebedouro Anador $^{\circledR}$, na proporção de 6 gotas para $400 \mathrm{~mL}$. Povidine ${ }^{\circledast}$ foi utilizado como antisséptico no momento da incisão e no material cirúrgico. O animais foram tratados topicamente com água (grupo controle) e extratos brutos liofilizados (a 15\% em água). Todas as aplicações foram realizadas uma vez ao dia, durante 14 dias, com o auxílio de uma pipeta de $1 \mathrm{~mL}$.

No $2^{\circ}, 4^{\circ}, 6^{\circ}, 8^{\circ}, 10^{\circ}, 12^{\circ}$ e $14^{\circ}$ dias, as feridas foram avaliadas quantitativamente. As medidas foram determinadas através do programa Image-Pro Plus, após terem sido copiadas.

Os tecidos das feridas dos animais controle e tratados foram analisados histologicamente, em animais mortos no $7^{\circ}$ e $15^{\circ}$ dia. Para tanto, a região onde ocorreu a cicatrização foi novamente depilada, separada através de tesoura cirúrgica e colocada em solução de Formol a 10\%. As peças histológicas foram obtidas por desidratação, diafanização e imersão em parafina. O estudo morfológico foi realizado nas peças, cortadas em micrótomo (5 micrômetros de espessura) e utilizada a técnica de coloração pela hematoxilina de Harris e eosina (H\&E), basicamente como descrito por Luna (1968). Utilizou-se também, a coloração denominada Picro sírus, para evidenciar fibras colágenas (Junqueira et al., 1979).

Os tecidos foram analisados em microscópio óptico e as fotos realizadas em câmara acoplada ao microscópio. 


\subsection{Análise Estatística}

Os resultados dos ensaios biológicos foram analisados por meio de Análise de Variância, seguida do Teste Tukey para análise de dados paramétricos ou Kruskal Wallis (Dunn) para dados não paramétricos, com nível de significância de $5 \%(p<0.05)$. 


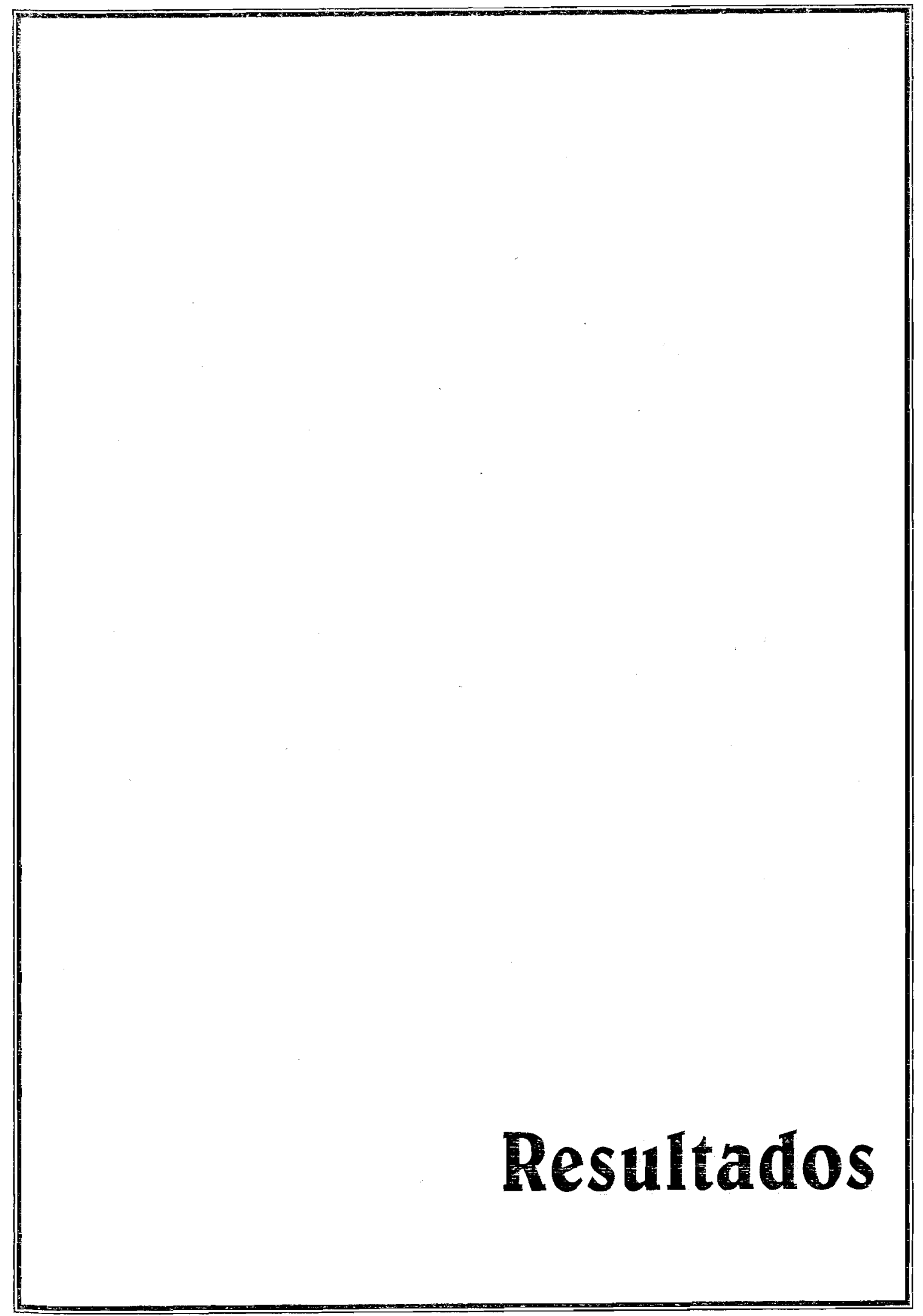




\section{Resultados}

\subsection{Descrição Macroscópica e Microscópica}

- Descrição geral da planta

Árvore com tronco liso, cinéreo, provido de manchas esbranquiçadas, geralmente alongadas longitudinalmente, pode alcançar até $30 \mathrm{~m}$ de altura e $50-80 \mathrm{~cm}$ de diâmetro (Figura $3 A-D$ ). Os ramos terminais de 5 a $20 \mathrm{~mm}$ de diâmetro apresentam-se amarronzados e glabros.

\section{Folha}

- Descrição Macroscópica

As folhas são bipinadas, paripinadas, opostas, medindo $14-20 \mathrm{~cm}$. Os folíolos são opostos a subopostos, sésseis, $6-8$ jugados, lâmina de 0.5 a $0.7 \mathrm{~cm}$ de largura e 0.9 a $1.3 \mathrm{~cm}$ de comprimento, obovada, de ápice retuso a obtuso, de base inequilátera, margem inteira, verde opalescente nas 2 faces, venação curvivenia, com nervura central ligeiramente impressa na face superior e algo saliente na face inferior (Figura 3B-C). As nervuras secundárias, em número de 7 a 8 pares, são opostas ou subopostas, pouco proeminentes na face abaxial. Pulvinos e pulvínulos são evidentes.

As folhas frescas são inodoras. Quando transformadas em droga, mostram-se papiráceas, parcialmente recurvadas, com densidade menor que a água, odor adocicado e sabor amargo e adstringente.

- Descrição Microscópica

A epiderme dos folíolos, em corte transversal, apresenta-se uniestratificada, constituída por células de contorno aproximadamente retangular, alongadas no sentido periclinal, revestidas por cutícula lisa. $\mathrm{Na}$ 
região da nervura mediana, as células evidenciam-se aproximadamente arredondadas. As paredes periclinais externas das células epidérmicas são espessadas em ambas as faces da lâmina e, na face abaxial, observa-se convexidade evidente. Em vista frontal, o contorno mostra-se sinuoso. A sinuosidade revela-se acentuada na face abaxial (Figura 4). Tricomas glandulares pluricelulares, sésseis, localizados em ligeiras depressões, são observados, algumas vezes, nesta face. Estas estruturas não apresentaram espaços conspícuos (Figura 5A-B). Seu conteúdo adquiriu coloração laranja intensa, quando tratado com Sudam III (Figura 5C).

A folha é hipoestomática (Figura 6 A-D). Os estômatos, que ocorrem no mesmo nível das demais células epidérmicas, apresentam-se circundados por 2 a 4 células, predominando os paracíticos (Figura 6 C-D).

O mesofilo é constituído de 4 a 5 camadas de parênquima paliçádico. Algumas destas células, junto às duas faces, sofrem divisões periclinais, sendo que as células mais externas normalmente contém drusas de oxalato de cálcio (Figura $7 A, C$ ). Os feixes vasculares de menor calibre apresentam bainha cristalífera (Figura $7 B$ ). No mesofilo encontram-se freqüentemente drusas e raros cristais prismáticos (Figura $7 C$ ), além de idioblastos com conteúdo marrom. Estes últimos, após tratamento com reativo contendo solução de ácido sulfúrico adquiriram forma cristalina acicular.

A nervura mediana é aproximadamente plano-convexa (Figuras $4 A, 5 A$, $7 A$ e $8 A$ ). As células epidérmicas que recobrem esta região são comparativamente menores, observando-se, em seguida, 2 a 3 camadas de parênquima paliçádico. Junto à face abaxial, encontram-se células arredondadas de paredes delgadas, delimitando meatos.

No xilema, os elementos de vaso estão dispostos em fileiras radiais e separados por 1 a 2 fileiras de células parenquimáticas. No floema observa-se grande número de drusas. Externamente a esta região, observa-se calota fibrosa conspícua (Figuras 4A, 7A).

Fenólicos são abundantes nas células paliçádicas mais externas, principalmente junto à face adaxial (cloreto férrico) (Figura 8). 


\section{Descrição Macroscópica}

A superfície externa do caule de menor diâmetro apresenta coloração marrom com freqüentes lenticelas de forma lenticular (Figura $3 E-F$ ). No caule de 1-2 mm de diâmetro, em secção transversal e longitudinal, observada à vista desarmada ou com auxílio de lupa, encontram-se quatro regiões de coloração distinta, onde pode-se destacar a medula e poros difusos.

O caule, quando transformado em droga apresenta-se inodoro, com densidade maior que a água, sabor amargo e adstringente.

\section{- Descrição Microscópica}

No caule com cerca de 1-2 mm de diâmetro, o súber é constituído por células espessadas, suberizadas, de contorno aproximadamente retangular, alongadas no sentido periclinal, intercaladas com faixas de células de contorno quadrangular. Nesta região podem ser observadas de 5 a 20 camadas de células (Figura 9).

A feloderme é constituída de até 10 camadas de células espessadas de paredes celulósicas, achatadas, alongadas no sentido tangencial. Nesta região observa-se grande número de drusas e cristais prismáticos (Figura $9 A, B, 11$ ).

O parênquima cortical é constituído de células de diferentes formas e tamanhos delimitando meatos. Nesta região observa-se freqüentemente drusas e raros cristais prismáticos (Figura 9A).

Externa à região floemática, encontra-se anel esclerenquimático contínuo, constituído, predominantemente de fibras, intercaladas com esclereídes providos de pontoações simples e ramificadas (Figura 9A, 10 e 11A).

O floema é constituído de elementos de condução e parênquima. Os raios floemáticos formados por 1-3 células em largura contêm abundantes drusas e raros cristais prismáticos (Figura 11A,B).

O xilema apresenta elementos de vasos geralmente arredondados, 
solitários e/ou múltiplos radiais, em arranjo difuso. No material dissociado, podem ser observadas drusas, elementos de condução com espessamento espiralado, reticulado e providos de pontoações areoladas ou guarnecidas (Figura 12).

Nos caules de diâmetro menor que $2 \mathrm{~mm}$, observa-se no xilema um parênquima axial em faixas tangenciais descontínuas irregularmente espaçadas e arranjo paratraqueal escasso a vasicêntrico, já em caules de diâmetro maior ( $2 \mathrm{~mm}$ ) há predominância do parênquima em faixas contínuas.

Raios geralmente unisseriados e parênquima radial heterogêneo, constituido de evidentes células procumbentes e quadradas.

O parênquima medular é formado de células de diferentes tamanhos delirnitando meatos (Figura 12A) contendo ocasionais cristais prismáticos e freqüentes amiloplastos. 

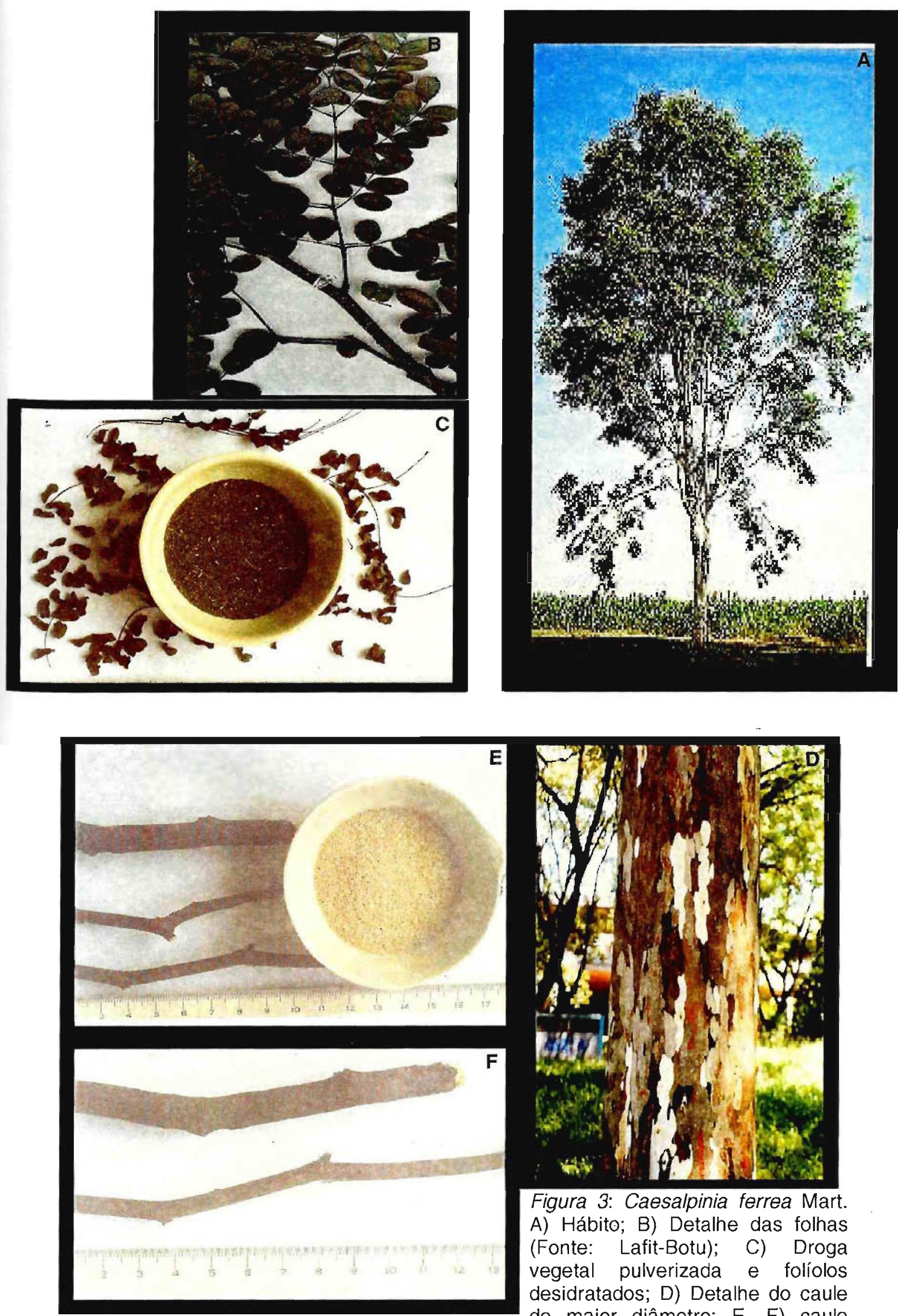

Figura 3: Caesalpinia ferrea Mart. A) Hábito; B) Detalhe das folhas (Fonte: Lafit-Botu); C) Droga vegetal pulverizada e folíolos desidratados; D) Detalhe do caule de maior diâmetro; E, F) caule fragmentado e pulverizado. 

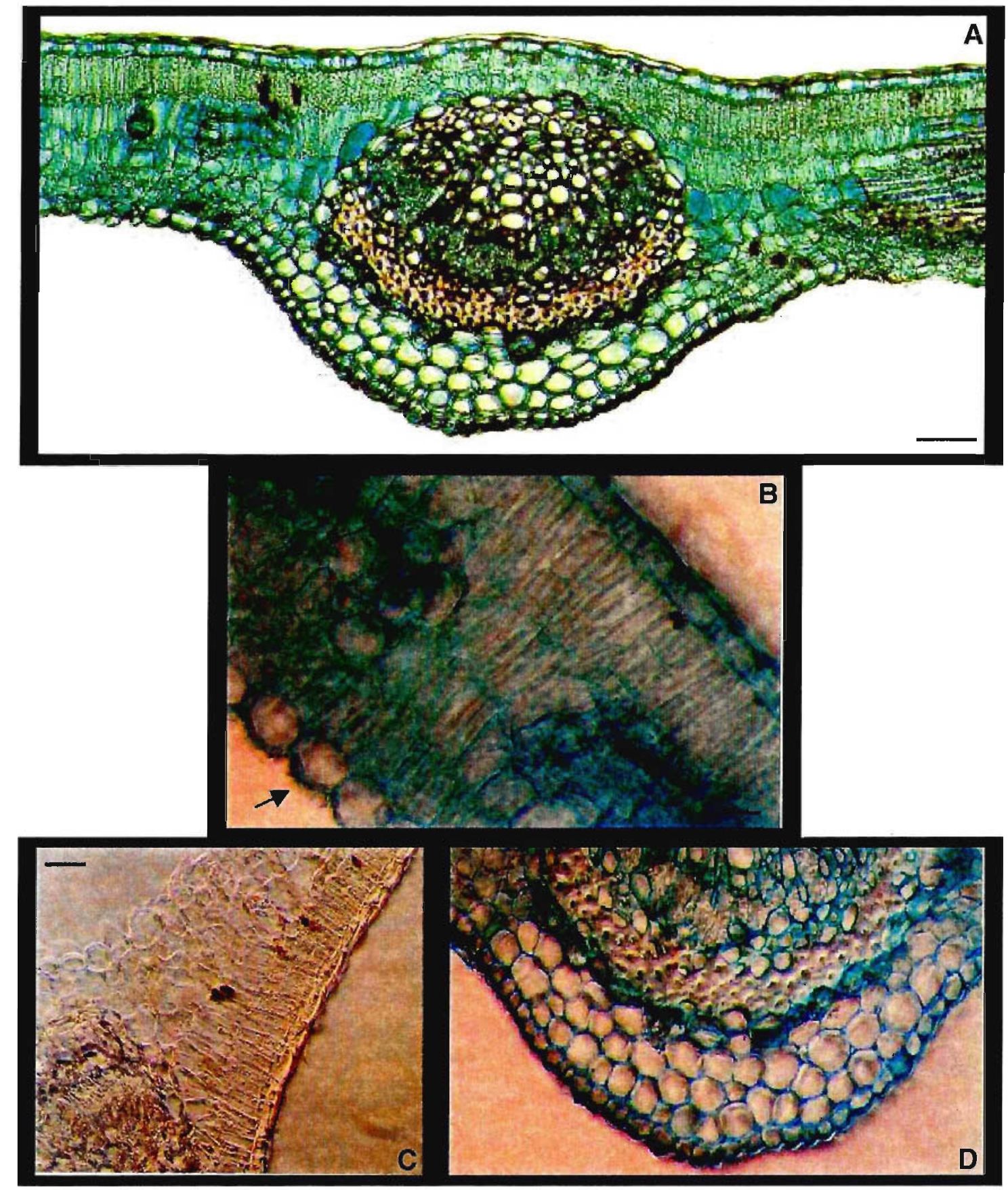

Figura 4: Corte); B) Detalhe, destacando a forma das células

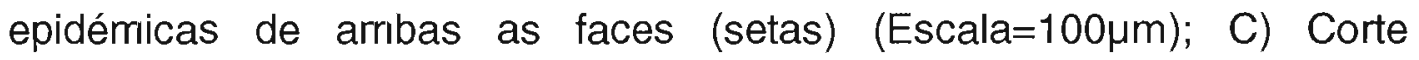
descolorido evidenciando conteúdo castanho nas células parenquimáticas (Escala $=100 \mu \mathrm{m})$; D) Destaque ao contorno das células epidérmicas da face abaxial na região da nervura mediana (Escala $=20 \mu \mathrm{m}$ ). 


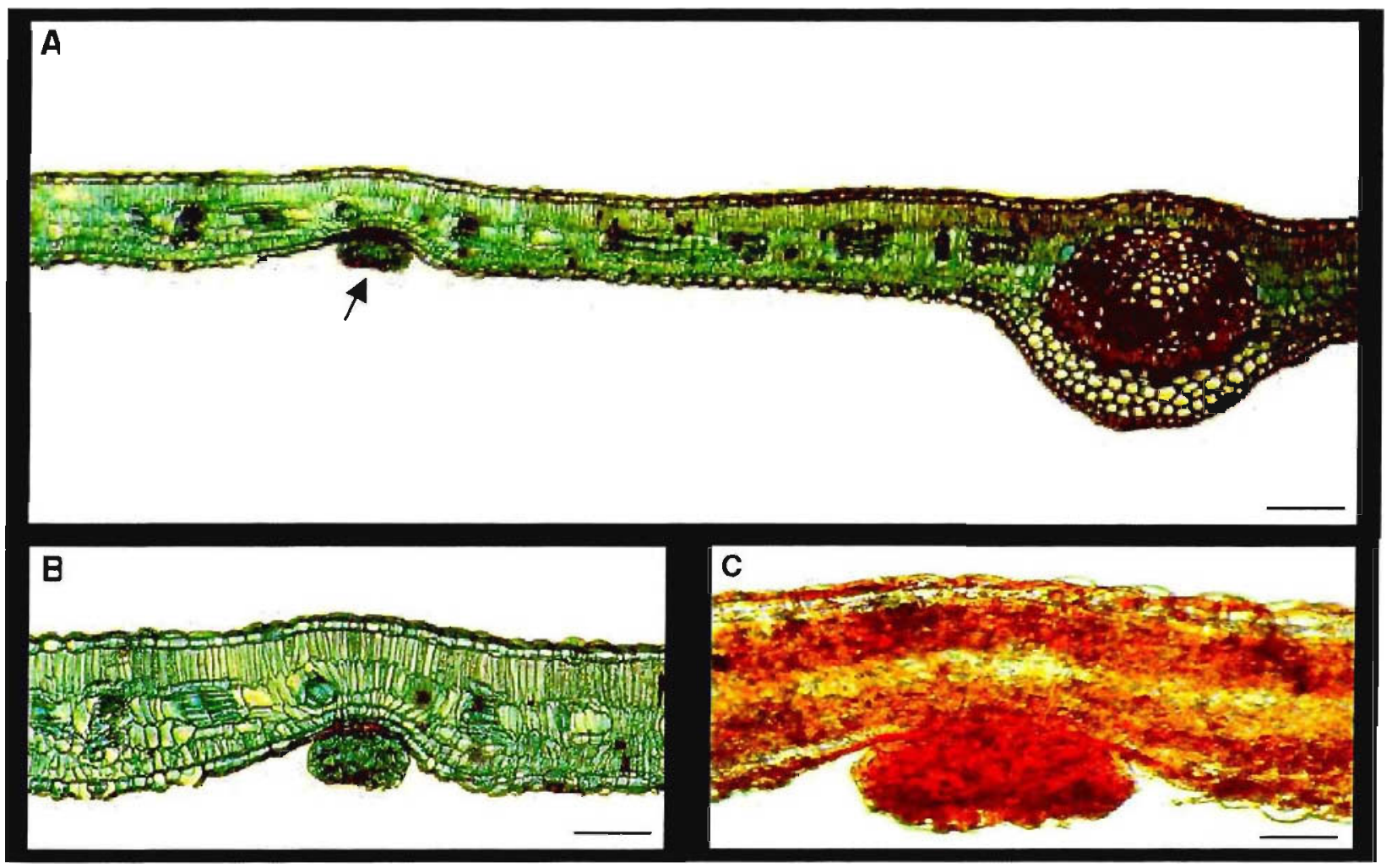

Figura 5: Cortes transversais da folha de $C$. ferrea Mart. A) Visão geral, com destaque ao tricoma glandular (seta) (Escala=100 $\mu \mathrm{m}$ ); B) Detalhe, destacando mesofilo e tricoma glandular (Escala $=40 \mu \mathrm{m}$ ); C) Detalhe do tricoma glandular corado com Sudam III (Escala=20 $\mu \mathrm{m})$. 

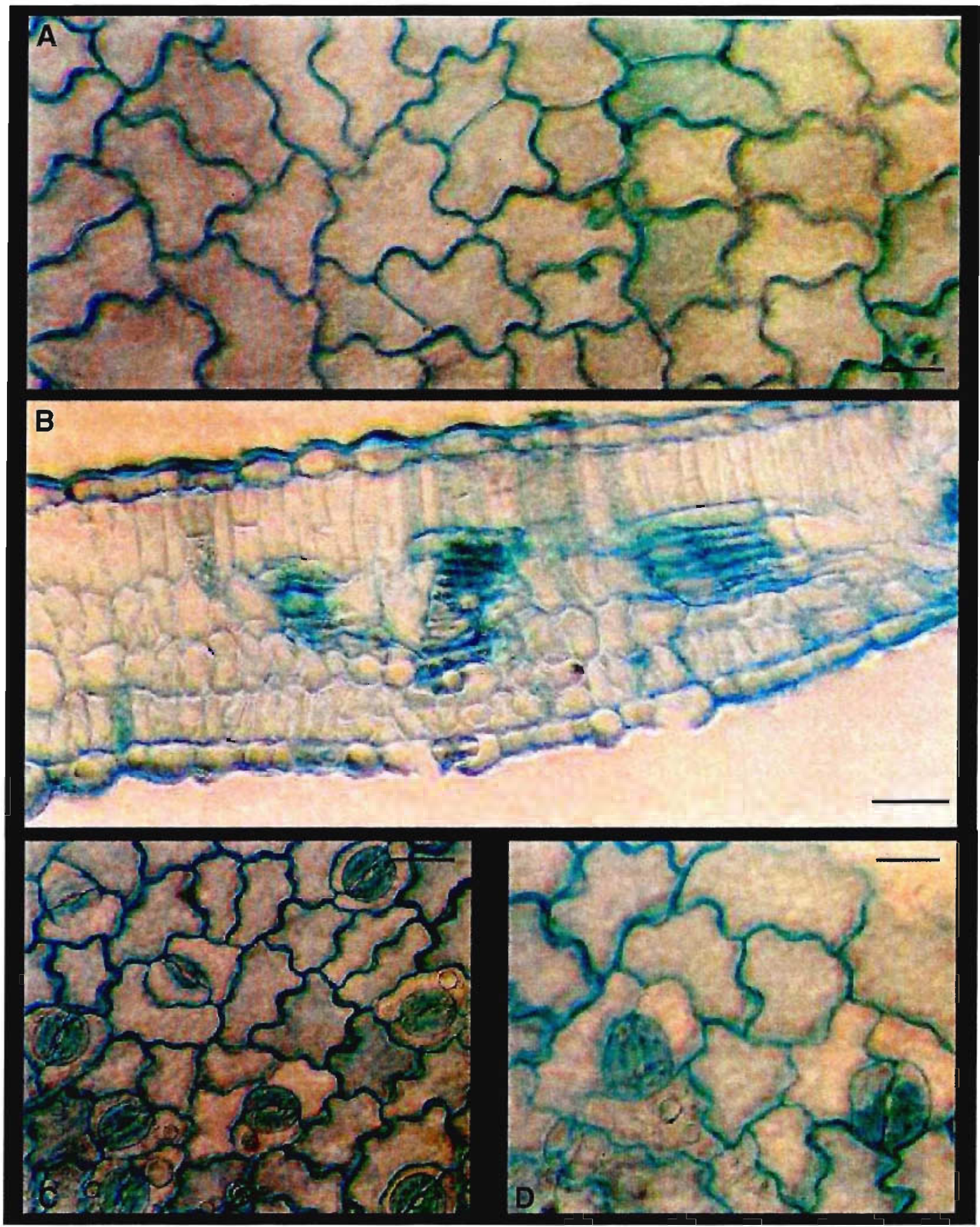

Figura 6: Cortes paradérmicos (A,C e D) e transversais $(B)$ da

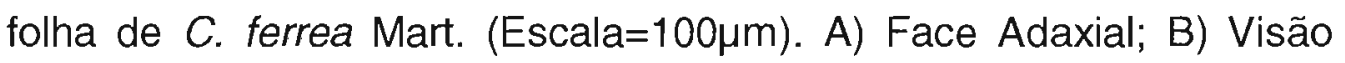
geral; C, D) Destaque células epidérmicas e estômatos com 2 a 3 células subsidiárias. 


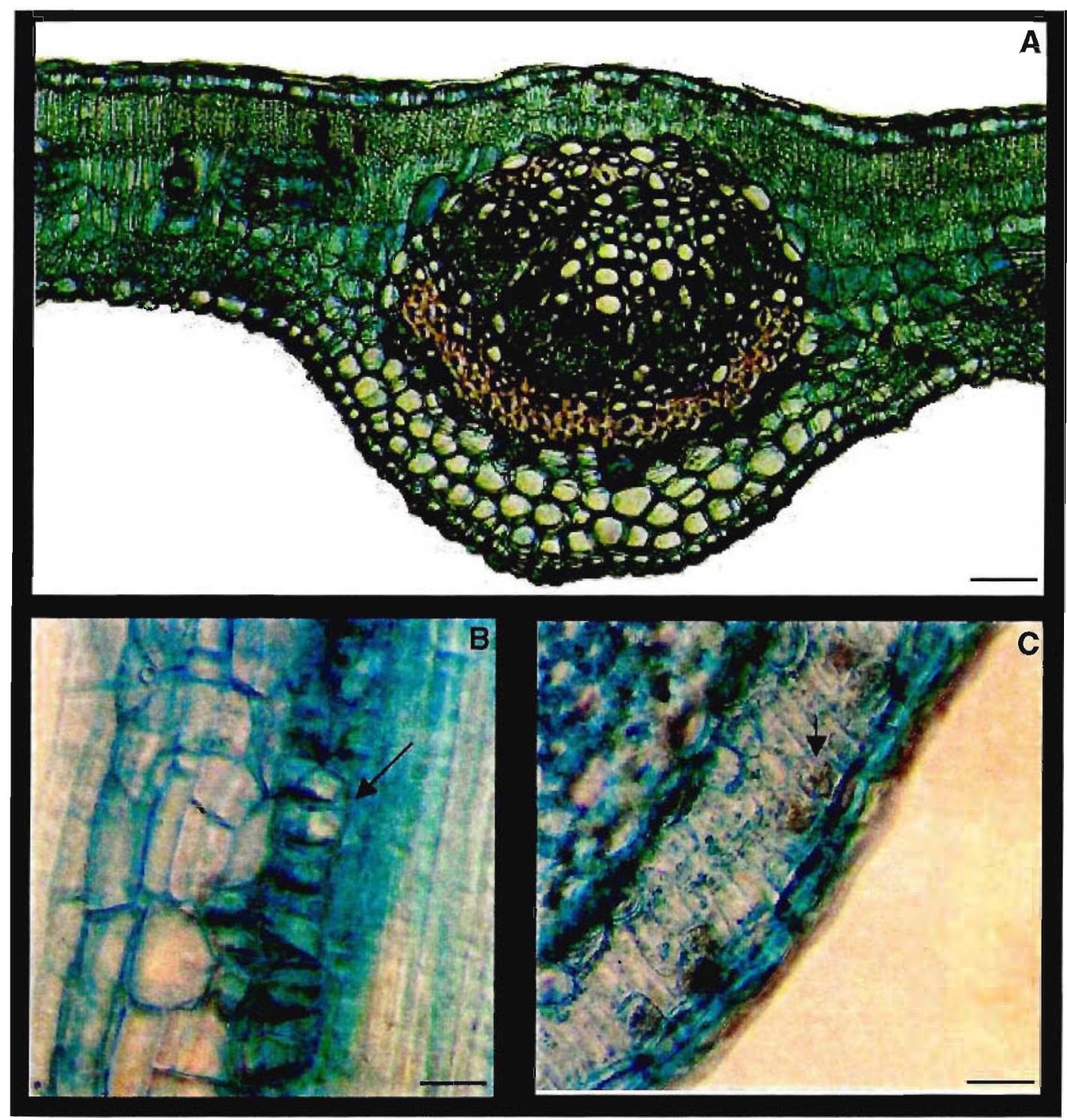

Figura 7: Cortes transversais da folha de C. ferrea Mart. A) Visão geral (Escala $=40 \mu \mathrm{m})$; B) Detalhe da bainha cristalífera (seta) (Escala $=100 \mu \mathrm{m}) ; \mathrm{C})$ Detalhe de cristais de oxalato de cálcio, especialmente drusas, no parênquima paliçádico (seta) (Escala=100 $\mu \mathrm{m}$ ). 


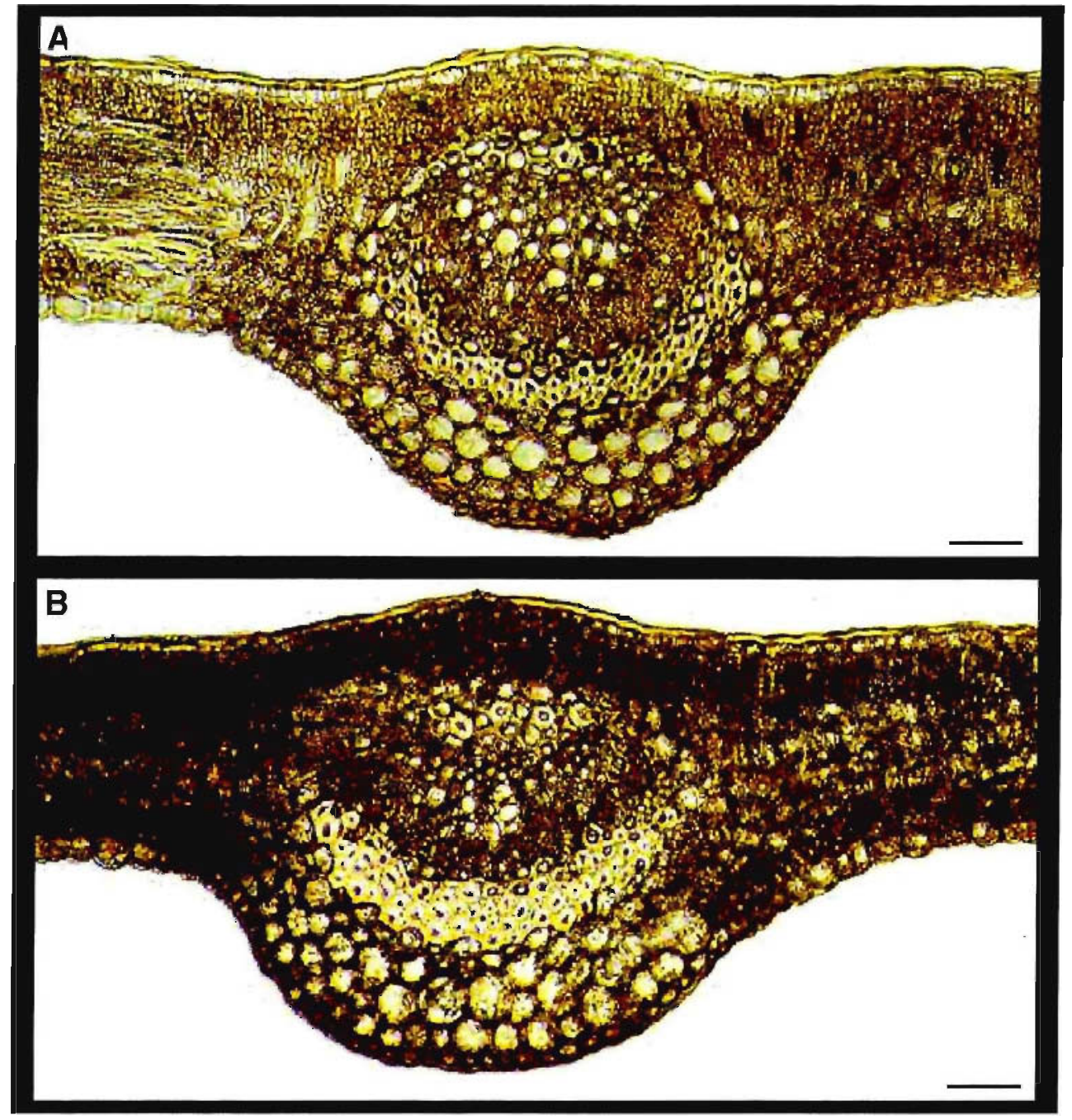

Figura 8: Cortes transversais da folha de C. ferrea Mart. (Escala $=40 \mu \mathrm{m})$. A) Visão geral do corte com cor natural; B) Corte tratado com $\mathrm{FeCl}_{3}$, evidenciando maior concentração de fenólicos nas células paliçádicas mais externas. 

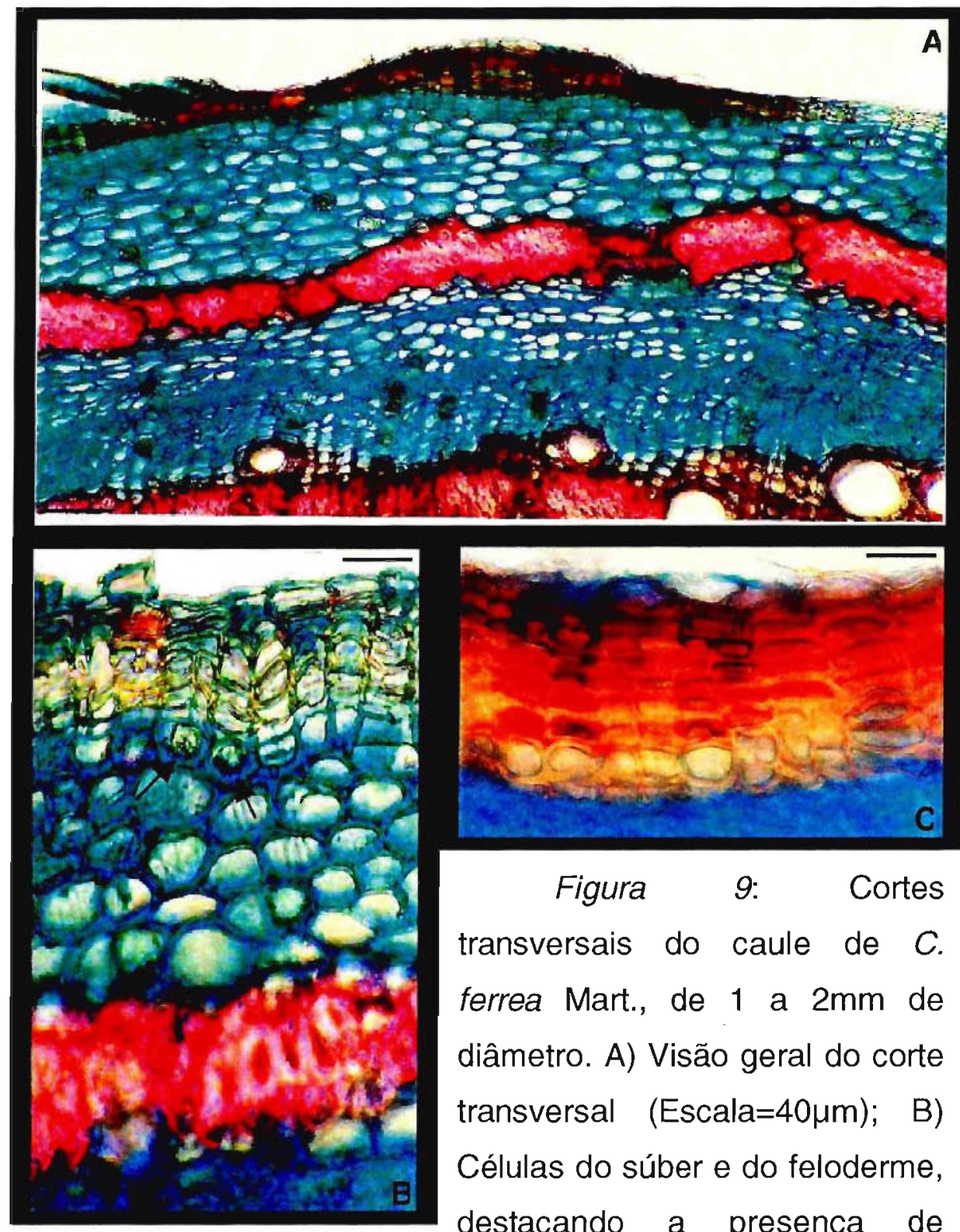

Figura

9: $\quad$ Cortes

transversais do caule de $C$. ferrea Mart., de 1 a $2 \mathrm{~mm}$ de diâmetro. A) Visão geral do corte transversal (Escala $=40 \mu \mathrm{m}) ; \quad B)$ Células do súber e do feloderme, destacando a presença de drusas na feloderme (setas) (Escala $=10 \mu \mathrm{m}) ; \mathrm{C}$ ) Detalhe das células espessadas do súber (Escala $=10 \mu \mathrm{m}$ ). 

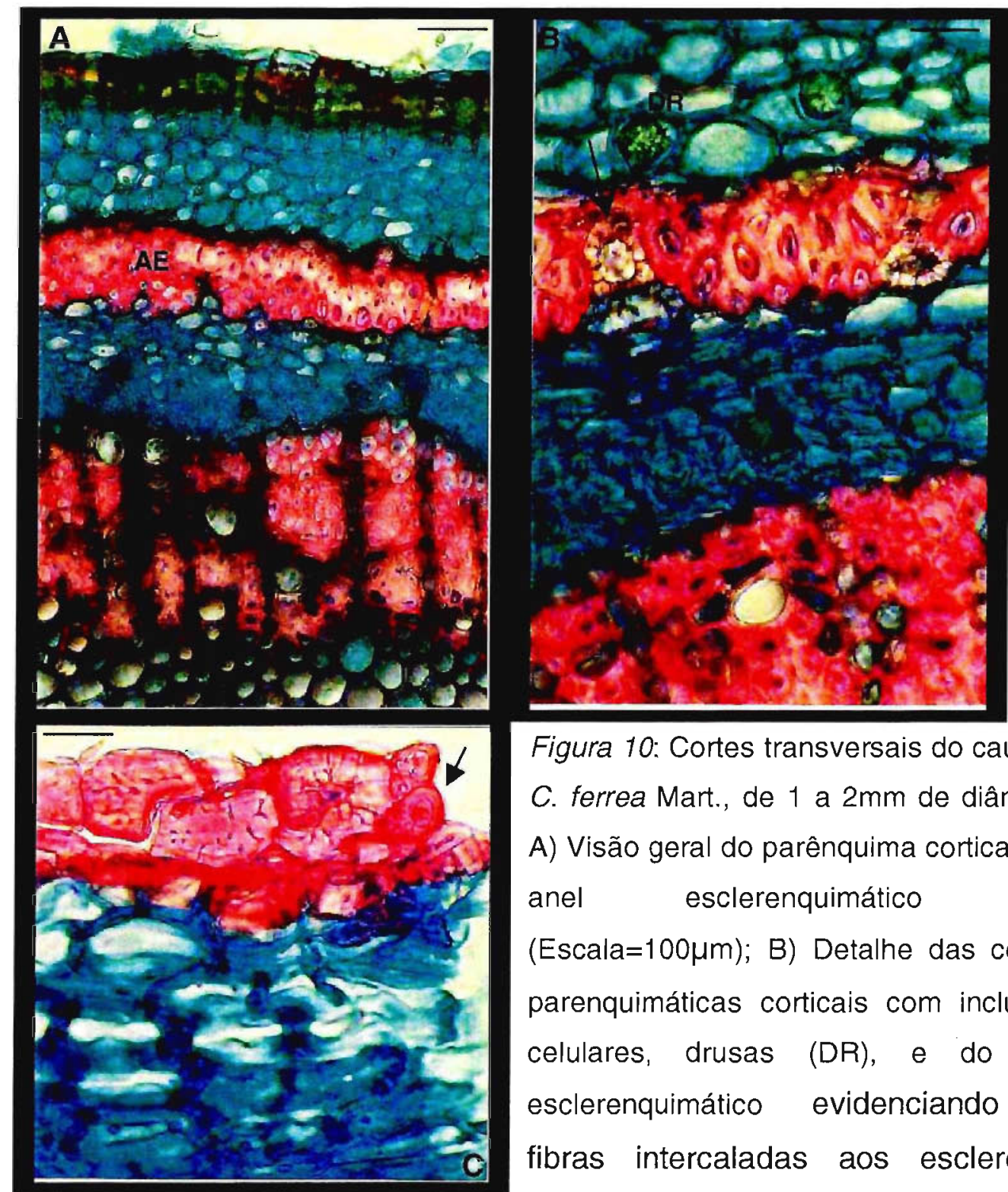

Figura 10: Cortes transversais do caule de C. ferrea Mart., de 1 a $2 \mathrm{~mm}$ de diâmetro. A) Visão geral do parênquima cortical e do anel esclerenquimático (AE) (Escala $=100 \mu \mathrm{m})$; B) Detalhe das células parenquimáticas corticais com inclusões celulares, drusas (DR), e do anel esclerenquimático evidenciando as fibras intercaladas aos esclereides (seta) (Escala $=10 \mu \mathrm{m}) ; \mathrm{C}$ ) Detalhe das fibras intercaladas (seta) aos esclereídes no anel esclerenquimático (Escala $=10 \mu \mathrm{m})$. 


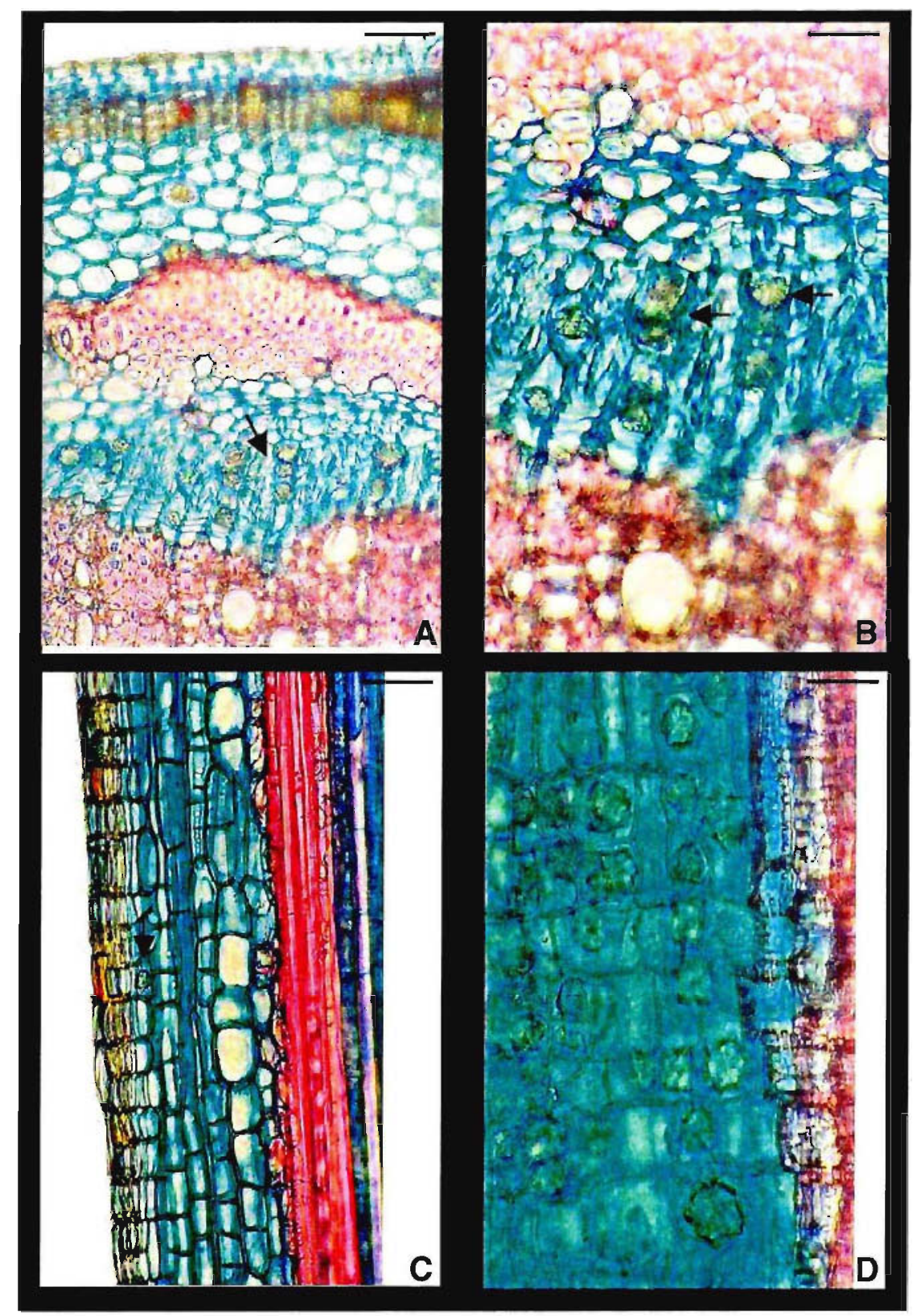

Figura 11: Cortes transversais $(\mathrm{A}, \mathrm{B})$ e longitudinais $(C, D)$ do caule de $C$. ferrea Mart., de 1 a $2 \mathrm{~mm}$ de diâmetro. A) Visão geral dos raios floemáticos com drusas (seta) (Escala=20 $\mu \mathrm{m}$ ).; B, D) Detalhe da região floemática com inúmeras drusas (setas) (Escala $=10 \mu \mathrm{m})$; C) Detalhe das células da feloderme, destacando a presença de inclusões celulares, drusas (seta) $($ Escala $=20 \mu \mathrm{m})$. 


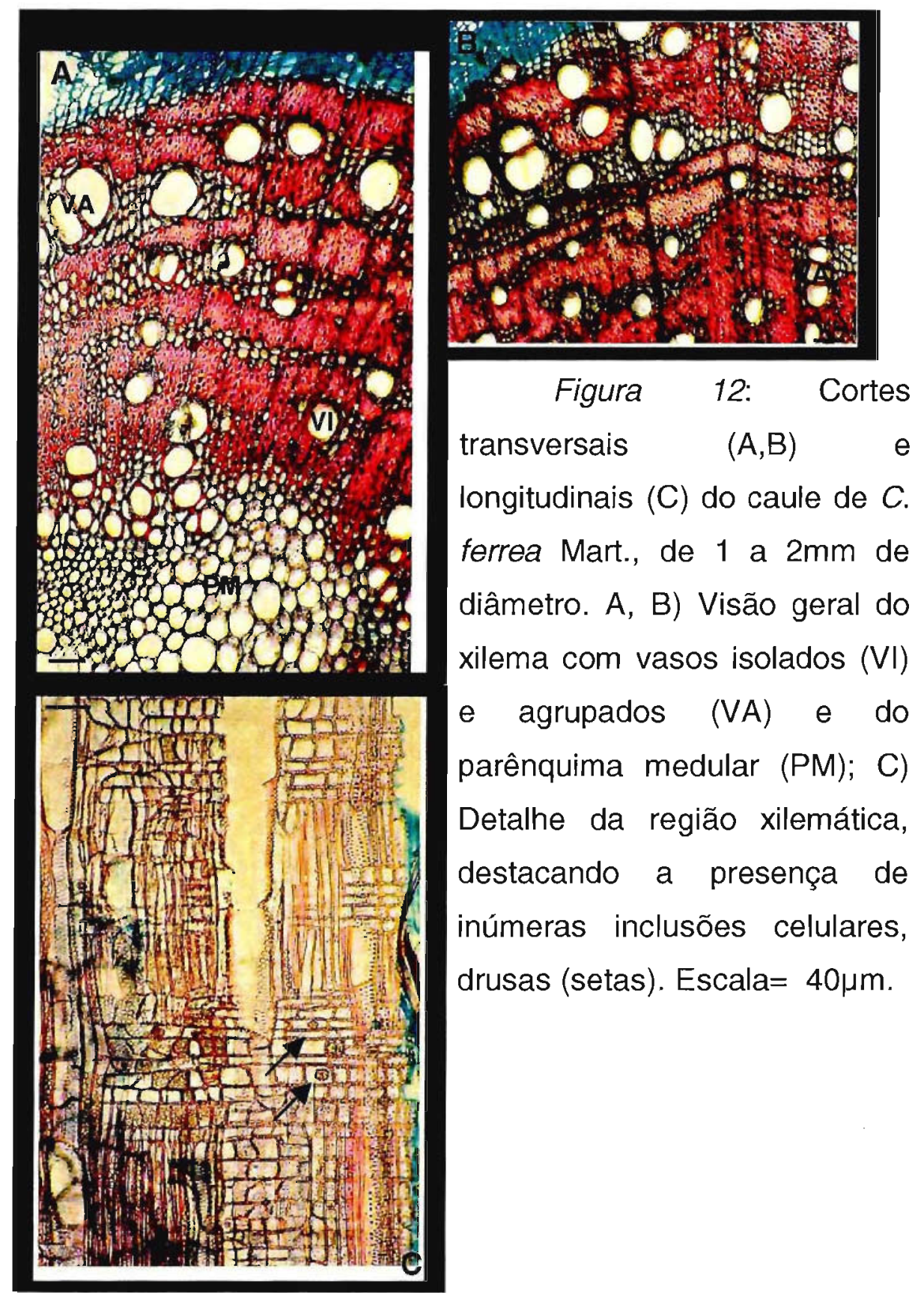


5.2. Triagem Fitoquímica.

Tabela 2: Triagem Fitoquímica realizada com o pó da droga e com o extrato bruto liofilizado de caule (DC, EBLC) e das folhas (DF, EBLF), respectivamente, de Caesalpinia ferrea Mart.

\begin{tabular}{|c|c|c|c|c|c|}
\hline \multirow[t]{2}{*}{ Grupo Químico } & \multirow{2}{*}{$\begin{array}{c}\text { Reação de } \\
\text { Caracterização }\end{array}$} & \multicolumn{4}{|c|}{ Resultados } \\
\hline & & $D C$ & $E B L C$ & $D F$ & $E B L F$ \\
\hline \multirow[t]{4}{*}{ - Alcalóides } & Bertrand & $(-)$ & $(-)$ & $(-)$ & $(-)$ \\
\hline & Bouchardat & $(-)$ & $(-)$ & $(-)$ & $(-)$ \\
\hline & Dragendorff & $(-)$ & $(-)$ & $(-)$ & $(-)$ \\
\hline & Mayer & $(-)$ & $(-)$ & $(-)$ & $(-)$ \\
\hline - Antraderivados & Bornträger & $(-)$ & $(-)$ & $(+)$ & $(+)$ \\
\hline - Cumarinas & $\mathrm{HCl} / \mathrm{Cloreto}$ férrico & $(-)$ & $(+)$ & $(+)$ & $(+)$ \\
\hline \multirow[t]{4}{*}{ - Glicósidos Cardiotônicos } & Liebermann- Burchard & $(+)$ & $(+)$ & $(+)$ & $(+)$ \\
\hline & Keller-Killiani & $(-)$ & $(-)$ & $(-)$ & $(-)$ \\
\hline & Kedde & $(-)$ & $(-)$ & $(-)$ & $(-)$ \\
\hline & Baljet & $(-)$ & $(-)$ & $(-)$ & $(-)$ \\
\hline
\end{tabular}


- Flavonóides

Cloreto de Alumínio

$(+) \quad(+)$

$(+) \quad(+)$

Shinoda

(+) (+)

$(+) \quad(+)$

Hidróxidos

$(+) \quad(+)$

$(+) \quad(+)$

alcalinos

\begin{tabular}{|c|c|c|c|c|c|}
\hline - Taninos & Sais de Ferro & $(+)$ & $(+)$ & $(+)$ & $(+)$ \\
\hline & Acetato de chumbo & $(+)$ & $(+)$ & $(+)$ & $(+)$ \\
\hline & Acetato de cobre & $(+)$ & $(+)$ & $(+)$ & $(+)$ \\
\hline & Alcalóides (quinina) & $(+)$ & $(+)$ & $(+)$ & $(+)$ \\
\hline & Gelatina & $(+)$ & $(+)$ & $(+)$ & $(+)$ \\
\hline \multirow[t]{2}{*}{ - Saponina } & Espuma & $(-)$ & $(-)$ & $(+)$ & $(+)$ \\
\hline & Hemólise & $(-)$ & $(-)$ & $(-)$ & $(-)$ \\
\hline - Óleo Essencial & Microdestilação & $(-)$ & $(-)$ & $(-)$ & $(-)$ \\
\hline
\end{tabular}

Legenda: (+) Reação Positiva; (-) Reação Negativa. 
5.2. Quantificação de Taninos nas Drogas Vegetais e nos Extratos Brutos Liofilizados.

Tabela 3: Teor de Taninos (\%) nas drogas vegetais de caule e de folha de Caesalpinia ferrea Mart e nos seus respectivos extratos brutos liofilizados.

\begin{tabular}{lcc}
\hline & \multicolumn{2}{c}{$\%$ de taninos } \\
\hline Folha & Droga Vegetal & Extrato Bruto Liofilizado \\
& 7,13 & 23,95 \\
& 2,26 & 11,77 \\
\hline
\end{tabular}

5.3. Quantificação de Flavonóides nas Drogas Vegetais e nos Extratos Brutos Liofilizados.

Tabela 4: Teor de Flavonóides (\%) nas drogas vegetais de caule e de folha de Caesalpinia ferrea Mart e nos seus respectivos extratos brutos liofilizados.

\begin{tabular}{ccc}
\hline & \multicolumn{2}{c}{$\%$ de flavonóides } \\
\hline Folha & Droga Vegetal & Extrato Bruto Liofilizado \\
& 0,0095 & 0,0260 \\
& 0,0001 & 0,0017 \\
\hline
\end{tabular}




\subsection{Perfil Cromatográfico}

O perfil cromatográfico foi definido para o extrato bruto liofilizado e para as frações (clorofórmica, acetato de etila, etanólica 100\% e etanólica $50 \%$ ) de caule e folha de $C$. ferrea,nos diferentes sistemas descritos no item 4.5.2.

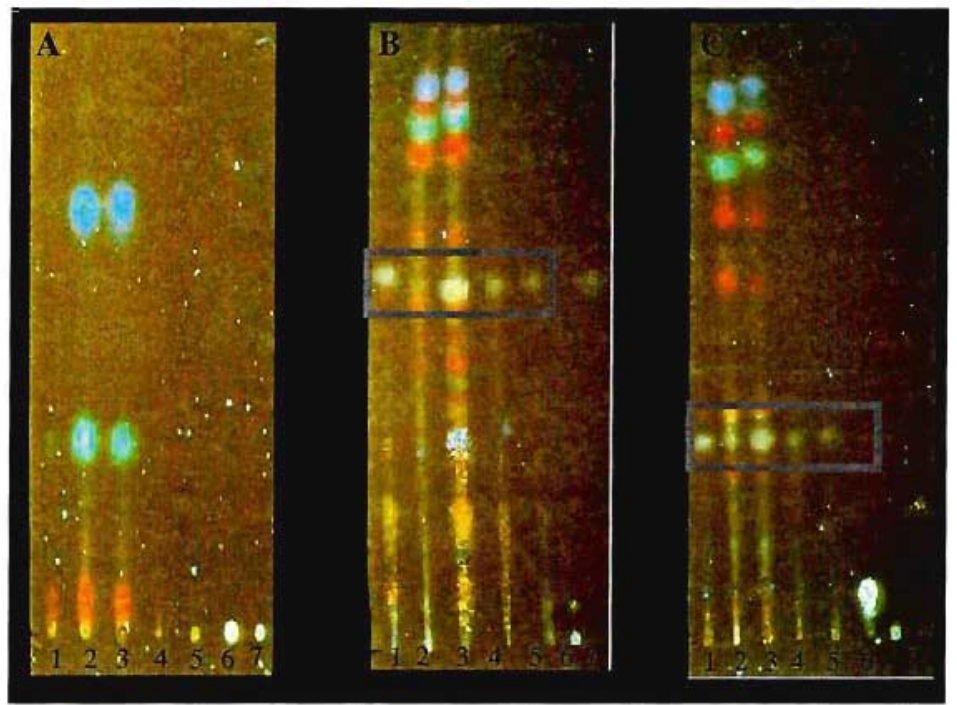

Figura 13: Perfil Cromatográfico do extrato bruto liofilizado (1) e das frações (clorofórmica (2); acetato de etila (3); etanólica 100\% (4) e etanólica $50 \%(5)$ ) de caule de Caesalpinia ferrea. A) Sistema: Hexano:Acetato de Etila (9:1). O ácido cafeico (6) e o ácido clorogênico (7) foram utilizados como padrões. B) Sistema: Clorofórmio: Acetato de Etila: Acetona (75:8,5:16,5). O ácido clorogênico (6) e a naringenina (7) foram utilizados como padrões. C) Sistema: Clorofórmio: Acetato de Etila: Etanol (98:2:3). O ácido cafeico (6) e o ácido clorogênico (7) foram utilizados como padrões. Composto químico presente no extrato bruto liofilizado de caule e em todas as suas frações (em destaque dentro do retângulo). 


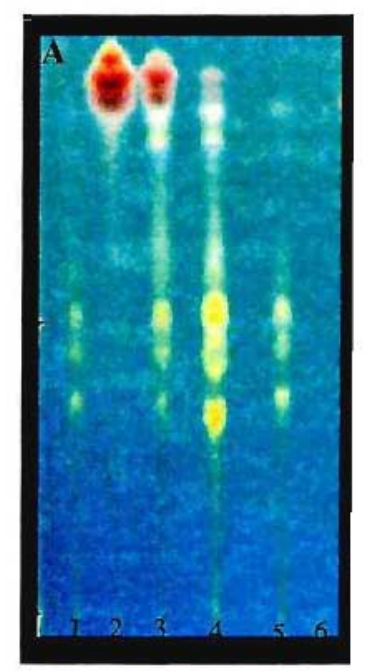

Figura 14: Perfil Cromatográfico do extrato bruto liofilizado (1) e das frações (clorofórmica (2); acetato de etila (3); etanólica 100\% (4) e etanólica 50\% (5)) de folha de Caesalpinia ferrea. Sistema: I-Acetato de Etila: Ácido Fórmico: Butanona: Água (75:10:5:10) II: Acetato de Etila: Ácido Acético (95:5). O ácido gálico (6) foi utilizado como padrão.

\section{5. $\mathrm{DL}_{50}$}

Tabela 5: $\mathrm{DL}_{50}$ do Extrato Bruto Liofilizado de Folha (EBLF) de C. ferrea, administrado por via oral nas doses de 1538, 2461, 3938, 6300 e $10.080 \mathrm{mg} / \mathrm{kg}$ para camundongos Swiss fêmeas e machos.

\begin{tabular}{ccc}
\hline & \multicolumn{2}{c}{ EBLF } \\
\hline & \multicolumn{2}{c}{$N^{0}$ de Mortes } \\
\hline Dose $(\mathrm{mg} / \mathrm{kg})$ & Fêmeas & Machos \\
\hline 1538 & 0 & 0 \\
2461 & 1 & 3 \\
3938 & 0 & 2 \\
6300 & 3 & 5 \\
10.080 & 5 & $--\cdot-\cdot--$ \\
\hline DL $_{50}(\mathbf{m g} / \mathbf{k g})$ & $\mathbf{5 4 7 1 . 6 4}$ & $\mathbf{3 1 1 2 . 9 4}$ \\
\hline
\end{tabular}


A partir da dose de $2.461 \mathrm{mg} / \mathrm{kg}$, após 120 minutos da administração do extrato bruto liofilizado de folha (EBLF), já podia se observar alteração comportamental como respiração ofegante.

Os animais, fêmeas e machos, que receberam EBLF nas doses de $3.938 \mathrm{mg} / \mathrm{kg}$ e $6.300 \mathrm{mg} / \mathrm{kg}$, apresentaram hemorragia pelo nariz., além de respiraçăo ofegante e emissão de sons. Algumas fêmeas ainda apresentaram ptose palpebrar e piloereçāo. Os que morreram, exibiram pulmão, fígado e pâncreas com coloração alterada (pontos escuros) e porção do intestino delgado e estômago com sangue internamente. Já todos os camundongos que receberam $10.080 \mathrm{mg} / \mathrm{kg}$ de EBLF morreram em menos de 24 horas após a administração do mesmo. Estes animais apresentaram respiração ofegante, emissão de sons, ptose palpebrar, pulmão de coloração alterada (hiperemia), hemorragia na região do pulmão/coração e fígado com pontos escuros, mas não tiveram hemorragia no trato gastrintestinal.

Todas as mortes ocorreram até 96 horas após a administração do extrato. 


\subsection{TOXICIDADE AGUDA}

Os resultados da Toxicidade Aguda encontram-se nas Figuras 15-17.

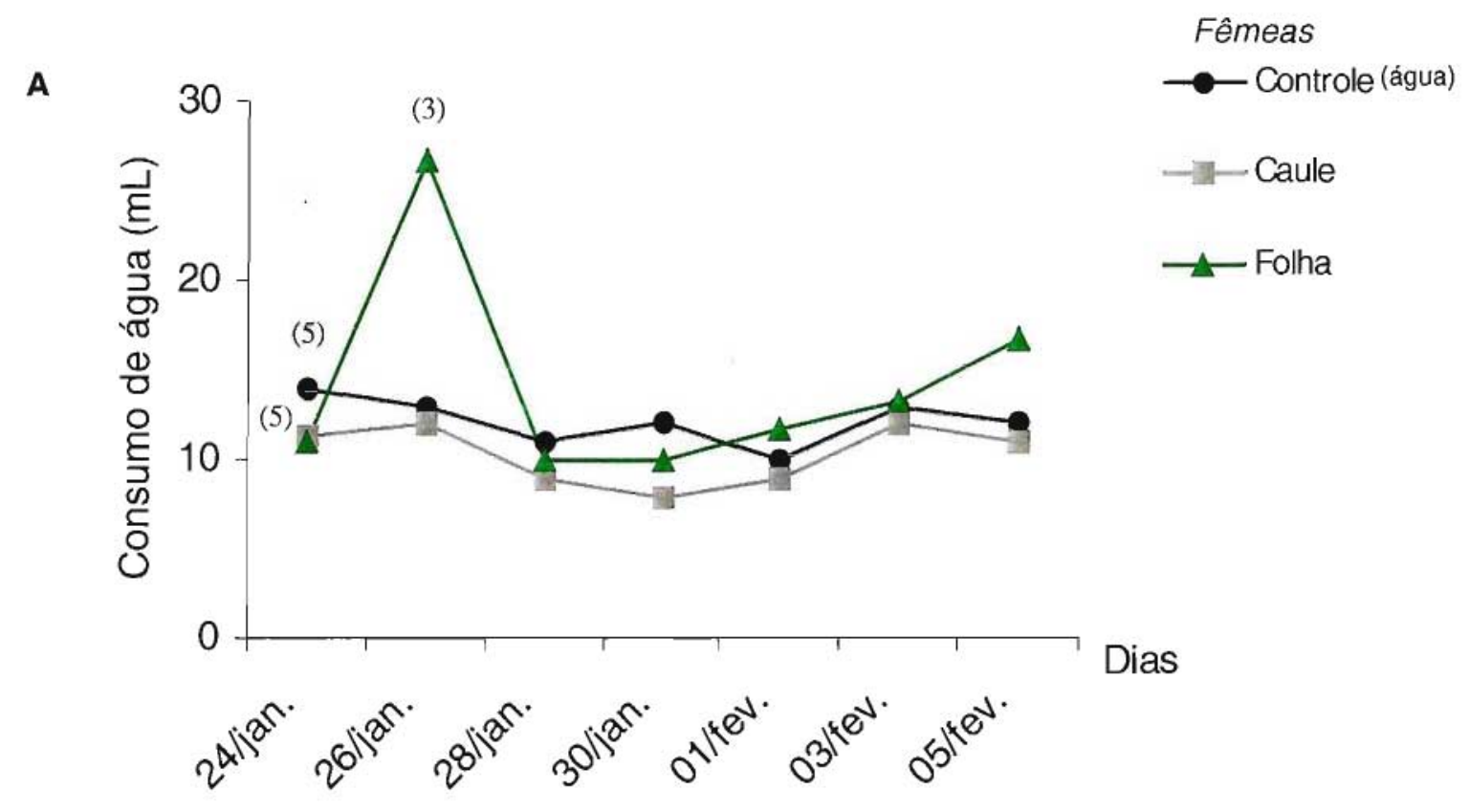

B

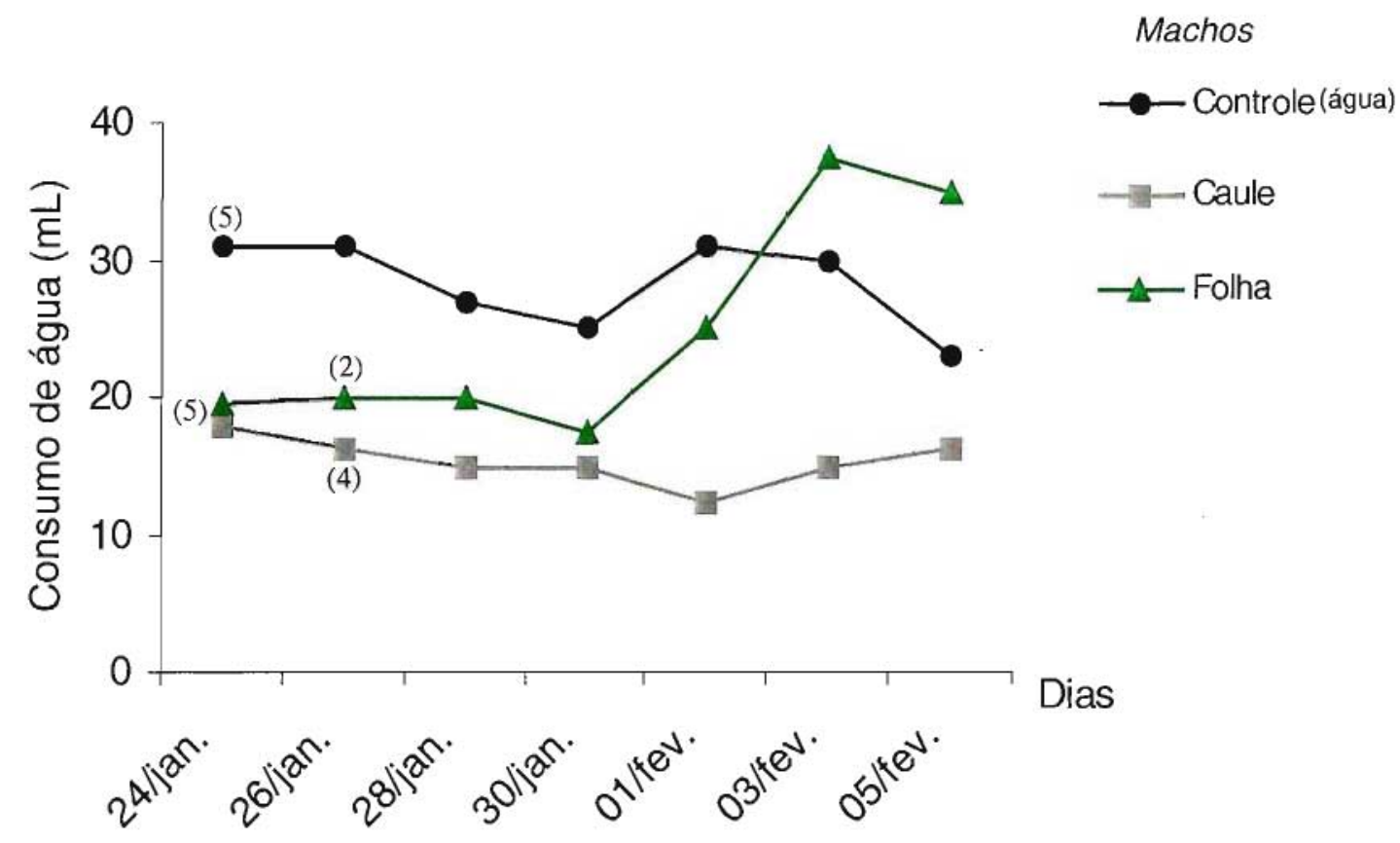

Figura 15: Variação do consumo de água $(\mathrm{mL})$ dos animais fêmeas (A) e machos (B) dos grupos Controle e Tratados (Extratos brutos liofilizados de folhas e caule de C.ferrea), avaliado a cada 2 dias, durante 14 dias, no teste de toxicidade aguda dose única, $5 \mathrm{~g} / \mathrm{kg}$, v.o. Cada ponto corresponde à média de consumo por grupo, sendo que entre parênteses está representado o número de animais em cada grupo experimental ao decorrer do ensaio toxicológico. 
A

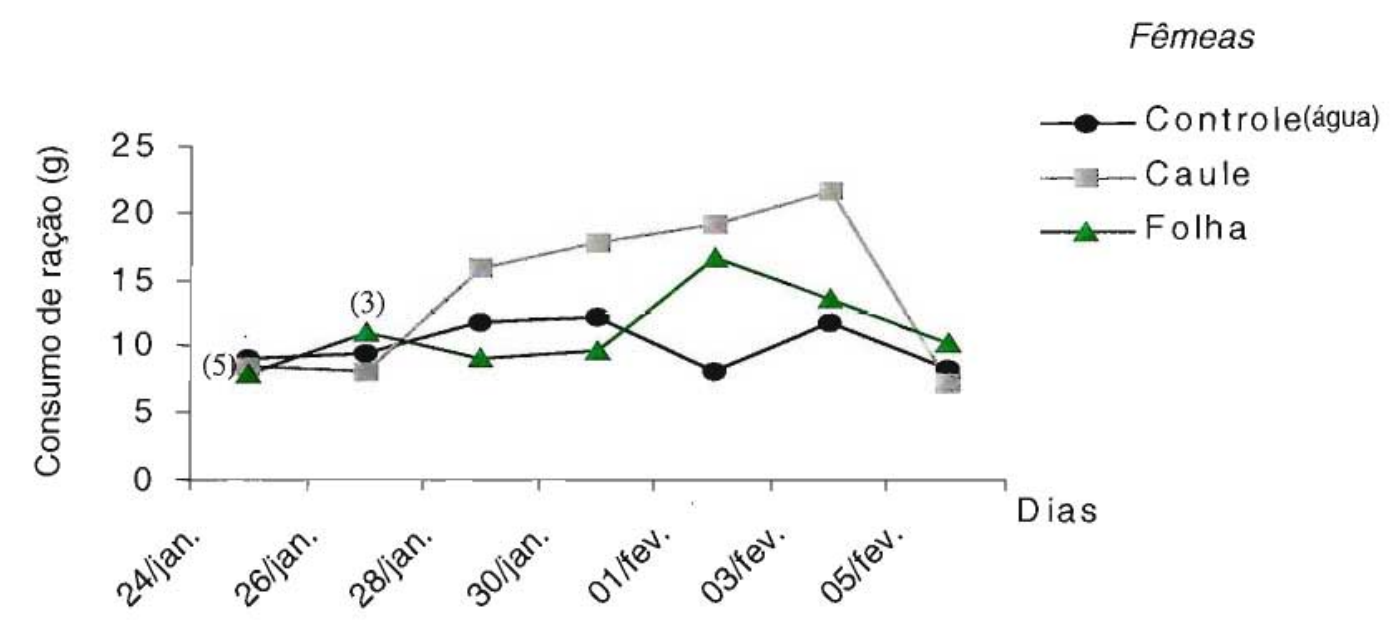

B

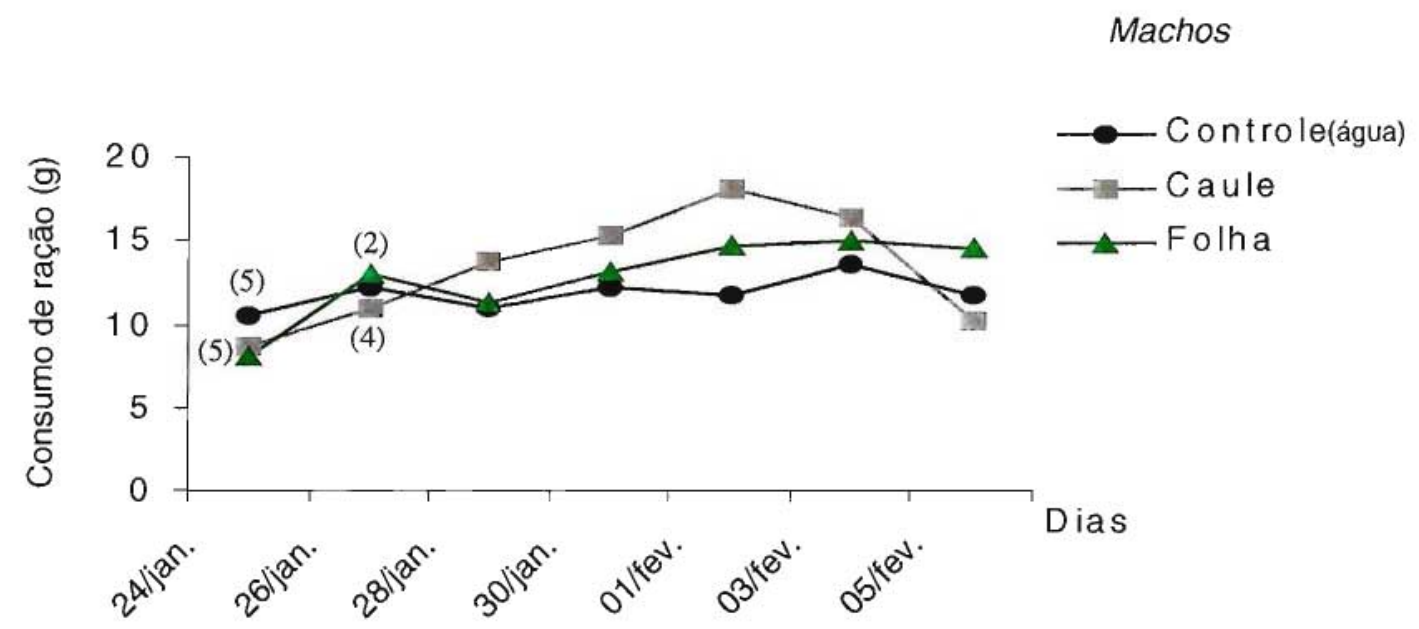

Figura 16: Variação do consumo de ração (g) dos animais fêmeas (A) e machos (B) dos grupos Controle e Tratados (Extratos brutos liofilizados de folhas e caule de C.ferrea), avaliado a cada 2 dias, durante 14 dias, no teste de toxicidade aguda dose única, $5 \mathrm{~g} / \mathrm{kg}$, v.o. Cada ponto corresponde à média de consumo por grupo, sendo que entre parênteses está representado o número de animais em cada grupo experimental ao decorrer do ensaio toxicológico. 
A

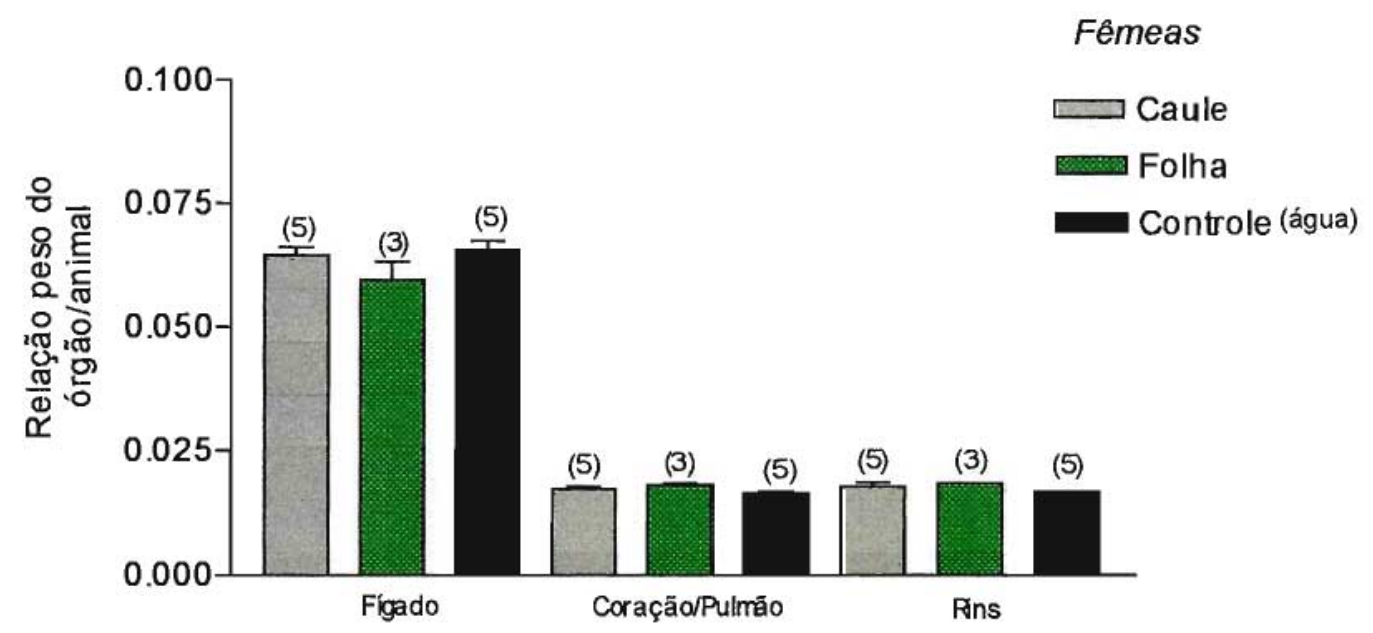

B

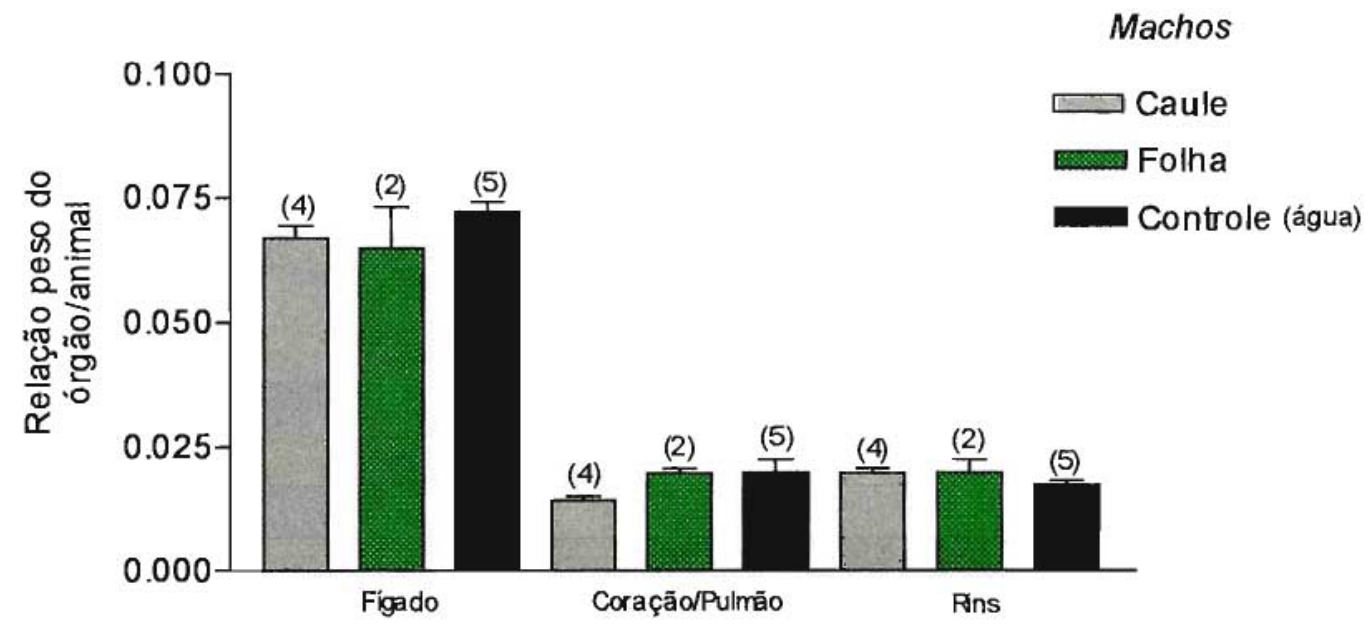

Figura 17: Comparação entre as massas relativas de órgãos dos animais fêmeas (A) e machos (B) dos grupos Controle e Tratados (Extratos brutos liofilizados de folhas e caule de $C$. ferrea), no teste de toxicidade aguda dose única, $5 \mathrm{~g} / \mathrm{kg}$, v.o. Cada ponto corresponde à média da massa relativa de peso do órgão por animal e seus respectivos erros padrões, sendo que entre parênteses está representado o número de animais em cada grupo experimental ao final do ensaio toxicológico. 
No ensaio biológico de toxicidade aguda de dose única, $5000 \mathrm{mg} / \mathrm{kg}$, v.o., foram observados em alguns dos animais machos e fêmeas que receberam o EBLF de $C$. ferrea, escurecimento da mucosa na porção final do intestino, bem como sangue e fezes de consistência alterada (líquida) no seu interior.

Além destes efeitos, os animais machos apresentaram respiração ofegante, hiperexcitabilidade, aumento na reação de susto, redução do reflexo de endireitamento até parada cárdio-respiratória, e as fêmeas manifestaram apenas alteração na freqüência respiratória, ocorrendo a morte de 3 animais machos e 2 fêmeas. Estes animais foram necropsiados e as alterações morfológicas registradas foram pulmão, fígado e rins de coloração alterada com pontos escuros nos 3 animais machos e numa das fêmeas, em outra, apenas 0 pulmão apresentou modificação de cor.

Já, os animais que receberam o EBLC de C. ferrea, dose única, 5000 $\mathrm{mg} / \mathrm{kg}$, v.o., na toxicidade aguda, não apresentaram nenhuma alteração comportamental, exceto um animal macho que exibiu uma diminuição na atividade motora, bem como respiração ofegante até parada cárdio-respiratória, 96 horas após a administração do extrato. Este animal foi autopsiado e as alterações morfológicas registradas foram semelhantes às já citadas anteriormente. 


\subsection{TOXICIDADE SUBCRÔNICA}

Os resultados da Toxicidade subcrônica encontram-se nas Figuras 1821.

A

Fêmeas

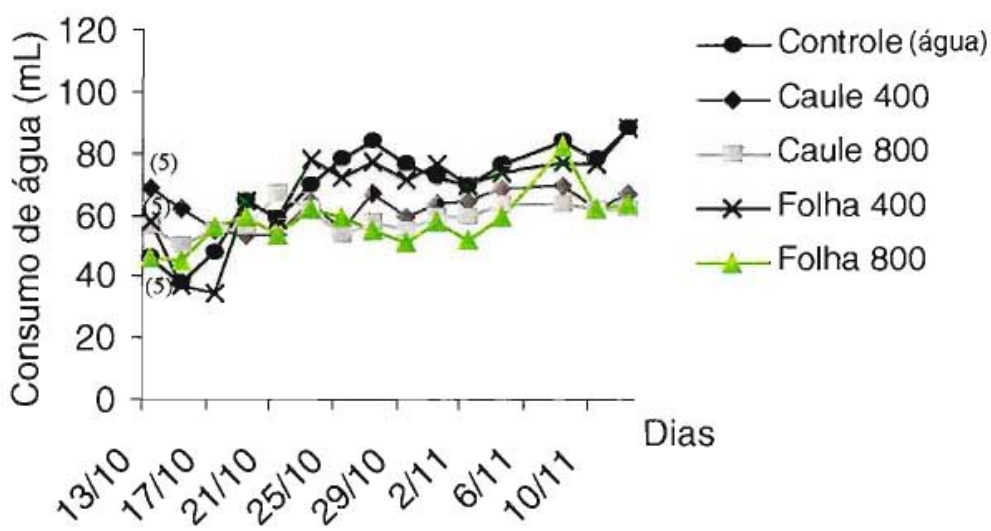

B

Machos

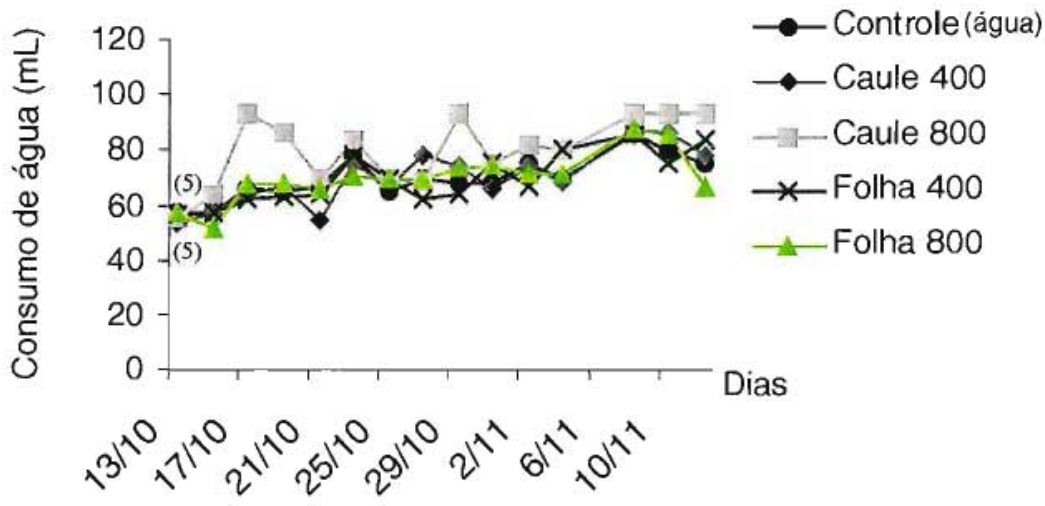

Figura 18: Variação do consumo de água $(\mathrm{mL})$ dos animais fêmeas (A) e machos (B) dos grupos Controle e Tratados (Extratos brutos liofilizados de caule e folha de Caesalpinia ferrea), avaliado a cada 2 dias, durante 33 dias, no teste de toxicidade subcrônica, nas doses diárias, $400 \mathrm{mg} / \mathrm{kg}$ e $800 \mathrm{mg} / \mathrm{kg}$, v.o. Cada ponto corresponde à média de consumo por grupo, sendo que entre parênteses está representado o número de animais em cada grupo experimental ao decorrer do ensaio toxicológico. 


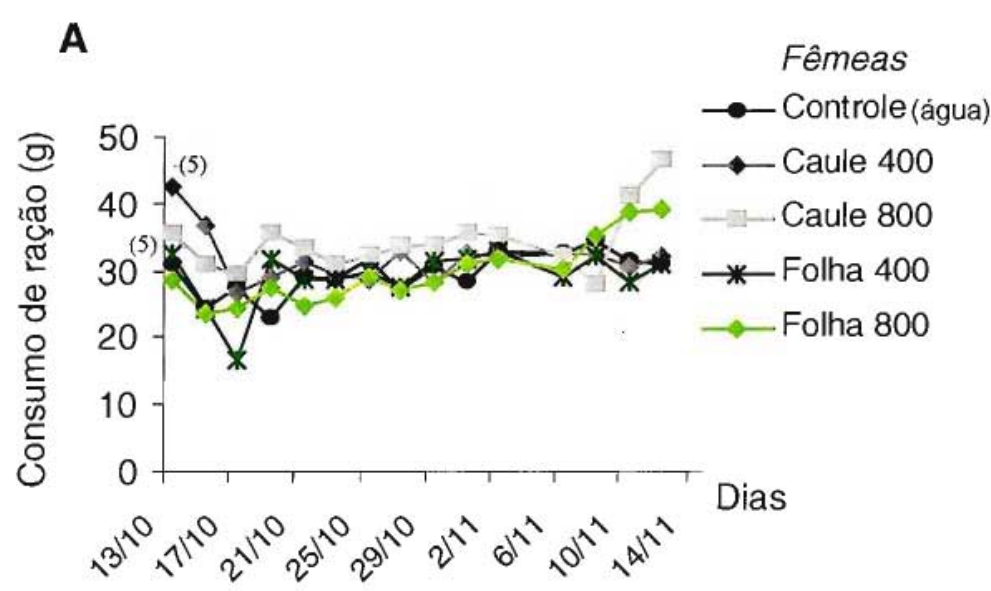

B

Machos

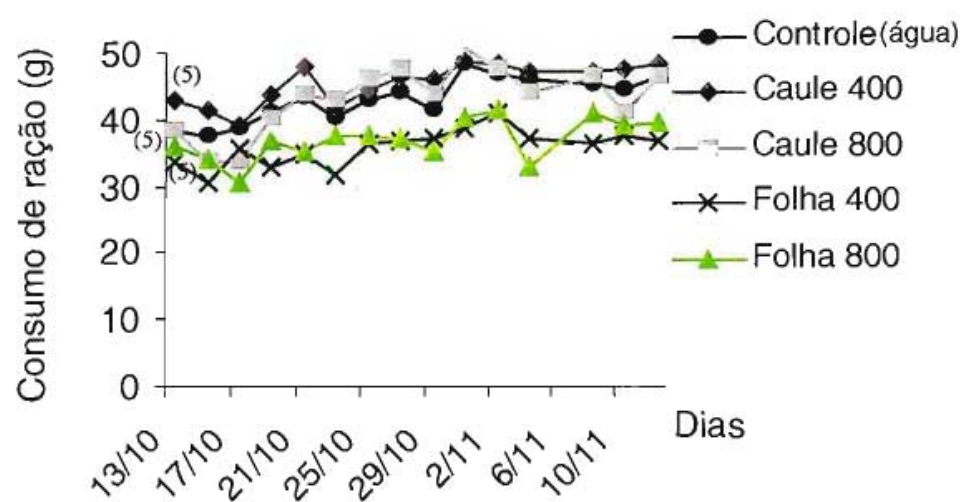

Figura 19: Variação do consumo de ração (g) dos animais fêmeas (A) e machos (B) dos grupos Controle e Tratados (Extratos brutos liofilizados de caule e folha de Caesalpinia ferrea), avaliado a cada 2 dias, durante 33 dias, no teste de toxicidade subcrônica, nas doses diárias, $400 \mathrm{mg} / \mathrm{kg}$ e $800 \mathrm{mg} / \mathrm{kg}$, v.o. Cada ponto corresponde à média de consumo por grupo, sendo que entre parênteses está representado o número de animais em cada grupo experimental ao decorrer do ensaio toxicológico. 
(A)

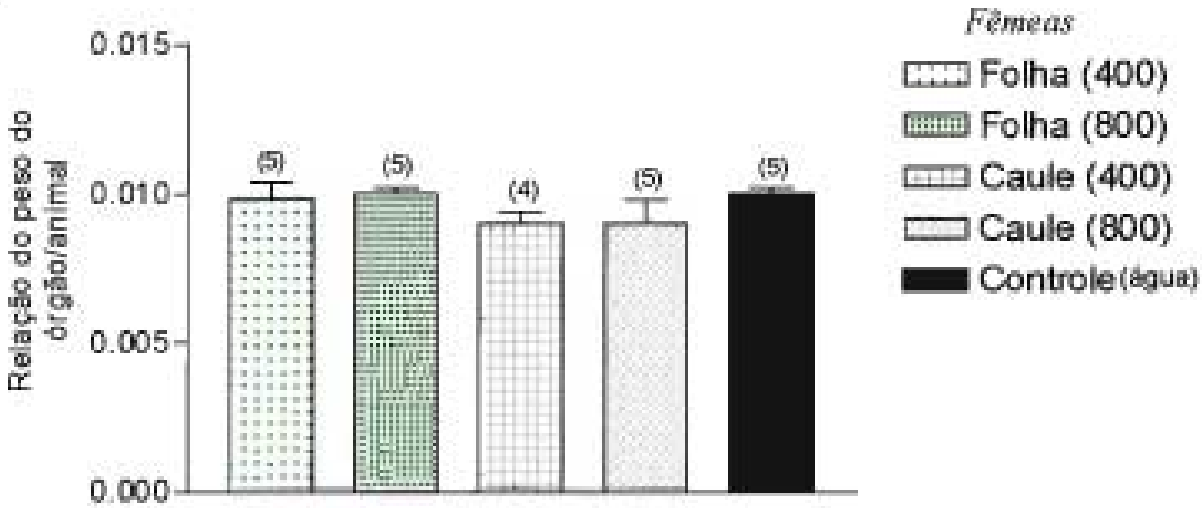

(B)

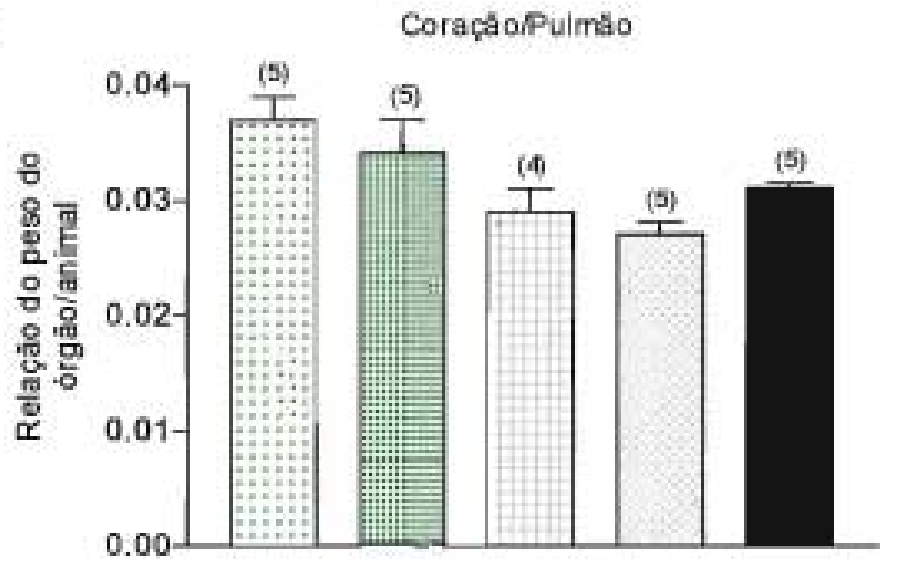

(C)

Figado

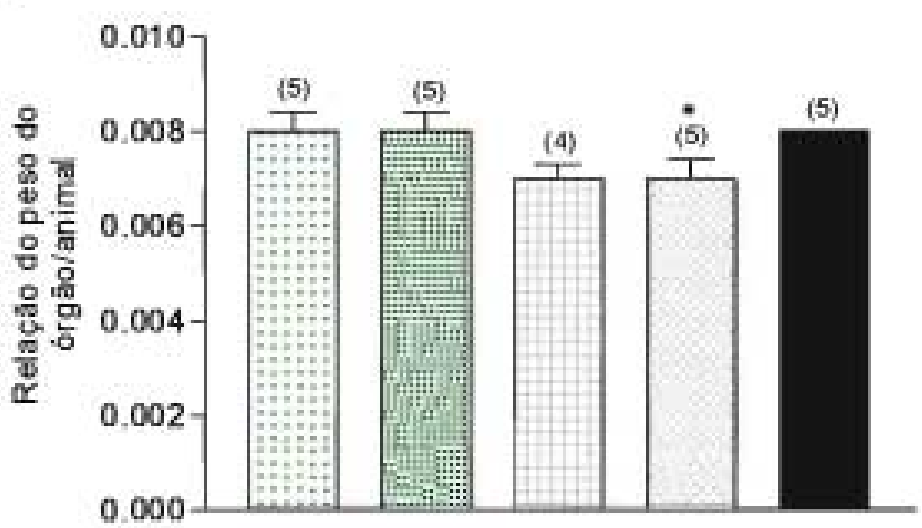

Rins

Figura 20: Comparação entre as massas relativas de órgăos dos animais fermeas dos grupos Controle e Tratados (Extratos brutos liofilizados de caule e folha de C. ferrea), no teste de toxicidade subcrônica, nas doses de $400 \mathrm{mg} / \mathrm{kg}$ e $800 \mathrm{mg} / \mathrm{kg}$, v.o. Cada ponto corresponde à média da massa relativa de coração/pulmäo (A), figado (B) e rins (C) por grupo e seus respectivos erros padrăo ( ${ }^{\star} p<0.05$; Teste de Tukey); entre parênteses está representado o número de animais em cada grupo experimental ao final do ensaio toxicológico. 
(A)

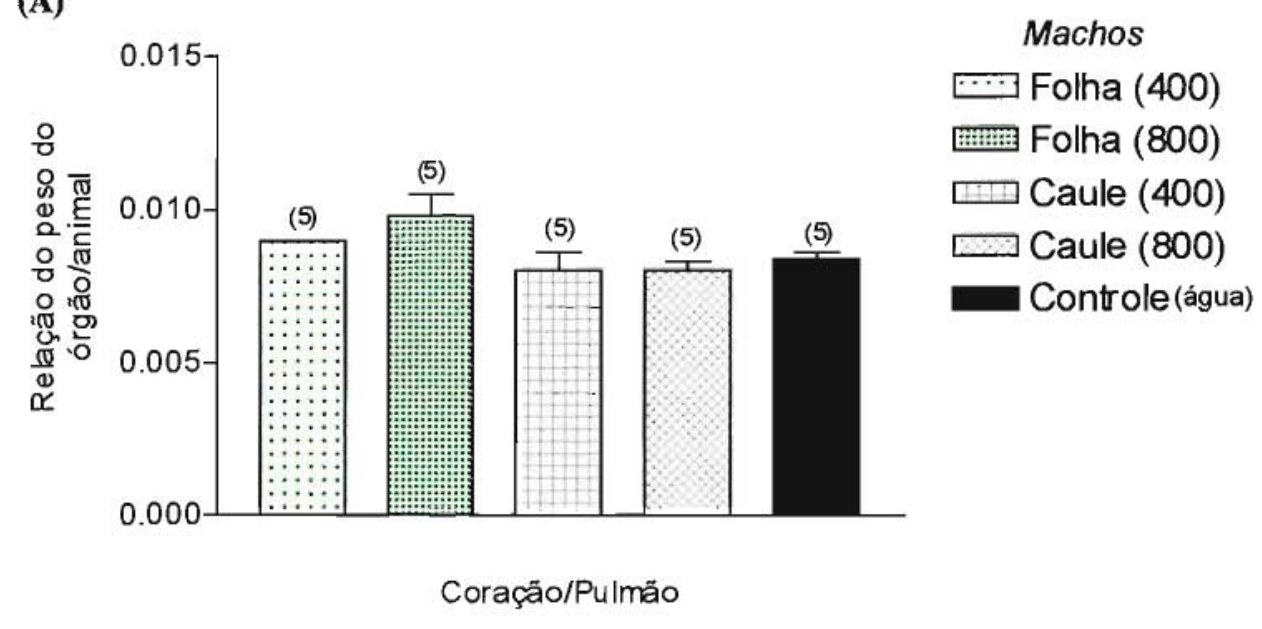

(B)

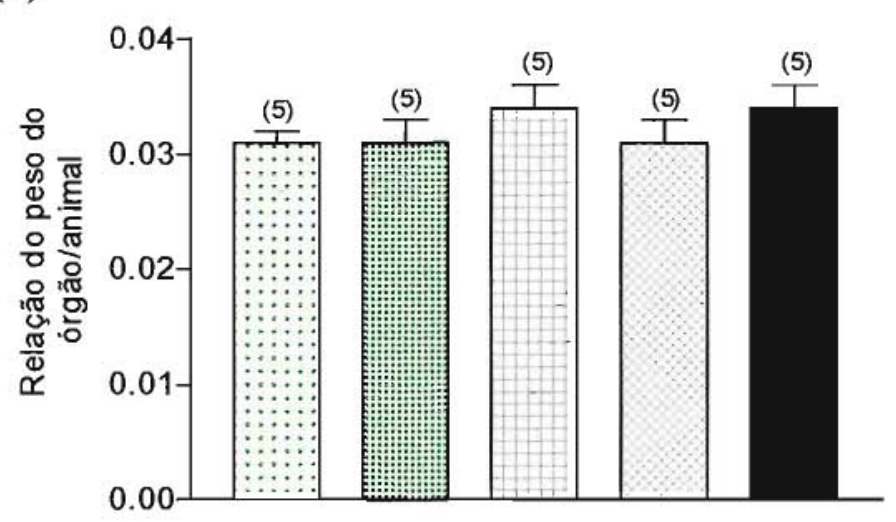

Figado

(C)

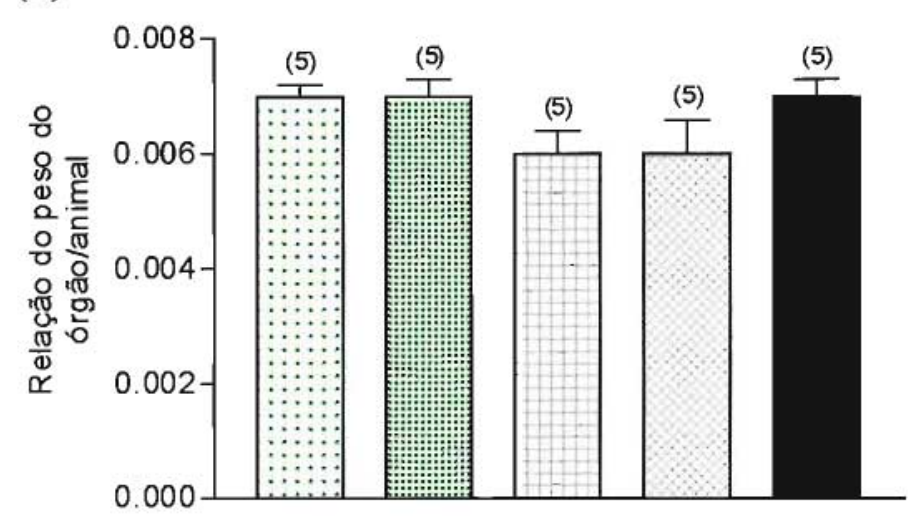

Rins

Figura 21: Comparação entre as massas relativas de órgãos dos animais machos dos grupos Controle e Tratados (Extratos brutos liofilizados de caule e folha de $C$. ferrea), no teste de toxicidade subcrônica, nas doses de $400 \mathrm{mg} / \mathrm{kg}$ e $800 \mathrm{mg} / \mathrm{kg}$, v.o. Cada ponto corresponde à média da massa relativa de coração/pulmão (A), fígado (B) e rins (C) por grupo e seus respectivos erros padrão; entre parênteses está representado o número de animais em cada grupo experimental ao final do ensaio toxicológico. 
Quanto aos resultados da análise histológica dos órgãos retirados ao término da toxicidade subcrônica (coração/pulmão, fígado e rim) não evidenciaram-se alterações histopatológicas dignas de nota. 
Tabela 6: Determinação dos parâmetros Hematológicos dos animais fêmeas e machos submetidos à Avaliação da Toxicidade Subcrônica dos extratos brutos liofilizados de folha e caule de Caesalpinia ferrea, nas doses de 400 e $800 \mathrm{mg} / \mathrm{kg}$, v.o., durante 33 dias.

\begin{tabular}{|c|c|c|c|c|}
\hline Fêmeas & $\mathrm{Hb}(\mathrm{g} / \mathrm{dL})$ & $\mathrm{Ht}(\%)$ & $\operatorname{Hem}\left(x 10^{6}\right)$ & Leuc $\left(/ \mathrm{mm}^{3}\right)$ \\
\hline \multicolumn{5}{|c|}{ CONTROLE } \\
\hline 1 & 10,88 & 38 & 5,40 & 6100 \\
\hline 2 & 11,10 & 39 & 5,66 & 6550 \\
\hline
\end{tabular}

FOLHA

\begin{tabular}{lllll}
\hline $400 \mathrm{mg} / \mathrm{kg}$ & & & & \\
1 & 11,73 & 36 & 5,4 & 5050 \\
2 & 10,28 & 36 & 5,4 & 5850 \\
\hline $800 \mathrm{mg} / \mathrm{kg}$ & & & & \\
1 & 12,02 & 38 & 5,4 & 7550 \\
2 & 12,89 & 37 & 5,2 & 7600 \\
\hline
\end{tabular}

\begin{tabular}{lllll}
\hline $400 \mathrm{mg} / \mathrm{kg}$ & & & & \\
1 & 14,90 & 35 & 5,12 & 6200 \\
2 & 13,04 & 33 & 5,47 & 6600 \\
\hline $800 \mathrm{mg} / \mathrm{kg}$ & & & & \\
1 & 12,54 & 34 & 5,81 & 6900 \\
2 & 11,73 & 34 & 5,92 & 5400 \\
\hline
\end{tabular}

Legenda: Hb: Hemoglobina; Ht: Hematócito; Hem: Hemácia. 
Tabela 6: Determinação dos parâmetros Hematológicos dos animais fêmeas e machos submetidos à Avaliação da Toxicidade Subcrônica dos extratos brutos liofilizados de folha e caule de Caesalpinia ferrea, nas doses de 400 e $800 \mathrm{mg} / \mathrm{kg}$, v.o., durante 33 dias.

Forma Leucocitária Relativa (\%)

\begin{tabular}{|c|c|c|c|}
\hline Fêmeas & Linfócito & Monócito & Segmentado \\
\hline \multicolumn{4}{|c|}{ CONTROLE } \\
\hline 1 & 88 & 3 & 9 \\
\hline 2 & 86 & 5 & 9 \\
\hline
\end{tabular}

FOLHA

\begin{tabular}{llll}
\hline $400 \mathrm{mg} / \mathrm{kg}$ & & & \\
1 & 86 & 2 & 12 \\
2 & 89 & 2 & 9 \\
\hline $800 \mathrm{mg} / \mathrm{kg}$ & & & \\
1 & 88 & 2 & 10 \\
2 & 85 & 2 & 13 \\
\hline
\end{tabular}

OALLE

\begin{tabular}{llll}
\hline $400 \mathrm{mg} / \mathrm{kg}$ & 85 & 1 & 14 \\
1 & 89 & 1 & 10 \\
\hline 2 & & & \\
1 & $800 \mathrm{mg} / \mathrm{kg}$ & 2 & 10 \\
2 & 83 & 3 & 14 \\
\hline
\end{tabular}


Tabela 6: Determinação dos parâmetros Hematológicos dos animais fêmeas e machos submetidos à Avaliação da Toxicidade Subcrônica dos extratos brutos liofilizados de folha e caule de Caesalpinia ferrea, nas doses de 400 e $800 \mathrm{mg} / \mathrm{kg}$, v.o., durante 33 dias.

\section{Forma Leucocitária Absoluta $\left(/ \mathrm{mm}^{3}\right)$}

\begin{tabular}{lrccc}
\hline Fêmeas & Linfócito & Monócito & Segmentado & Eosinófilo \\
\hline \multirow{2}{*}{ CONTROLE } & & & & \\
1 & 5338 & 183 & 549 & 0 \\
2 & 5633 & 327 & 589 & 0 \\
\hline
\end{tabular}

FOLHA

\begin{tabular}{lllll}
\hline $4400 \mathrm{mg} / \mathrm{kg}$ & & & & \\
1 & 4343 & 101 & 606 & 0 \\
2 & 5206 & 117 & 526 & 0 \\
\hline $\mathbf{7} 800 \mathrm{mg} / \mathrm{kg}$ & & & & 0 \\
2 & 6644 & 151 & 755 & 0 \\
\hline
\end{tabular}

\begin{tabular}{lllll}
\hline $400 \mathrm{mg} / \mathrm{kg}$ & & & & \\
1 & 5270 & 62 & 868 & 0 \\
2 & 5874 & 66 & 660 & 0 \\
\hline \multirow{2}{*}{$800 \mathrm{mg} / \mathrm{kg}$} & & & & \\
1 & 6072 & 138 & 690 & 0 \\
2 & 4482 & 162 & 756 & 0 \\
\hline
\end{tabular}


Tabela 6: Determinação dos parâmetros Hematológicos dos animais fêmeas e machos submetidos à Avaliação da Toxicidade Subcrônica dos extratos brutos liofilizados de folha e caule de Caesalpinia ferrea, nas doses de 400 e $800 \mathrm{mg} / \mathrm{kg}$, v.o., durante 33 dias.

\begin{tabular}{lcccc}
\hline Machos & $\mathrm{Hb}(\mathbf{g} / \mathrm{dL})$ & $\mathrm{Ht}(\%)$ & Hem $\left(\mathbf{\times 1 0 ^ { 6 } )}\right.$ & Leuc $\left(/ \mathrm{mm}^{3}\right)$ \\
\hline \multirow{2}{*}{ CONTROLE } & & & & \\
1 & 12,82 & 42 & 5,94 & 7400 \\
2 & 13,10 & 40 & 5,85 & 9600 \\
\hline
\end{tabular}

FOLHA

\begin{tabular}{|c|c|c|c|c|}
\hline \multicolumn{5}{|c|}{$400 \mathrm{mg} / \mathrm{kg}$} \\
\hline 1 & 12,1 & 44 & 6,20 & 5800 \\
\hline 2 & 11,10 & 42 & 6,11 & 6300 \\
\hline & & & & \\
\hline 1 & 13,10 & 42 & 6,3 & 7400 \\
\hline 2 & 13,70 & 45 & 6,6 & 9100 \\
\hline
\end{tabular}

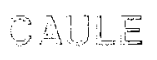

\begin{tabular}{|c|c|c|c|c|}
\hline \multicolumn{5}{|c|}{ - $400 \mathrm{ma} / \mathrm{kg}$} \\
\hline 1 & 13,68 & 38 & 5,32 & 8800 \\
\hline 2 & 12,54 & 37 & 5,41 & 7850 \\
\hline \multicolumn{5}{|c|}{ * $800 \mathrm{mg} / \mathrm{kg}$} \\
\hline 1 & 14,71 & 39 & 6,02 & 10000 \\
\hline 2 & 12,84 & 36 & 6,05 & 8100 \\
\hline
\end{tabular}

Legenda: Hb: Hemoglobina; Ht: Hematócito; Hem: Hemácia. 
Tabela 6: Determinação dos parâmetros Hematológicos dos animais fêmeas e machos submetidos à Avaliação da Toxicidade Subcrônica dos extratos brutos liofilizados de folha e caule de Caesalpinia ferrea, nas doses de 400 e $800 \mathrm{mg} / \mathrm{kg}$, v.o., durante 33 dias.

\begin{tabular}{|c|c|c|c|}
\hline \multirow[b]{2}{*}{ Machos } & \multicolumn{3}{|c|}{ Forma Leucocitária Relativa (\%) } \\
\hline & Linfócito & Monócito & Segmentado \\
\hline \multicolumn{4}{|l|}{ CONTROLE } \\
\hline 1 & 88 & 3 & 9 \\
\hline 2 & 86 & 2 & 12 \\
\hline \multicolumn{4}{|l|}{ FOLHA } \\
\hline $400 \mathrm{mg} / \mathrm{kg}$ & & & \\
\hline 1 & 84 & 3 & 13 \\
\hline 2 & 89 & 2 & 9 \\
\hline \multicolumn{4}{|l|}{$800 \mathrm{mg} / \mathrm{kg}$} \\
\hline 1 & 79 & 4 & 17 \\
\hline 2 & 83 & 1 & 16 \\
\hline
\end{tabular}

\begin{tabular}{lrcc}
\hline $400 \mathrm{mg} / \mathrm{kg}$ & 90 & 1 & 9 \\
1 & 81 & 3 & 16 \\
\hline 2 & & & \\
1 & 78 & 3 & 18 \\
2 & 85 & 4 & 12 \\
\hline
\end{tabular}


Tabela 6: Determinação dos parâmetros Hematológicos dos animais fêmeas e machos submetidos à Avaliação da Toxicidade Subcrônica dos extratos brutos liofilizados de folha e caule de Caesalpinia ferrea, nas doses de 400 e $800 \mathrm{mg} / \mathrm{kg}$, v.o., durante 33 dias.

\section{Forma Leucocitária Absoluta $\left(/ \mathrm{mm}^{3}\right)$}

\begin{tabular}{lrccc} 
Machos & Linfócito & Monócito & Segmentado & Eosinófilo \\
\hline CONTROLE & & & & \\
1 & 6512 & 22 & 666 & 0 \\
2 & 8256 & 192 & 1152 & 0 \\
\hline
\end{tabular}

FOLHA

\begin{tabular}{lrrrl}
\hline $400 \mathrm{mg} / \mathrm{kg}$ & & & & \\
1 & 4872 & 174 & 754 & 0 \\
2 & 5607 & 126 & 567 & 0 \\
\hline $800 \mathrm{mg} / \mathrm{kg}$ & & & & \\
1 & 5846 & 296 & 1258 & 0 \\
2 & 7553 & 91 & 1456 & 0 \\
\hline
\end{tabular}

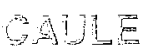

\begin{tabular}{lcccc}
\hline $400 \mathrm{mg} / \mathrm{kg}$ & & & & \\
1 & 7920 & 88 & 792 & 0 \\
2 & 6358 & 235 & 1256 & 0 \\
\hline $800 \mathrm{mg} / \mathrm{kg}$ & & & & \\
1 & 7800 & 400 & 1800 & 0 \\
2 & 6885 & 243 & 972 & 0 \\
\hline
\end{tabular}




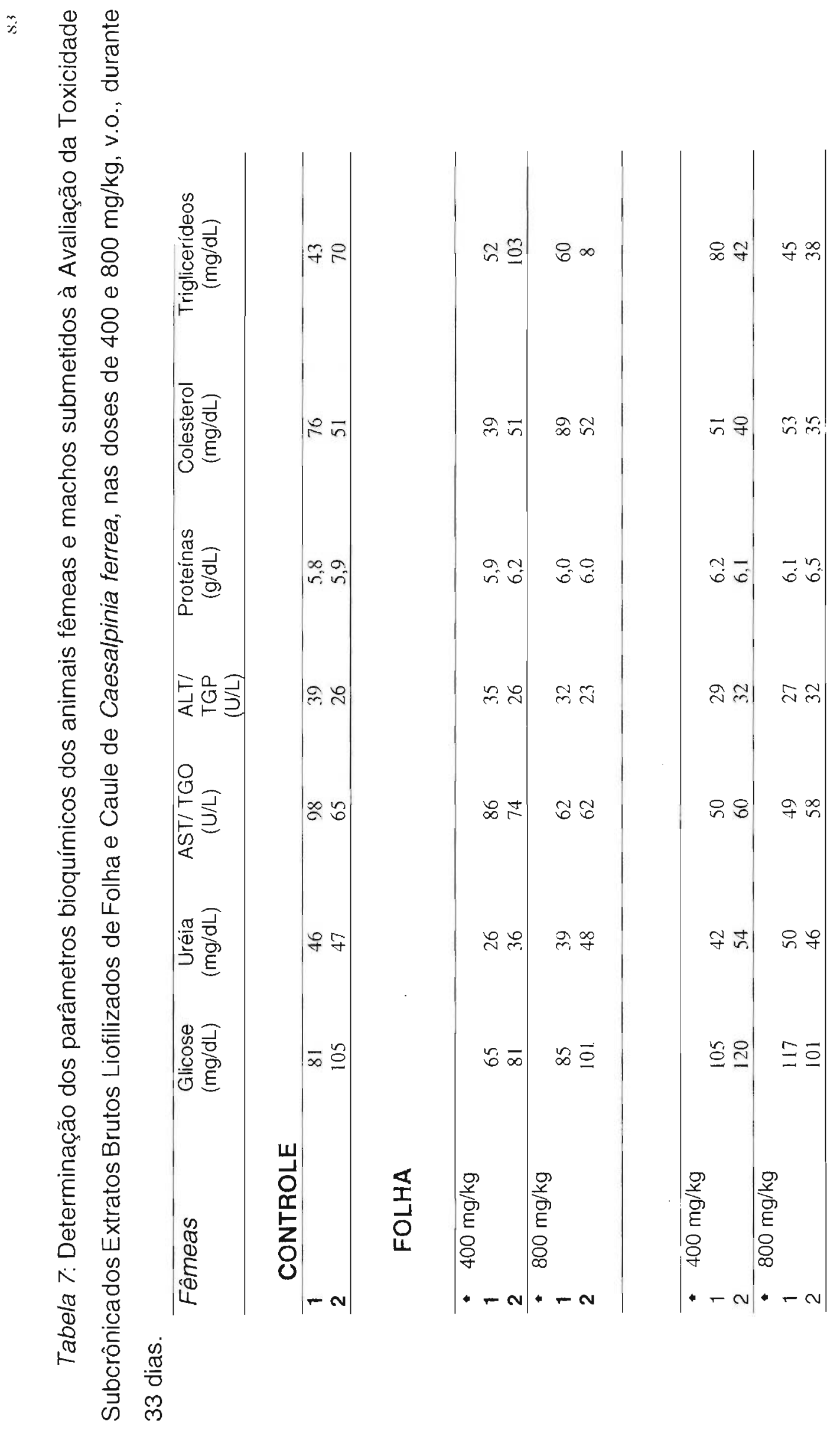




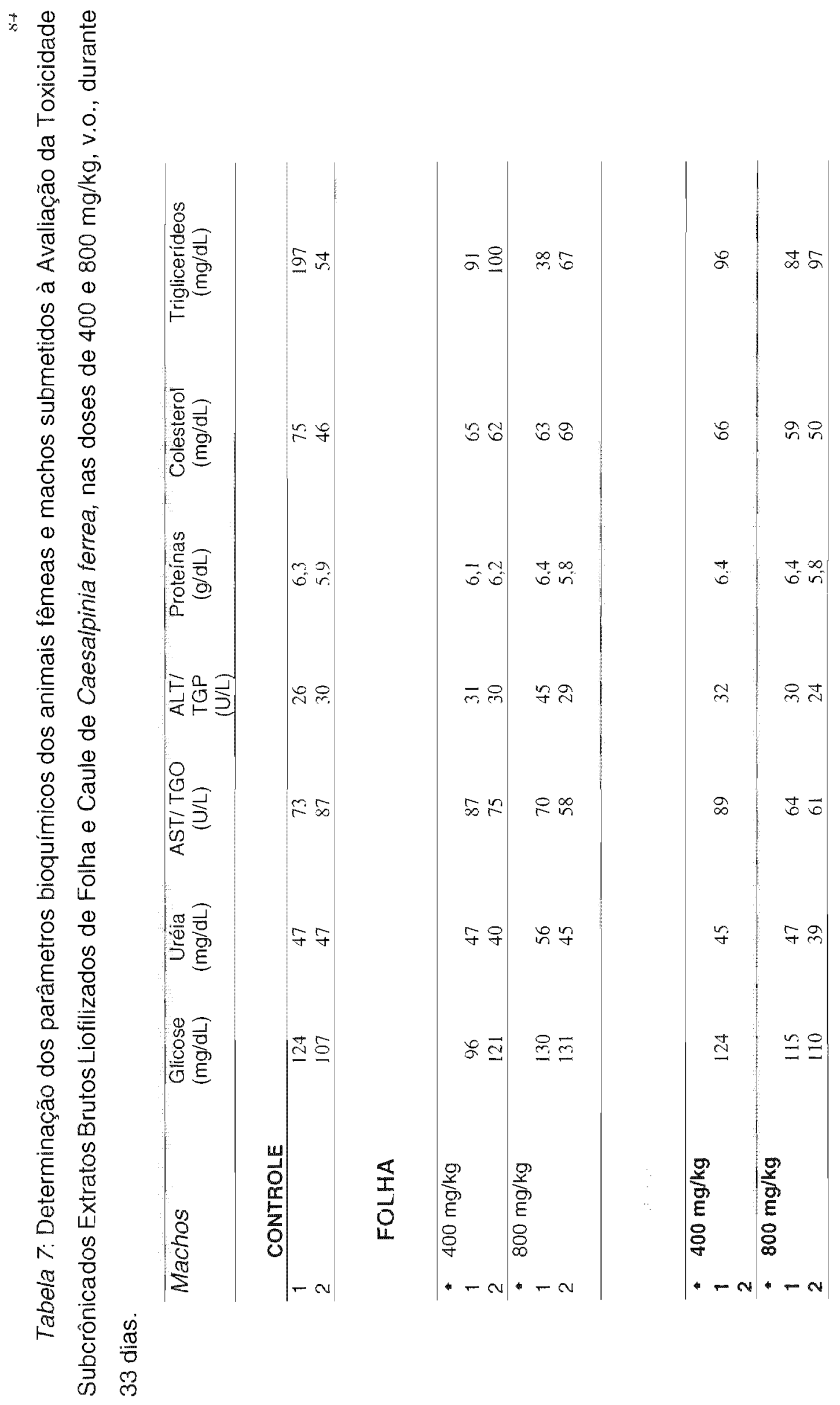




\subsection{ATIVIDADE ANTIÚLCERA AGUDA}

Indução de lesão gástrica pelo Etanol/HCl

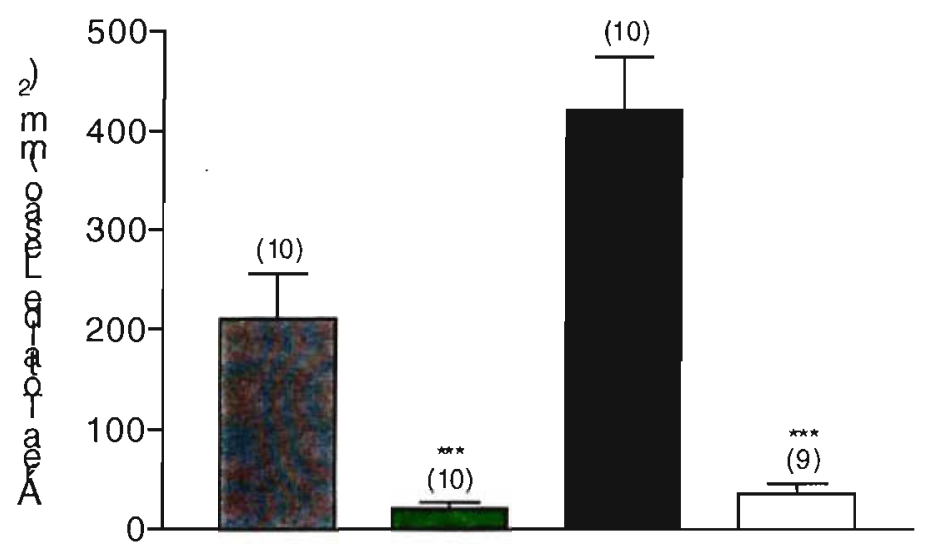

$\square$ Caule

Folha

Controle (água)

$\square$ Misoprostol
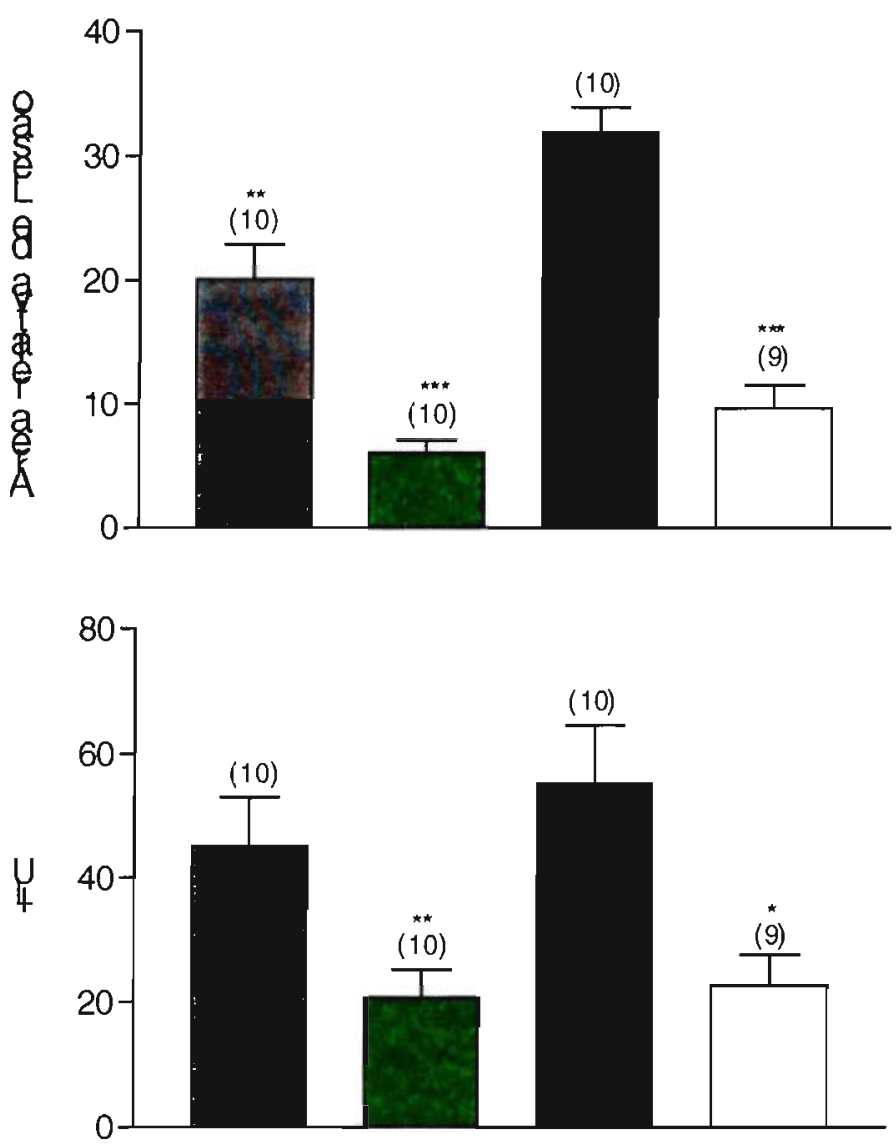

Figura 22: Efeito dos extratos hidroetanólicos $70 \%$ liofilizados de folhas e caule de C. ferrea, $400 \mathrm{mg} / \mathrm{kg}$ (v.o), no modelo de indução gástrica pelo Etanol $(60 \%) / \mathrm{HCl}(0.3 \mathrm{M}), 1 \mathrm{ml} / 100 \mathrm{~g}$ (v.o). No gráfico estão representadas as médias da Área Total de Lesão, da Área Relativa de Lesão e do ILU e seus respectivos erros padrões $\left({ }^{\star} p<0.05,{ }^{\star \star} p<0.01,{ }^{\star \star \star} p<0.001\right.$; ANOVA, Teste de Tukey ou Kruskal Wallis-Dunn). Entre parênteses está representado o número de animais utilizado em cada grupo experimental. 
Imagens dos estômagos do experimento de indução de lesões gástricas por etanol/HCl

C: Caule

F: Folha

CT: Controle

FR: Fármaco de referência (Misoprostol)
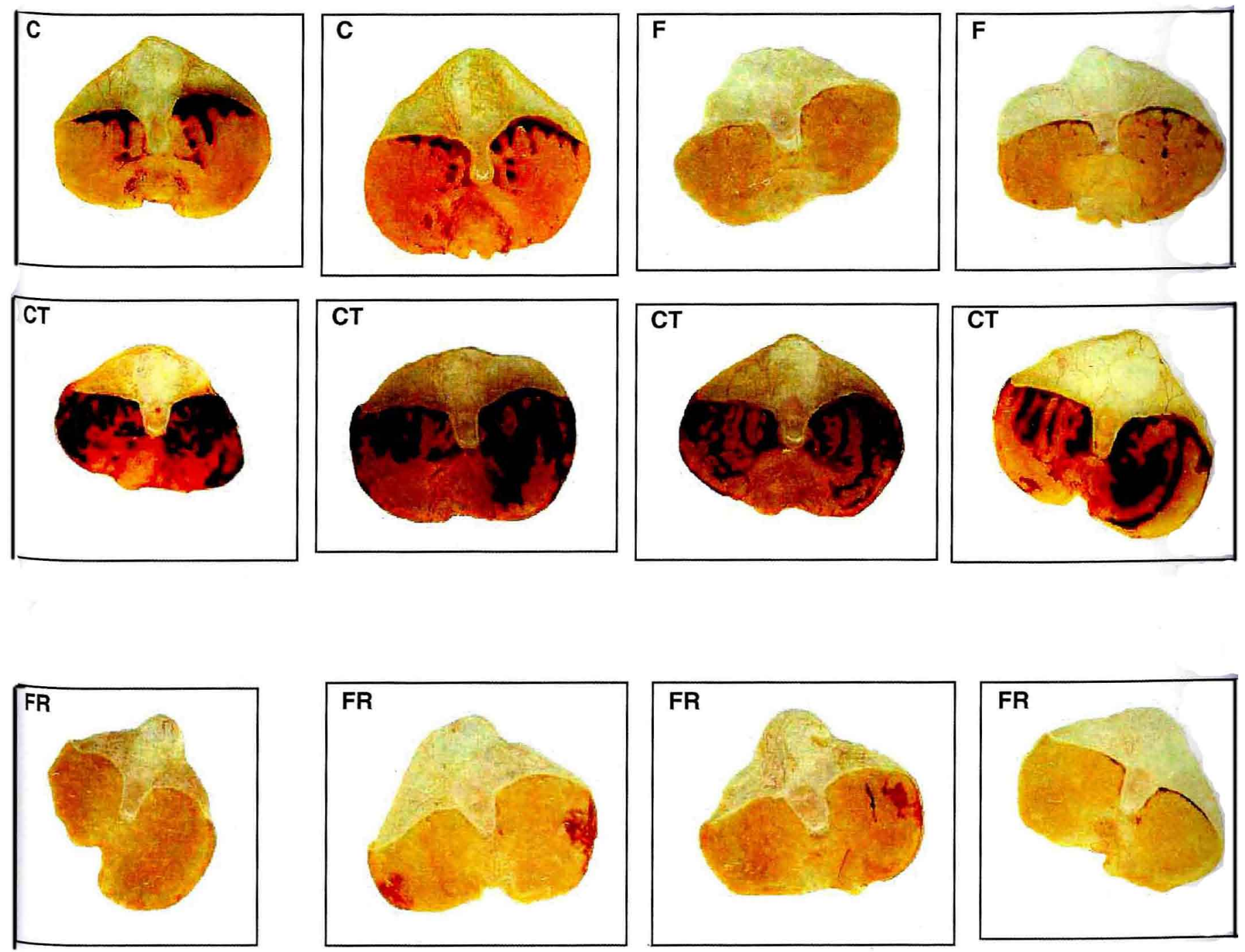


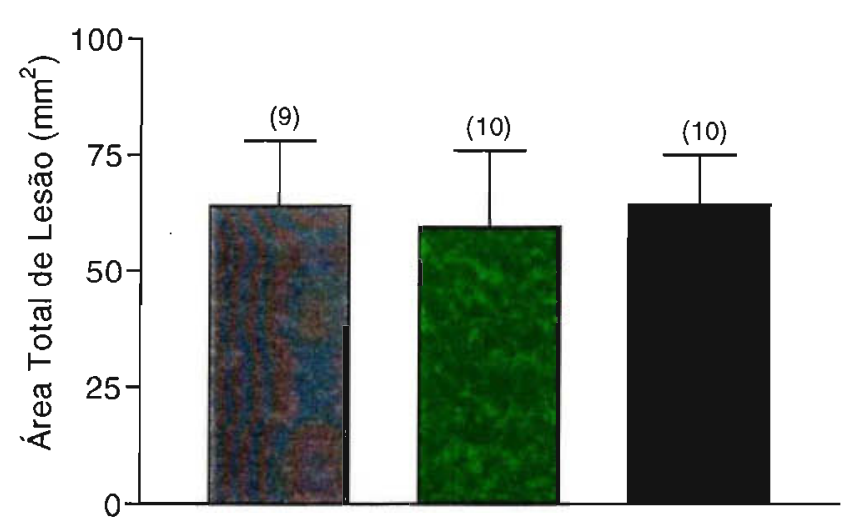

Frações enriquecidas em flavonóides
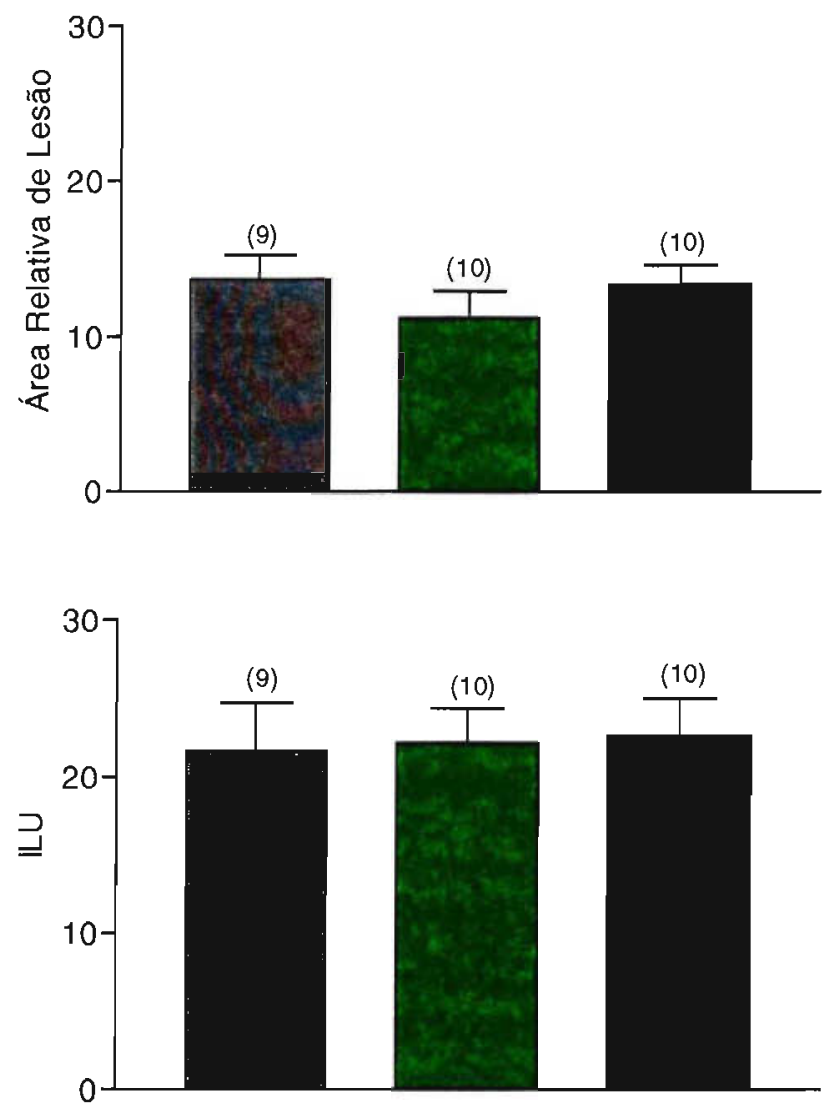

Figura 23: Efeito dos extratos de caule e folha de $C$. ferrea erriquecidos com flavonóides, $400 \mathrm{mg} / \mathrm{kg}$ (v.o), no modelo de indução gástrica pelo Etanol $(60 \%) / \mathrm{HCl}(0.3 \mathrm{M}), 1 \mathrm{ml} / 100 \mathrm{~g}$ (v.o). No gráfico estão representadas as médias da Área Total de Lesão, da Área Relativa de Lesão e do ILU e seus respectivos erros padrões (ANOVA, Teste de Tukey). Entre parênteses está representado o número de animais utilizado em cada grupo experimental. 
Imagens dos estômagos do experimento de indução de lesões gástricas por etanol/ $\mathrm{HCl}$

Frações enriquecidas em Flavonóides
C: Caule
F: Folha
CT: Controle(Tween 10\%)
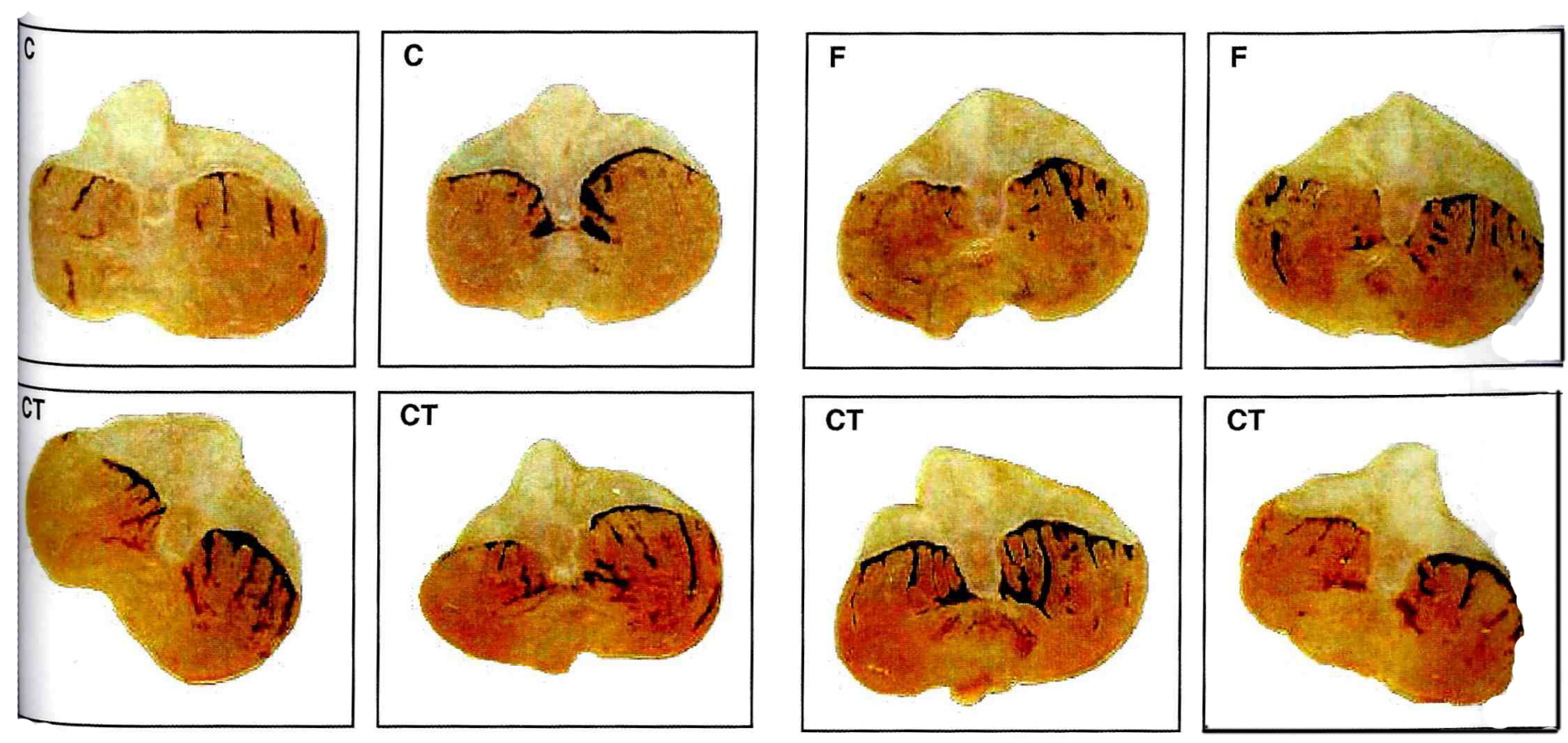

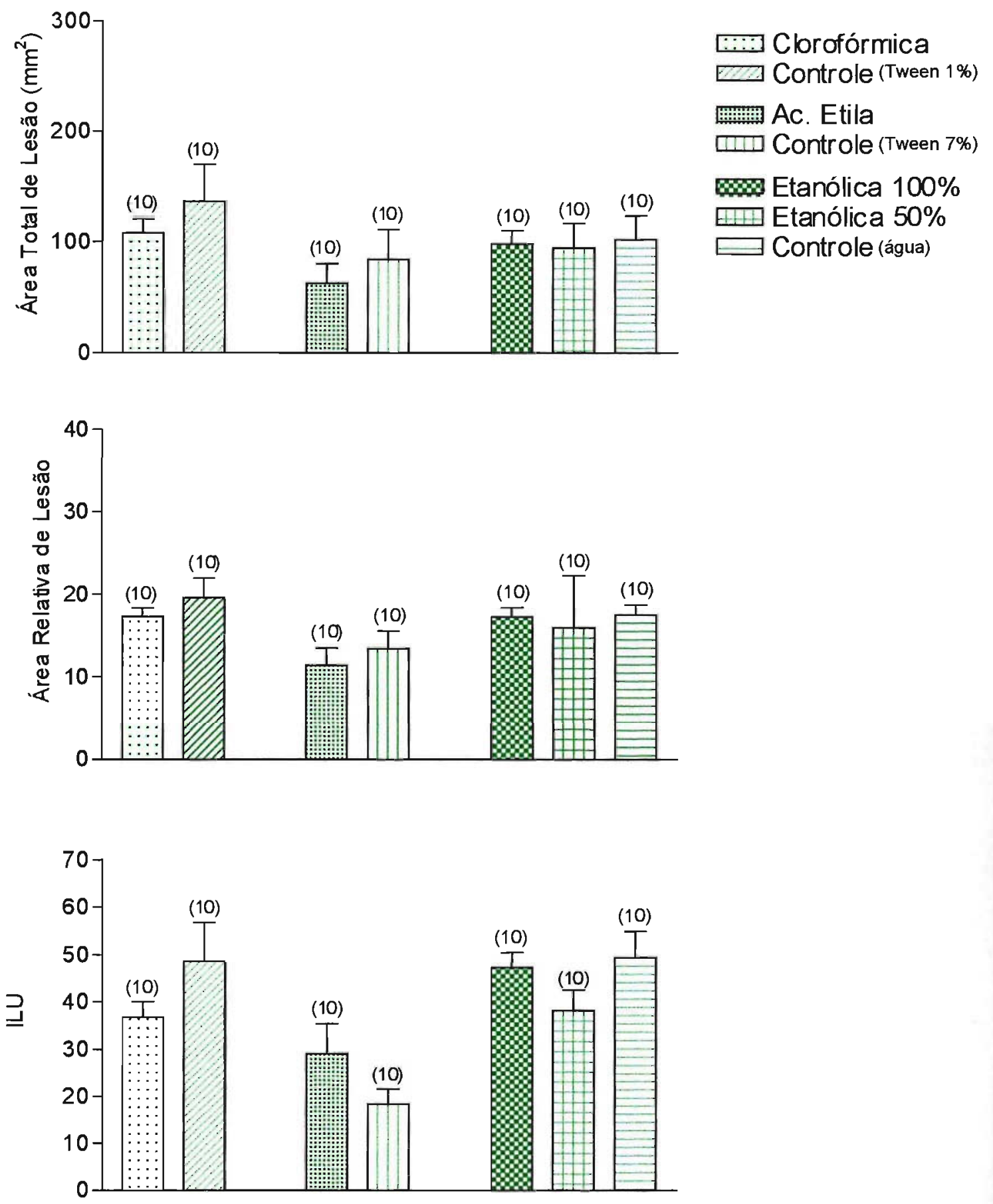

Figura 24: Efeito das frações clorofórmica, acetato de etila, etanólica $100 \%$ e etanólica $50 \%$ de folhas de C. ferrea, $400 \mathrm{mg} / \mathrm{kg}$ (v.o), no modelo de indução gástrica pelo Etanol $(60 \%) / \mathrm{HCl}(0.3 \mathrm{M}), 1 \mathrm{ml} / 100 \mathrm{~g}$ (v.o). No gráfico estão representadas as médias da Área Total de Lesão, da Área Relativa de Lesão e do ILU e seus respectivos erros padrões ( $p<0.05$, ANOVA, Teste de Tukey ou Kruskal Wallis-Dunn). Entre parênteses está representado o número de animais utilizados em cada grupo experimental. 
Imagens dos estômagos do experimento de indução de lesões gástricas por etanol/ $\mathrm{HCl}$.

\section{Frações-Folha}

C: Clorofórmio

T1\%: Tween 1\%

AE: Acetato de Etila

T7\%: Tween 7\%

Et100\%: Etanol 100\%

Et50\%: Etanol 50\%

CT: Controle (água)
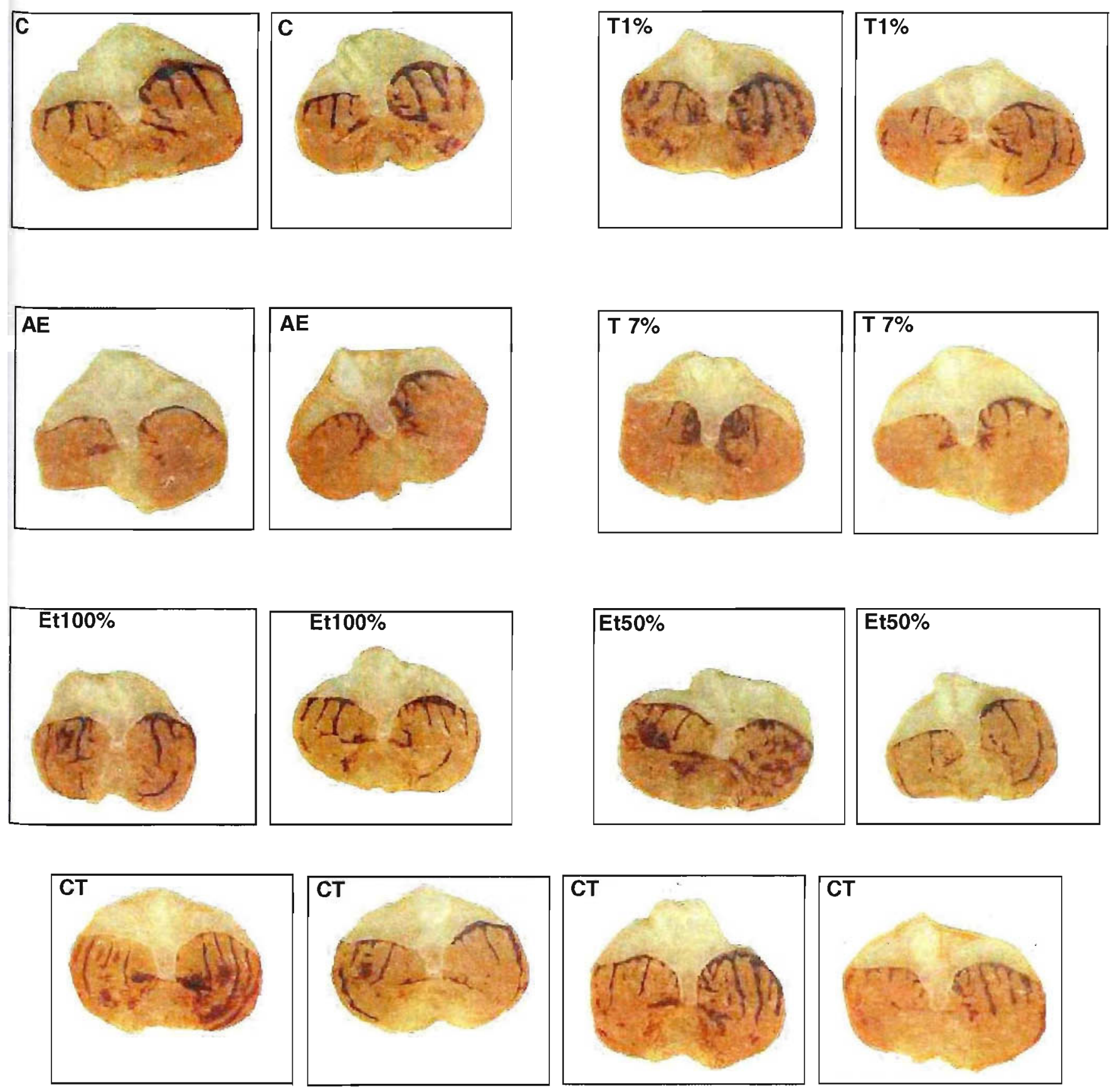

Resultados 

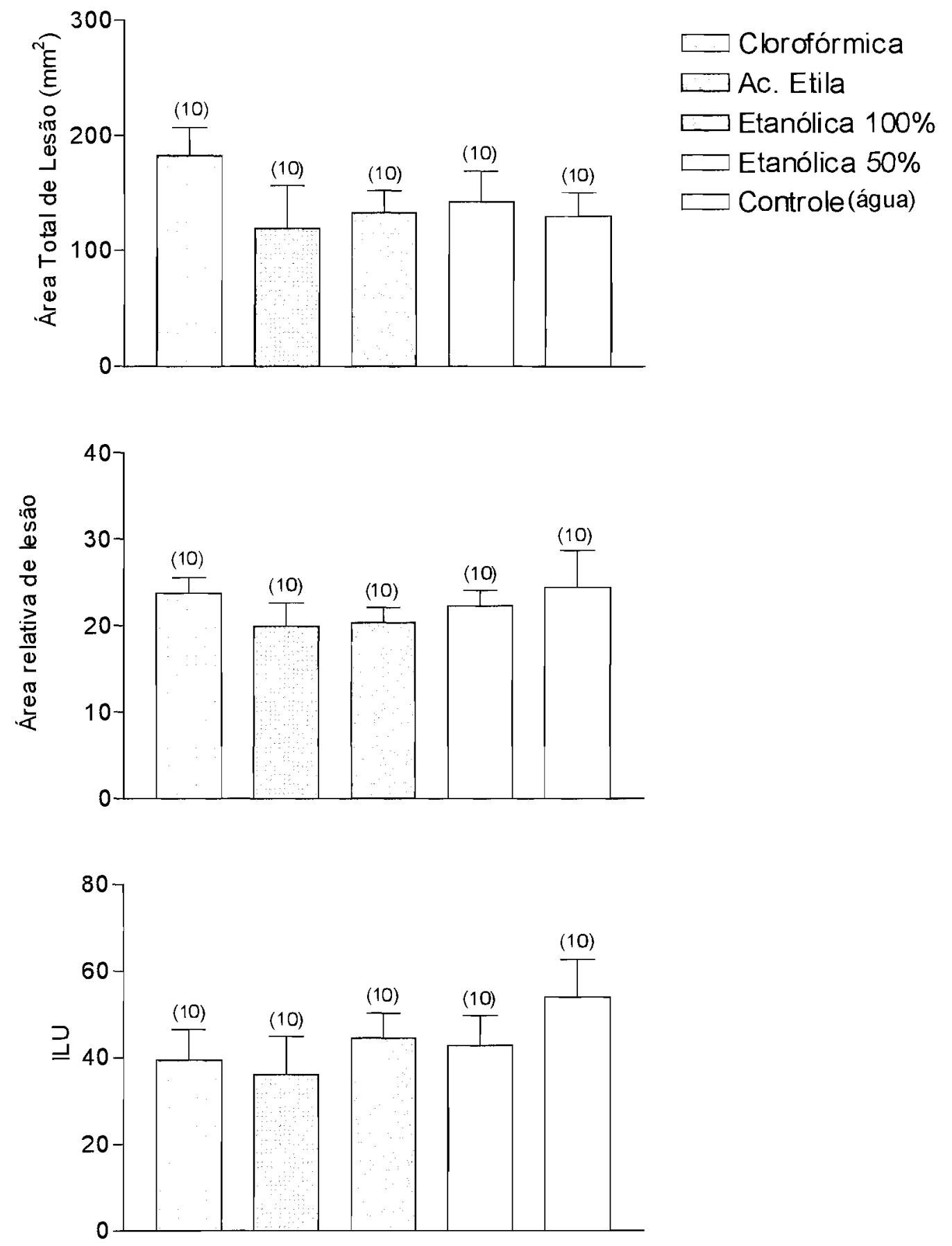

Figura 25: Efeito das frações clorofórmica, acetato de etila, etanólica $100 \%$ e etanólica $50 \%$ de caule de C. ferrea, $400 \mathrm{mg} / \mathrm{kg}$ (v.o), no modelo de indução gástrica pelo Etanol $(60 \%) / \mathrm{HCl}(0.3 \mathrm{M}), 1 \mathrm{ml} / 100 \mathrm{~g}$ (v.o). No gráfico estão representadas as médias da Área Total de Lesão, da Área Relativa de Lesão e do ILU e seus respectivos erros padrões $(p<0.05$, Teste de Tukey ou Kruskal Wallis-Dunn). Entre parênteses está representado o número de animais utilizado em cada grupo experimental. 
Imagens dos estômagos do experimento de indução de lesões gástricas por etanol/ $\mathrm{HCl}$.

\section{Frações-Caule}

C: Clorofórmio

AE: Acetato de Etila

Et100\%: Etanol 100\%

Et50\%: Etanol 50\%

CT: Controle (água)
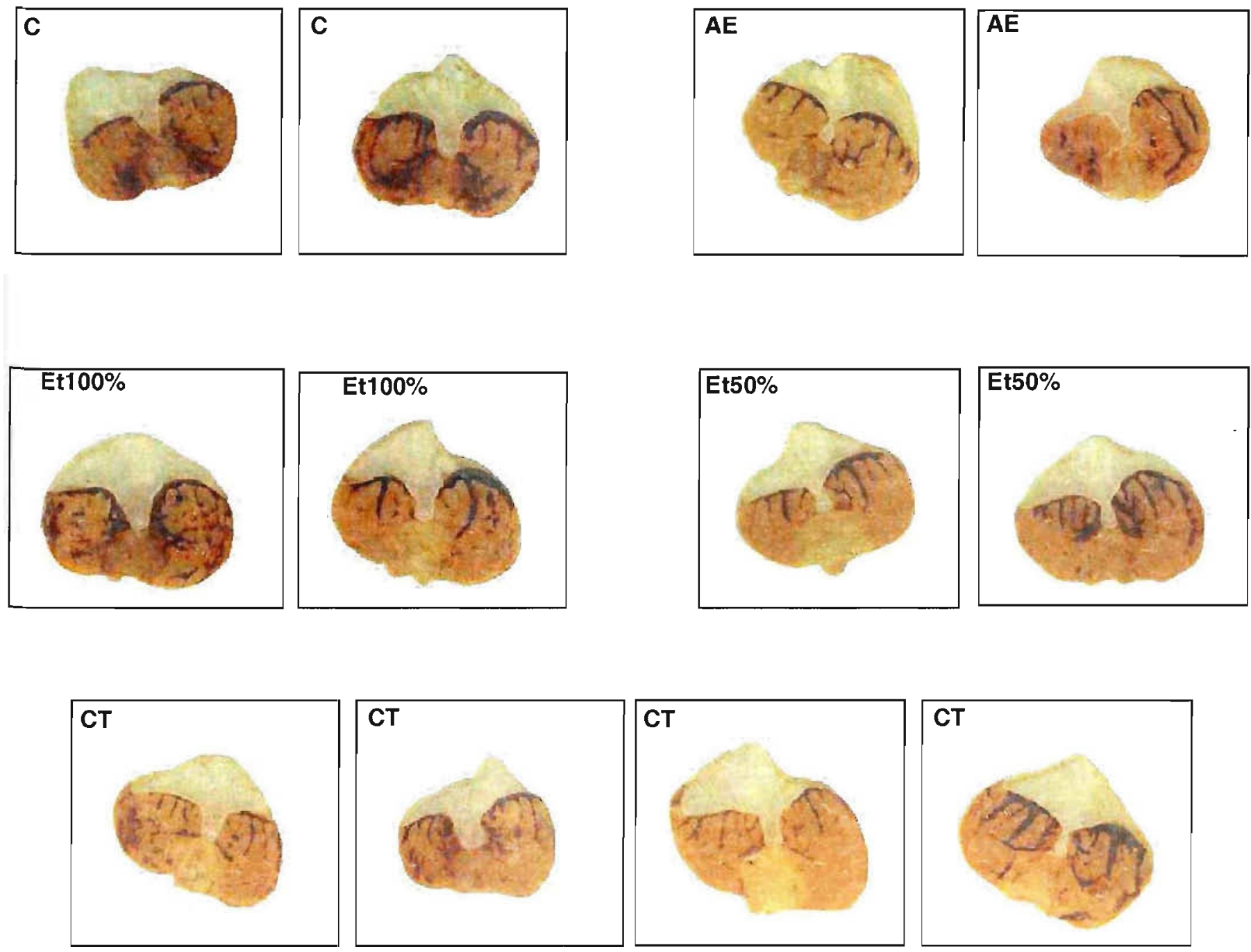

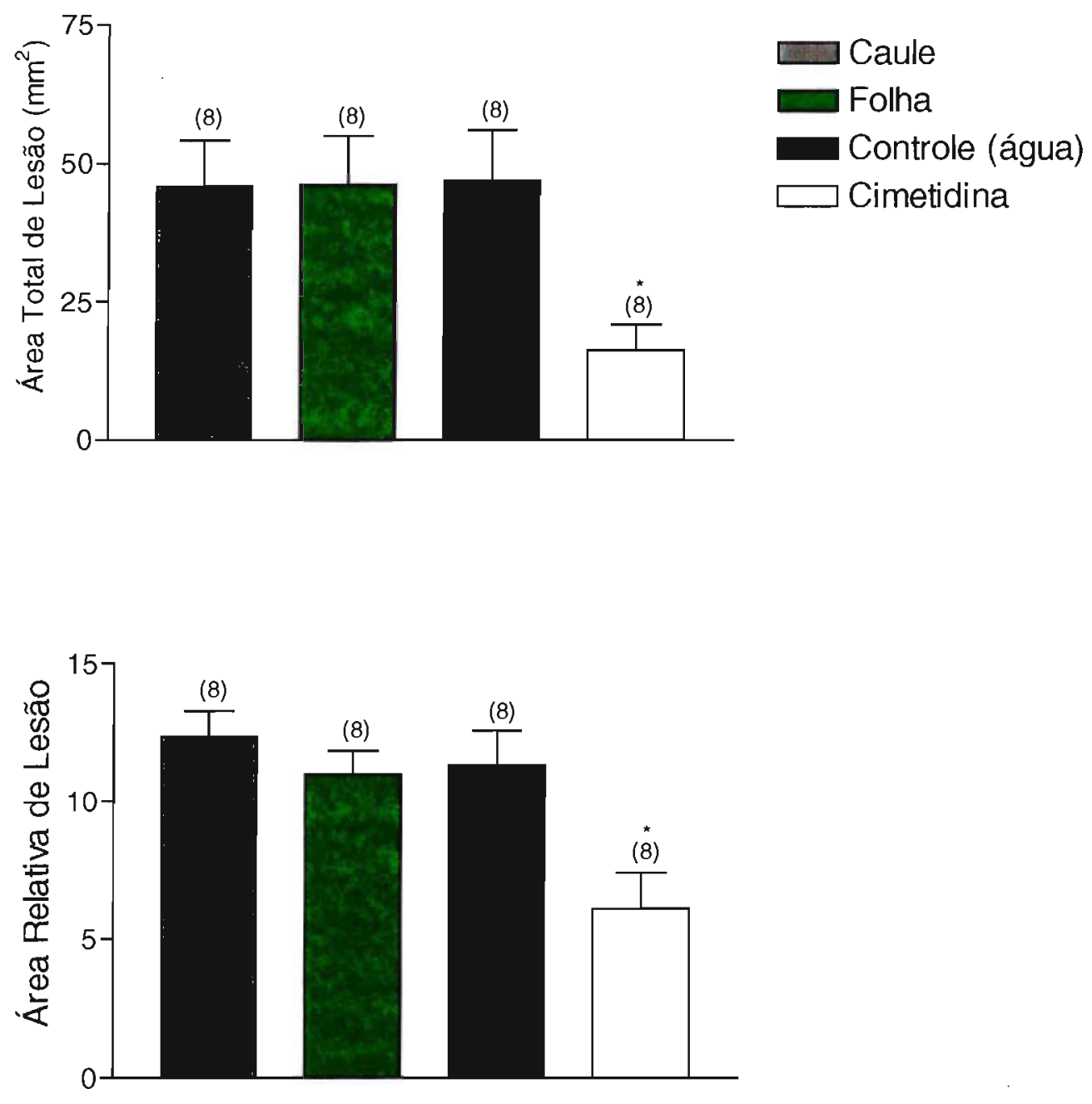

Figura 26: Efeito dos extratos de caule e folha de C. ferrea, $200 \mathrm{mg} / \mathrm{kg}$ (v.o), no modelo de indução gástrica pelo Ácido Acético $30 \%$. No gráfico estão representadas as médias da Área Total de Lesão e da Área Relativa de Lesão e seus respectivos erros padrões ( ${ }^{*} p<0.05$, ANOVA, Teste de Tukey). Entre parênteses está representado o número de animais utilizado em cada grupo experimental. 
Imagens dos estômagos do experimento de indução de lesões gástricas por ácido acético

C: Caule $(200 \mathrm{mg} / \mathrm{kg})$

F: Folha $(200 \mathrm{mg} / \mathrm{kg})$

CT: Controle

FR: Fármaco de referência (Cimetidina)
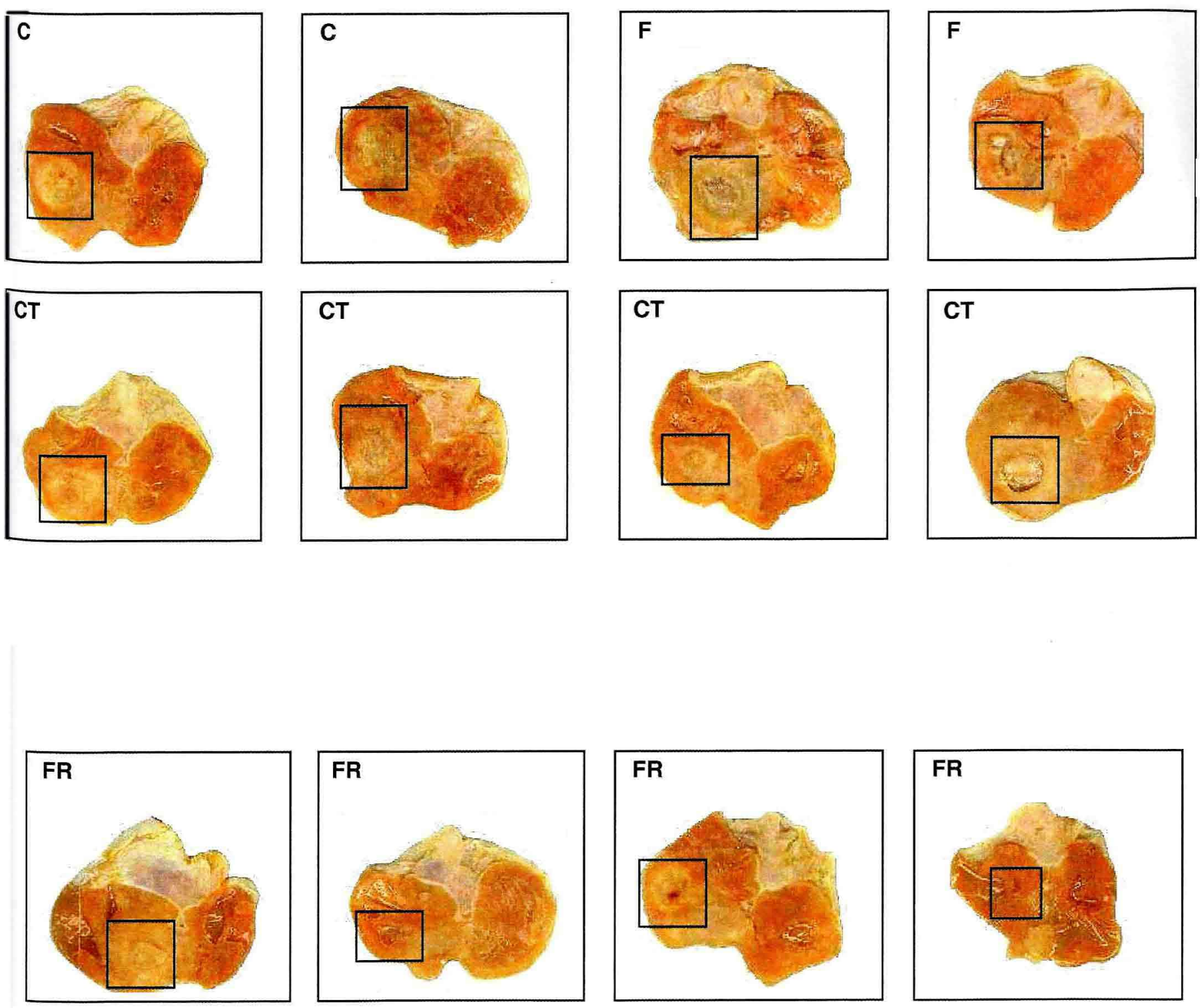


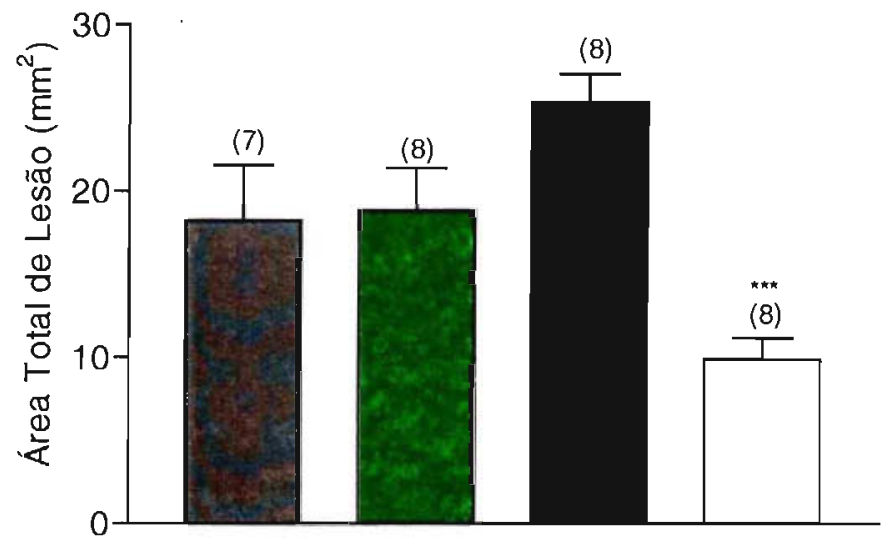

$\square$ Caule

$\square$ Folha

Controle (água) $\square$ Cimetidina

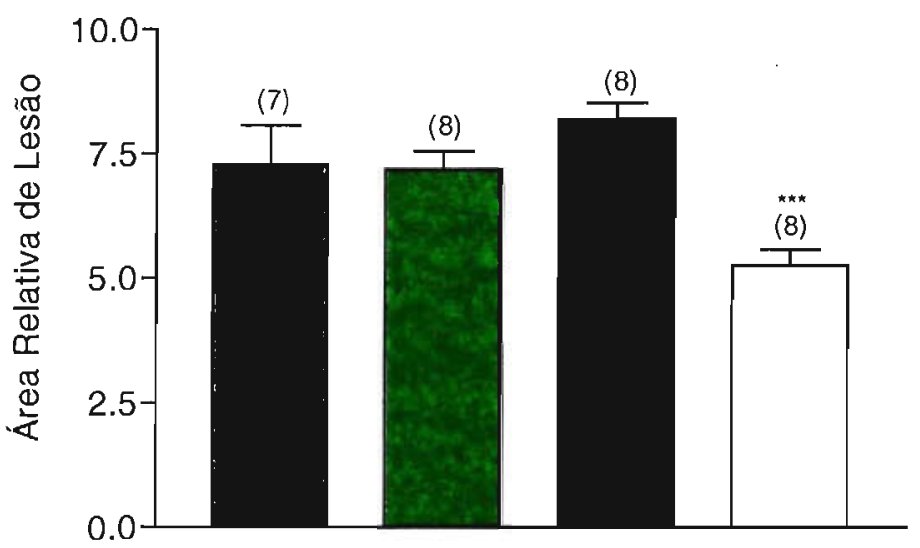

Figura 27: Efeito dos extratos de caule e folha de C. ferrea, $400 \mathrm{mg} / \mathrm{kg}$ (v.o), no modelo de indução gástrica pelo Ácido Acético $30 \%$. No gráfico estão representadas as médias da Área Total de Lesão e da Área Relativa de Lesão e seus respectivos erros padrões $\left({ }^{* * *} p<0.001\right.$, ANOVA, Teste de Tukey). Entre parênteses está representado o número de animais utilizado em cada grupo experimental. 
Imagens dos estômagos do experimento de indução de lesões gástricas por ácido acético

C: Caule $(400 \mathrm{mg} / \mathrm{kg})$

F: Folha $(400 \mathrm{mg} / \mathrm{kg})$

CT: Controle

FR: Fármaco de referência (Cimetidina)
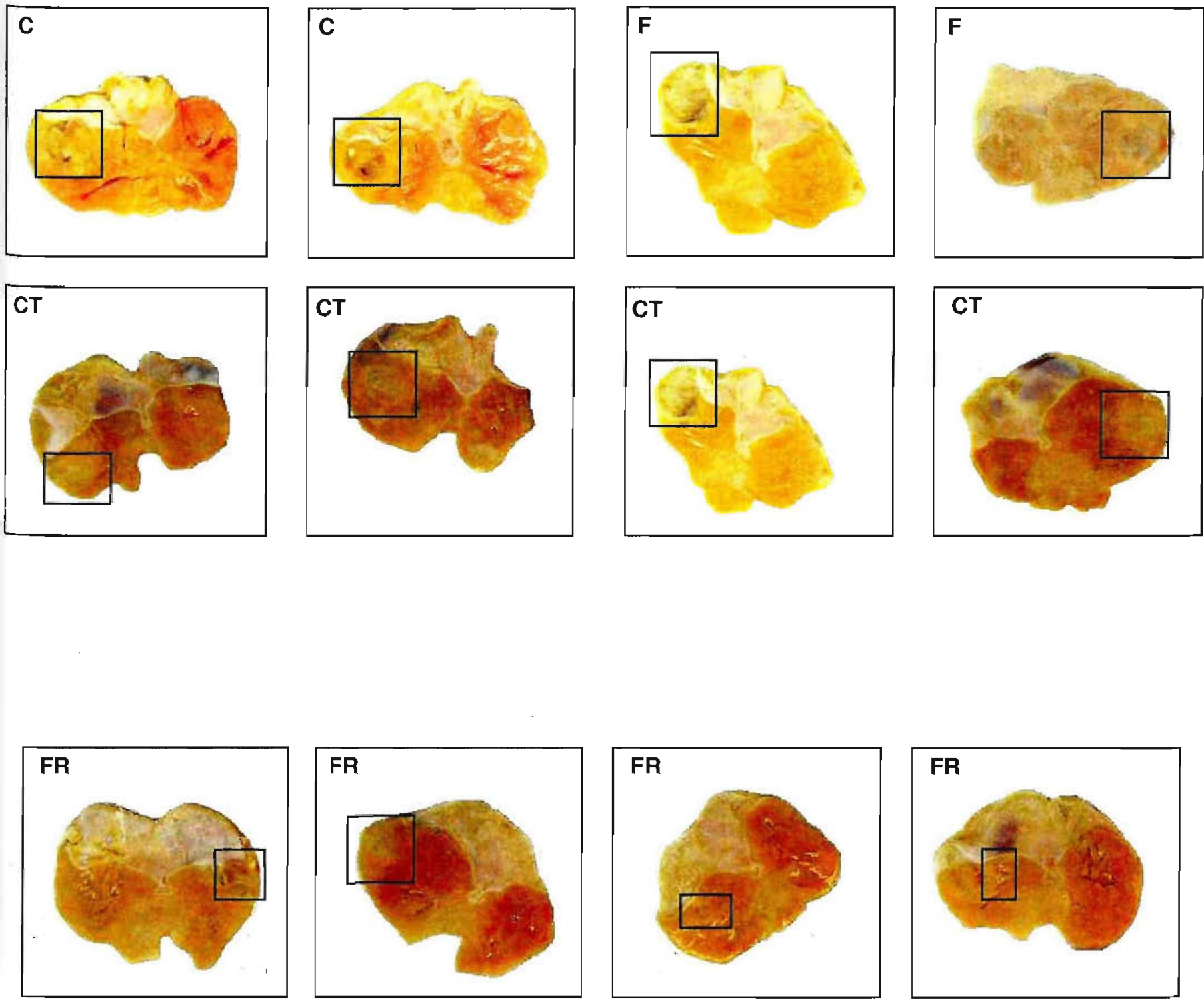


\subsection{ATIVIDADE ANTTIOXIDANTE}

Os valores representam a média de 4 determinações (CAOx padrão) de substâncias reagentes com o ácido tiobarbitúrico (TBARs) e estão apresentados na Tabela 8 e 9 e Figuras 28 e 29.

Tabela 8: Capacidade Antioxidante (CAOx\%) dos extratos brutos liofilizados de folhas e caule de $C$. ferrea na lipoperoxidação de cérebro de rato.

\begin{tabular}{cccc}
\hline & $\begin{array}{c}\text { Capacidade } \\
\text { Antioxidante CAOx } \\
(\%)\end{array}$ & $\begin{array}{c}\text { 1/Concentração do } \\
\text { extrato }(\mu \mathrm{g} / \mathrm{mL})\end{array}$ & $1 /$ CAOX\% \\
\hline \multirow{2}{*}{ FOLHAS } & $93,56 \pm 0,44$ & 1,22 & 0,0107 \\
$73,00 \pm 0,97$ & 2,44 & 0,0137 \\
& $44,47 \pm 0,57$ & 4,88 & 0,0225 \\
& $28,95 \pm 0,95$ & 9,76 & 0,0345 \\
& $13,82 \pm 0,66$ & 19,52 & 0,0724 \\
\hline \multirow{2}{*}{ AUL1E } & $84,38 \pm 0,87$ & 1,22 & 0,0118 \\
& $54,64 \pm 1,10$ & 2,44 & 0,0183 \\
& $27,58 \pm 0,89$ & 4,88 & 0,0362 \\
& $16,22 \pm 0,90$ & 9,76 & 0,0616 \\
& $11,35 \pm 0,97$ & 19,52 & 0,0881 \\
\hline
\end{tabular}


A

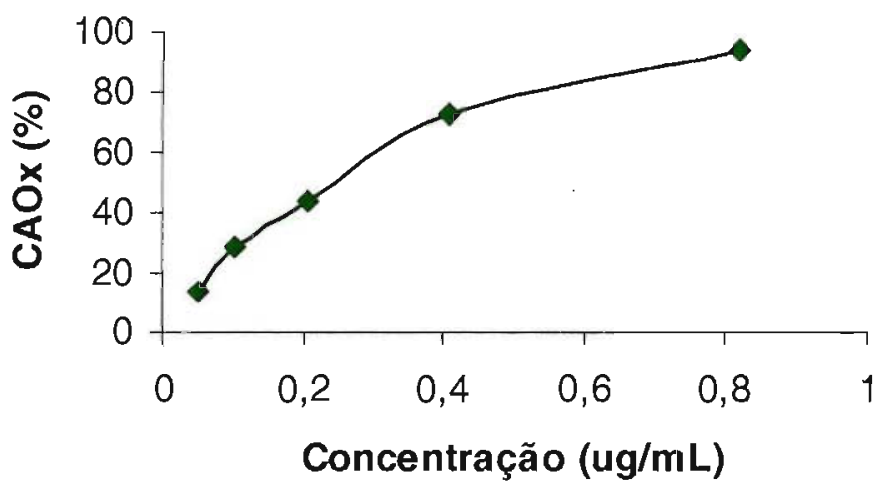

B

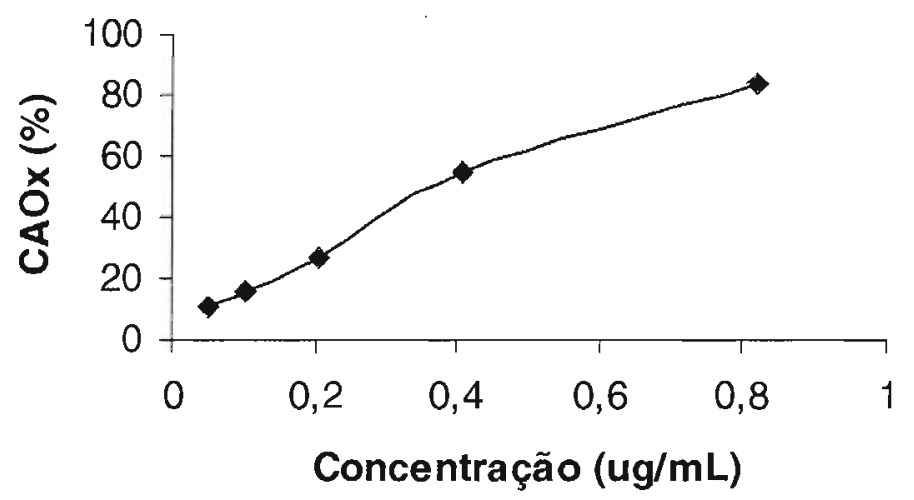

Figura 28: Capacidade Antioxidante dos Extratos brutos liofilizados de folhas (A) e caule (B) de C.ferrea no ensaio de lipoperoxidação de homogenato de cérebro de ratos. 
A

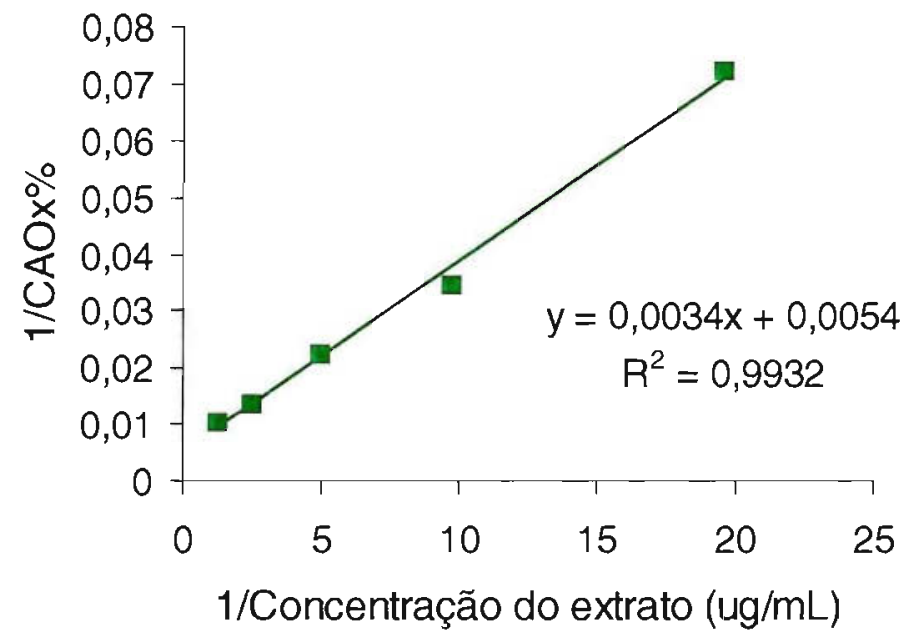

B

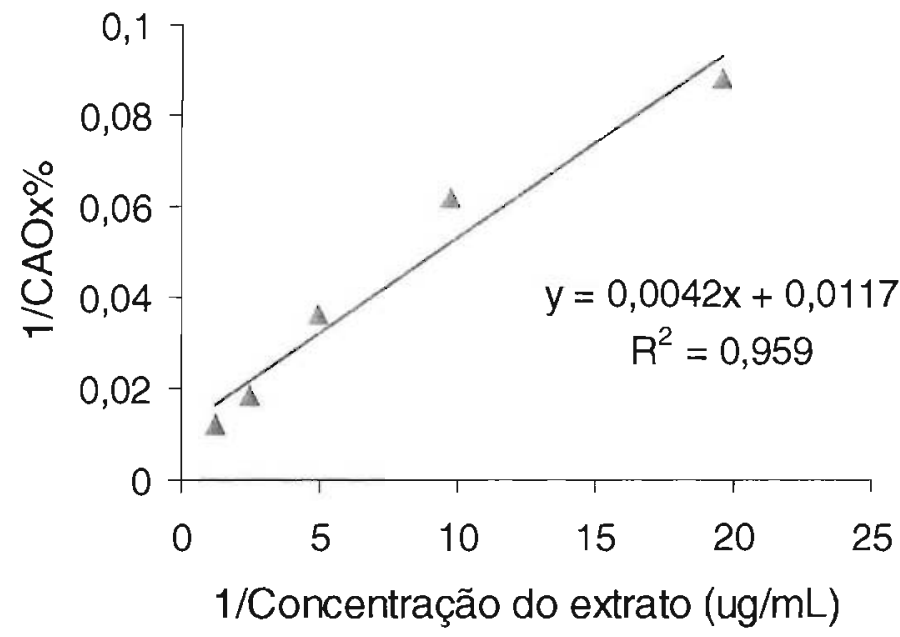

Figura 29: Capacidade Antioxidante dos Extratos brutos liofilizados de folhas (A) e caule (B) de C.ferrea no ensaio de lipoperoxidação de homogenato de cérebro de ratos. 
Tabela 9: Cálculo de $Q_{1 / 2}$ (concentração necessária para atingir $50 \%$ da Capacidade Antioxidante) dos Extratos brutos liofilizados de folhas e caule de C. ferrea na lipoperoxidação de cérebro de rato.

Equação da reta: $y=a+b x$

\begin{tabular}{|c|c|}
\hline \multirow[t]{5}{*}{ Folhas } & $a=0,0054$ \\
\hline & $b=0,0034$ \\
\hline & Regressão linear $\left(\mathrm{R}^{2}\right): 0,9932$ \\
\hline & $y=1 / 50=0,0054+0,0034 x$ \\
\hline & $Q_{1 / 2}=0,2331 \mu \mathrm{g} / \mathrm{mL}$ \\
\hline \multirow[t]{5}{*}{ Cante } & $a=0,0042$ \\
\hline & $b=0,0117$ \\
\hline & Regressão linear $\left(R^{2}\right): 0,959$ \\
\hline & $y=1 / 50=0,0117+0,0042 x$ \\
\hline & $Q_{1 / 2=} 0,5061 \mu \mathrm{g} / \mathrm{mL}$ \\
\hline
\end{tabular}




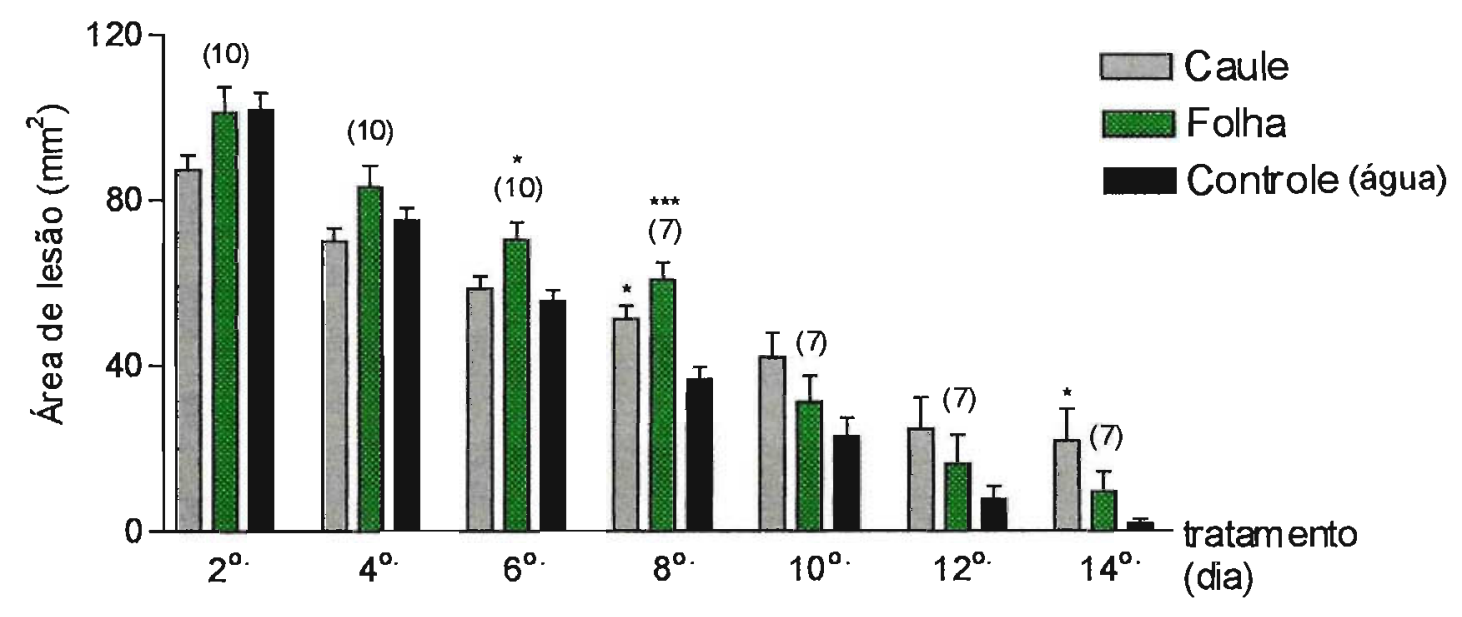

Figura 30: Efeito dos extratos brutos de folhas e caule de C. ferrea, $15 \%$ em água, via tópica, no modelo de atividade cicatrizante. No gráfico estão representadas as médias das lesões $\left(\mathrm{mm}^{2}\right)$ e seus respectivos erros padrão ( ${ }^{\star} p<0.05 ;{ }^{\star \star \star} p<0.001$; Teste de Tukey) no $2^{\circ}, 4^{\circ}, 6^{\circ}, 8^{\circ}, 10^{\circ}, 12^{\circ}$ e $14^{\circ}$ dia após a incisão. Entre parênteses está representado o número de animais em cada grupo experimental. 


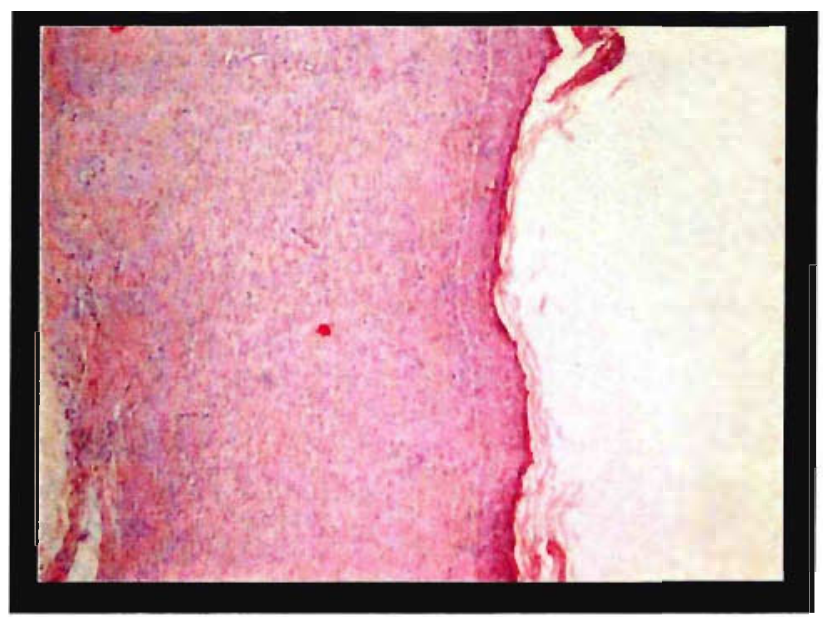

Figura 31: Fotomicrografia de corte histológico de pele de animal controle, com 15 dias de evolução, mostrando reparação epitelial, com formação de epitélio pavimentoso estratificado queratinizado. $\mathrm{Na}$ derme subjacente, nota-se reparação por cicatrização. Coloração: hematoxilina-eosina (HE). Aumento:40x.

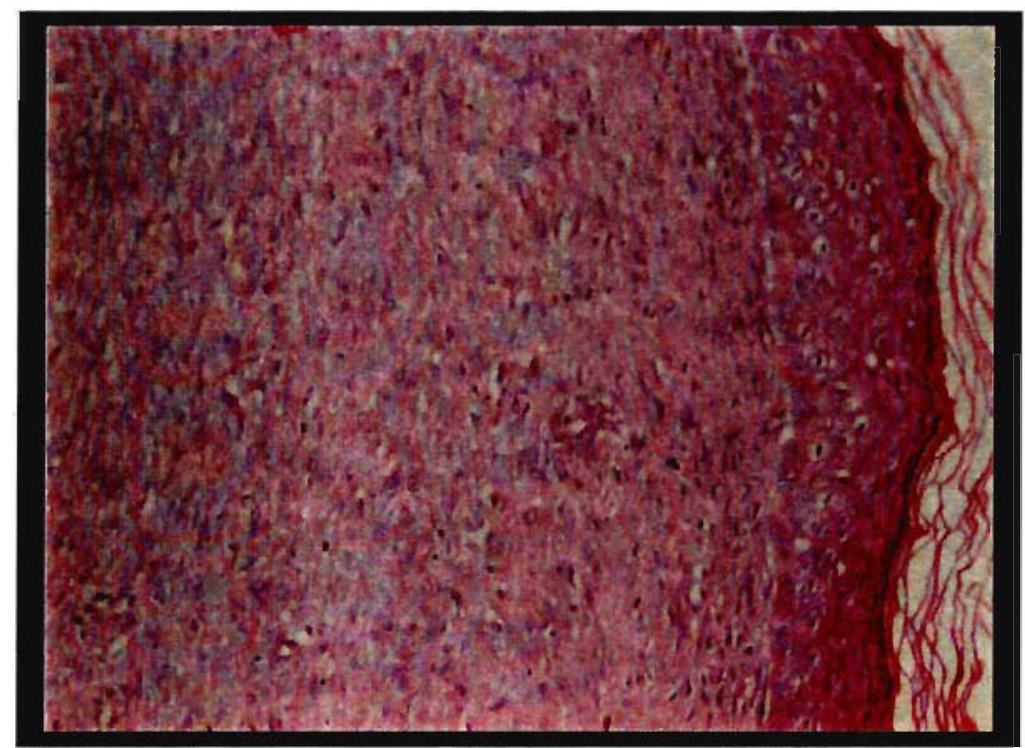

Figura 32: Detalhe em maior aumento da fotomicrografia anterior, evidenciando o epitélio regenerado e a área de reparação, com escassez de fibroblastos, alguns fibrócitos e grande quantidade de colágeno. Nota-se resquícios de vasos neoformados. Coloração: HE. Aumento: 100x. 


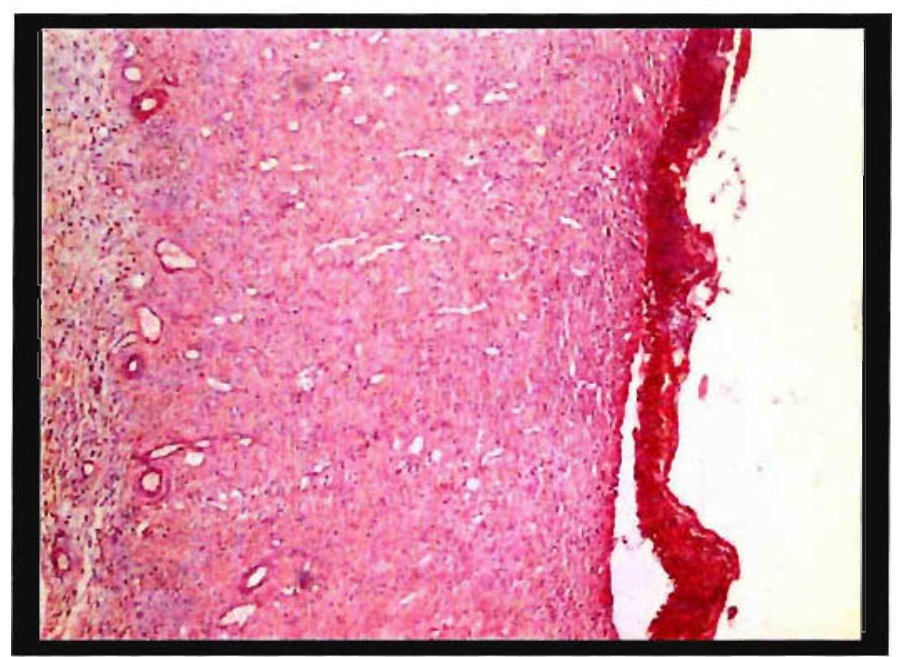

Figura 33: Fotomicrografia de corte histológico de pele de rato tratado com extrato de caule de $C$. ferrea, com 15 dias de evolução, mostrando falta de regeneração epitelial, derme subjacente com vasos neoformados, alta celularidade e colágeno desorganizado. Coloração: HE. Aumento:4x.

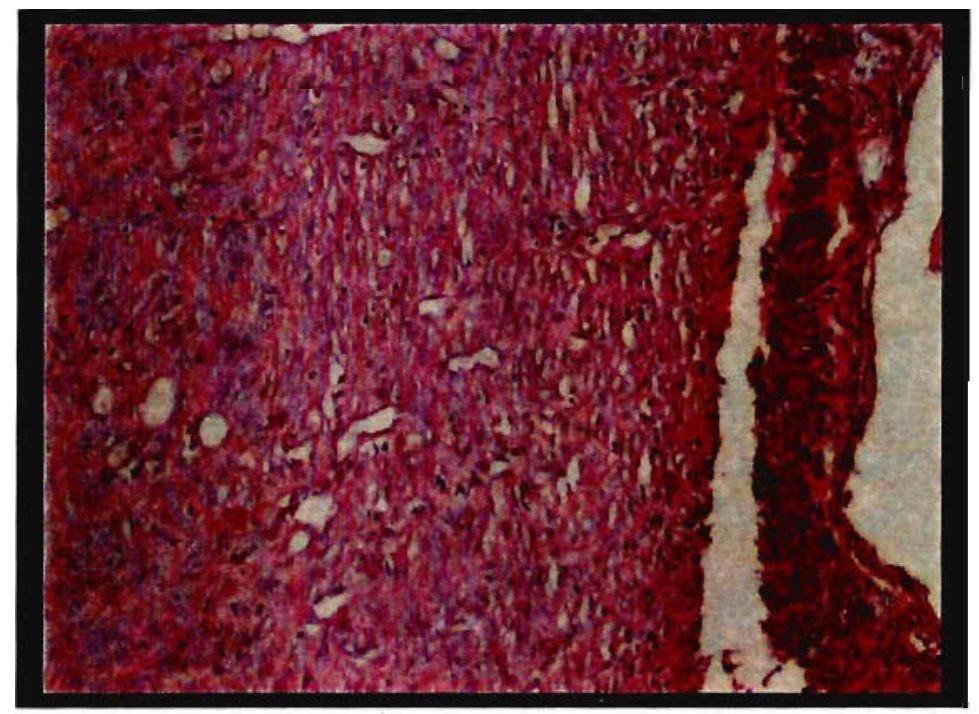

Figura 34: Fotomicrografia de corte histológico de pele de animal tratado com extrato de caule de $C$. ferrea, com 15 dias de evolução, mostrando tentativa de regeneração epitelial. $\mathrm{Na}$ derme subjacente, nota-se tecido de granulação, com grande quantidade de vasos neoformados, fibroblastos, fibrócitos e colágeno desorganizado. Coloração: HE. Aumento:100x. 


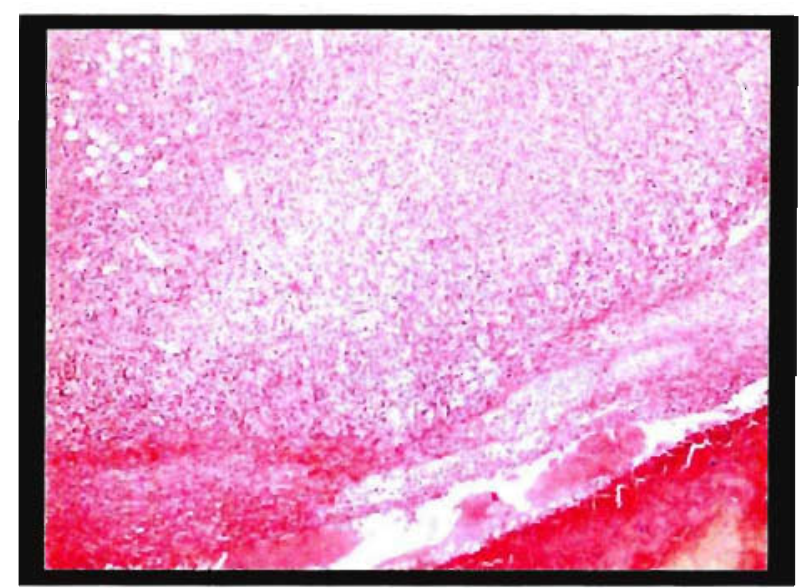

Figura 35: Fotomicrografia de corte histológico de pele de rato, tratado com extrato de folha de $C$. ferrea, com 15 dias de evolução, mostrando ausência de regeneração epitelial. $\mathrm{Na}$ derme subjacente, nota-se tecido de granulação com escassez de colágeno. Coloração: HE. Aumento: 4x.

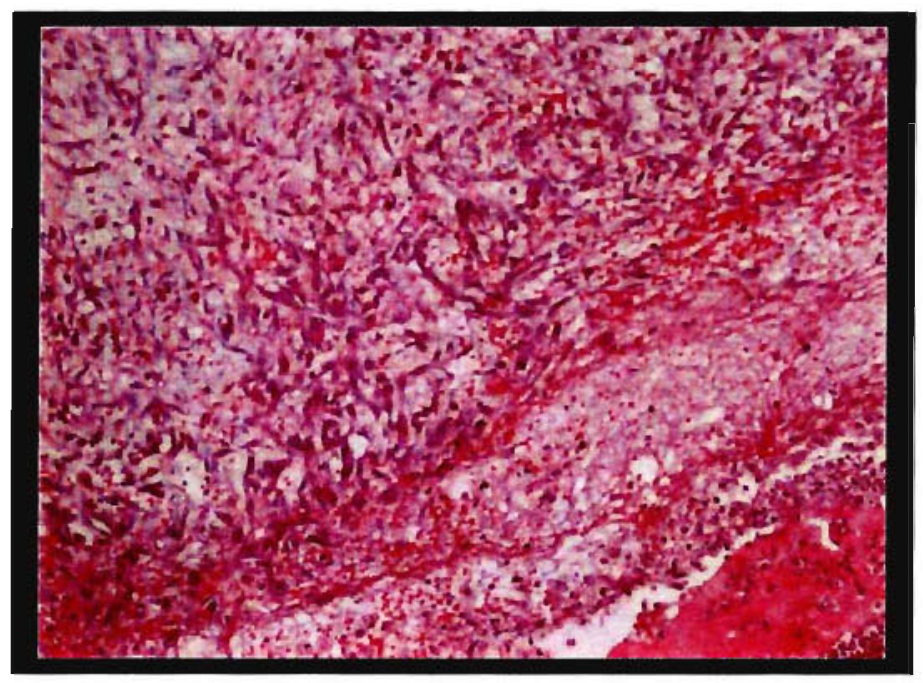

Figura 36: Detalhe em maior aumento da fotomicrografia anterior, evidenciando tecido de granulação com exuberância de vasos neoformados, grande quantidade de fibroblastos. $\mathrm{Na}$ superfície, à direita, nota-se ausência de regeneração epitelial. Coloração: HE. Aumento: 100x. 


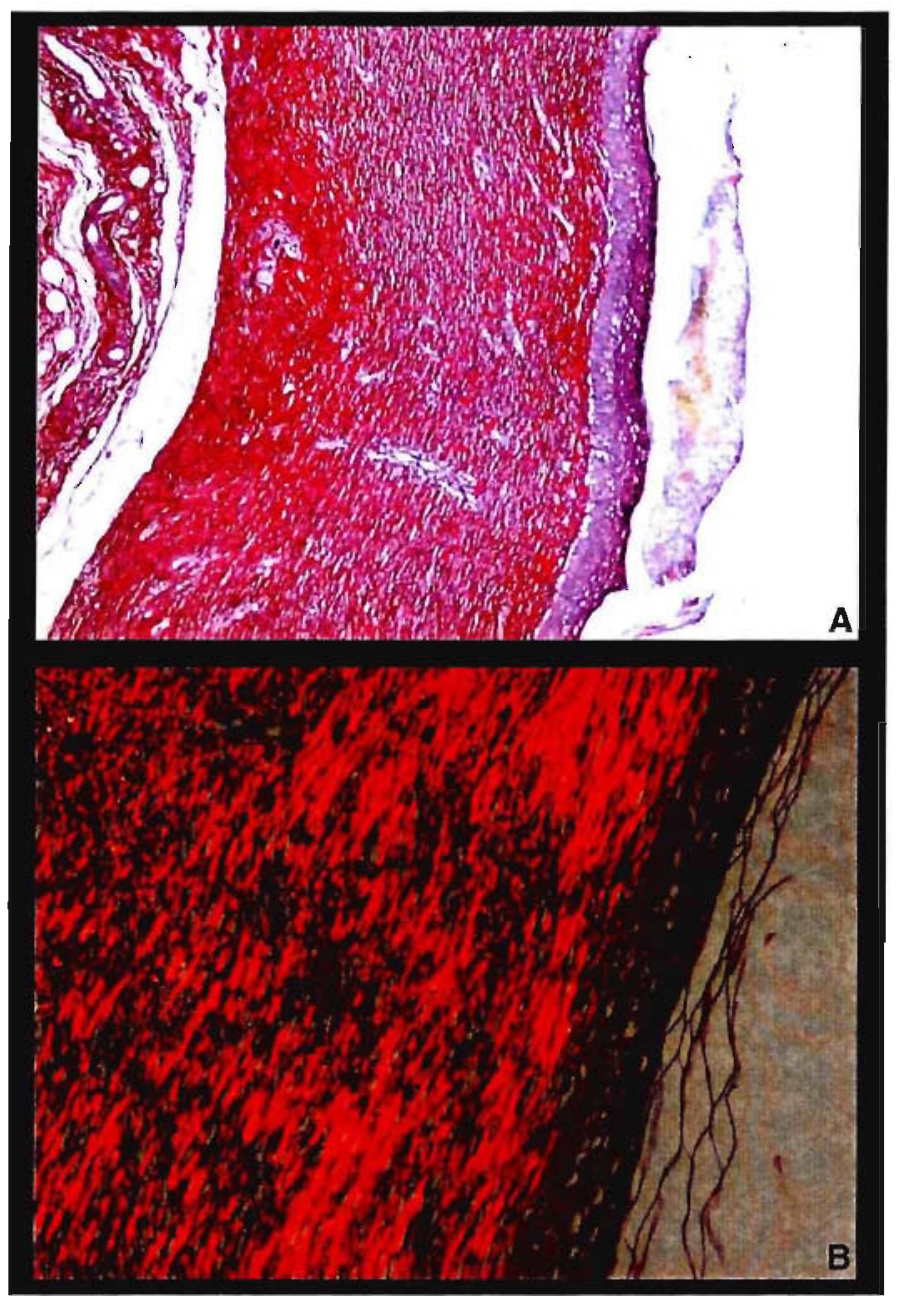

Figura 37: Fotomicrografias de cortes histológicos de pele de animal controle com 15 dias de evolução A) corado pelo Picro sírius, evidenciando colágeno. B) corado com Picro sírius em luz polarizada, destacando o colágeno da área de reparação por cicatrização. Aumento: 40x. 

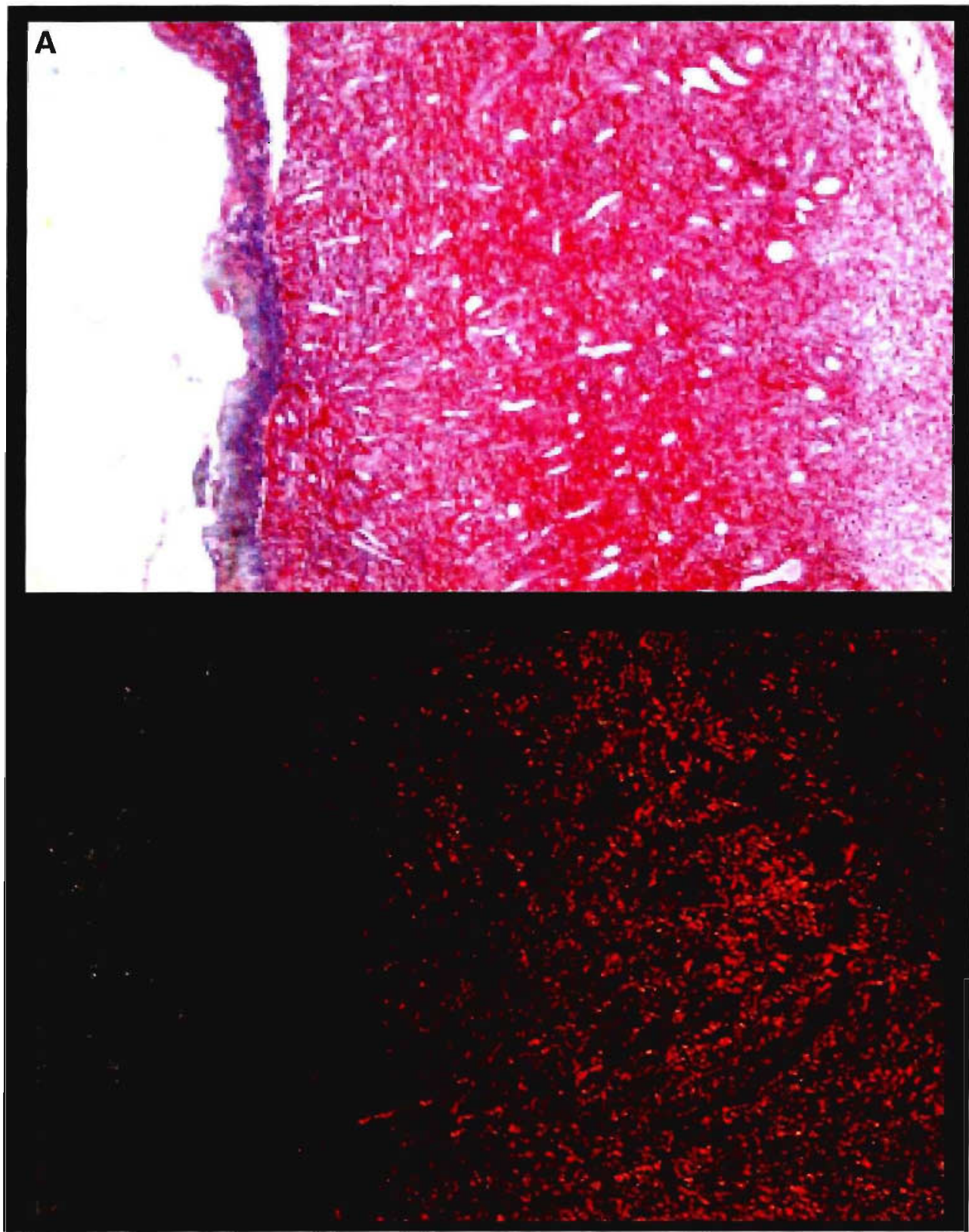

Figura 38: Fotomicrografia de corte histológico de pele de rato tratado com extrato de caule de $C$. ferrea com 15 dias de evolução A) corado pelo Picro sírius, evidenciando colágeno. B) corado com Picro sírius em luz polarizada, destacando 0 colágeno. Aumento: 40x. 


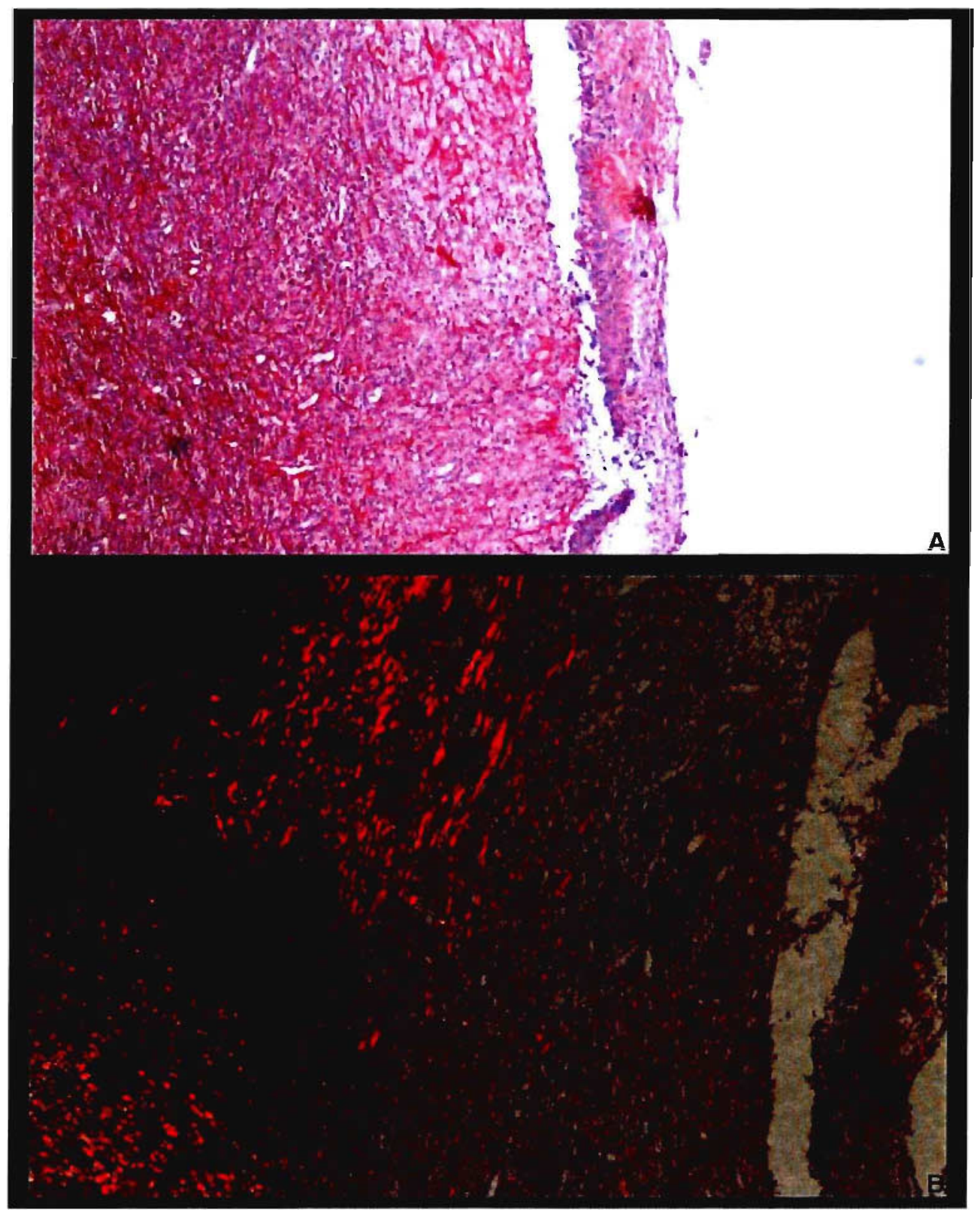

Figura 39: Fotomicrografia de corte histológico de pele de rato tratado com extrato de folha de $C$. ferrea com 15 dias de evolução A) corado pelo Picro sírius, mostrando quantidade escassa de colágeno na área de reparação. B) corado com Picro sírius em luz polarizada, mostrando pequena quantidade de colágeno na área de reparação. Aumento: 40x. 
Quanto ao estudo histopatológico da evolução do processo de reparação por cicatrização e regeneração, pudemos observar que o grupo controle exibiu delimitação perfeita entre as extremidades normais de pele com área central mostrando os fenômenos biológicos, morfológicos da reparação como, por exemplo, a formação de epitélio sobre a área de cicatrização que apresentou múltiplas camadas de células, comparando-o com o epitélio vizinho normal, quadro de hiperplasia (acantose), devido estar bem mais espessado. Verificouse também a presença de camada delgada de queratina na superfície. $\mathrm{Na}$ derme subjacente foram evidenciados elementos que compõem o quadro de reparação por cicatrização, onde se observou formação de extensa quantidade de tecido conjuntivo, rico em fibras colágenas, nas quais estas apresentaramse densas, relativamente bem organizadas, formando feixes paralelos, de entremeio a fibroblastos e fibrócitos. Houve ainda, vasos neoformados na região, contudo, em pequeno número (Figuras 31 e 32). Através de lâminas coradas pelo Picro sírius, foram evidenciadas as fibras colágenas e seu nível de organização, bem como a densidade com que se apresentam (Figuras 37).

Nos cortes histológicos de pele do Grupo Tratado com o extrato bruto liofilizado de Caule de $C$. ferrea não se observou resposta epitelial regenerativa em todos os exemplares examinados. Em apenas um dos animais foi observada resposta regenerativa do epitélio, contudo, a espessura do mesmo apresentou-se mais delgada que o do controle. As diferenças mais evidentes deste grupo em relação ao Grupo Controle, foram observadas no tecido conjuntivo da derme, onde a reparação deu-se de maneira muito menos eficiente em termos de avaliação histopatológica. Notou-se que houve a formação de uma quantidade bem menor de tecido conjuntivo, pela falta de densidade de fibras colágenas. Ocorreu grande quantidade de vasos neoformados, o que não deveria haver para esse tempo de evolução da reparação (15 dias) (Figuras 33 e 34). Observando-se lâminas coradas com Picro sírius notou-se com evidência a escassez de fibras, bem como seu baixo nível de organização (Figura 38).

Da mesma forma, o Grupo Tratado com extrato bruto liofilizado de Folha de $C$. ferrea exibiu um quadro predominantemente composto por falta de resposta regenerativa epitelial, tendo sido observado apenas um caso com regeneração. A resposta do tecido conjuntivo da derme, no que concerne à 
formação do tecido de granulação, apresentou grande quantidade de vasos neoformados, não compatíveis com 15 dias de evolução e, da mesma forma, deposição de fibras colágenas a menos do que deveria ocorrer. Quanto a organização das mesmas, essas diferiram do Grupo Controle por estarem mal organizadas (Figuras 35 e 36). A coloração de Picro sírius evidenciou o presente fato (Figura 39). 


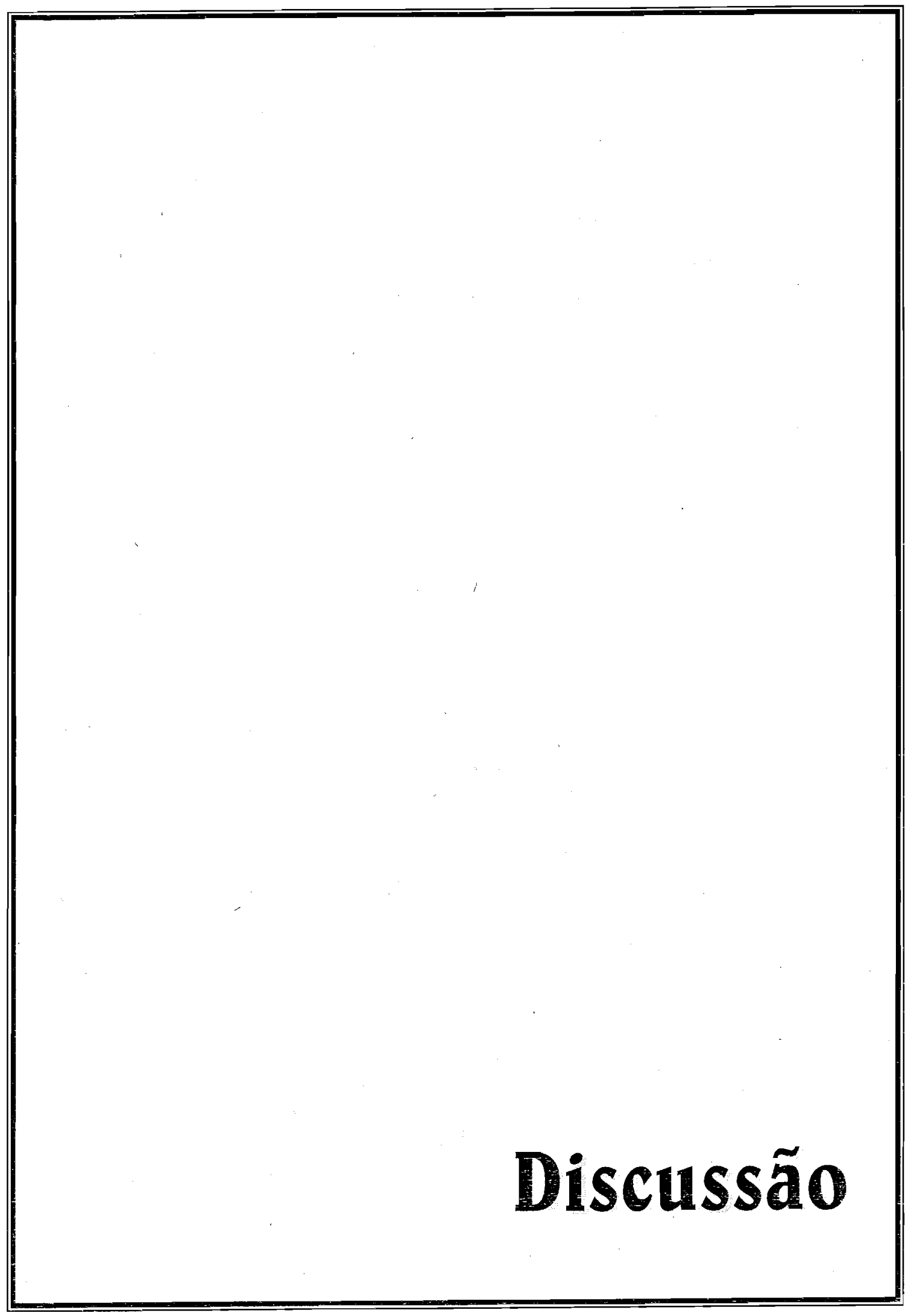




\section{Discussão}

O gênero Caesalpinia (Leguminosae- Caesalpinioideae), apresenta inúmeras espécies medicinais com uso em diversos países, das quais se destacam C. bonduc, C. bonducella; C. sapan e C. pulcherrima (Di Stasi, HirumaLima et al., 2002).

Caesalpinia ferrea Mart, conhecida como pau-ferro, jucá, é uma das espécies mais conhecidas e empregadas na medicina popular brasileira. É utilizada como desobstruente, analgésica, antiinflamatória, anti-diabética e, principalmente, como antiulcerogênica (Corrêa, 1984; Di Stasi, Hiruma- Lima et al., 2002). Apesar dessas inúmeras aplicações terapêuticas, poucas pesquisas já foram realizadas com esta espécie vegetal, sendo justificável, portanto, estudos para seu melhor conhecimento.

Alguns dos aspectos morfológicos da família Leguminosae, subfamília Caesalpinoideae, descritos por Joly (1966) e importantes no reconhecimento da espécie tema da dissertação, quando da sua coleta são: árvores de grande porte (Figura 3A), folhas compostas e bipinadas, paripinadas, folíolos com pulvino na base (Figura 3B-C). Uma característica não descrita pelo autor, mas que merece grande destaque é o tronco cinéreo acrescido de manchas esbranquiçadas alongadas longitudinalmente (Figura $3 \mathrm{~A}, D$ ). Tal caracter morfológico sobressai quando comparado aos demais já citados, podendo até ser considerado um "marcador diferencial" dessa espécie vegetal entre as demais pertencentes ao mesmo gênero.

Resultados semelhantes aos anteriores foram obtidos no estudo anatômico do presente trabalho, no qual várias estruturas da família Leguminosae e do gênero Caesalpinia descritas por Metcalfe e Chalk (1964) foram detectadas. Podem ser citados como exemplo, nas folhas, a presença de tricomas glandulares na face abaxial, cristais de oxalato de cálcio (drusas e cristais prismáticos) no mesofilo e feixes vasculares acompanhados de esclerênquima e, no caule, feixes vasculares com anel esclerenquimático muitas vezes acompanhado externamente 
por bainha de células contendo cristais isolados (Figura 9A, 10A,B, 11A), floema secundário com cristais isolados (Figura 11A,B,D); vasos do xilema tipicamente solitários com alguns múltiplos de 2 ou 3 células (Figura 12A,B).

O estudo da anatomia revelou algumas características importantes, como a presença de inclusões celulares inorgânicas (drusas) na feloderme (Figura $9 B$ ), o que não havia sido descrito para outras espécies do gênero.

Além disso, nas folhas, foi encontrado mesolilo constituído de 4 a 5 camadas de parênquima paliçádico (Figura 4 A-B, 7 A), dado este que contradiz parcialmente o resultado descrito por Silva et al. (1997) e totalmente o apresentado por Curtis et al. (1996), visto que Silva et al. (1997) expõem mesofilo dorsiventral ( 2 camadas de parênquima paliçádico e 2 camadas de parênquima lacunoso) ou isobilateral (4 camadas de parênquima paliçádico), dependendo da porção da lâmina em que se efetua o corte transversal. Já, Curtis et al. (1996) traça mesofilo apenas dorsiventral.

Resultados semelhantes também puderam ser observados no trabalho descrito por Myers et al. (1987), onde folhas de Castanospermum australe (Fabaceae) de três ambientes diferentes (sombra, sol e intermediário) apresentaram a mesma diferença na distribuição de parênquima paliçádico e/ou lacunoso no mesofilo. Folhas de sombra exibiram parênquima lacunoso com grandes espaços intercelulares. Folhas de habitat intermediário apresentaram parênquima lacunoso com espaços intercelulares menores e poucas camadas de parênquima paliçádico com células menores, e as de sol, parênquima paliçádico bem desenvolvido e menos camadas de parênquima lacunoso.

Estas diferenças talvez possam ser compreendidas por meio das influências dos fatores externos ambientais, visto que esses podem vir a causar mudanças anatômicas, morfológicas e químicas nos vegetais (Myers et al., 1987; Mendes et al., 2001; Oguchi et al., 2003).

Um dos fatores que pode estar diretamente relacionado a estas mudanças é o nível de luminosidade e radiação. É sabido que folhas que recebem alta luminosidade (folhas de sol) apresentam espessura de lâmina foliar $39 \%$ 
maior que as folhas de sombra (baixa luminosidade). Isto ocorre, principalmente, devido ao aumento do parênquima paliçádico cerca de 2.3x (Evans, 1999 apud Mendes et al., 2001). Segundo o autor, o parênquima paliçádico permite uma melhor penetração da luz nos cloroplastos. Desta forma acredita-se que as folhas de sol, exibindo o parênquima paliçádico bem desenvolvido, apresentem uma eficiente estrutura em termos de fotossíntese.

Outro fator ambiental que pode estar relacionado com estas desigualdades estruturais do mesofilo pode ser em relação aos diferentes habitats, especialmente no que diz respeito à disponibilidade de água.

Plantas de ambiente seco (xerófitas) apresentam parênquima paliçádico mais desenvolvido do que o esponjoso, ou então a ocorrência só de paliçádico e pequenos espaços intercelulares (Esau, 1974). O mesofilo isobilateral, apresentando parênquima paliçádico em ambas as faces da folha, é um caráter fortemente xeromorfo (Esau, 1974). Já, as folhas hidromorfas apresentam como caracter comum grandes espaços intercelulares e as folhas mesófitas apresentam combinações de caracteres destes dois ambientes.

Além de todos estes fatores externos, essas diferenças anatômicas também podem ser devido a existência de variedades de Caesalpinia ferrea, conhecidas por $C$. ferrea Mart. ex Tul. var. ferrea e C. ferrea ex Tul. var. leiostachya Benth (Lorenzi, 1992), todavia nos trabalhos científicos as variedades não são diferenciadas. Portanto neste trabalho considerou-se a espécie em estudo como $C$. ferrea.

Apesar dos resultados apresentados neste trabalho quanto às características macro e microscópicas de caule e folhas de Caesalpinia ferrea Mart., ainda devem ser realizados estudos complementares dos processos indiretos (caracterização química, através de cromatografia e reações de identificação de grupos de princípios ativos) dessa espécie, visto que é de fundamental importância a correta identificação da droga vegetal, principalmente de espécies muito utilizadas pela população, como é o caso do pau-ferro. 
Além dos estudos voltados à determinação de eficácia e segurança de uso para produtos fitoterápicos comercializados, a deterrninação de padrão de extrato e de métodos de controle de qualidade deste padrão são exigidos por lei. Além da garantia da identidade botânica e coleta criteriosa, pode-se estabelecer um controle da matéria-prima vegetal por perfil cromatográfico (Figuras 13 e 14) e análise química qualitativa (testes fitoquímicos-Tabela 2).

No perfil cromatográfico de caule de $C$. ferrea pode-se observar na Figura 13 (marcado com retângulo) a presença de um composto químico no extrato bruto liofilizado e em todas as suas frações, o que pode servir como um marcador deste órgão vegetal. Já, no da folha nota-se que há um composto químico, no extrato bruto e nas frações, de mesmo Rf e coloração do padrão utilizado, ácido gálico, o que pode possivelmente sugerir que este padrão sirva como marcador deste órgão vegetal (Figura 14). Além disso, as análises dos cromatogramas no UV $(365 \mathrm{~nm})$ apresentaram manchas vermelhas sugerindo a presença de clorofilas, amarelas que poderiam sugerir a presença de flavonóides e xantonas e outras manchas de azul claro (triterpenos e/ou saponinas) (Wagner et al., 1996). Já na análise fitoquímica das drogas e dos extratos brutos liofilizados da espécie tanto nas folhas como no caule (Tabela 2), observa-se que os grupos químicos majoritários detectados em ambos os órgãos vegetais por tal metodologia foram flavonóides e taninos. Todos estes compostos são responsáveis por inúmeras atividades farmacológicas, dentre elas a atividade antiulcerogênica (Lewis e Hanson, 1991; Martin-Calero et al., 1996; Martin et al., 1998; Carvalho et al., 1999; Santos e Mello, 1999; Harborne e Williams, 2000; Lewis e Shaw, 2001; Schenkel et al., 2003b). Além destes, a droga e o extrato bruto liofilizado de folhas (EBLF) apresentam saponinas, cumarinas e antraderivados.

Os antraderivados destacam-se, principalmente, por sua ação laxante e seus efeitos adversos, tais como o escurecimento da mucosa do reto e cólon durante o consumo abusivo dos fitoterápicos contendo este grupo de princípios ativos, além de alterações morfológicas, processos inflamatórios e degenerativos (Falkenberg, 1999). No ensaio biológico de toxicidade aguda de dose única, 5000 $\mathrm{mg} / \mathrm{kg}$, v.o., alguns destes efeitos puderam ser observados nos animais machos $e$ 
fêmeas que receberam o EBLF, pois 2 machos e 1 fêmea, que morreram ao longo do experimento, apresentaram na porção final do intestino um escurecimento da mucosa, bem como sangue e fezes de consistência alterada (líquida) no seu interior.

Além destes efeitos, os animais machos apresentaram respiração ofegante, hiperexcitabilidade, aumento na reação de susto, redução do reflexo de endireitamento até parada cárdio-respiratória, e as fêmeas manifestaram apenas alteração na freqüência respiratória, ocorrendo a morte de 3 animais machos e 2 fêmeas. Estes animais foram necropsiados e as alterações morfológicas registradas foram pulmão, fígado e rins de coloração alterada com pontos escuros nos 3 animais machos e em uma das fêmeas, em outra, apenas o pulmão apresentou modificação de cor. Não foi observada diferença significativa entre a relação peso órgão/animal deste grupo tratado com o grupo controle de ambos os sexos (Figura 17). Já as fêmeas e os machos deste grupo experimental, apresentaram de maneira geral comportamento semelhante ao grupo controle no consumo de água e ração ao longo de todo o ensaio biológico (Figuras 15 e 16).

Resultados semelhantes também puderam ser observados em camundongos, no ensaio biológico de $\mathrm{DL}_{50}, 1.538-10.080 \mathrm{mg} / \mathrm{kg}$, v.o. (Tabela 5), do extrato bruto liofilizado de folhas (EBLF), como pulmão, fígado e pâncreas com coloração alterada com pontos escuros e estômago e porção do intestino delgado com sangue internamente (possivelmente devido à presença de antraderivados neste extrato vegetal, como já foi discutido anteriormente), e hemorragia pelo nariz, em ambos os sexos nas doses de 3.938 e $6.300 \mathrm{mg} / \mathrm{Kg}$. Dentre estas variações, vale ressaltar a hemorragia interna apresentada pelos animais que vieram a óbito.

Este resultado, junto aos da triagem fitoquímica qualitativa (Tabela 2) levanos a sugerir que tal efeito é devido à presença de cumarina neste extrato vegetal. Atualmente, as cumarinas além de um grande potencial terapêutico como anticoagulantes, destacam-se clinicamente no tratamento de linfedema (Born et al., 1998), bruceloses, infecções crônicas (Egan et al., 1990; Fentem et al., 1992) e cânceres humanos (Egan et al., 1990; Fentem et al., 1992; Born et al.; 1998). 
Porém, nos arimais de laboratório, em especial nos roedores, este grupo químico não apresenta nenhuma atividade farmacológica, mas uma peculiar toxicidade hepática ou pulmonar (Lake et al., 1989; Egan et al., 1990; Born et al.; 1998), que leva a uma intensa hemorragia interna e conseqüentemente à morte do animal (Fracasso e Larini, 1987).

Já, os animais que receberam o extrato bruto liofilizado de caule de $C$. ferrea, dose única, 5000 mg/kg, v.o., na toxicidade aguda, não apresentaram nenhuma alteração comportamental, exceto um animal macho que exibiu uma diminuição na atividade motora, bem como respiração ofegante até parada cárdiorespiratória, 96 horas após a administração do extrato. Este animal foi autopsiado e as alterações morfológicas registradas foram semelhantes às já citadas anteriormente. Diante destes resultados apresentados, não foi realizado a $D L_{50}$ deste extrato vegetal.

Os animais, machos e fêmeas deste grupo experimental, também não apresentaram nenhuma diferença significativa na relação peso órgão/animal em comparação ao grupo controle (Figura 17). Na ingestão de água, as fêmeas apresentaram consumo semelhante ao grupo controle, enquanto que os machos mostraram uma diminuição bastante evidente ao longo dos 14 dias de observação do teste de toxicidade aguda (Figura 15). Quanto ao consumo de ração, ambos os sexos apresentaram um aumento por volta do $5^{\circ}$ dia de observação, que decaiu pelo $13^{\circ}$ dia em relação ao grupo controle (Figura 16 ).

Frente a todos estes resultados, estudou-se a toxicidade subcrônica de ambos os extratos brutos liofilizados, caule e folha, nas doses de $400 \mathrm{mg} / \mathrm{kg}$ e $800 \mathrm{mg} / \mathrm{kg}$, v.o., durante 33 dias. Ao longo do tratamento, foram determinados a cada 2 dias, o peso corporal de cada arimal e o consumo de água e ração.

Alguns resultados já descritos nos experimentos de toxicidade aguda, como fígado com pontos escuros puderam ser observados em machos e fêmeas de ambas as doses dos dois extratos vegetais. Além disso, 1 animal macho e 1 fêmea, que receberam extrato bruto liofilizado de folha (EBLF) ou de caule (EBLC) de $C$. ferrea, na dose de $800 \mathrm{mg} / \mathrm{kg}$, v.o., mostraram alteração na coloração do 
pulmão (pontos escuros (EBLF) ou avermelhado (EBLC)). Porém, não foi observada diferença significativa entre a relação peso órgão/animal (fígado e coração/pulmão) dos animais fêmeas e machos que receberam 400 ou $800 \mathrm{mg} / \mathrm{kg}$ de EBLC ou EBLF em relação ao controle (Figuras 20 e 21), exceto uma diferença significativa $(p<0.05)$ em relação ao rim dos animais fêmeas do EBLC na maior dose.

As fêmeas e os machos que receberam EBLF-400 mg/kg ou $800 \mathrm{mg} / \mathrm{kg}$, não apresentaram diferença no consumo de água em relação ao grupo controle ao longo de todo o ensaio (Figura 18). Já, na ingesta de ração, os machos, de ambas as doses, exibiram um menor consumo durante os 33 dias de experimento (Figura 19). Entretanto, os animais machos que receberam EBLC, na dose de $800 \mathrm{mg} / \mathrm{kg}$, apresentaram um pequeno aumento do consumo de água durante o ensaio (Figura 18). Já, os animais fêmeas e machos que receberam este mesmo extrato vegetal, em ambas as doses, não mostraram diferença no consumo de ração em relação ao grupo controle ao longo dos 33 dias de experimento (Figura 18 e 19).

Quanto à determinação dos parâmetros bioquímicos e hematológicos, os grupos tratados (EBLF e EBLC) apresentaram, de uma maneira geral, resultados semelhantes ao grupo controle (Tabelas 6 e 7). Além disso, estes dados hematológicos vão ao encontro dos propostos por Matsuda et al. (2000) onde os autores indicam os intervalos de normalidade de alguns dos parâmetros sangüíneos de ratos como, por exemplo, proteína total $(\mathrm{g} / \mathrm{dL}): 5.9-8.4$; glicose $(\mathrm{mg} / \mathrm{dL}): 89.5-183.3$ e colesterol total $(\mathrm{mg} / \mathrm{dL}): 50-100$.

Di Stasi e Hiruma-Lima (Di Stasi, Hiruma-Lima et al., 2002), em pesquisa bibliográfica sobre a espécie vegetal, verificaram que foram realizados ensaios de toxicidade, apresentados em Congressos da Área. Apesar de nossos dados estarem de acordo com os encontrados na literatura, novos experimentos de toxicidade aguda, subcrônica e crônica devem ser realizados com outros animais experimentais (mamíferos, não-roedores) para que se possa determinar realmente a toxicidade deste vegetal à espécie humana, já que há uma significativa 
diferença interespecífica no metabolismo, em especial das cumarinas, entre o homem e os roedores.

Considerando-se ainda os objetivos deste trabalho, realizamos o teste de atividade antiulcerogênica aguda e subcrônica de ambos os extratos vegetais, propriedade pela qual a espécie é muito utilizada pela medicina tradicional.

A úlcera gástrica, induzida pelo etanol ou pelo etanol acidificado, ocorre devido à redução do fluxo sangïíneo na mucosa gástrica seguida de estase sangüínea, que contribui para o desenvolvimento de hemorragias e necrose de tecidos (Guth et al., 1984), causando também redução dos níveis de compostos sulfidrílicos, agentes capazes de se ligarem a radicais livres ativos, gerando injúria tecidual (Crawford, 1994; Sartori, 1997; Rang e Dale, 2001). Todos estes efeitos são observados em maior nível de severidade com a utilização da solução etanol/HCl como agente irritante, em comparação com o etanol isoladamente.

Por outro lado, as ulcerações gástricas induzidas por etanol causam danos diretos sobre as células da mucosa gástrica, resultando no desenvolvimento dos radicais livres e peroxidação de lipídios (Puurunen et al., 1981; Glavin e Szabo, 1992). Muitos trabalhos têm demonstrado que os radicais livres derivados de oxigênio estão diretamente relacionados às lesões provocadas pelo etanol e pela associação deste com o $\mathrm{HCl}$, o qual acarreta injúria isquêmica no estômago (Szabo e Vattay, 1990; Sartori, 1997), levando, desta forma, a hipóxia e conseqüentemente ao aumento da concentração de íons superóxido (Kvietys et al., 1990; Salim, 1990).

Uma revisão realizada por Lewis e Hanson (1991) mostrou que dentre os inúmeros compostos secundários presentes no reino vegetal, os triterpenos, os alcalóides e os flavonóides destacam-se por apresentar atividade antiulcerogênica em diferentes modelos experimentais como indometacina, etanol, ligadura de piloro, estresse, e antioxidante entre outros. Dentre estes compostos, os flavonóides, presentes em ambos os extratos vegetais (Tabela 2), apresentam inúmeras propriedades farmacológicas no trato gastrintestinal, como antiinflamatória (Sánchez de Medina et al., 1996; Ocete et al., 1998; Crespo et al., 
1999), protetora de mucosa de colite em ratos (Gálvez et al., 1997), antioxidante (Yuting et al., 1990; Suzuki et al., 1998; Kahraman et al., 2003), seqüestrante de radicais livres (Yuting et al., 1990; Harborne e Williams, 2000; Borrelli e Izzo, 2000) e antiulcerogênica (Di Carlo et al., 1999; La Casa et al., 2000). Uma revisão realizada por La Casa et al. (2000) mostra que estes compostos secundários são bons agentes antiinflamatórios e também capazes de proteger a mucosa gástrica contra inúmeros fatores ulcerogênicos. Tais ações ocorrem via inúmeros mecanismos de ação dos quais pode-se destacar a ação seqüestrante de radicais livres (Yuting et al., 1990; La Casa et al., 2000), conduzindo a atividade antioxidante. Os radicais livres $\left(\mathrm{O}_{2}{ }^{\circ}, \mathbf{O H}^{\circ}\right)$ têm uma importante função na formação das lesões ulcerativas e erosivas do trato gastrintestinal, por atacarem constituintes celulares essenciais (proteínas, lipídios, ácidos nucléicos) e também induzirem a peroxidação lipídica dos ácidos graxos das membranas celulares levando à formação de compostos tóxicos (Kahraman et al., 2003).

Além dos flavonóides, outros compostos fenólicos, também presentes em ambos os extratos brutos liofizados, vêm recebendo destaque na terapia antiulcerogênica, os taninos (Tabela 2). Este grupo químico têm apresentado inúmeras atividades biológicas e farmacológicas das quais se destacam a ação bactericida e anti-helmíntica, anti-hepatotóxica, inibição da replicação do HIV e, principalmente, complexação com macromolécula (proteínas e polissacarídeos), ação antioxidante e seqüestrante de radicais livres (Haslam, 1996).

Os resultados obtidos com os extratos brutos liofilizados de folhas e caule de $C$. ferrea no modelo de úlcera gástrica induzida por etanol $/ \mathrm{HCl}$ pode ser observado na Figura 22. A dose de $400 \mathrm{mg} / \mathrm{kg}$ (v.o) do extrato de caule reduziu em $37 \%$ a Área Relativa de Lesão (ARL). Já o extrato de folhas foi tão ativo como o Misoprostol reduzindo em 95\%, 81\% e 63\% a Área Total de Lesão (ATL), a Área Relativa de Lesão (ARL) e o Índice de Lesão Ulcerativa (ILU), respectivamente contra $92 \%, 70 \%$ e $59 \%$ do fármaco de referência.

Frente a estes dados de potente atividade antiulcerogênica apresentada por ambos os extratos brutos liofilizados vegetais, utilizou-se o modelo de indução 
gástrica subcrônica por ácido acético 30\%, devido à semelhança macro e microscópica à úlcera humana.

Os grupos tratados, de ambos os extratos brutos liofilizados deste experimento, não apresentaram diferença significativa com o grupo controle (Figuras 26 e 27).

Os resultados obtidos do EBLC e EBLF de $C$. ferrea foram bastante significativos no ensaio de lipoperoxidação de homogenato de cérebro de rato (Tabela 8 e 9, Figuras 28 e 29). Estes extratos apresentaram uma atividade antioxidante de $93,56 \%$ (folhas) e $84,38 \%$ (caule) na concentração de $0,05 \mathrm{mg} / \mathrm{mL}$ e um $Q_{1 / 2}$ de $0,2331 \mu \mathrm{g} / \mathrm{mL}$ e $0,5061 \mu \mathrm{g} / \mathrm{mL}$, respectivamente (Tabela 8 e 9), contra um $\mathrm{Q}_{1 / 2}$ de $38,5 \mu \mathrm{g} / \mathrm{mL}$ e $19,3 \mu \mathrm{g} / \mathrm{mL}$ dos extratos etanólicos $50 \%$ destes mesmos órgãos vegetais de Pothomophe umbellata (Barros et al., 1996).

Diante de todo este contexto e da significativa atividade antioxidante apresentada pelos EBLF e EBLC, realizou-se o ensaio de úlcera gástrica aguda induzida por etanol/HCl com as frações dos extratos brutos liofilizados (clorofórmica, acetato de etila, etanólica 100\% e etanólica 50\%) e frações enriquecidas em flavonóides. Os grupos tratados com as frações de ambos os extratos ou os extratos enriquecidos, neste modelo farmacológico, não apresentaram diferença significativa em relação ao grupo controle (Figuras 23-25).

Diante de todos estes resultados, a compreensão do mecarismo de ação da atividade antiulcerogênica desta espécie requer a realização de outro modelos experimentais de ulceração, no entanto pode-se descartar inicialmente uma possível ação trófica da gastrina, como por exemplo, a estimulação da proliferação das células da mucosa gástrica (Ishihara e Ito, 2002), já que os extratos não apresentaram atividade antiulcerogênica no modelo de úlcera subcrônica. Porém, pode-se sugerir uma ação sinérgica entre alguns grupos químicos dos extratos brutos liofilizados de caule e folhas de $C$. ferrea, visto que o fracionamento destes levou à anulação do efeito protetor de mucosa gástrica.

Desta forma, estes dados juntamente àqueles da triagem fitoquímica qualitativa (Tabela 2) sugerem que os flavonóides e os taninos possam ser os 
possíveis princípios ativos de ambos os extratos vegetais. Os taninos, por se complexarem com proteínas, podem vir a formar uma camada protetora sobre a mucosa gástrica, e os flavonóides, sendo potentes compostos antioxidantes, são capazes de inibir a peroxidação lipídica e também, de inativar os íons superóxido (Haslam, 1996; Arts et al., 2001), produzindo assim um significativo efeito antiulcerogênico, confirmando o uso popular da espécie estudada.

Já, no ensaio de atividade cicatrizante da espécie em estudo, observou-se que a partir do $2^{0}$ dia após a incisão, os animais dos grupos tratados (extratos brutos liofilizados de folhas e caule) já apresentaram uma formação de crosta mais significativa que aqueles do grupo controle. Todavia, evidenciou-se o fechamento das feridas, primeiramente nos animais que receberam água topicamente (Figura 30).

Apesar desta espécie ser utilizada pela população como cicatrizante, também não foi possivel confirmar tal uso, para ambos os órgãos vegetais, folha e caule, no laudo histopatológico (Figuras 31-39). 


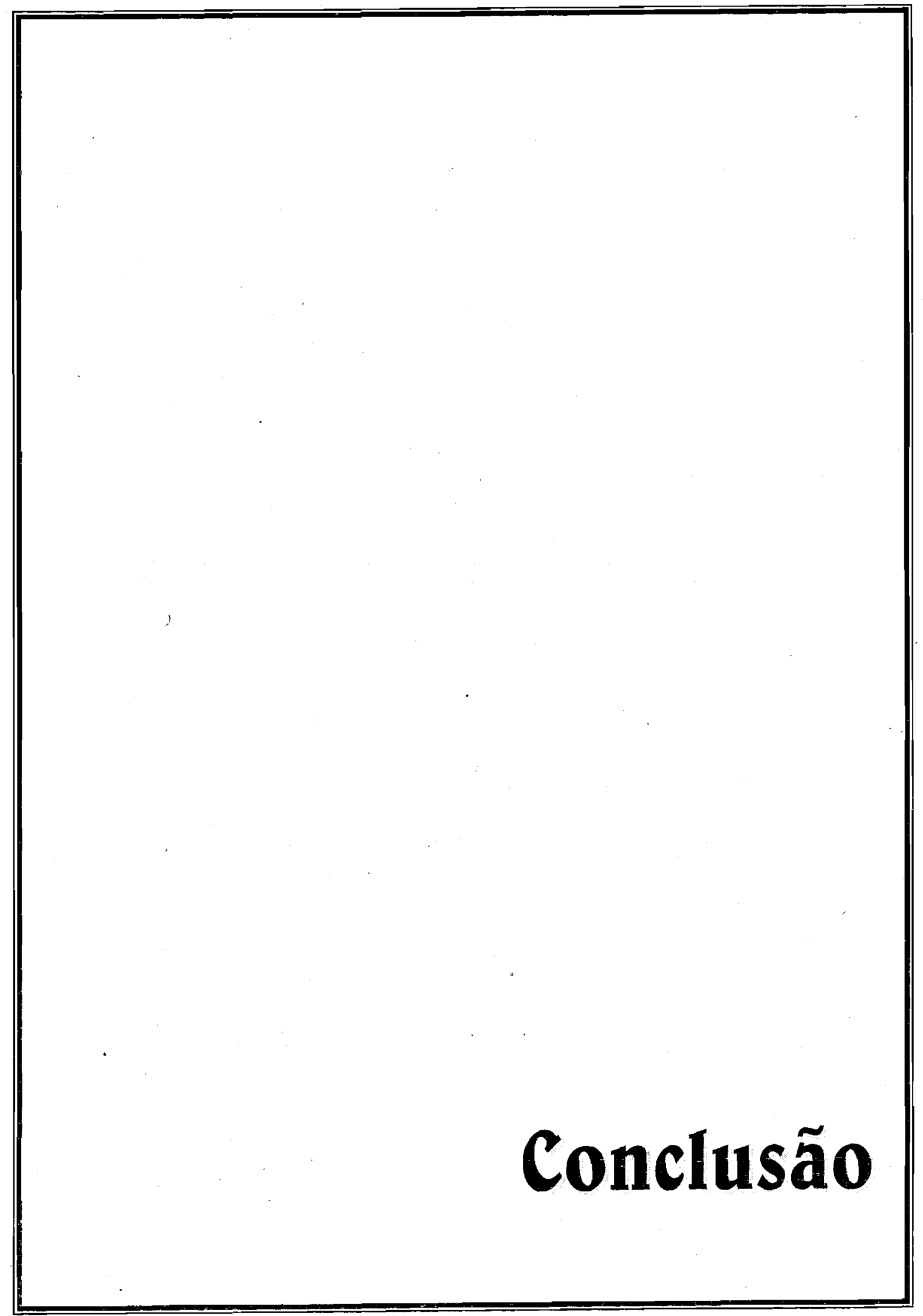




\section{Conclusões}

A droga vegetal constituída de folha de $C$. ferrea apresentou folíolos sésseis, de base inequielátera, verde opalescente nas 2 faces. Já a droga vegetal de caule da mesma espécie vegetal, apresenta superfície externa de coloração marrom com freqüentes lenticelas de forma lenticular (caule de menor diâmetro1-2 cm) ou tronco cinéreo acrescido de manchas esbranquiçadas alongadas longitudinalmente.

As características anatômicas observadas foram:

- Na folha: mesofilo constituído de 4 a 5 camadas de parênquima paliçádico; tricomas glandulares pluricelulares na face abaxial; feixes vasculares de menor calibre apresentam bainha cristalífera, calota fibrosa conspícua externamente à região floemática.

- No Caule: no caule com cerca de 1-2 mm de diâmetro, o súber é constituído por células espessadas, suberizadas; a feloderme é constituída de até 10 camadas de células espessadas de paredes celulósicas, observando-se grande número de drusas e cristais prismáticos; externamente à região floemática, encontra-se anel esclerenquimático contínuo, constituído, predominantemente de fibras, intercaladas com esclereídes; no floema observa-se freqüentemente drusas e raros cristais prismáticos e no xilema parênquima axial em faixas tangenciais descontínuas irregularmente espaçadas e arranjo paratraqueal escasso a vasicêntrico, já em caules de diâmetro maior (2mm) há predominância do parênquima em faixas contínuas.

Os principais constituintes químicos presentes em ambos os órgãos vegetais da espécie foram flavonóides e taninos, além de saponinas, cumarinas e antraderivados nas folhas. O teor de taninos na droga vegetal de folha foi de $7,13 \%$ e caule $2,26 \%$, já no extrato bruto liofilizado foi de $23,95 \%$ e $11,77 \%$, respectivamente. O pó da droga vegetal de folha apresentou $0,0095 \%$ de 
flavonóides totais e 0,026 no EBLF, enquanto que o caule, 0,00014\% no pó da droga e $0,0017 \%$ no EBLC.

O perfil cromatográfico dos extratos vegetais foi determinado em comparação com o ácido clorogênico, naringenina e ácido cafeico como padrões no caule, e ácido gálico na folha.

Os dados da avaliação toxicológica mostram que o EBLC apresentou baixa toxicidade, e que o EBLF merece novos experimentos para que se possa determinar realmente a toxicidade deste órgão vegetal, já que há uma significativa diferença interespecífica no metabolismo, em especial das cumarinas, entre o homem e os roedores;

Os resultados permitem atribuir atividade antiulcerogênica dos EBLF e EBLC da espécie vegetal em estudo, na dose de $400 \mathrm{mg} / \mathrm{kg}$, v.o., no modelo de indução de úlcera aguda por etanol acidificado em ratos.

Pode-se sugerir inicialmente uma ação sinérgica entre flavonóides e taninos quanto à atividade antiulcerogênica aguda dos EBLF e EBLC.

OS EBLF e EBLC indicam excelente atividade antioxidante, através da medida da produção de malonildialdeido na lipoperoxidação espontânea de homogeneizado de cérebro de ratos, comparado a outros extratos, avaliados através do mesmo método.

Os resultados não permitem atribuir atividade cicatrizante dos EBLF e EBLC da espécie vegetal em estudo, através do ensaio realizado, na dosagem de 15\% em água, via tópica. 


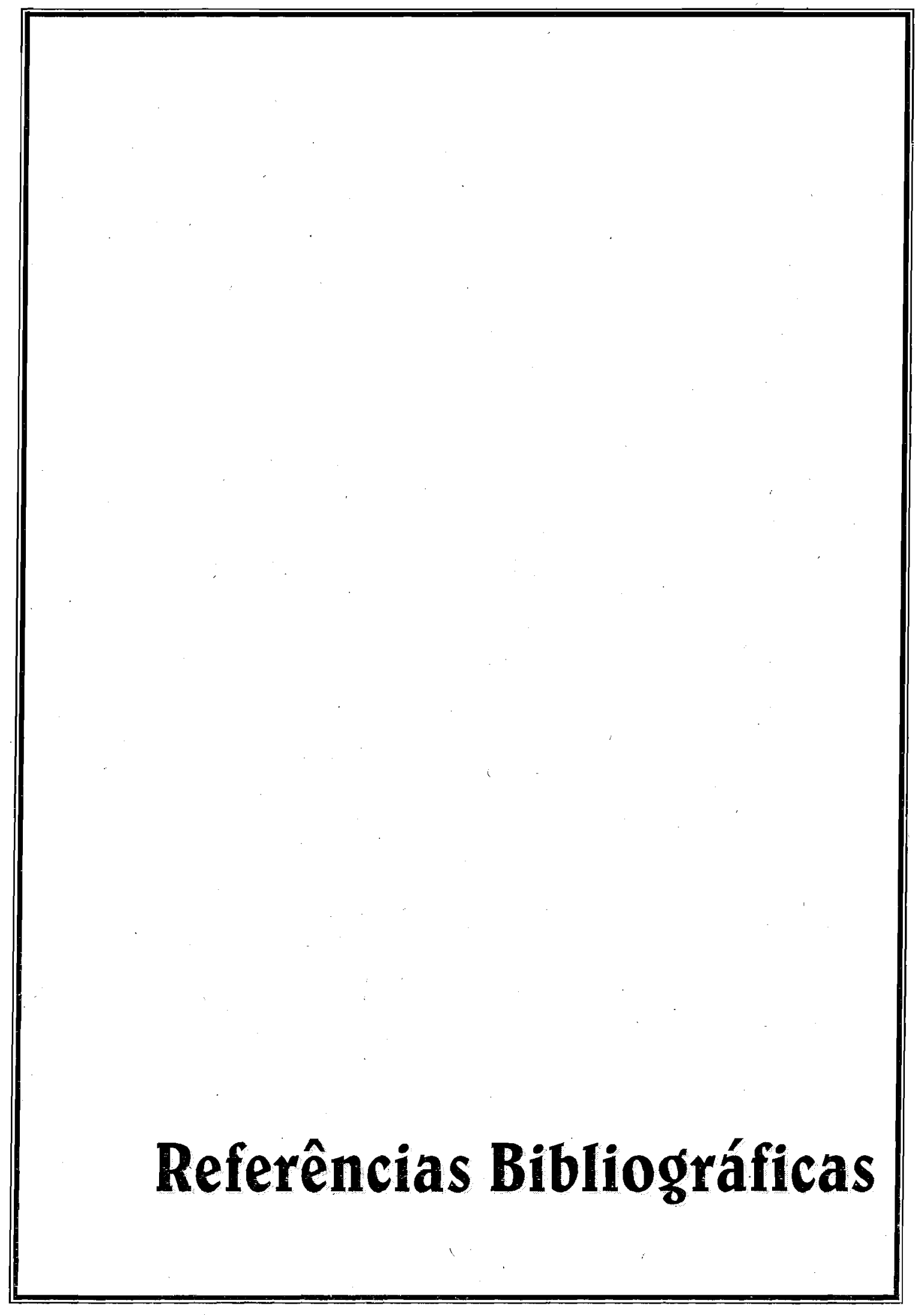




\section{Referências Bibliográficas}

A GUERRA dos remédios. Folha de São Paulo, São Paulo, 17 fev. 1997.

ALPER, J. Ulcers as an infectious diseases. Science, Washington, v.260, n.9, p.159-160, 1993.

ARTS, M.J.T.J.; HAENEN, G.R.M.M.; VOSS, H.P.; BAST, A. Masking of antioxidant capacity by the interaction of flavonoids with protein. Food Chem. Toxicol., Amsterdam, v.39, n.8, p.787-791, 2001.

BACCHI, E.M.; SERTIE, J.A.A.; VILLA, N.; KATZ, H. Antiulcer action and toxicity of Styrax camporum e Caesalpinia ferrea. Planta Med., Stuttgart, v.61, n.3, p.204-207, 1995.

BANSKOTA, A.H.; ATTAMIMI, F.; USIA, T.; LINN, T.Z.; TEZUKA, Y.; KALAUNIA, S.K.; KADOTA, S. Novel norcassane-type diterpene from the seed kernels of Caesalpinia crista. Tetrahedron Lett., Amsterdam, v.44, n.36, p.6879-6882, 2003.

BARROS, S.B.M., TEIXEIRA, D.S., AZNAR, A.E., MOREIRA, J.A.J., ISHII,I., FREITAS, PC.D. Antioxidant activity of ethanolic extracts of Pothomorphe umbellata L. Miq. (Pariparoba). Free Radical Res. Latim America, v.48, n.1/2, p.114-116, 1996.

BERLYN, G.P.; MIKSCHE, J.P. Botanical microtechnique and cytochemistry. Ames: lowa State Universty Press, 1976.

BISKY, F.A., BUOKINGHAM, J, HARBORNE, J.B. Phytochemistry Dictionary of the Leguminosae. v.1,1 ${ }^{a}$ Edição, Reino Unido: Editora Chapman \& Hall, 1994, 131-137.

BORN, S.L.; FIX, A.S.; CAUDILL, D.; LEHMAN-MCKEEMAN, L.D. Selective Clara cell injury in mouse lung following acute admiristration of coumarin. Toxicol. Appl. Pharmacol., New York, v.151, n.1, p.45-56, 1998.

BORRELLI, F.; IZZO, A.A. The plant kingdom as a source of anti-ulcer remedies. Phytother. Res., Bognor Regis, v.14, p.581-591, 2000.

BRITO, A.S. Manual de ensaios toxicológicos "in vivo": ciências médicas. Campinas: Unicamp, 1994. p.15-22. 
CARVALHO, J.C.T.; TEIXEIRA, J.R.M.; SOUZA, P.J.C.; BASTOS, J.K.; DOSSANTOS, D.; SARTI, S.J. Preliminary studies of analgesic and antiinflammatory properties of Caesalpinia ferrea crude extract. J. Ethnopharmacol., Amsterdam, v.53, n.3, p.175-178, 1996.

CARVALHO, J.C.,GOSMANN, G., SCHENKEL, E.P. Compostos fenólicos simples e heterosideos. In: SIMÕES, C.M.O.; SCHENKEL, E.P.; GOSMANN, G.; MELLO, J.C.P.; MENTZ, L.A.; PETROVICK, P.R., orgs. Farmacognosia: da planta ao medicamento. Florianópolis: UFSC, Porto Alegre: UFSC, 1999. p.433-450.

COELHO, R.G. Estudo Químico de Zollernia ilicifolia (Fabaceae), Wilbrandia ebracteata (Cucurbitaceae) e Caesalpinia ferrea (Caesalpiniaceae). 2004.181p. Tese (Doutorado em Química)- Instituto de Química, Universiddual Paulista "Júlio de Mesquita Filho", Araraquara, 2004.

CORREA, M.P. Dicionário das plantas úteis do Brasil e das exóticas cultivadas. Rio de Janeiro: IBDF, 1984. v.6, p.170-177.

CRAWFORD, J.M. Trato gastrointestinal. In: COTRAN, R.S.; KUMAR, V.; ROBBINS, S.L., eds. Robbins patologia estrutural e funcional. 5.ed. Rio de Janeiro: Guanabara Koogan, 1994. cap.17, p.672-742.

CRESPO, M.E.; GALVEZ, J.; CRUZ, T.; OCETE, M.A.; ZARZUELO, A. Antiinflammatory activity of diosmin and hesperidin in rat colitis induced by TNBS. Planta Med., Stuttgart, v.65, n.7, p.651-653, 1999.

CURTIS, J.D. et al. Leaf anatomy emphasizing unusual "concertina" mesophyll cells, of two east African legumes (Caesalpinieae, Caesalpirioideae, Leguminosae). Annals of Botany, Oxford, 8: 55-59, 1996.

DI CARLO, G.; MASCOLO, N.; IZZO, A.A.; CAPASSO, F. Flavonoids: old and new aspects of a class of natural therapeutic drugs. Life Sci., Amsterdam, v.65, n.4, p.337-353, 1999. [Review].

DI STASI, L.C.; HIRUMA LIMA, C.A., GONZALEZ, F.G., SEITO, L.N.,MARIOT, A.,BRITO, A.R.M.S., Plantas medicinais na Amazônia e na Mata Atlântica. 2.ed. São Paulo: UNESP, 2002. 607p. 
EGAN, D.; OKENNEDY, R.; MORAN, E.; COX, D.; PROSSER, E.; THORNES, R.D. The pharmacology, metabolism, analysis and applications of coumarin and coumarin- related compounds. Drug Metab. Rev., Monticello, v.22, n.5, p.503-529, 1990. [Review].

ESAU, K. Anatomia das plantas com sementes. São Paulo, Edgar Blüncher, 294p., 1974.

EUROPEAN Pharmacopoeia: supplement 2001. $3^{\underline{a}}$ ed. Strasbourg: Concil of Europe, 2001. 1705p.

FALKENBERG, M.B. Quinonas. In: SIMÕES, C.M.O.; SCHENKEL, E.P.; GOSMANN, G.; MELLO, J.C.P.; MENTZ, L.A.; PETROVICK, P.R., eds. Farmacognosia: da planta ao medicamento. Porto Alegre: UFSC; Porto Alegre: UFRGS, 1999. p.545-570.

FARMACOPÉIA BRASILEIRA, 4ª EDIÇÃO-DOU DE 20/06/2003, Fasciculo 4, parte ii, monografia 182.

FARMACOPÉIA Brasileira. 4.ed. São Paulo: Atheneu, 1988. pt.1.

FARNSWORTH, N.R. Biological and phytochemical screening of plants. J. Pharm. Sci., Hoboken, v.55, n.3, p.225-276, 1966.

FAUST, T.A. Caesalpinia digyna. J. Am. Leather Chem. Assoc., Lubbock, v.8, p.154-158, 1913.

FEE, J.A. \& TEITELBAUM, H.D. Evidence that superoxide dismutase plays a role in protecting red blood cells against peroxidative hemolysis. Biochem. Biophys. Res. Commun., Orlando, v.49, p.150-158, 1972.

FENTEM, J.H.; FRY, J.R.; THOMAS, N.W. Species differences in the hepatotoxicity of coumarin: a comparison of rat and Mongolian gerbil. Toxicology, Amsterdam, v.71, n.1/2, p.129-136, 1992.

FRACASSO, J.F. e LARINI, L. Rodenticidas Anticoagulantes. In: LARINI, L. Toxicologia. 2.ed. São Paulo: Manole, 1987. p.210-216.

FRANKLIN, G.L. Preparation of thin sections of synthetic resins and wood-resin composites, and a new macerating method for wood. Nature, London, v.155, n.3924, p.51, 1945. [Letter]. 
GALI-MUHTASIB, H.U.; YANUT, S. Inhibition of hydroperoxide production and tumor promotion by hydrolyzable and condensed tannins in mouse skin treated with ultraviolet B radiation. Lebanese Abstract III, 417, 1997.

GÁlVEZ, J.; CRUZ, T.; CRESPO, E.; OCETE, M.A.; LORENTE, M.D.; DE MEDINA, F.S.; ZARZUELO, A. Rutoside as mucosal protective in acetic acidinduced rat colitis. Planta Med., Stuttgart, v.63, n.5, p.409-414, 1997.

GARCIA-BARRIGA, H. Flora medicinal de Colômbia: botânica médica. Bogota: Universidade Nacional, 1974. v.1, p.442-443.

GARRO GALVES, J.M.; RIEDL, B.; CONNER, A.H. Analytical studies on tara tannins. Holzforschung, Berlin, v.51, n.3, p.235-243, 1997.

GIBBS, R.D. Chemotaxonomy of flowering plants. Montreal: McGill-Queen's University Press, 1974. v.3, p.1629-1641.

GLAVIN, B. \& SZABO, S. Experimental gastric mucosal injury: laboratory models reveal mechanisms of pathogenesis and new therapeutic strategies. FASEB J., Bethesda, v.6, p.825-831, 1992.

GONZALEZ, F.G., PORTELA, T.Y., STIPP, E.J. DI STASI, L.C. Antiulcerogenic and analgesic effects of Maytenus aquifolium, Sorocea bomplandii and Zolernia ilicifolia. J. Ethnopharmacol., Amsterdam, v.77, p.41-47, 2001.

GUTH, P.H.; PAULSEN, G.; NAGATA, H. Histologic and microcirculatory changes in alcohol- induced gastric lesions in the rat: effect of prostaglandin cytoprotection. Gastroenterology, Orlando, v.87, n.5, p.1083-1090, 1984.

HAMILTON, M.A.; RUSSO, R.C.; THURSTON, R.V. Trimmed Spearman-Karber method for estimating median lethal concentrations in toxicity bioassays. Environ. Sci. Technol., Columbus, v.11, n.7, p.714-718, 1977.

HARBORNE, J.B.; WILLIAMS, C.A. Advances in flavonoids research since 1992. Phytochemistry, New York, v.55, p.481-504, 2000.

HASLAM, E. Natural polyphenols (vegetable tannins) as drugs and medicines: possible modes of action. J. Nat. Prod., Columbus, v.59, p.205-215, 1996. HUTCHINSON, J.L.L.D. The genera of flowering plants. Oxford University Press, London, 1964, p. 221-233. 
HUTCHINSON, J.L.L.D. Evolution and Phylogeny of flowering plants. Academic Press, London, 1969, p. 294-297.

ISHIHARA, I. \& ITO, M. Influence of aging on gastric ulcer healing activities of cimetidine and omeprazole. Eur. J. Pharmacol., Amsterdam, v.444, p.209215, 2002.

JAROSZEWSKI, J.W. Natural products and drug development. Pharm. Int., Amsterdam, v.5, p.27-28, 1984.

JOHANSEN, D.A. Plant microtechnique. New York: Mcgraw-Hill, 1940. 523p.

JOLY, A.B. Botânica: introdução a taxonomia vegetal. São Paulo: Nacional, 1966. p.371-378. (Biblioteca Universitária. Série 3.a. Ciências Puras, v.4).

JUNQUEIRA, L.C.; BIGNOLAS, G.; BRENTANI, R.E. Picrosirius staining plus polarization microscopy- a specific method for collagen detection in tissue section. Histochemical Journal, v.11, p.447-55, 1979.

KAHRAMAN, A.; ERKASAP, N.; KOKEN, T.; SERTESER, M.; AKTEPE, F.; ERKASAP, S. The antioxidative and antihistaminic properties of quercetin in ethanol-induced gastric lesions. Toxicology, Amsterdam, v.183, n.1/3, p.133$142,2003$.

KIM, Y. et al. Inhibitory effects of herbal medicines an hyaluronidase activity. Saengyak Hakhoechi, Seoul, v.36, n.3, p.265-272, 1995.

KITAGAWA, K.A.M., DE COSTER, S.; MURIUKI, G.; MASENGO, W.; KIBWAGE, I.; HOOGMARTENS, J.; LAEKEMAN, G.M. Antimalarial activity of Ajuga remota Benth. (Labiatae) and Caesalpinia volkensii Harms (Caesalpiniaceae): in vitro confirmation of ethnopharmacological use. Chem. Pharm. Bull., Amsterdam, v.44, p.11574, 1996.

KURIA, K.A.M., DE COSTER, S.; MURIUKI, G.; MASENGO, W.; KIBWAGE, I.; HOOGMARTENS, J.; LAEKEMAN, G.M. Antimalarial activity of Ajuga remota Benth. (Labiatae) and Caesalpinia volkensii Harms (Caesalpiniaceae): in vitro confirmation of ethnopharmacological use. J. Ethnopharmacol., Amsterdam, v.74, n.2, p.141-148, 2001. 
KVIETYS, P.R.; TWOHIG, B.; DANZELL, J.; SPECIAN, R.D. Ethanol-induced injury to the rat gastric mucosa: role of neutrophil and xantine oxidase-derived radicals. Gastroenterology, Orlando, v.98, n.4, p.909-920, 1990.

LA CASA, C. VILLEGAS, I.; ALARCON DE LA LASTRA, C.; MOTILVA, V.; CALERO, M.J.M. Evidence for protective and antioxidant properties of rutin, a natural flavone, against ethanol induced gastric lesions. J. Ethnopharmacol., Amsterdam, v.71, n.1/2, p.45-53, 2000.

LAKE, B.G.; GRAY, T.J.; EVANS, J.G.; LEWIS, D.F.; BEAMAND, J.A.; HUE, K.L. Studies on the mechanisms of coumarin-induced toxicity in rat hepatocytes: comparison with dihydrocoumarin and other coumarin metabolites. Toxicol. Appl. Pharmacol., New York, v.97, n.2, p.311-323, 1989.

LEWIS, D.A.; HANSON, P.J. Anti-ulcer drugs of plant origin. Prog. Med. Chem., Amsterdam, v.28, p.201-231, 1991.

LEWIS, D.A.; SHAW, G.P. A natural flavonoid and synthetic analogues protect the gastric mucosa from aspirin-unduced erosions. J. Nutr. Biochem., New York, v.12, p.95-100, 2001.

LORENZI, H. Árvores Brasileiras: Manual de identificação e cultivo de plantas arbóreas e nativas do Brasil. Nova Odessa, São Paulo: Editora Plantarum, 1992.

LUNA, G.C. Manual of histologic staining methods of the Armed Forces. Institut of Pathology. 3ed. New York, Mc Graw-Hill, 1968, p.285.

MAHATO, S.B.; SAHU, N.P.; LUGER, P. Structura of caesalpinine A: a novel spermidine alkaloid from Caesalpinia digyna Rottl. J. Am. Chem. Soc., Columbus, v.105, p.4441-4445, 1983.

MARTIN CALERO, M.; LA CASA, C.; MOTILVA, V.; LOPEZ, A.; ALARCON DE LA LASTRA, C. Healing process induced by a flavonic fraction of Bidens aurea on chronic gastric lesion in rat. Role of angiogenesis and neutrophil inhibition. $\mathbf{Z}$. Naturforsch., C: J. Biosci., Tuebingen, v.51, n.7/8, p.570-577, 1996.

MARTIN, M.J. La Casa, C.; Alarcon de La Lastra, C.; Cabeza, J.; Villegas, I.; Motilva, V.; Anti-oxidant mechanisms involved in gastroprotective effects of 
quercetin. Z. Naturforsch., C: J. Biosci., Tuebingen, v.53, n.1/2, p.82-88, 1998.

MATOS, F. J.A. Introdução à fitoquímica experimental. Fortaleza: Universidade do Ceará, 1988. p.126. (Coleção Ciência, 3).

MATSUDA, H., TANAKA, A., ITAKURA, A. Immunology and Hematology. In: Krinke, G.J. The Handbook of Experimental Animals - The laboratory rat. Londres: Academic Press, 2000. p. 437-441.

MCPHERSON, D.D., CORDELL, G.A., SOEJARTO, D.D., PIZZUTO,J.M., FONG, H.H.S. Pelttogynoids and homoflavonoids from Caesalpinia pulcherrima. Phytochemistry, New york, 22: 2835-2838, 1983.

MENDES, M.M. et al. Acclimation of Myrtus communis to constrasting Mediterranean ligth environments-effects on structure and chemical composition of foliage and plant water relations. Environmental and Experimental Botany, Amsterdam, 45 (2): 165-178, April, 2001.

METCALFE, C.R.; CHALK. Anatomy of the dicotyledons. Berlin: Gebruder Borntraeger Nicolasse, 1964. p.476-501.

MIZUI, T. e DOTEUCHI, M. Effect of polyamines on acidified ethanol-induced gastric lesions in rats. Jpn. J. Pharmacol., Tokyo, v.33, p.939-945, 1983.

MUKHERJEE, P.K.; VERPOORTE, R.; SURESH,B. Evaluation of in-vivo wound healing activity of Hypericum patulum (Family: Hypericaceae) leaf extract on different wound model in rats. J. Ethnopharmacol., Amsterdam, v.70, p.315321,2000

MYERS, B.J. et al. Leaf water relations and anatomy of a tropical rainforest tree species vary with crown position. Oecologia, Berlim, 74: 81-85, 1987.

NAGAI, M.; NAGUMO, S. Protosappanin C from sappan lignum and absolute configuration of protosappanins. Chem. Pharm. Bull., Tokyo, v.35, n.7, p.3002-3005, 1987.

NAGAI, M.; NAGUMO, S. Protosappanins $E_{1}$ and $E_{2}$, stereisomeric dibenzoxocins combined with Brazilin from Sappan lignum. Chem. Pharm. Bull., Tokyo, v.38, n.6, p.1490-1494, 1990. 
NAKAMURA, E.S.; KUROSAKI, F.; ARISAWA, M.; MUKAINAKA, T.; TAKAYASU, J.; OKUDA, M.; TOKUDA, H.; NISHIRO, H.; PASTORE, F. Cancer chemopreveritive effects of a Brazilian folk medicine, Juca, on in vivo two-stage skin carcinogenesis. J. Ethnopharmacol., Amsterdam, v.81, n.1, p.135-137, 2002.

NAMIKOSHI, M.; NAKATA, H.; YAMADA, H.; NAGAI, M.; SAITOH, T. Homoisoflavonoids and related compounds. II. Isolation and absoluteconfigurations of 3,4-dihydroxylated homoisoflavans and Brazilins from Caesalpinia sappan L. Chem. Pharm. Bull., Tokyo, v.35, n.7, p.2761-2773, 1987a.

NAMIKOSHI, M.; NAKATA, H.; SAITOH, T. Homoisoflavonoids and relatedcompounds. I. Homoisoflavonoids from Caesalpinia sappan L. Phytochemistry, New York, v.26, n.6, p.1831-1833, 1987b.

NAMIKOSHI, M.; NAKATA, H.; NUNO, M.; OZAWA, T.; SAITOH, T. Homoisoflavonoids and related compounds. III. Phenolic constituents of Caesalpinia japonica Sieb et. Zucc. Chem. Pharm. Bull., Tokyo, v.35, n.9, p.3568-3575, 1987c.

NAMIKOSHI, M.; NAKATA, H.; SAITOH, T. Homoisoflavonoids and related compounds. V. A novel dibenzoxocin derivative from Caesalpinia sappan L. Chem. Pharm. Bull., Tokyo, v.35, n.9, p.3615-3619,1987d.

NIGAM, S.S. et al. Analysis of fixed oil from heart wood of $C$. sappan Linn. J. Inst. Chem. (India), Calcutta, v.50, n.2, p.35-36, 1977.

NOVEL, J.W. Medicinal plants of the eastern region of Madagascar. J. Ethnopharmacol., Amsterdam, v.55, n.2, p.119-126,1997.

OCETE, M.A.; GALVEZ, J.; CRESPO, M.E.; CRUZ, T.; GONZALES, M.; TORRES, M.I.; ZARZUELO, A. Effects of morin on an experimental model of acute colitis in rats. Pharmacology, Basel, v.57, n.5, p.261-270, 1998.

OGAWA, K.; AOKI, I.; SASHIDA,Y. Caesaljapin, a cassane diterpenoid from Caesalpinia decapetala var. japonica. Phytochemistry, New York, v.31, n.8, p.2897-2898, 1992. 
OGUCHI, R.K. et al. Does the photosynthetic light-acclimation need changes in leaf anatomy?. Plant Cell \& Environment, 26 (4): 505-509, April, 2003.

OH, S.R.; KIM, D.S.; LEE, I.S.; JUNG, K.Y.; LEE, J.J.; LEE, H.K. Anticomplementary activity of constituents from the heartwood of Caesalpinia sappan L. Planta Med., Stuttgart, v.64, n.5, p.456-458, 1998.

OLIVEIRA, F.; AKISUE, G. Microtécnica vegetal. In: Fundamentos de farmacobotânica. 2.ed. Rio de Janeiro: Atheneu, 1989. cap.1, p.25. (Série Farmácia-Bioquímica).

PARMAR, V.S.; SINGH, S.; JACOBSEN, J.P.; BOLL, P.M. Structure of a new homoisoflavanone from Caesalpinia pulcherrima. Acta Chem. Scand., Ser. B., Copenhagen, v.B41, n.4, p.267-270, 1987.

PATIL, A.D.; Freyer, A.J.; Webb, R.L.; Zuber, G.; Reichwein, R.; Bean, M.F.; Faucette, L.; Johnson, R.K. Pulcherrimins A-D, novel diterpene dibenzoates from Caesalpinia pulcherrima with selective activity against DNA repairdeficient yeast mutants. Tetrahedron, Amsterdam, v.53, n.5, p.1583-1592, 1997.

PETER, S.; Tinto, W.F.; McLean, S.; Reynolds, W.F.; Yu, M. Cassane diterpenes from Caesalpinia bonducella. Phytochemistry, New York, v.47, n.6, p.11531155, 1998.

PUURUNEN, J.; HUTTUNEN, P.; HIRVONEN, J. Is ethanol-induced damage of the gastric mucosa a hyperosmotic effect? Comparative studies on the effects of ethanol, some other hyperosmotic solutions and acetylsalicylic acid on rat gastric mucosa. Acta Pharmacol. Toxicol., Copenhagen, v.47, n.5, p.321$327,1981$.

RANG, H.P. e DALE, M.M.P. O Trato gastrointestinal. In: Farmacologia. Rio de Janeiro: Guanabara, 2001, p.305-317.

REATEGUI, G.R.; NAKASONE, R.H. Production of gallic acid from tannins extracted from Caesalpinia spinosa Kuntze (tara). Bol. Soc. Quim. Peru, Lima, v.54, n.1, p.12-19, 1988.

RIBEIRO, J.E.L.S et al. Flora da Reserva Ducke. Manus:INPA, p.382-395, 1999. 
ROBERTSON, K.R., LEE, Y. Jounal Arnould Arboretum, v.57, n.1, p.1-53, 1976.

ROENGSUMRAN, S.; LIMSUWANKESORN, S.; NGAMROJNAVANICH, N.; PETSOM, A.; CHAICHANTIPYUTH, C.; ISHIKAWA, T. Cassane diterpenoid from Caesalpinia major. Phytochemistry, New York, v.53, p.841-844, 2000.

ROESER, K.R. Mikrokosmos, Stuttgart, v.61, p.33-36, 1962.

SALIM, A.S. Removing oxygen-derived free radicals stimulates healing of ethanol induced erosive gastritis in rat. Digestion, Farmington, v.47, p.24-28, 1990.

SÁNCHEZ de MEDINA, F.L.; GALVEZ, J.; ROMERO, J.A.; ZARZUELO, A. Effect of quercitrin on acute and chronic experimental colitis in the rat. J. Pharmacol. Exp. Ther., Bethesda, v.278, n.2, p.771-779, 1996.

SANTOS, S.C.; MELLO, J.P.C. Taninos. In: SIMÕES, C.M.O.; SCHENKEL, E.P.; GOSMANN, G.; MELLO, J.C.P.; MENTZ, L.A.; PETROVICK, P.R., eds. Farmacognosia: da planta ao medicamento. Porto Alegre: UFSC; Porto Alegre: UFRGS, 1999. p.517-544.

SARTORI, N.T. Triagem de plantas medicinais popularmente utilizadas como anti-úlcera em Mato Grosso e avaliação do efeito anti-úlcera de fração diclorometânica (DMC2) de Calophyllum brasiliense Camb. (Guanadi). Cuiabá, 1997. 115p. Dissertação de Mestrado - Instituto de Saúde Coletiva Universidade Federal de Mato Grosso.

SASS, J.E. Botanical microtechnique. 2.ed. Ames: lowa State College Press, 1951.

SCHENKEL, E.P., GOSMAN, G., PETROVICK, P.R. Produtos de origem vegetal e o desenvolvimento de medicamentos. In: SIMÕES, C.M.O.; SCHENKEL, E.P.; GOSMANN, G.; MELLO, J.C.P.; MENTZ, L.A.; PETROVICK, P.R., eds. Farmacognosia: da planta ao medicamento. Porto Alegre: UFSC; Porto Alegre: UFRGS, 2003. p.291-320a.

SCHENKEL, E.P., GOSMANN, G., ATHAYDE, M.L. Saponinas. In: SIMÕES, C.M.O.; SCHENKEL, E.P.; GOSMANN, G.; MELLO, J.C.P.; MENTZ, L.A.; PETROVICK, P.R., eds. Farmacognosia: da planta ao medicamento. Porto Alegre: UFSC; Porto Alegre: UFRGS, 2003. p.597-622b. 
SHARMA, S.R.; DWIVEDI, S.K.; SWARUP, D. Hypoglycaemic, antihyperglycaemic and hypolipidemic activities of Caesalpinia bonducella seeds in rats. J. Ethnopharmacol., Amsterdam, v.58, n.1, p.39-44, 1997.

SILVA, C.C.S.S.; BARROS, A.M.D.; JORGE,L.F. Estudo farmacobotânico da espécie Caesalpinia ferrea Mart. (pau-ferro ou juca). Rev. Bras. Farm., v.78, n.2, p.26-28, 1997.

SRINIVAS, K.V.N.S.; RAO, Y.K.; MAHENDER, I.; DAS, B.; KRISHNA, K.V.S.R.; KISHORE, K.H.; MURTY, U.S.N. Flavonoids from Caesalpinia pulcherrima. Phytochemistry, New York, v.63, n.7, p.789-793, 2003.

STEVENS, K.R.; GALLO, M.A. Pratical considerations in the conduct of chronic toxicity studies. In: HAYES, W.A., ed. Principles and methods of toxicology. New York: Raven Press., 1982. p.53-57.

STOCKS, J.; GUTTERID, J.M.; SHARP, R.J.; DORMANDY, T.L. Assay using brain homogenate for measuring the antioxidant activity of biological fluids. Clin. Sci. Mol. Med., London, v.47, n.3, p.215-222, 1974.

SUZUKI, Y.; ISHIHARA, M.; SEGAMI, T.; ITO, M. Anti-ulcer effects of antioxidants, quercetin, $\alpha$-tocopherol, nifedipine and tetracycline in rats. Jpn. J. Pharmacol., Tokyo, v.78, n.4, p.435-441, 1998.

SZABO, S.; VATTAY, P. Experimental gastric and duodenal ulcers: advances in pathogenesis. Gastroenterol. Clin. North Am., Philadelphia, v.19, n.1, p.65, 1990.

TAKAGI, K.; OKABE, S.; SAZIKI, R. A new method for the production of chronic gastric ulcer in rats and the effect of several drugs on its healing. Jpn. J. Pharmacol., Tokyo, v.19, n.3, p.418-426, 1969.

TAKHTADZHIAN, A.L. Diversity and classification of flowering plants. Columbia University Press, New York, 1997, p. 67-107.

UEDA, H.; TACHIBANA, Y.; MORIYASU, M.; KAWANISHI, K.; ALVES, S.M. Aldose reductase inhibitors from the fruits of Caesalpinia ferrea Mart. Phytomedicine, Jena, v.8, n.5, p.377-381, 2001.

WAGNER,H.M., BLADT, S. and ZGAINSKI, E.M. Plant Drug Analysis. Berlim: Springer, 1996. 
YADAVA, R.N.; NIGAM, S.S. Constituents on the heartwood of C. sappan Lirnn. Chem. Pharm. Bull., Tokyo, v.13, n.2, p.87-88, 1987.

YANG, B.O.; KE, C.Q.; HE, Z.S.; Yang, Y.P.; Ye, Y. Brazilide A, a novel lactone with un unprecedented skeleton from Caesalpinia sappan. Tetrahedron Lett., Amsterdam, v.43, n.9, p.1731-1733, 2002.

YUTING,C. et al. Flavonoids as superoxide scavengers and antioxidants. Free Radical Biology \& Medicine, v.9, p. 19-21, 1990. 